Historic, Archive Document

Do not assume content reflects current scientific knowledge, policies, or practices. 



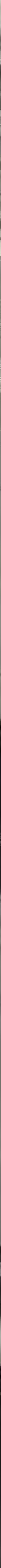




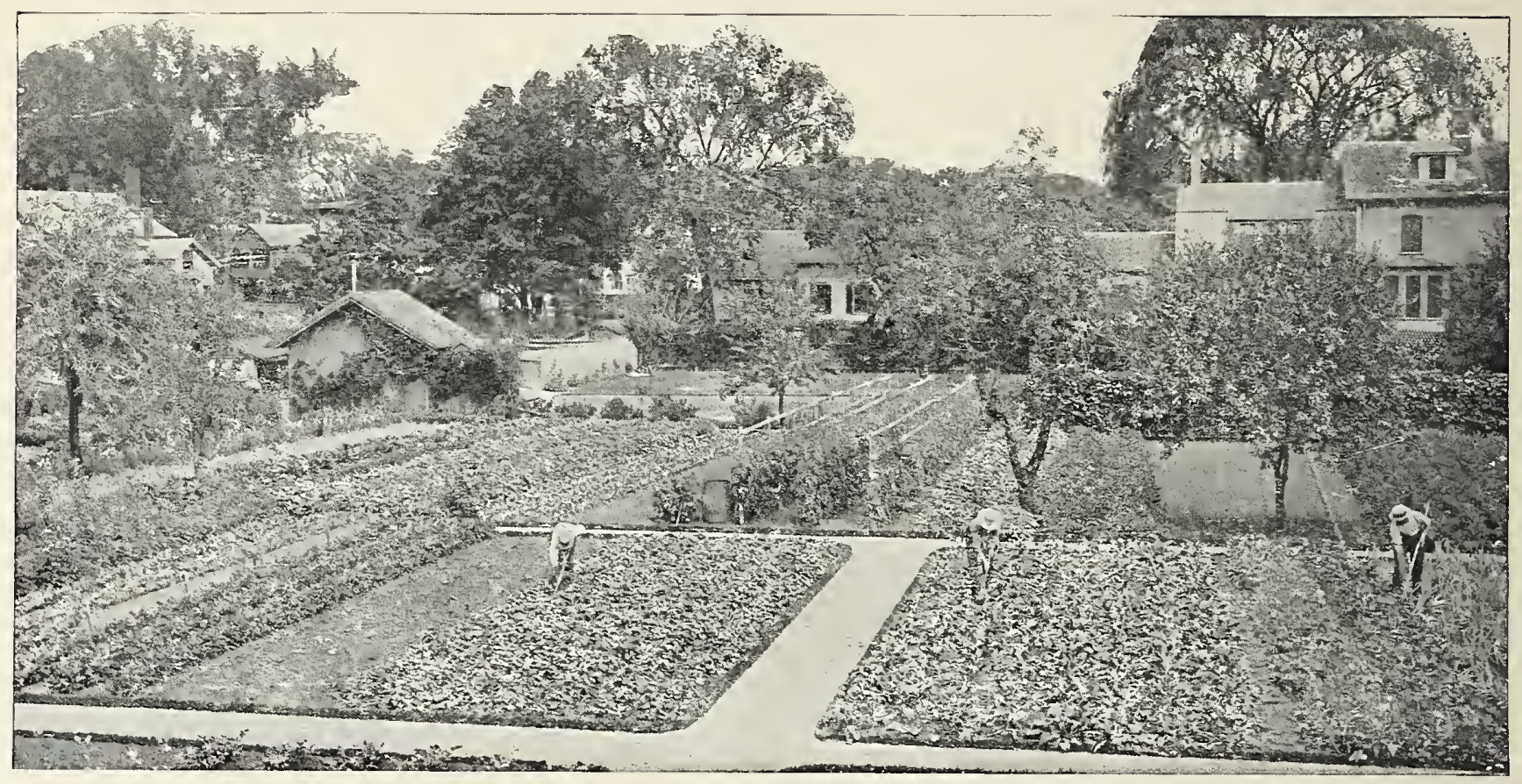

\section{Spring, 1921}

\section{Dear Reader:}

We wish to thank our customers for their many favors in the past, and again take great pleasure in handing you herewith our new Seed, Bulb and Tool Catalogue for the coming season.

In looking through the following pages there is no doubt that you will find many things you would like to try, and we trust you will not hesitate to send for them, no matter how few or how many.

It has always been our object not only to send out seeds of the highest germination, but also seeds that are true to name and which can be relied upon to produce the finest vegetables and the most beautiful flowers.

Trusting you will favor us with your valued orders, which will have our personal and most careful attention.

Yours very truly,

\section{Myrtle Ave. \\ M. H. BRUN.JES \& SONS, Brooklyn, N. Y.}

\section{Read Carefully Before Ordering}

HOW TO ORDER. We advise placing your order early. Please use order sheets found in the back part of the catalogue, carefully filling out blank spaces at top for shipping directions.

SEND CASH WITH THE ORDER. This can be done either in the forn of a Money Order, Bank Draft, Express Order or Registered Letter. Remittances scnt in any other way are entireiy at the sender's risk. Small amounts may be sent in postage stamps.

EXPRESS AND FREIGHT ORDERS. When orders are received to be shipped by express or freight, the purchaser must pay the charges.

\section{REGARDING PARCEL, POS'T}

Within the United States and Possessions-Alaska, Canal Zone, Guam, Hawaii, Porto Rico and the Philippines.

THE MAXIMUM WEIGET allowable to the 3rd zone is 70 pounds and to all other zones (4th to 8 th) it is 50 pounds.
THE SIZE OF PARCEL must not exceed 6 feet ( 72 inches) for combined length and largest girth.

SEEDS BY PARCEL POST. Orders for packets, ounces and quarter-pounds will be sent by parcel post, postage free, at prices given. If larger quantities are wanted, add postage at your zone rate.

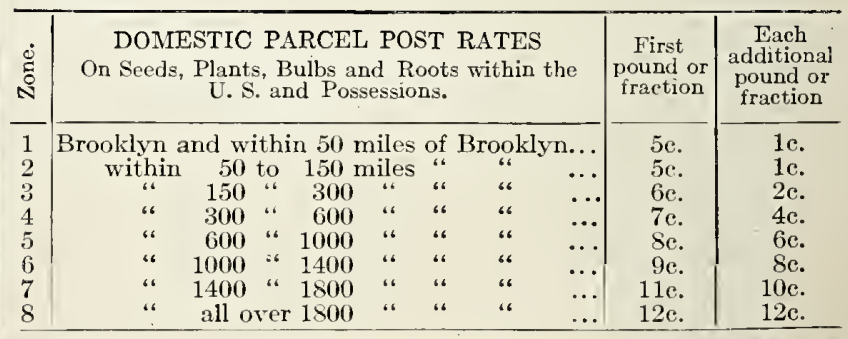

NON WARRANTY. M. H. Brunjes \& Sons give no warranty, express or implied, as to deseription, quality, productiveness or any other matter of any seeds, bulbs or plants they send out, and they will to be returned.-M. H. B. \& Sons. 


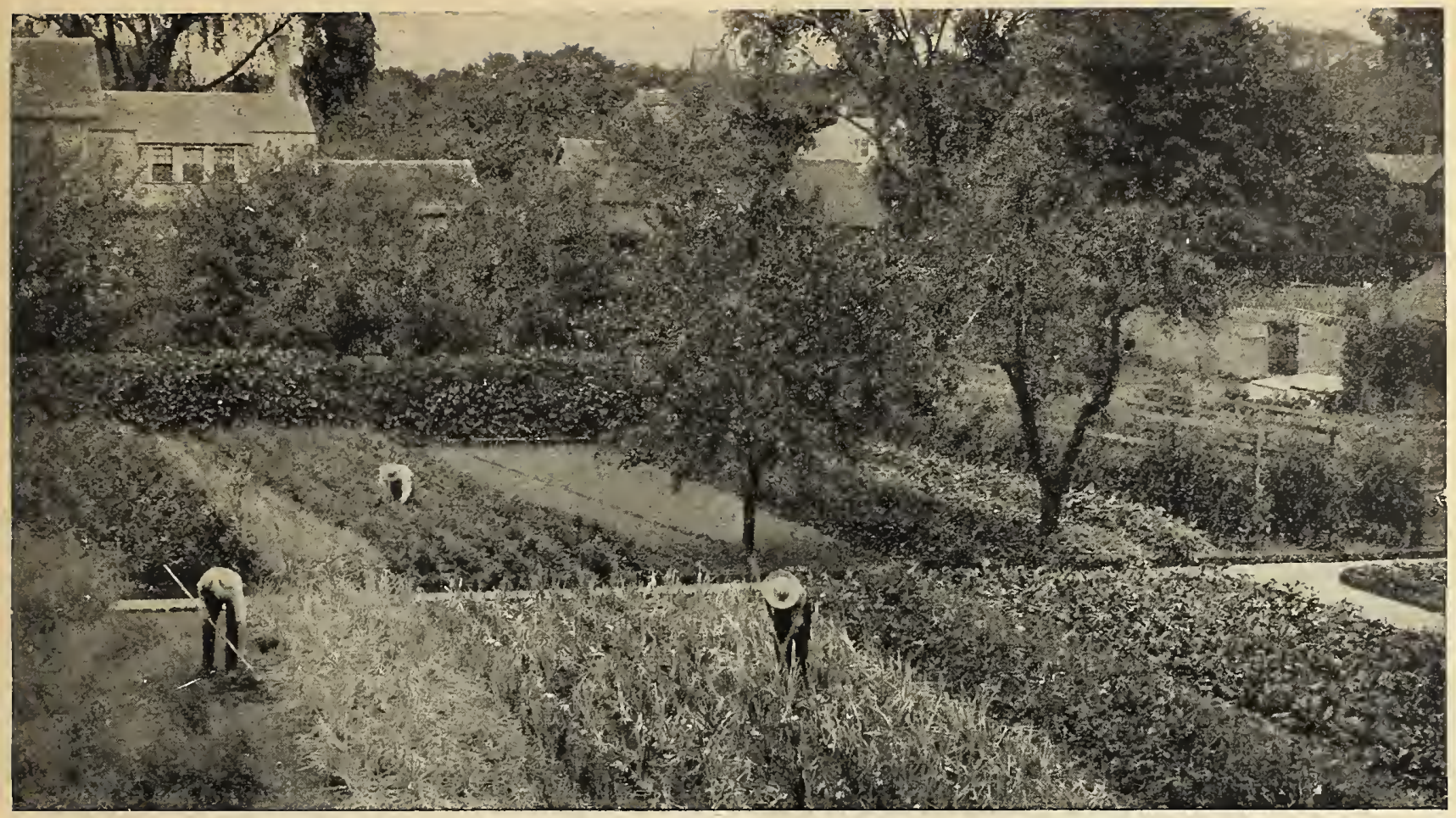

\section{H. BRUNJES \& SONS'}

\section{Reliable Vegetable Seeds}

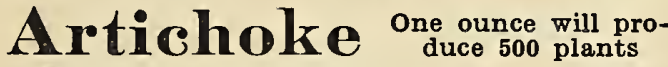

To secure globes the first year sow the seed in hotbeds during February, and in May transplant in rows three feet apart and two feet apart in the row, selecting a bed of deep, rich and rather moist soil. Seed may. also be sown outdoors in May, but will not mature until the second year. In winter protect the crowns with a covering of leaves or straw.

Large Globe. Heads light green, thick and fleshy. Per pkt. 10 cts., oz. $\$ 1.25$.

Jerusalem. Unlike the above, the roots when pickled are the edible portion of this variety, but it is mainly grown for feeding stock. Plant the tubers in rows four feet apart and

one foot apart in the row, cultivating same as potatoes. Five bushels will plant one acre. Large tubers, per qt. 25 cts., pk. $\$ 1.25$, bush. $\$ 4$.

\section{ASDaragus One ounce will sow about 50 feet of drill;}

Sow the seed outdoors about April or May in drills one foot apart and two inches deep. When well developed, plants should be thinned out to two inches apart and the following spring, or preferably when two years old, transplanted to permanent beds of sandy soil that has been thoroughly dug and well enriched with manure. Set plants twelve inches apart in trenches eighteen inches wide and after carefully spreading the roots cover to depth of four inches: and the second row three or four fcet from the first. Cultivate frequently and add a top dressing of well-rotted manure or wood-ashes in the fall. Cutting should not take place until roots are four years old.

Palmetto. An early sort with light green shoots of the finest quality. Pkt. 5 cts., oz. $10 \mathrm{cts} ., 1 / 4$ b. $20 \mathrm{cts}$., lb. $60 \mathrm{cts}$.

Conover's Colossal. One of the best for gcneral use. Large, tender stalks especially desirable for canning. Pkt. 5 cts., oz, $10 \mathrm{cts}$., 1/4l lb. $20 \mathrm{cts}$., lb. $60 \mathrm{cts}$.

\section{ASPARAGUS ROOTS}

$A$ bed twelve by thirty-two feet requires 100 roots

Results are obtained two years earlier by planting roots.

Palmetto. Strong two-year-old roots. 25 for 50 cts.; per $100 \$ 1.75$, per $1,000 \$ 15$.

Giant Argenteuil. Strong two-year-old roots. 25 for $50 \mathrm{cts}$., per $100 \$ 1.75$, per $1,000 \$ 15$.

NOTICE.-Our Asparagus Roots are extra large and we prefer to ship them by express at purchaser's expense. If wanted by parcel post, add postage at zone rate. 25 roots weigh $5 \mathrm{lbs}$.

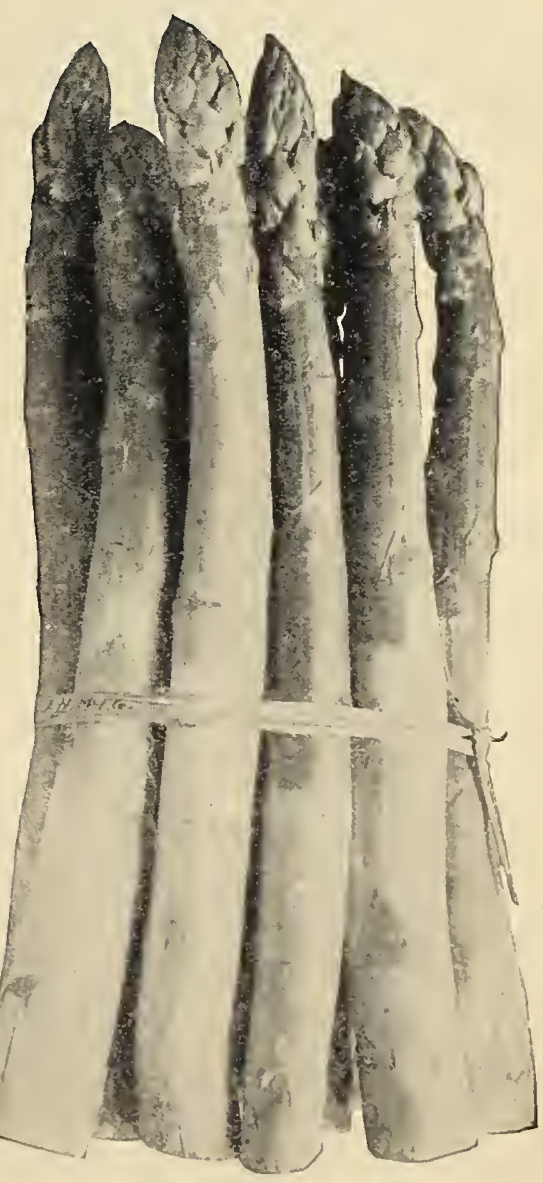

Asparagus, Palmetto 


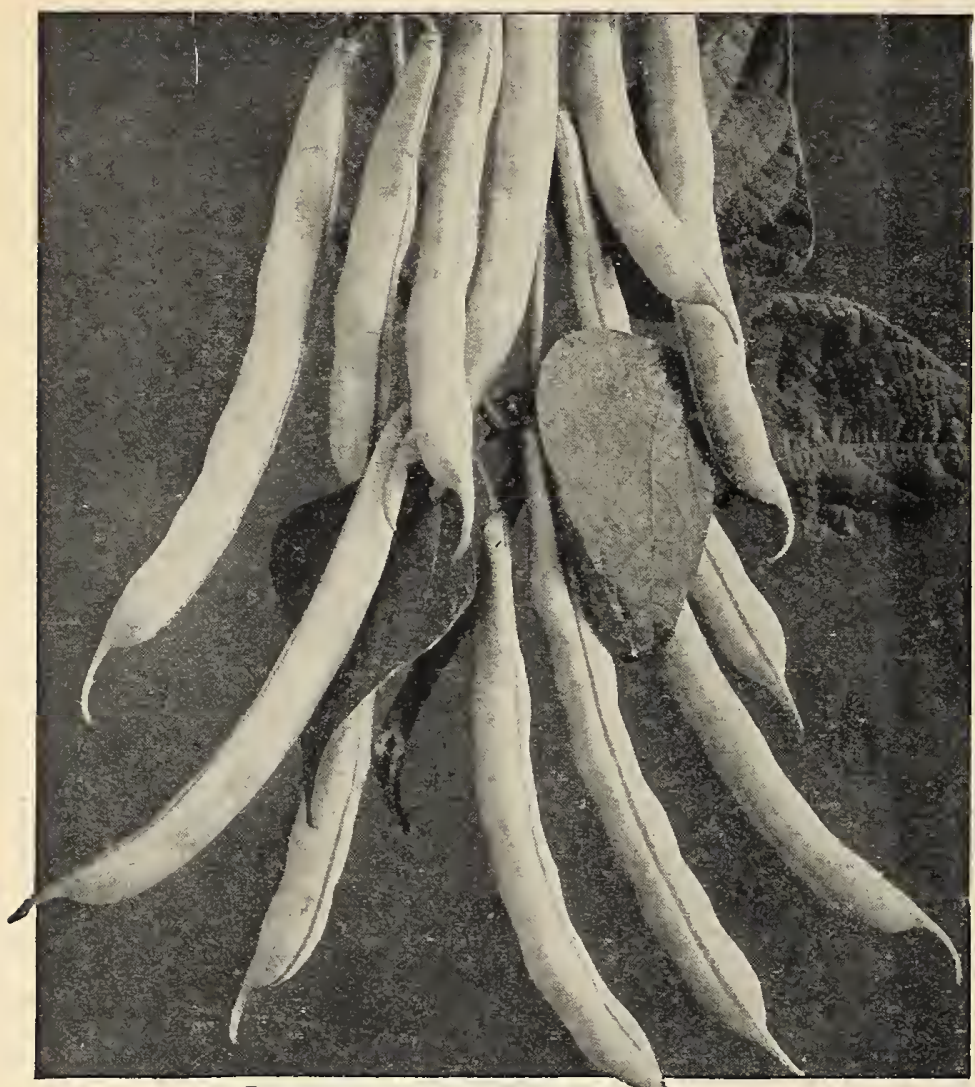

Beans, Refugee, or 1,000-to-1

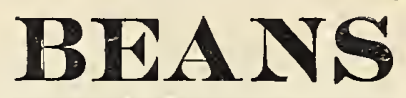

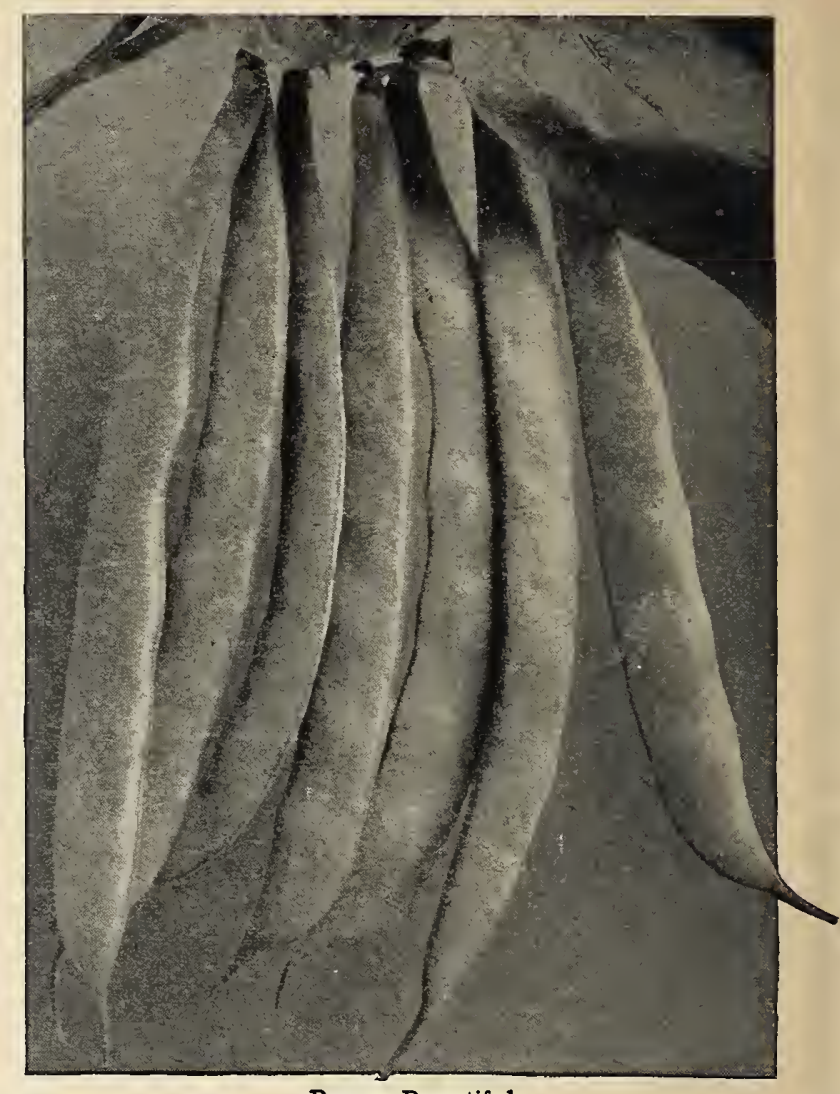

Beans, Bountiful

We have adopted the cental system in selling Beans and quote prices by weight instead of measure. One pound is equal to about a pint.

The seeds should not be planted before the ground becomes light and warm; in favorable seasons usually about May 1 . The soil should be rich and mellow, and the seeds scattered about 3 inches apart in drills 2 feet apart, and covered about 2 inches deep. Successive sowings made at intervals of about 2 weeks until August 15 will give a plentiful supply of Beans all season. One pound will sow 100 feet of drill: 60 pounds will sow an acre.

\section{BEANS, BUSH, GREEN-PODDED}

Bountiful. For an early, flat, Green-podded Bush Bean of the Bountiful. highest quality, try Bountiful. A valuable sort, equally good for market or private garden; bears continuously for several weeks. The Beans are uniform in size, flat, solid, stringless and retain their tenderness even when past maturity. $\frac{1}{2} \mathrm{lb} .20 \mathrm{cts}$., lb. 35 cts., 2 lbs. 65 cts., 10 lbs. $\$ 2.75$.

Black Valentine. Has very long, handsome, round pods, and being immensely productive this variety becomes one of the most profitable for the market-gardener. It is very early, but cannot compare with the best in quality. $\frac{1}{2} \mathrm{lb} .20$ cts., lb. 35 cts., 2 lbs, 65 ets., 10 lbs. $\$ 2.75$.

Dwarf Horticultural. A standard variety used extensively for shelling. When fully matured, the large, flat Beans are yellow, splashed with crimson. $\frac{1}{2}$ lb. $20 \mathrm{c}$., lb. $35 \mathrm{c},, 2 \mathrm{lbs} .65 \mathrm{c} ., 10 \mathrm{lbs} . \$ 2.75$.

Earliest Red Valentine. One of the most popular early all section Beans, and largely grown in tendections. The pods, abound, tender and of the finest flavor. Plants of erect growth, about 18 inches high and very heavy yielders. It will prove a fine variety in the home-garden, and a reliable and profitable Bean for the marketgardener. $\frac{1}{2} \mathrm{lb} .20 \mathrm{cts}$., lb. 35 cts., 2 lbs. 65 cts., 10 lbs. $\$ 2.75$.

Extra-Early Refugee. Matures two weeks earlier than Refugee, or 1,000-to-1. The plant grows similar to the Refugee, but the round-podded, light green Beans are somewhat smaller. $\frac{1}{2} \mathrm{lb} .20 \mathrm{cts}$., lb. 35 cts., 2 lbs. 65 cts., 10 lbs. $\$ 2.75$.

White Navy, or Boston Pea. Yields a large quantity of white Shell Beans, which are used for baking. $\frac{1}{2} l \mathrm{lb} .15 \mathrm{cts}$., lb. 30 cts., 2 lbs. 55 cts., 10 lbs. $\$ 2.50$.
Full Measure. A new, round-podded Bush Bean of the highest quality, maturing a short time later than StringThe pods are of handsome appearance, often exceed 5 inches in length, and are very meaty and free from strings. $\frac{1}{2}$ lb. 20 cts., lb. 35 cts., 2 lbs. 65 cts., 10 lbs. $\$ 2.75$.

Giant Stringless Green-Pod. The round, dark green pods, giant in size, are absolutely and unsurpassed in tenderness. For growing in the garden, to supply the home table, there are few that will give better satisfaction than Giant Stringless Green-Pod. $\frac{1}{2} \mathrm{lb} .20 \mathrm{cts}$., lb. 35 cts., 2 lbs. 65 cts., 10 lbs. $\$ 2.75$.

Long Six Weeks. Valuable on account of its extra earliness and productiveness. The pods are long and flat, and of good quality as long as they are tender. $\frac{1}{2}$ lb. 20 cts., lb. 35 cts., 2 lbs. 65 ets., 10 lbs. $\$ 2.75$.

Refugee, or 1,000-to-1. Although it will give equally good has become a favorite for sowing during July and used in the fall for pickling. The vines are rather large, immensely productive, bearing round, straight pods of uniform size, light-colored and of the best quality. A very reliable late variety. $\frac{1}{2} l \mathrm{lb} .20 \mathrm{cts}$., lb. $35 \mathrm{cts}$., 2 lbs. 65 cts., 10 lbs. $\$ 2.75$.

Stringless Green-Pod. An ideal variety, the pods of which are round, slightly curved and exceedingly tender. They are from 5 to 6 inches in length, rich green in color and are ready for picking a few days earlier than Giant Stringless Green-Pod. The vines are very productive. $\frac{1}{2} \mathrm{lb}$. $20 \mathrm{c}$., lb. $35 \mathrm{c}$., 2 lbs. $65 \mathrm{c}$., $10 \mathrm{lbs}$. $\$ 2.75$. 


\section{BEANS, BUSH, WAX-PODDED}

\section{IF BY PARCEL POST, ADD POSTAGE AT ZONE RATE}

New Kidney Wax. An attractive Wax Bean resembling Wardwell's Kidney Wax but broad; brittle, stringless and of high quality. $\frac{1}{2}$ lb. $20 \mathrm{c}$., lb. $35 \mathrm{c}$., 2 lbs. $70 \mathrm{c}$, $10 \mathrm{lbs}$. $\$ 3.25$.

Davis White Kidney Wax. Pods remarkably long, straight, and handsome; waxy white; enormously productive; seed white. $\frac{1}{2} \mathrm{lb} .20 \mathrm{cts}$., lb. 35 cts., 2 lbs. 70 cts., 10 lbs. $\$ 3.25$.

Hodson Wax. In growth of vine and productiveness this variety exceeds any other Wax-podded Bean. The long, flat pods, slightly curved, are of handsome appearance and usually free from rust. $\frac{1}{2} l$ b. 20 cts., lb. 35 cts., 2 lbs. 70 cts., 10 lbs. $\$ 3.25$.

Improved Golden Wax. Small plants of erect growth, bearing of excellent quality. An early and reliable variety recommended for home use. $\frac{1}{2}$ lb. 20 cts., lb. 35 cts., 2 lbs. 70 cts., 10 lbs. $\$ 3.25$.

Pencil-Pod Black Wax. This is an exceptionally fine sort like pods are round, slender, entirely free from strings, brittle and of a beautiful yellow; medium early and equal to the best in quality. $\frac{1}{2}$ lb. 20 cts., lb. 35 cts., 2 lbs. 70 cts., 10 lbs. $\$ 3.25$.

Prolific Black Wax. A selected strain, yielding round, tender Beans of medium size and superior quality; somewhat shorter but thicker than Pencil-Pod Black Wax. $\frac{1}{2} 1 \mathrm{lb} .20$ cts., lb. 35 cts., 2 lbs. 70 cts., 10 lbs. $\$ 3.25$.

Stringless Refugee Wax. Popular for either early or late planting. Plants are large, spreading and heavy yielders of round, fleshypodded Beans. $\frac{1}{2}$ lb. 20 cts., lb. 35 cts., 2 lbs. 70 cts., 10 lbs. $\$ 3.25$.

Sure-Crop Stringless Wax. The plants of this new dwarf, vigorous, and very productive.. Long, flat, rich yellow pods of excellent quality which are quite thick and withstand unfavorable

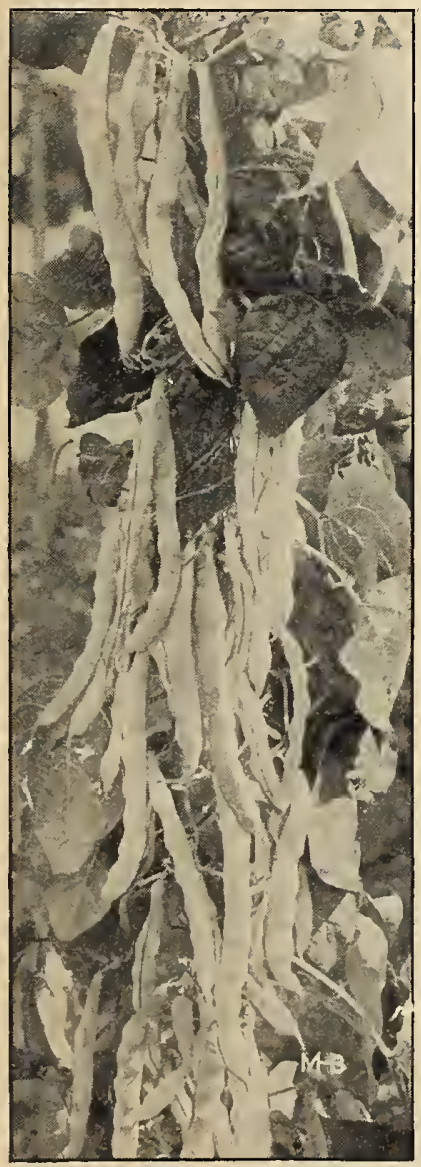

Beans, Old Homestead weather remarkably well. Ib. 20 cts., lb. 35 cts., 2 lbs. 70 cts., 10 lbs. $\$ 3.25$.

Wardwell's Kidney Wax. The pods of this vainches long, straight, flat and solid. It is medium early, maturing a little later than Improved Golden Wax; very

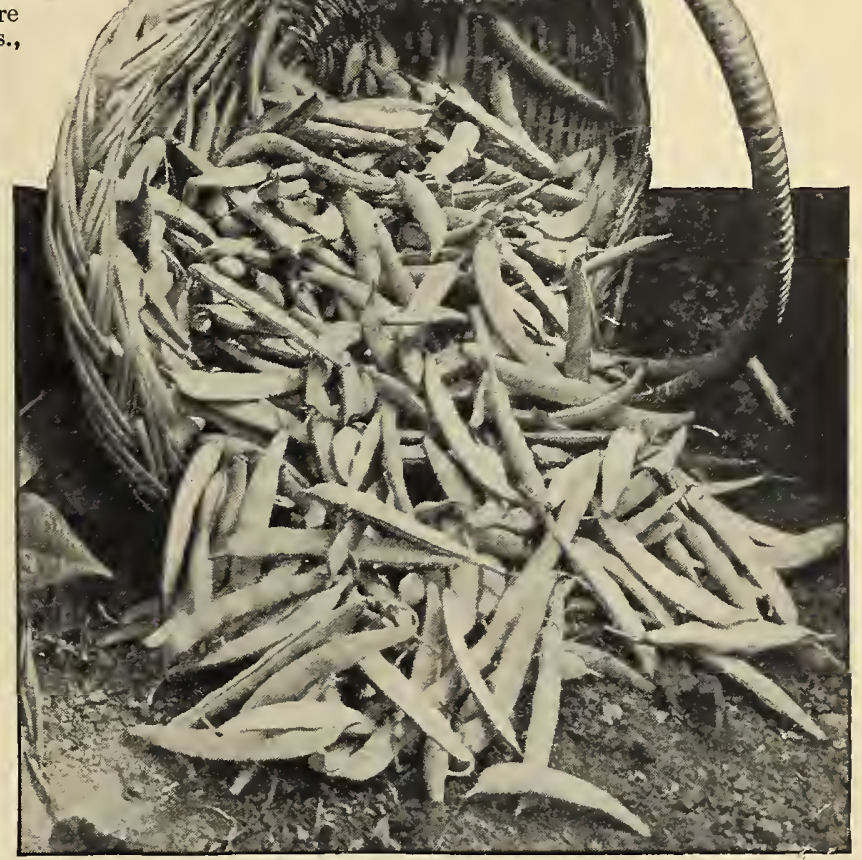

Beans, Wardwell's Kidney Wax productive and largely grown in all sections. $\frac{1}{2}$ lb. 20 cts., lb. 35 cts., 2 lbs. 70 cts., 10 lbs. $\$ 3.25$.

\section{Beans, Pole or Running}

One pound will plant 100 hills

\section{GREEN- AND WAX-PODDED}

As Pole Beans, especially the Limas, are more sensitive to cold, they should not be planted until warm weather, about May 15. For best results poles 8 to 10 feet long should be set 4 feet apart each way before planting. Plant five or six seeds, 2 inches deep, around each pole, and after the plants arc well started, thin out, leaving but three or four of the strongest. The bearing season of the Pole varieties will be found to be longer and the pods considerably larger than those of the Bush sorts.

Early Golden Cluster Wax. One of the best Wax-podded Pole Beans. The pods, borne in long time. $\frac{1}{2} \mathrm{lb} .20 \mathrm{cts}, \mathrm{lb} .35 \mathrm{cts} ., 2 \mathrm{lbs} .70 \mathrm{cts}$., $10 \mathrm{lbs} . \$ 3.25$.

Kentucky Wonder Wax. Everyone should try some of this fine Wax-podded Pole Bean. Like broader than the strong, vigorous growth, and bear early and continuously. $\frac{1}{2} \mathrm{lb} .20 \mathrm{c} ., 1 \mathrm{~b} .35 \mathrm{c} ., 2 \mathrm{lbs} .70 \mathrm{c} ., 10 \mathrm{lbs}$. $\$ 3.25$. Lazy Wife. A desirable variety of late maturity, having broad, flat, fleshy pods of light green and excellent quality. It may also be used as a Shell Bean, each pod containing six to eight white Beans which are almost as broad as long. $\frac{1}{2} \mathrm{lb} .20$ cts., lb. 35 cts., 2 lbs. 70 cts., 10 lbs. $\$ 3.25$.

Old Homestead, or Kentucky Wonder. This is decidedly the best of all Green-podded Old Homestead, or Kentucky Wonder. Pole Beans. The vines are of good climbing habit and heavy yielders of long, almost round pods, 8 to 10 inches in length, of the very best quality. An early and well-recommended sort for the home-garden. $\frac{1}{2} \mathrm{lb} .20 \mathrm{cts}$., 1 b. 35 cts., 2 lbs. 70 cts., $10 \mathrm{lbs}$. \$3.25. Searlet Runner. Generally grown as an ornamental climber, with bright scarlet flowers, but the Beans may also be used in the rreen state. $\frac{1}{2} \mathrm{lb}, 20$ ets. $1 \mathrm{~b}, 35 \mathrm{cts}, 2 \mathrm{lbs}, 70 \mathrm{cts}, 10 \mathrm{lbs}, \$ 3.25$.

Yard-Long. The pods measure from $1 \frac{1}{2}$ to 2 feet in length, are round and thick as a pencil; tender and of splendid flavor; seed small. Pkt. 10 cts. 


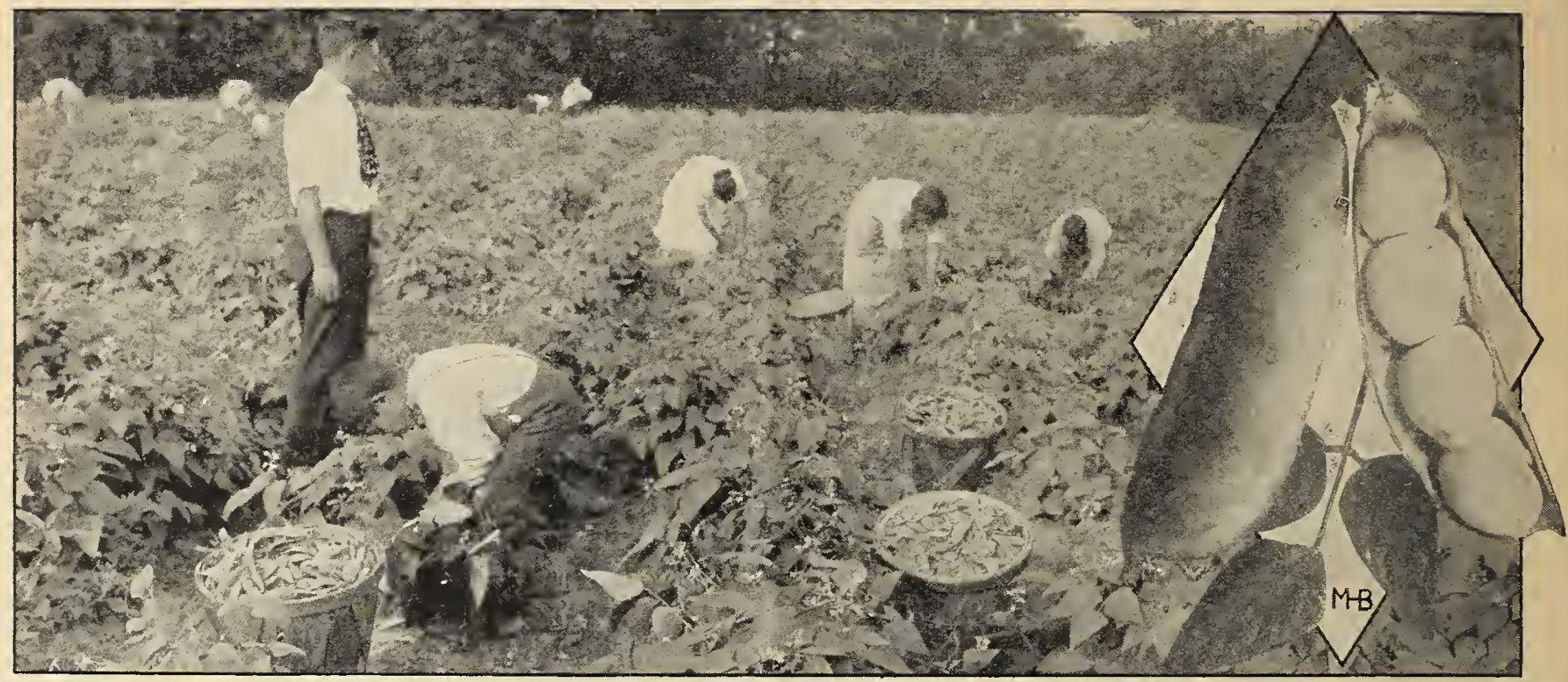

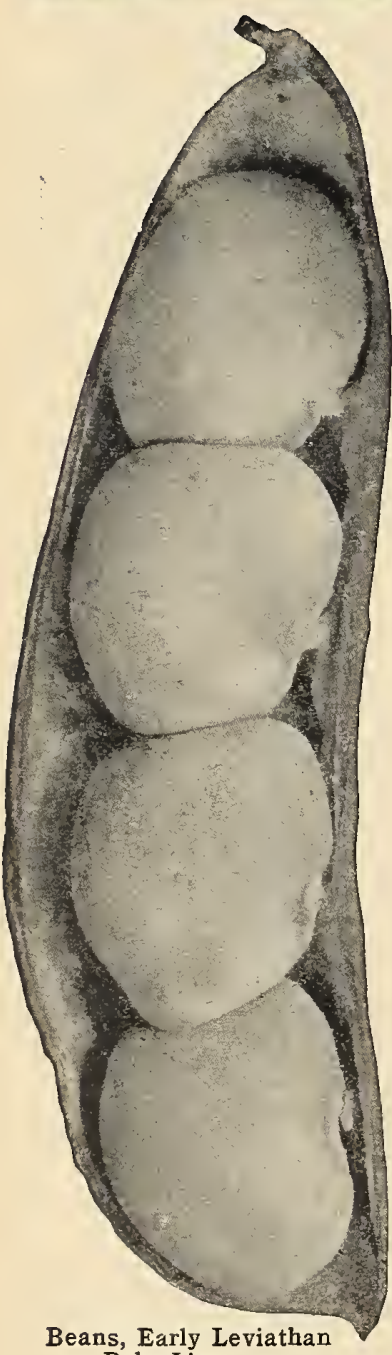
Pole Lima

\section{Beans, Bush Lima}

IF BY PARCEL POST, ADD POSTAGE AT ZONE RATES

Bush Limas should not be planted before the soil becomes warm and dry, usually about May 15. Plant in drills 2 feet apart and 13 inches apart in the row, about 2 inches deep.

Fordhook Bush Lima. The pods of this wonderful Bush Lima are not only double the size of the (nell-known Dreer's or Kumerle, but are thicker and produced in greater abundance from 4 to 6 days earlier. Each pod contains on an average four extra-large beans of delicious fla
The plants form erect bushes 20 to 30 inches high. $\frac{1}{2}$ lb. 20 cts., lb. 40 cts., 2 lbs. 75 cts., 10 lbs. $\$ 3.50$.

Burpee's Improved Bush Lima. This is the finest Bush Lima that has ever been introduced. 作 beans (more containing five than three) which are not only larger than those of the old variety, but are nearly twice as thick. In quality it is of the best. The bushes when fully grown measure $2 \frac{1}{2}$ feet in height and 24 inches across the top. It is about one week earlier than Burpee's Bush Lima. $\frac{1}{2} \mathrm{lb} .20$ cts., lb. 40 cts., 2 lbs. 75 cts., 10 lbs. $\$ 3.50$.

Burpee's Bush Lima. Plants vary from 18 to 24 inches in height, somewhat spreading and yielding long, flat pods, about 4 inches long, containing 3 or 4 beans of delicious flavor. $\frac{1}{2} \mathrm{lb} .20$ cts., lb. 40 cts., 2 lbs. 75 cts., 10 lbs. $\$ 3.50$.

\section{BEANS, ENGLISH or BROAD}

Broad Windsor. A distinct variety that requires early planting, preferably the latter part of March or Broad Windsor. early in April, to obtain best results. The beans should be planted in rows 3 feet apart, dropping the seeds 6 inches apart in the row and 2 to 3 inches deep. $\frac{1}{2}$ lb. 20 cts., lb. 40 cts., 2 lbs. 75 cts.

\section{Beans, Pole Lima $\begin{gathered}\text { One pound will plant } 50 \text { hills } \\ \text { For culture, se ofter role beans }\end{gathered}$}

Early Leviathan. The earliest of all Pole Limas and therefore one of the most reliable, either for the beans, unsurpassed in flavor, and are borne in large clusters continuously until late in the season. $\frac{1}{2} \mathrm{lb}$. $20 \mathrm{cts}$., lb. 35 cts., 2 lbs. 70 cts., 10 lbs. $\$ 3.25$.

Ideal. One of the newer introductions, somewhat similar, but superior, to the King of the Garden Lima. It Ideal. is a most excellent sort and certain to become popular when fully known. The straight, flat pods, uniform in size, are fully 6 to 8 inches in length, handsome, attractive, deep green in color and borne continuously until frost. $\frac{1}{2}$ lb. 20 cts., lb. 35 cts., 2 lbs. 70 cts., 10 lbs. $\$ 3.25$.

Ford's Mammoth-Podded. Where size of pod is the first consideration, this variety leads the list. Vines are unusually vigorous, enormously productive and of good climbing habit, while the pods, giant in size, are well filled with delicious beans. $\frac{1}{2}$ lb. 20 cts., lb. 35 cts., 2 lbs. 70 cts., 10 lbs. $\$ 3.25$.

Challenger Lima. This is today and always has been a favorite market sort; thick-podded, a good-yielder and matures early. $\frac{1}{2}$ lb. 20 cts., lb. 35 cts., 2 lbs. 70 cts., 10 lbs. $\$ 3.25$.

Dreer's Improved Lima. A fine, early variety, very productive and of superior quality. Pods very thick, about 4 to 5 inches in length and generally contain about 4 to 5 seeds. $\frac{1}{2} \mathrm{lb} .20$ cts., lb. 35 cts., 2 lbs. 70 cts., 10 lbs. $\$ 3.25$

Large White Lima. Vines dark green, of vigorous growth and good climbing habit. Its large, flat, tender beans of superb quality make this variety especially desirable for home use. $\frac{1}{2} \mathrm{lb} .20 \mathrm{cts}$., lb. $35 \mathrm{cts} ., 2 \mathrm{lbs}$. 70 cts., 10 lbs. $\$ 3.25$.

Carpinteria. The vines of this new Pole Lima are of strong, vigorous growth and yield many fine pods Carpinteria. which contain on an average four large, thick beans. The beans have a very thin skin, cook exceedingly tender and are of the most delicious flavor. Distinct in having a greenish tint, an indication of the finest quality, and make a fine appearance when cooked. $\frac{1}{2} \mathrm{lb} .20 \mathrm{cts}$., lb. 35 cts., 2 lbs. 70 cts., 10 lbs. $\$ 3.25$. 


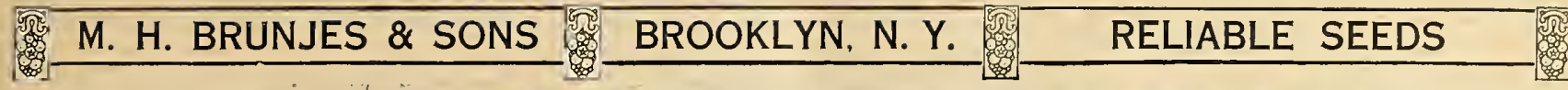

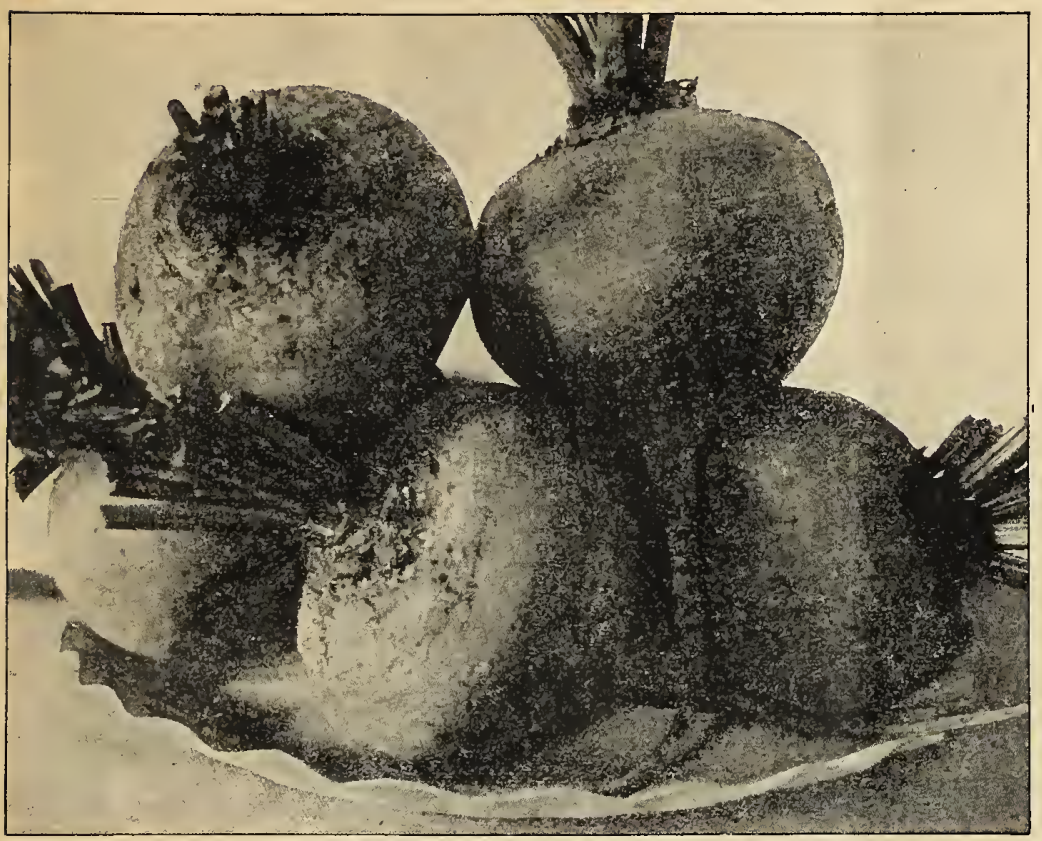

Beets, Edmand's Early Blood Turnip

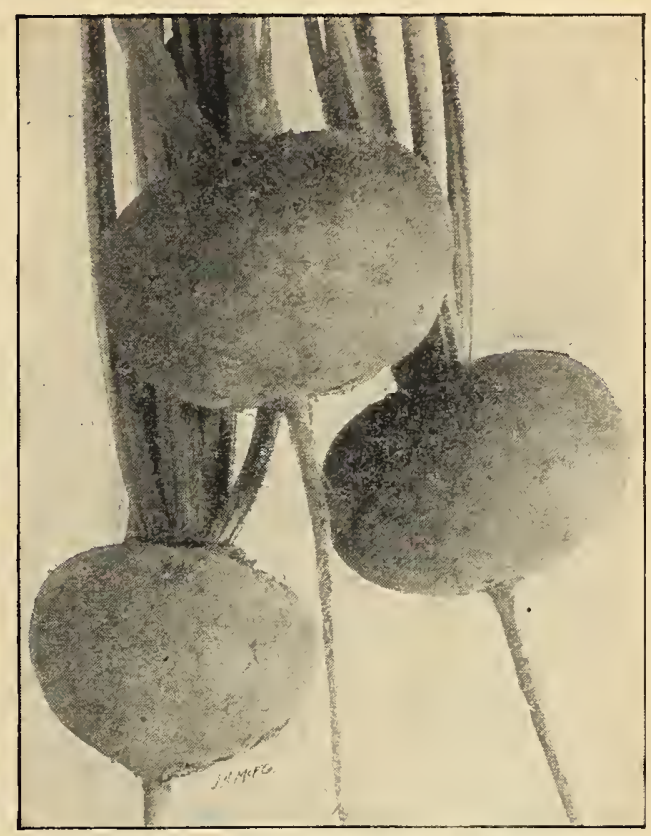

Beets, Crosby's Extra-Early Egyptian BEETS

One ounce will sow 50 feet of drill; 6 pounds for an acre

Best results are obtained by using a light soil that has been well enriched with manure. Sow in drills 1 foot apart and 1 ineh deep, as soon as the ground is in workable condition, and for suceession every two weeks until August. When the plants are well advanced thin out to 4 or 5 inehes apart. A liberal sowing should always be made during July for a winter erop.

Crosby's Extra-Early Egyptian. An improved strain of the well-known and very popular Early Egyptian, and, like ihat what flattened; flesh bright vermilion-red and in quality unsurpassed for flavor and fine grain. Pkt. 5 ets., oz. 15 ets., $\frac{1}{4}$ lb. 40 ets., lb. $\$ 1.25$.

Crimson Globe. This is one of the finest Beets yet introdueed. The roots are of medium size, and handsome appearance, round, with a elean, smooth surface. Pkt. 5 cts., oz. 15 cts., $\frac{1}{4} \mathrm{lb} .40$ cts., lb. $\$ 1.25$.

Detroit Dark Red Turnip. This variety cannot be too highly recomconded. It is not only one of the best for the market and home-garden, but is equally valuable for either early or late sowing. The root is globular in shape, very smooth, of a blood-red color and uniform size. Pkt. 5 ets., oz. 15 cts., $\frac{1}{4}$ lb. 40 cts., lb. $\$ 1.25$.

Dewing's Early Blood Turnip. Owing to its large tops and fine keeping qualities this Beet is largely used for late sowing. The fiesh of the dark red, turnip-shaped roots is of good color and fine quality. Pkt. 5 cts., oz. 15 cts., ${ }_{1}^{1} 1 \mathrm{lb} .40$ cts., lb. $\$ 1.25$

Early Egyptian. A favorite for sowing early in the frames and for the arst erop outdoors. It has small, deep green leaves, the home-garden. The flesh is of the darkest eolor, very sweet and tender. Pkt. 5 cts., oz. 15 cts., $\frac{1}{2}$ lb. 40 cts., Ib. $\$ 1.25$

Early Model. An extremely early Beet of deep blood-red eolor, with rather short tops and very smooth, globe-shaped roots. It is one of the sweetest and tenderest in our list and valuable both for the frames and outside sowing. Pkt. 5 cts., oz. 15 cts., $\frac{1}{2}$ lb. 40 cts., lb. $\$ 1.25$.

Early Wonder. A very fine selection of deep blood-red Beet particularly recomsmall tops and mended for early sowing. The roots are globular in shape, have time. Market-gardeners will find Early Wonder a valuable variety to sow as an early bunch Beet. Pkt. 5 ets., oz. 15 ets., $\frac{1}{4} \mathrm{lb} .40$ cts., lb. $\$ 1.25$.

Edmand's Early Blood Turnip. A splendid Beet for late planting. The roots are of medium size, almost round but slightly flattened, of good color, with sweet, juicy flesh; excellent keeper. Pkt. 5 cts., oz. 15 cts., $\frac{1}{4}$ lb. 40 cts., Ib. $\$ 1.25$.

Improved Blood Turnip. A remarkably fine Beet for either early or the darkest color and highest quality lb. $\$ 1.25$.

Long Smooth Blood. An excellent sort whieh keeps well during the winter. The roots, when fully matured, are almost a foot in length, half forming above the ground; very smooth, with few side roots. The skin and flesh are both of the darkest red color. Pkt. 5 ets., oz. 15 cts., 11 lb. 40 ets., lb. \$1.25.

Swiss Chard. For deseription and price, see page 25.

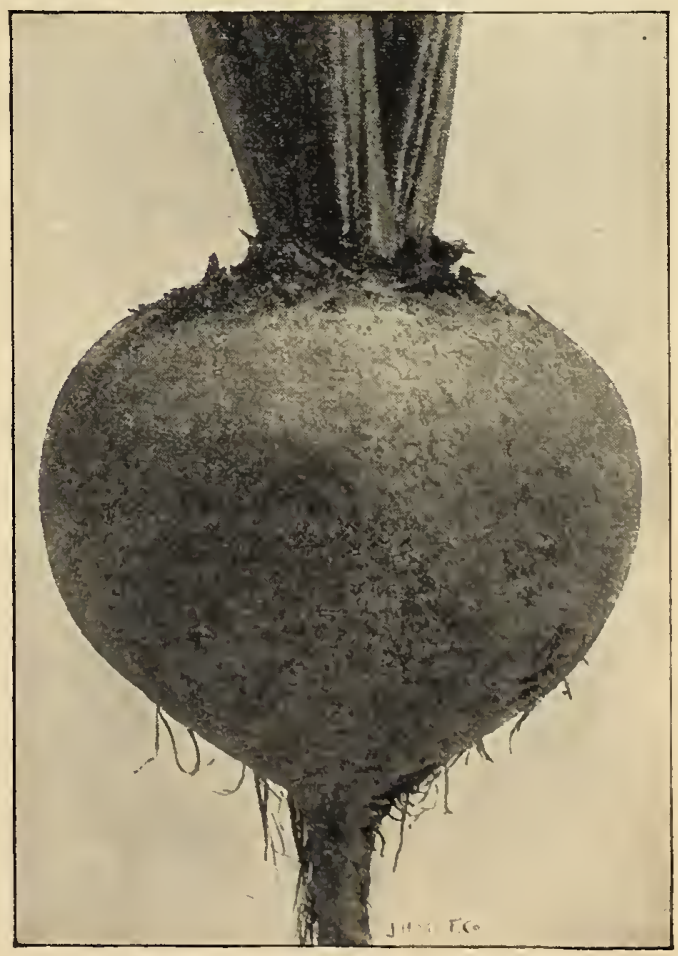

Beet, Dewing's Early Blood Turnip 


\section{MANGEL-WURZEL}

Six pounds will sow an acre

Mangel-Wurzels are invaluable for feeding stock. In May or June sow the seed in drills not less than 2 feet apart and later thin out so the plants stand from 6 to 8 inches apart in the row. As they grow to an immense size, a deep soil that has been well enriched with stable manure is best suited for their culture.

Mammoth Long Red. A standard sort yielding long, thick, straight roots, having light red-colored flesh. It is prized for feeding stock during the winter and is undoubtedly the most largely grown of all Mangels. Oz. 10 cts., $1 / 4 \mathrm{lb}$. 30 cts., lb. $\$ 1$.

Yellow Globe. Large, globe-shaped; flesh white, tinged yellow. Suited to light or shallow soils. Oz. $10 \mathrm{cts}$., $1 / 4$ lb. 30 cts., lb. $\$ 1$.

Golden Tankard. One of the best yellow varieties, having small tops and smooth, oval-shaped roots. Flesh yellow zoned with white. Very productive and a good keeper. Oz. 10 cts., $1 / 4$ lb. 30 cts., lb. $\$ 1$.

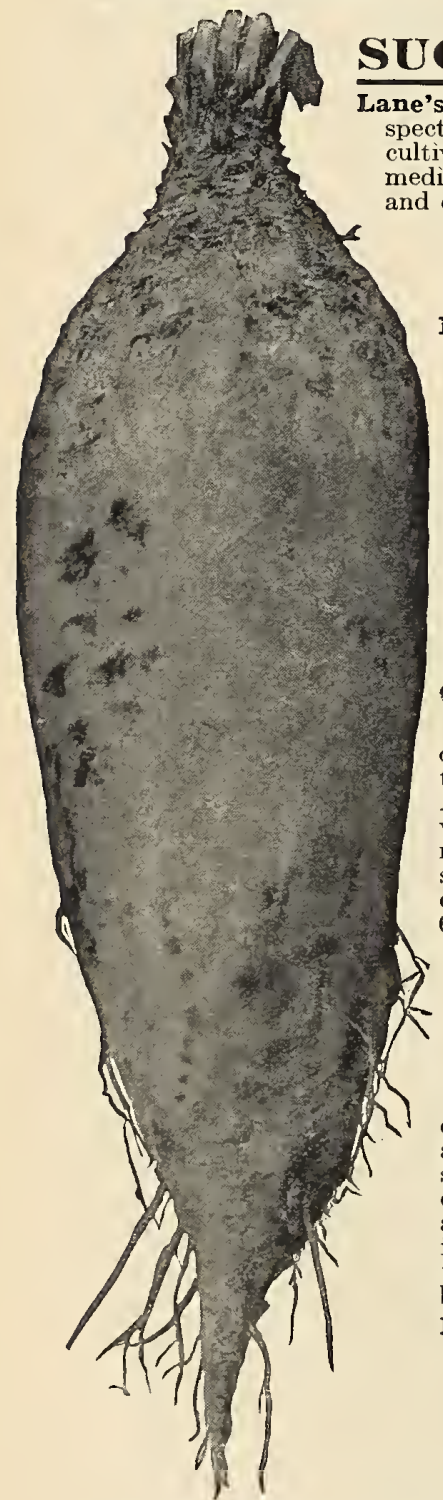

Mangel-Wurzel, Mammoth Long Red

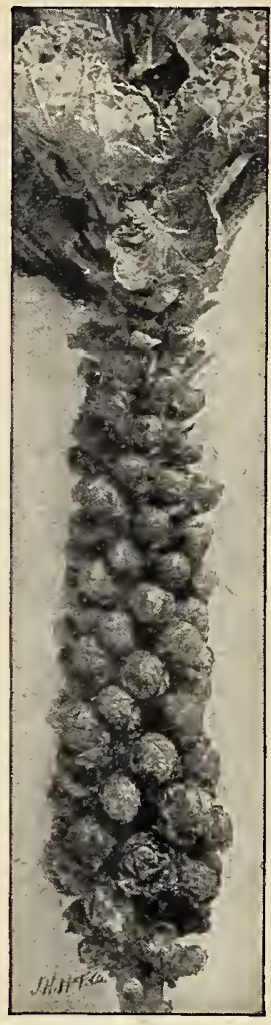

Brussels Sprouts, Long Island Improved

\section{BRUSSELS SPROUTS}

One ounce will produce 3,000 plants

For early fall use sow seed outdoors in May and during July set plants every 18 inches in rows 2 feet apart. Later sowings may be made in June. The sprouts are far superior in flavor to either cabbage or kale, especially after a hard frost, and from June sowings will be ready for use during the early part of October. Between one and two quarts is the average yield of one plant.

Brunjes' Long Island Improved. The stems riety grow about 2 feet high and are covered with cabbage-like sprouts about $1 \frac{1}{2}$ inches in diameter.

Unsurpassed in quality. A selected strain of unusual merit and well worth a trial in every garden. Pkt. $10 \mathrm{cts}$., oz. $30 \mathrm{cts}$., $\frac{1}{4} \mathrm{lb} .90 \mathrm{cts}$., lb. $\$ 3$.

Improved Dwarf. Early and of dwarf habit, but the heads are large, sweet and tender. Pkt. 5 cts., oz. 25 cts., $\frac{1}{4}$ lb. 75 cts., lb. $\$ 2.50$.

BORECOLE. See Kale.

\section{CHERVIL}

\section{One ounce will sow 100 feet of drill}

The Chervil resembles the parsley in appearance, and is highly esteemed for flavoring and garnishing dishes of meats and vegetables. Seed may be sown early in spring, but when the plants are quite large they should be transplanted about 10 inches apart.

Curled. The leaves when young are superior to parsley and prized for their delicious flavor. Usually in about 10 weeks after the seed is sown the leaves are ready for use. They are densely curled and not so large as parsley. Pkt. 5 cts., oz. 15 cts., $\frac{1}{4} \mathrm{lb} .40 \mathrm{cts}$. lb. $\$ 1.25$.

\section{CHICORY} immense cropper, of ten yielding from 15 to 18 tons to the acre. Oz. 15 cts., $\frac{1}{4} \mathrm{lb}$. 40 cts., lb. $\$ 1.25$.

\section{BORAGE}

One ounce will sow 50 feet of drill

The leaves have a cucumber-like odor, and are used as a salad. Sow the seed in drills 1 foot apart from April until August and when well advanced thin out to 3 inches in the row. As it soon runs to seed, make sowings every two weeks for a succession. Pkt. 5 cts., oz. 20 cts., $\frac{1}{4} \mathrm{lb}$. 60 cts., lb. $\$ 2$.

\section{BROCCOLI}

One ounce will produce 3,000 plants

Broccoli is almost identical with cauliflower, with the same general appearance and flavor, although not so refined. Start the plants in hotbeds during February, or outside in May, and when 5 inches high transplant in rows $2 \frac{1}{2}$ feet apart and 18 inches in the row. Cultivate same as for cabbage.

Early Large White. This is the best variety. It is similar to cauliflower in appearance but cannot compare with it in quality; of taller growth and the heads are not quite so compact. It is valuable for growing in cool climates and does not require so much attention as cauliflower. Pkt. 10 cts., oz. 50 cts., 1lㅣ 1 b. $\$ 1.50$.
One ounce will sow 100 feet of drill. Four pounds will sow an acre

The seed may be sown in drills 1 foot apart as early in the spring as the ground can be worked. When the plants are 3 to 4 inches high they should be thinned out so that they stand 5 inches apart. When grown in the home-garden Chicory should be blanched similar to celery. It is grown differently by market-gardeners who sow the seed in August for use the following spring when the leaves are cut off and bunched in the green state.

Witloof. The leaves are generally blanched, similar to celery, and in this way make an excellent salad. Pkt. 5 cts., oz. 25 cts., $\frac{1}{4} \mathrm{lb} .75$ cts., 1 b. $\$ 2.50$.

\section{CHIVES}

Hardy perennial plants which with little protection may remain outdoors during the winter. They appear very early in spring when the small, fine, areen leaves are cut and used for flavoring salads and also in soup. Has an onion-like flavor. Should be planted in clumps. Pkt. $10 \mathrm{cts}$.

\section{BUSH BEAN BOUNTIFUL}

For an early, flat, greenpodded Bush Bean of the highest quality, try Bountiful.

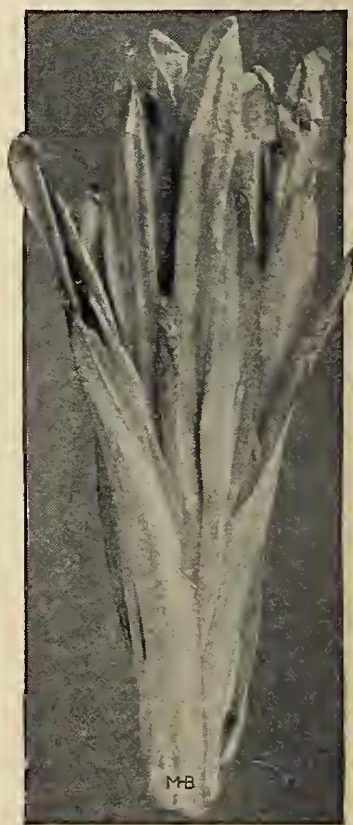

Chicorv, Witloof 
One ounce to 100 feet of row

A light, loamy soil that has been well manured the previous year is preferred for growing Carrots, although good crops may also be obtained from ordinary garden soil. For early use seed may be sown in hotbeds from January until March, and in the open ground as soon as the weather becomes warm and settled, usually in April. Sow seed $\frac{1}{2}$ inch deep in rows 15 inches apart, and later thin to 5 inches in the row. Keep soil between the rows well hoed and free from weeds. From July 1 to 15 sow for winter crops.

Chantenay, An ideal, mediumCarly, stump-rooted Carrot; smooth and uniform in shape, averaging 5 inches in length, with thick, heavy shoulders, rather large tops and deep orange color. It is a good variety whether for early or late sowing, of excellent quality and highly recommended for either the market or private gardener. Pkt. 5

cts., oz. 15 cts., $\frac{1}{4}$ lb. 40 cts., lb. $\$ 1.25$.
Parisian Forcing. Extremely early; of small size but very sweet;

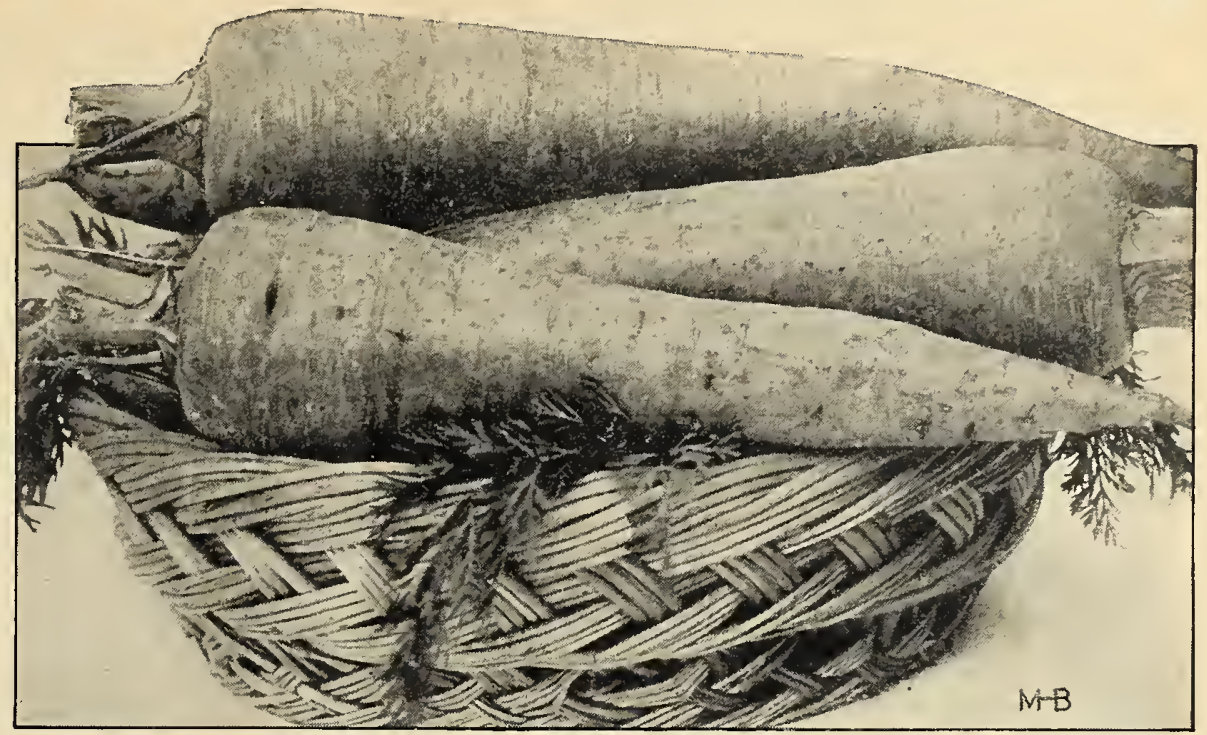
tender and beautiful orange-red color. Pkt. 5 cts., oz. 20 cts., $\frac{1}{4} \mathrm{lb}$. 60 cts., lb. $\$ 2$.

Guerande, or Oxheart. A short, thick Carrot, not exceeding 4 inches in length and about the same in width, which does quite well on hard, heavy soils where the longer varieties are useless. Pkt. 5 cts., oz. 15 ets., $\frac{1}{4}$ lb. 40 ets., lb. $\$ 1.25$.

Half-Long Nantes. (Stump-rooted.) The roots of this favorand tender, of medium size and bright orange color. It has small tops and is largely used for sowing early in the frames and the one we recommend for the home-garden. Pkt. 5 cts., oz. 15 cts., $\frac{1}{4} \mathrm{lb}$.

Improved Danvers Half-Long. An improved type of the Long, and like that variety an immense cropper and mainly grown for the fall. The roots are smooth, bright orange, of handsome appearance and the finest quality. Pkt. 5 cts., oz. 15 cts., $\frac{1}{4} \mathrm{lb} .40$ cts., lb. $\$ 1.25$.

Intermediate (St. Valery). A very handsome Carrot maturing somewhat earlier than Long Orange Improved, and of much better quality. The long, smooth roots are bright red in color, and average about 10 inches in length and from 2 to 3 inches in diameter at the top, gradually tapering to a point. Pkt. 5 ets., oz. 15 cts., $\frac{1}{4}$ lb. 40 ets., lb. $\$ 1.25$.

Danvers Half-Long. (Stump-rooted.) Owing to its enormous yield this variety is the best and most profitable for main crop, and especially desirable for feeding cattle. It is somewhat longer, thicker and a better keeper than the Chantenay, and can be depended upon to give entire satisfaction. Pkt. 5 ets., oz. 15 cts., $\frac{1}{4}$ lb. 40 cts., lb. $\$ 1.25$.

Long Orange Improved. A favorite market variety which is late in maturing and very productive. At the top the roots are about 3 inches in diameter and often measure a foot in length, gradually tapering to a point. They are deep orange in color, good keepers, and have sweet, tender flesh. A deep, mellow soil is best suited for their culture. Pkt. 5 cts., oz. 15 cts., $\frac{1}{4}$ lb. 40 ets., lb. $\$ 1.25$.

Rubicon. One of the finest half-long, stump-rooted Carrots, quite similar to the Improved Danvers in shape and size, and of deep, rich, orange-red color. It is a good keeper and matures a little later than Chantenay. Pkt. 5 ets., oz. 15 ets., ${ }_{4}^{1}$ lb. 40 cts., lb. $\$ 1.25$.

\section{GARDOON}

One ounce for 300 plants

An esteemed celery-like vegetable, the stalks of which are blanched and used for flavoring soups or stews. Sow during April or May in drills 12 inches apart, later thinning to 6 inclies in the row. Leave roots in ground until following spring, then transplant into trenches $2 \frac{1}{2}$ feet apart and 1 foot in the row, where they will rcmain for several years.

Large Solid. Grows almost 4 fect high, and has smooth leaves. Pkt. 5 ets., oz. 25 ets., $\frac{1}{4}$ lb. 75 ets., lb. $\$ 2.50$.

\section{COLLARDS}

One ounce for 3,000 plants

A variety of cabbage forming only a mass of leaves instead of a solid head, but which is estecmed most highly and extensively gromn in the South. Sow seed about the same as cabbage and later transplant 1 foot apart in rows $2 \frac{1}{2}$ feet apart. Sowings are made in the South from January to May and again in early fall.

True Georgia (Southern Creole). Vigorous and productive, growing from 2 to 3 feet higl. Pkt. 5 cts., oz. 20 cts., 21 lb. 50 cts., lb. $\$ 1.50$.

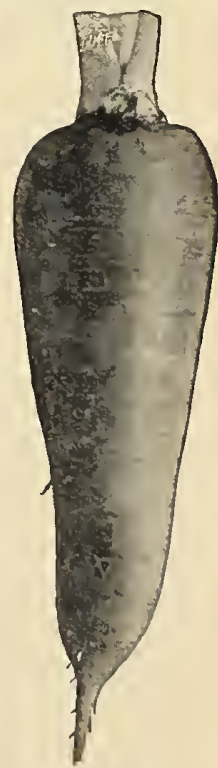

Carrot, Half-Long Nantes 


\section{CABBAGE}

One ounce will produce 3,000 plants

Almost any soil whether a light sandy loam or heavy clay, if properly prepared, will be suitable for growing Cabbage, but a rich loam with a gravelly subsoil is undoubtedly the best. Plants of the earlier varieties should be started in February and from then until June for a succession. To obtain strong, stocky plants the seedlings should be transplanted at least once before the final planting, when they are set from 1 to 2 feet apart in rows 2 to 3 feet apart, according to the variety. Insects are quite troublesome to plants grown in the open ground. Therefore, after sowing, sprinkle a small quantity of tobacco dust over the seed and also keep the young plants well covered until ready for planting. - Thorough cultivation is necessary for best results.

Brunjes' Long Island Flat Dutch. A selected strain, early or late planting and maturing about two weeks after Early Spring. The heads are medium in size but very heavy and solid, and owing to its sure heading and good keeping qualities it is a favorite, and largely planted by Long Island market-gardeners. Pkt. 10 cts., oz. $\$ 1.25$, $\frac{1}{4} \mathrm{lb}$. $\$ 4$, lb. $\$ 15$.

Allhead Early. The heads are large, round, flat, very solid and uniform in size. It is a good keeper of fine quality, and almost certain to head under any favorable conditions. Pkt. 5 cts., oz. 35 cts., $1 / 4$ lb. $\$ 1.15$, lb. $\$ 4$.

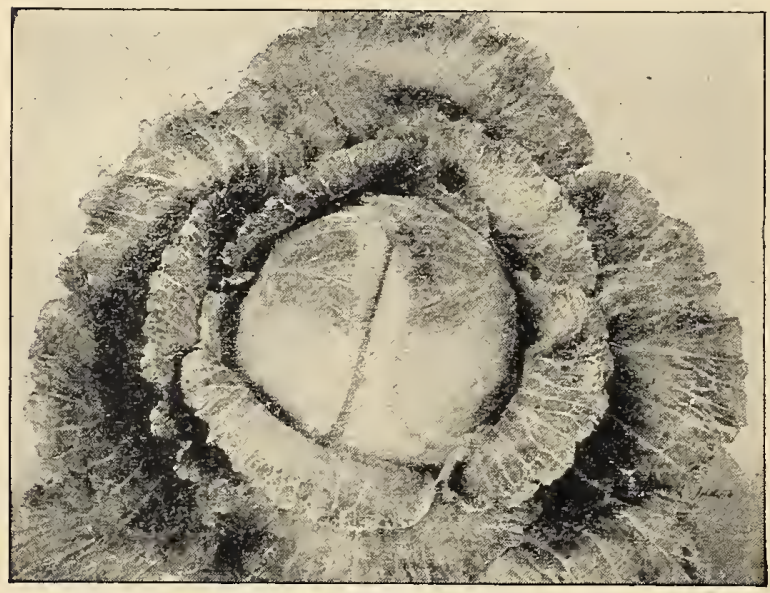

Cabbage, Succession

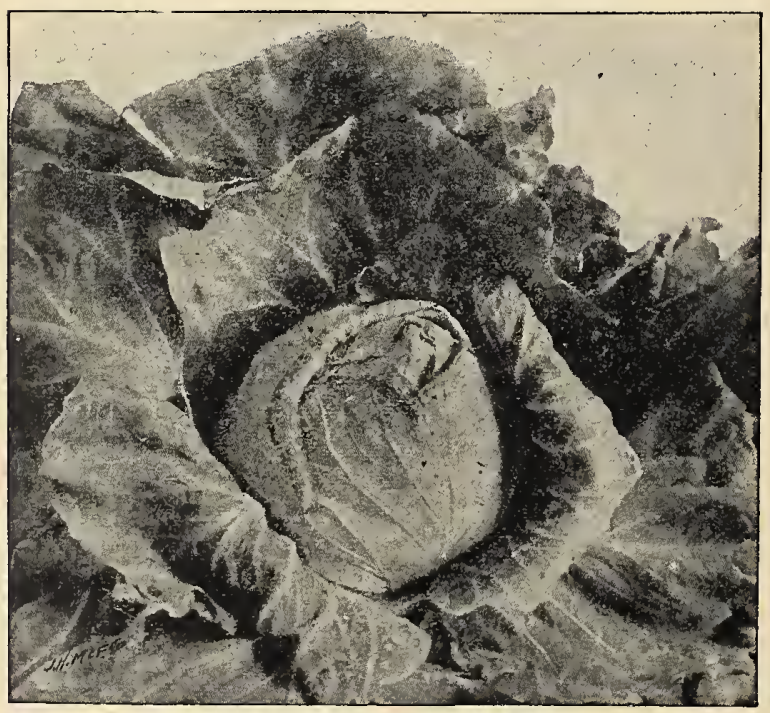

Cabbage, Charleston Wakefield

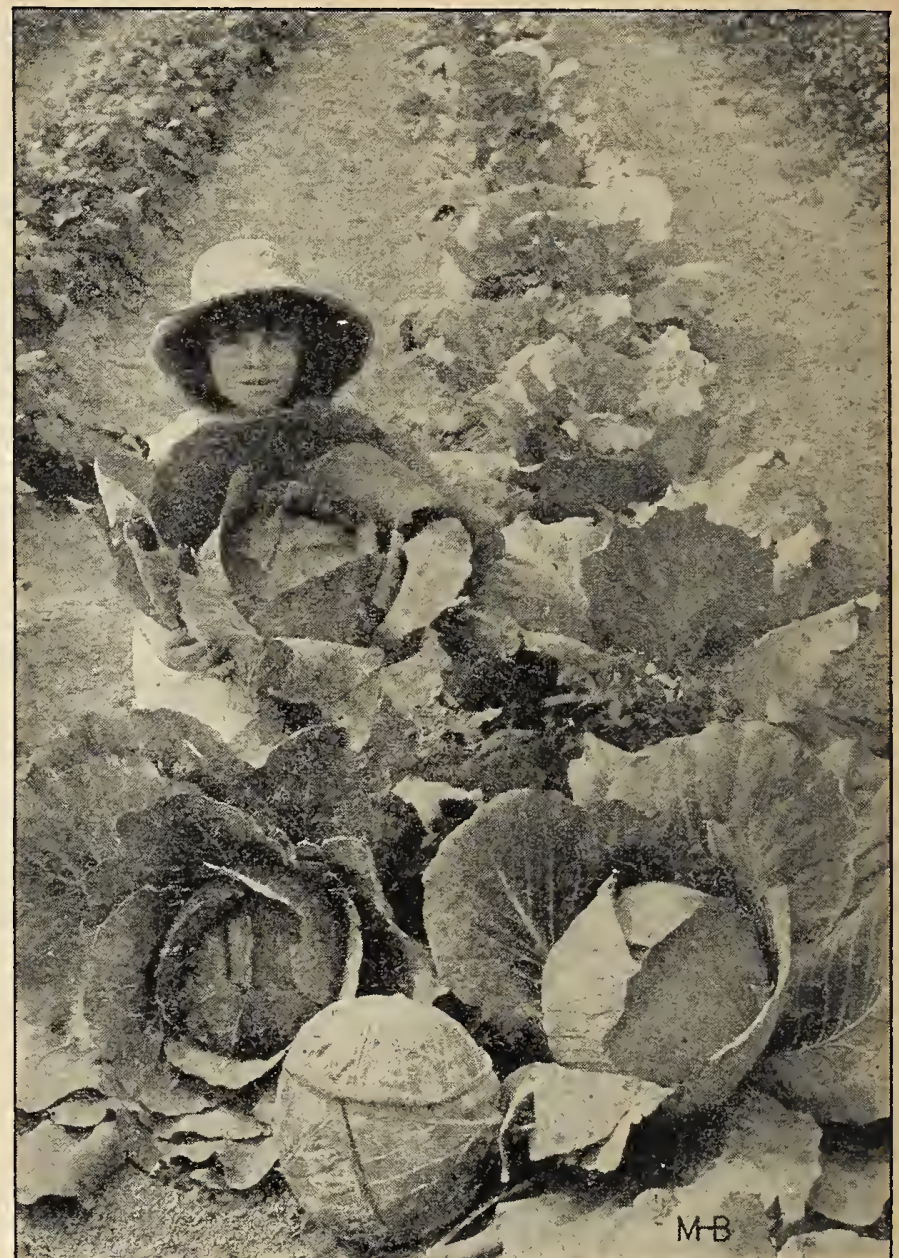

Cabbage, Brunjes' Long Island Flat Dutch

All Seasons. One of the best second-early sorts, but will also give equal satisfaction for late or intermediate planting. It withstands hot, dry weather remarkably well, forming large, solid heads, which in sweetness and tenderness may be classed with the best. Pkt. 5 cts., oz. $35 \mathrm{cts.,} 1 / 4 \mathrm{lb}$. $\$ 1.15$, lb. $\$ 4$.

Charleston Wakefield. Although a few days later than the Early Corsey Wakefield, it is larger, less pointed and equally good in quality. Invaluable for gardens where close
ing is usually necessary. Pkt. 5 cts., oz. $35 \mathrm{cts}, 1 / 4 \mathrm{lb}$. $\$ 1.15, \mathrm{lb} . \$ 4$.

Danish Ballhead, or Hollander. An excellent Cabbage for winter use, having round medium-sized heads, as solid as a rock, which remain in splendid condition until spring. Very hardy, of compact growth and withstands the cold better than any other variety. Superior for shipping. Pkt. 5 cts., oz. 50 cts., $1 / 1$ lb. $\$ 1.60$, lb. $\$ 6$.

Early Jersey Wakefield. This is the earliest Cabbage in our list and while not so large as later sorts, it is nevertheless one of the very best for early planting. The heads have few thick, outer leaves, are conicalshaped, very firm and solid and equal to any in quality. Pkt. $5 \mathrm{cts.}$. oz. 35 cts., $1 / 4$ lb. $\$ 1.15$, lb. $\$ 4$.

Surehead. A good-keeping and highly recommended Cabbage of the Flat Dutch type. The large, solid heads of excellent quality weigh from 10 to 15 pounds, are somewhat flattened at the top, and have many outer leaves. It is largely grown as a winter Cabbage for shipping, and is one of the surest-heading varieties in our list. Pkt. 5 cts., oz. $35 \mathrm{cts}$., $1 / 4 \mathrm{lb}$. $\$ 1.15,1 \mathrm{~b} . \$ 4$.

Brunjes' Early Spring. The earliest, flat-headed variety, which Jersey Wakefield, but matures ready for use about one week later than Cabbage to the acre. The heads, of medium to large size, form close to the ground, and have few very smooth dark green, outside leaves. Our strain of this variety is exceptionally fine. Plkt. $10 \mathrm{cts.}$, oz. $85 \mathrm{cts}$., $\frac{1}{4} \mathrm{lb}$. $\$ 3$, lb. $\$ 11$. 


\section{GABBAGE, continued}

Copenhagen Market. We consider this the best early about the same time as Charleston Wakefield, and has proved a most valuable variety with our Long Island gardeners. It grows compactly, allowing close planting; has large, round, solid heads of the finest quality, of ten weighing 10 to 12 pounds. Pkt. 5 cts., oz. 60 cts., 1/4lb. $\$ 2.25$, lb. $\$ 8$.

Glory of Enkhuizen. A well-recommended medium-early Cabbage for the home-garden. The plants are pale green in color and form large, round, very attractive, ball-shaped heads; thin ribbed but hard and solid. Pkt. 5 ets., oz. 40 ets., $1 / 4$ lb. $\$ 1.40$, lb. $\$ 5$.

Improved Early Summer. Early and sure-heading variety. Heads light green in color; firm, of good quality and seldom burst. Pkt. 5 cts., oz. 35 cts., $1 / 4$ lb. $\$ 1.15$, lb. $\$ 4$.

Premium Flat Dutch. An esteemed late Cabbage that is well suited for winter storing. Heads are hard, perfect in shape, and attain large size. Pkt. 5 cts., oz. 35 cts., $1 / 4$ lb. $\$ 1.15$, lb. $\$ 4$.

Succession. In every respect a model variety. It may be uns planted at all seasons but will give best results when sor. A sure header, of medium size, and finest quality. Pkt. 5 cts., oz. 35 cts., $\frac{1}{4}$ lb. $\$ 1.15$, lb. $\$ 4$.

\section{SAVOY CABBAGE}

Brunjes' Long Island Savoy. The finest of all Savoy Cabits round, deep, uniform heads, which are very large, beautifully curled and unsurpassed in quality. Like our Long Island Flat Dutch it is a sure header, excellent keeper and the very best for the market or home-garden. Pkt. 10 cts., oz. $\$ 1.25, \frac{1}{4}$ lb. $\$ 4$, lb. $\$ 15$.

Early Dwarf Ulm Savoy. An early variety with solid heads of medium size; very sweet and tender. Pkt. 5 ets., oz. 35 cts., 1/4lb. $\$ 1.15$, lb. $\$ 4$.

American Drumhead Savoy. One of the best Savoy Cabbages for general use, with fine-curled, dark green leaves and large, firm heads of good quality. Pkt. 5 cts., oz. 35 cts., $1 / 4 \mathrm{lb} . \$ 1.15$, lb. $\$ 4$.

Perfection Drumhead Savoy. Splendid for late planting. The heads a re large, solid and keep well through winter. Its fine appearance always commands the highest price in market. Pkt. 5 cts., oz. 35 cts., $1 / 4$ lb. $\$ 1.15$, lb. $\$ 4$.

\section{RED}

\section{CABBAGE}

M a m m ot $h$ Rock Red. A

fine strain which may be depended upon to form solid heads cqual to any for size and deep red color. Pkt. 5 ets., oz. 40 cts., $1 / 4 \mathrm{lb}$ $\$ 1.40$, Ib. $\$ 5$.

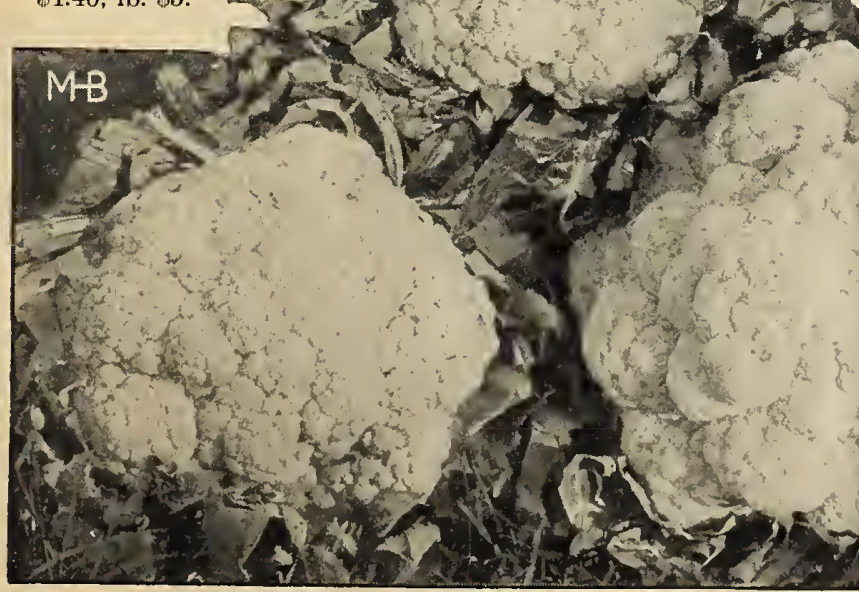

Cauliflower, Early Snowball

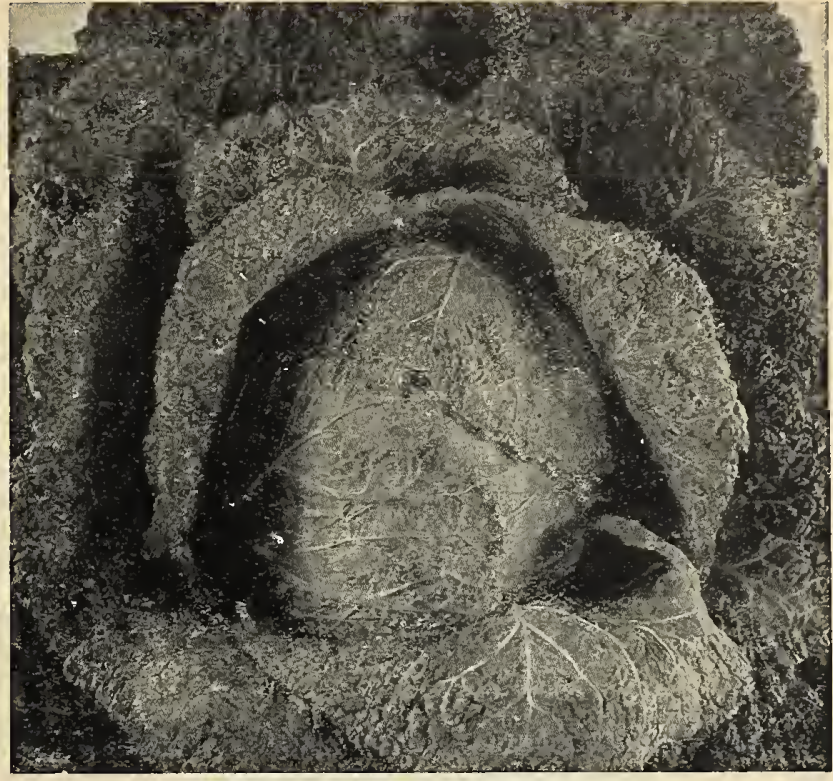

Cabbage, American Drumhead Savoy

\section{RED GABBAGE, continued}

Large Red Drumhead. A very good variety having round, dark red heads, solid and excellent for pickling. Pkt. 5 cts., oz. 40 cts., $1 / 4$ lb. $\$ 1.40, \mathrm{lb} . \$ 5$.

CABBAGE PLANTS. See päge 28.

\section{Pe-Tsai, Chinese or Celery Cabbage}

This Chinese vegetable is becoming quite popular in the American gardens. The plants are of upright growth, very much like Cos lettuce in appearance, and the heads when fully matured of ten weigh 3 to 4 pounds each. The inner leaves blanch ereamy white and may be eaten raw as a salad or cooked like asparagus. The seed should be sown the latter part of July or early in August in drills and about September transplanted in rows 2 feet apart and 15 inches apart in the row. Try it. We are sure you will like it. Pkt. $10 \mathrm{cts.,}$ oz. $50 \mathrm{cts.}$ $\frac{1}{6} l \mathrm{~b} . \$ 1.50$.

\section{Cauliflower}

One ounce for 2,000 plants

There is little difference regarding the cultural directions between the cabbage and Cauliflower, only that the latter requires richer soil and more careful attention. When the heads begin to form it is necessary to tie the leaves over the head to prevent bleaching by the sun

\section{.}

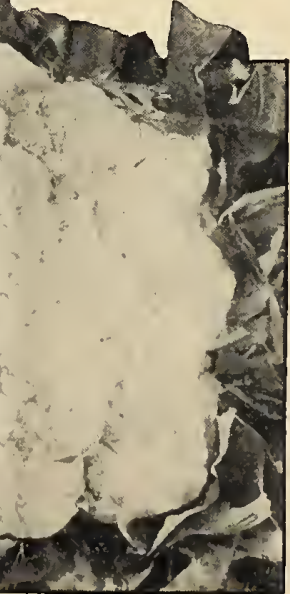

9

\section{Brunjes' Erfurt Dwarf Earliest.}

In this variety we offer a strain of Cauliflower of the highest quality and one that is certain to withstand the test of the most critical grower. It is not only superior for foreing, but succeeds just as well in the open ground, and may be depended upon to form large, handsome, pure white heads of delicious flavor. Pkt. 35 ets., $\frac{8}{4} \mathrm{oz} . \$ 1.50$, oz. $\$ 5$.

Early Snowball. A sure header, earlirr than the Extra-early Dwarf Erfurt; plants compact in growth with few small outer leaves, which allows close planting. Splendid for the private garden where space is often limited. Pkt. 25 ets., oz. $\$ 3.50$.

Extra-Early Dwarf Erfurt. An early, wellknown favorite, especially reconmended to all desiring a Cauliflower of medium size. Pkt, 25 cts., oz. $\$ 3.50$.

CA ULILLOWLR PLANTS. See page $2 S$. 


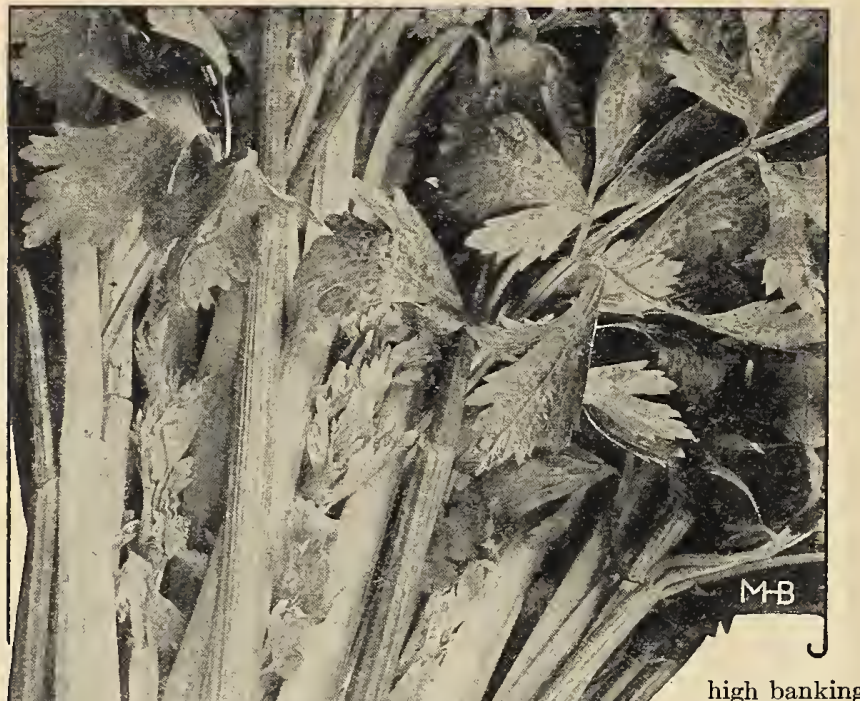

\section{CELER Y}

During April or May sow seed $\frac{1}{4}$ inch deep in drills, either in the open ground or coldframe, keeping the soil well moist until seed germinates. When the plants are about 2 inches high, thinning out is necessary, and then after attaining a height of 5 inches they are ready to be transplanted, usually in July, to final beds of very rich soil. Set plants every 6 inches in rows 3 feet apart. Keep space between rows cultivated and free from weeds. For early use begin blanching in September by drawing up the soil to within a few inches of the top and firm well around the plants. Select every other row for early use, thus giving the remaining Celery more room for late blanching.

Golden Self-blanching. This early, self-blanching Celery with little banking the handsome, solid stalks as well as the heart become a rich golden yellow. The plants are dwarf and stocky, very attractive when bunched, and command a ready sale and a high price in the market. Very largely grown, and the best yellow table Celery, either for the home or market-gardener. We offer true French-grown stock, and there is none better. Pkt. 10 cts., oz. 75 cts., $\frac{1}{4} 1 \mathrm{~b} . \$ 2.50, \mathrm{lb}$. $\$ 8$.

White Plume. A variety especially adapted to cultivation by naturally white, and do not require blanching by the old process of high banking. By simply tying up the stalks and drawing up the soil with the hoe, the work of blanching is complete. It is tender, crisp and of good flavor. Pkt. 5 cts., oz. 40 cts., $\frac{1}{4}$ lb. $\$ 1.25$, lb. $\$ 4$.

Columbia. Words of highest praise have been received from growers of this new Celery. Stalks thick and stocky, well shaped and when blanched resembles the Golden Selfblanching. Pkt. 5 cts., oz. 40 ets., $\frac{1}{4}$ lb. $\$ 1.25$, lb. $\$ 4$.

French's Success. A new green Celery of compact growth, possessing the finest flavor and recommended for its keeping qualities. Pkt. 5 cts., oz. 40 cts., $\frac{1}{4}$ lb. $\$ 1.25,1 \mathrm{~b}$. $\$ 4$.

Giant Pascal. A most desirable early winter variety having broad, stringless stalks which blanch quickly to a beautiful creamy white. Pkt. 5 cts., oz. 20 cts., $\frac{1}{4}$ lb. 60 cts., lb. $\$ 2$.

Perfection Heartwell. An excellent Celery of rather tall growth, with a golden yellow erfection Heartwell. heart, and round, thick stalks of the finest flavor. It is a good keeper and largely grown by our market-gardeners. Pkt. 5 cts., oz. 20 cts., $\frac{1}{1}$ lb. 60 cts., lb. $\$ 2$.

Schumacher. A reliable variety with com-

paratively large stalks; solid but crisp and

tender. Pkt. 5 cts., oz. 20 cts., $\frac{1}{4}$ lb. 60 cts., lb. $\$ 2$.

Soup, or Cutting. This variety is adapted to sowing thick in rows and cutting when 5 or 6 inches high, to use for soup-flavoring. It can be cut repeatedly and will furnish a succession throughout the season. Pkt. 5 cts., oz. 20 cts., $\frac{1}{4} \mathrm{lb} .60 \mathrm{cts}$. lb. $\$ 2$.

Winter Queen. As a winter-keeping Celery there are

few that can compare with this superior variety. It is noted not only for its good keeping qualities, but also for the thick, heavy stalks, almost all heart, which blanch

to a creamy white and possess that rich nutty flavor so much desired in Celery. Pkt. 5c., oz. 20c., 妾lb. 60c., lb. $\$ 2$.

Boston Market. Distinct from all other varieties. Plants grow very bushy with innumerable side shoots, which form many very bushy with innumerable side shoots, which form many
small instead of one large head. Withstands continuous cutting and, like the Soup, or Cutting, is excellent for soup greens. Pkt. 5 cts., oz. 20 cts., $\frac{1}{4}$ lb. 60 cts., lb. $\$ 2$.

Celery, Golden Self-blanching

Dwarf Golden Heart. Fine for market or garden, excellent keeper, very solid, and the heart is a golden yellow when blanched. Pkt. 5 cts., oz. 20 cts., $\frac{1}{4}$ lb. 60 cts., lb. $\$ 2$.

CELERY SEED FOR FLAVORING. Oz. 5 cts., $\frac{1}{4} \mathrm{lb} .15 \mathrm{cts} ., \mathrm{lb} .50 \mathrm{cts}$.

GELERY PLA NTS. See page 28

\section{CELERIAC (Turnip-rooted Gelery)}

This vegetable is grown principally for its bulb-like roots, the flavor of which is highly esteemed in soups and stews. For early use, first sowings are made in frames the beginning of March, but outdoor sowings during April and May are recommended if roots are desired for winter. Like Celery, sow seed $\frac{1}{4}$ inch deep in drills 10 inches apart, and when plants are stocky transplant to beds of rich, deep soil, 6 inches apart in rows $1_{4}^{1}$ feet apart. Cultivate thoroughly and remove but little of the greens until the bulb is of good size.

Large Smooth Prague. The finest of all Celeriac. Roots measure from 2 to 4 inches in diameter; round, smooth and comparatively few side roots. Pkt. 5 cts., oz. 40 cts., $\frac{1}{4}$ lb. $\$ 1.25$, lb. $\$ 4$.

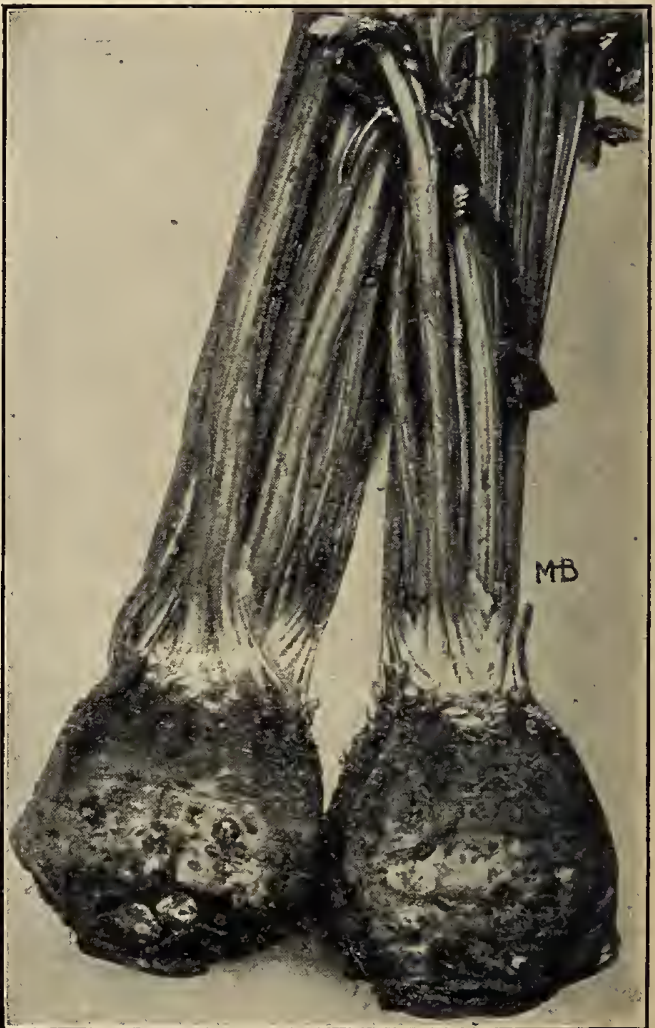

Celeriac, Large Smooth Prague 


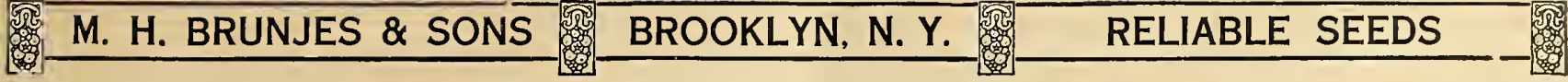

\section{CUCUMBER}

One ounce will plant 50 hills

After danger from frost is over, usually early in May, sow seed $\frac{1}{2}$ inch deep in hills not less than 4 feet apart each way, dropping about twelve seeds in each hill. Later, when plants are well started, thin out, leaving only five or six of the strongest to every hill. A rich soil that has been well manured is most profitable for Cucumbers. Sow seed for pickles during June and July.

Early Fortune. Whether for the farm you will find Early Fortune just the $\mathrm{Cu}$ cumber you want. The fruit is long and slightly tapering, averaging 9 inches in length, has firm white flesh and few seeds. It is wonderfully productive and retains its dark green color longer than other white spine varieties. Pkt. 5 cts., oz. 20 cts., $\frac{1}{4}$ lb. 50 ets., lb. $\$ 1.50$.

Cool and Crisp. An excellent Cucumber for slicing, but when small is equally good for pickling. Flesh pure white, tender and crisp. Pkt. 5 cts., oz. 15 ets., $\frac{1}{4} 1 \mathrm{~b} .40$ ets., lb. $\$ 1.25$.

Davis Perfect. A type of white spine with favor either for forcing or open to meet culture. It is a handsome, extra-long Cucumber, delightfully flavored and retains its deep glossy green color until near maturity. Pkt. 5 cts., $0 z .15$ cts., $\frac{1}{4} 1$ b. 40 cts., lb. $\$ 1.25$.

Early White Spine. For general crop this variety may well be Early White Spine. relied upon both for quantity and quality. Medium size, beautiful color and keeps in good condition long after picking. Pkt. 5 cts., oz. 15 cts., $\frac{1}{4} l$ b. 40 cts., lb. $\$ 1.25$.

Extra-long, or Evergreen White Spine. This is one White Spine Cucumbers either for the market or private garden. Matures somewhat later than the Early White Spine, but exceeds it in length; equally productive and darker in color. Pkt. 5 ets., oz. 15 cts., $\frac{1}{4}$ lb. 40 cts., lb. $\$ 1.25$.

Green Prolific, or Boston Pickling. Fruits are small, bright green, very smooth and yield an unusually large number of pickles to the acre. Pkt. 5 cts., oz. 15 cts., $\frac{1}{4}$ lb. 40 cts., lb. $\$ 1.25$.

Improved Long Green. Grows from 10 to 12 inches long, thick, dark green and one of the best flavored. At maturity the fruits become rich yellow and are then esteemed for making mustard Cucumbers. Pkt. 5 ets., oz. 15 ets., $\frac{x}{4}$ lb. 40 ets., lb. $\$ 1.25$.

Klondike. There are many fine Cucumbers and this is one of them. When ready for use the fruit is about 7 inches long and 2 inches thick, very dark green in color, of excellent quality and fine for slieing. Pkt. 5 cts., oz. 15 ets., 1 lb. 40 cts., lb. $\$ 1.25$.

Japanese Climbing. A distinct variety which may be trained to a pole or trellis and bearing throughout the summer extra-long, smooth, well-flavored Cucumbers. Pkt. 5 cts., oz. 20 cts., $\frac{1}{4}$ lb. 50 cts., lb. $\$ 1.50$.

West India Gherkin. Pkt. 5 cts., oz. 20 cts., ${ }_{4}^{1}$ lb. 60 cts., lb. $\$ 2$.

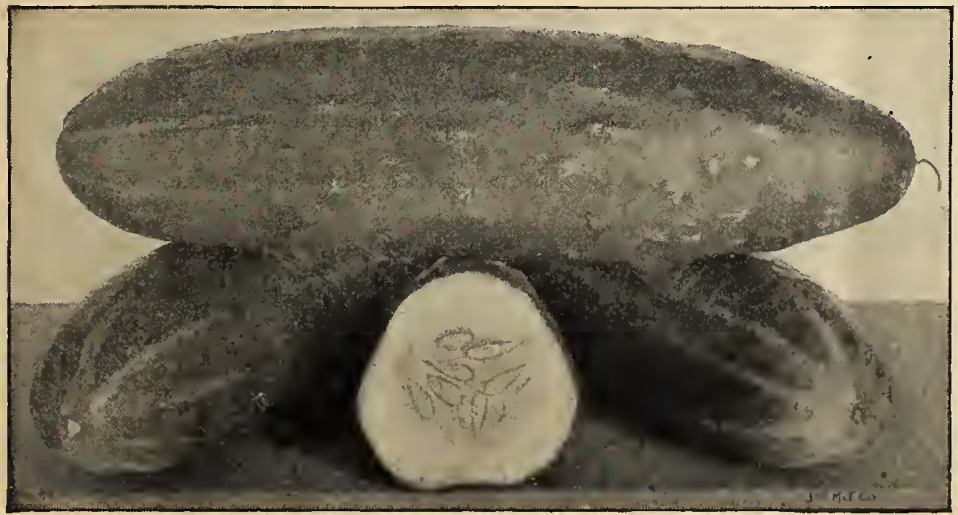

Cucumber, Extra-long, or Evergreen White Spine

\section{GORN SALAD One ounce will sow}

This small green salad, so often called Field Salad, may be had throughout the greater part of the winter, providing it is given a slight covering of coarse litter or straw. Seed should be sown quite thickly in August and September in drills 10 inches apart. In sowing, do not cover the seed more than one-fourtl inch, but see that the soil is pressed firmly over the seed to hasten germination. A sowing may also be made in early spring.

Large-seeded. Pkt. 5 cts., Oz. 15 cts., 1/4lb. 40 cts., lb. $\$ 1.25$.

\section{CRESS One ounce will sow}

The seed should be sown early in the spring on rich ground, quite thickly, in shallow drills, about 1 foot apart. For succession, sow every ten days, as it soon runs to seed. A supply may be had during the winter months by sowing the seed in shallow boxes and placing in a warm, sunny situation.

Extra Curled. The leaves, which have a peculiar taste, are used as a salad. Pkt. 5 ets., oz. 10 ets., $\frac{x}{4}$ lb. 30 cts., lb. 90 ets.

\section{WATER-CRESS}

Requires a moist situation, or, better still, a running stream where seed may be sown along the banks in spring. It can be eut the second year.

Common. Pkt. 10 cts., oz. 30 cts., $\frac{1}{4}$ lb. $\$ 1$.

True Erfurt. Superior to the above and of a milder flavor. Plit. 10 ets., oz. 40 cts., $\frac{1}{4} \mathrm{lb}$. $\$ 1.25$. 


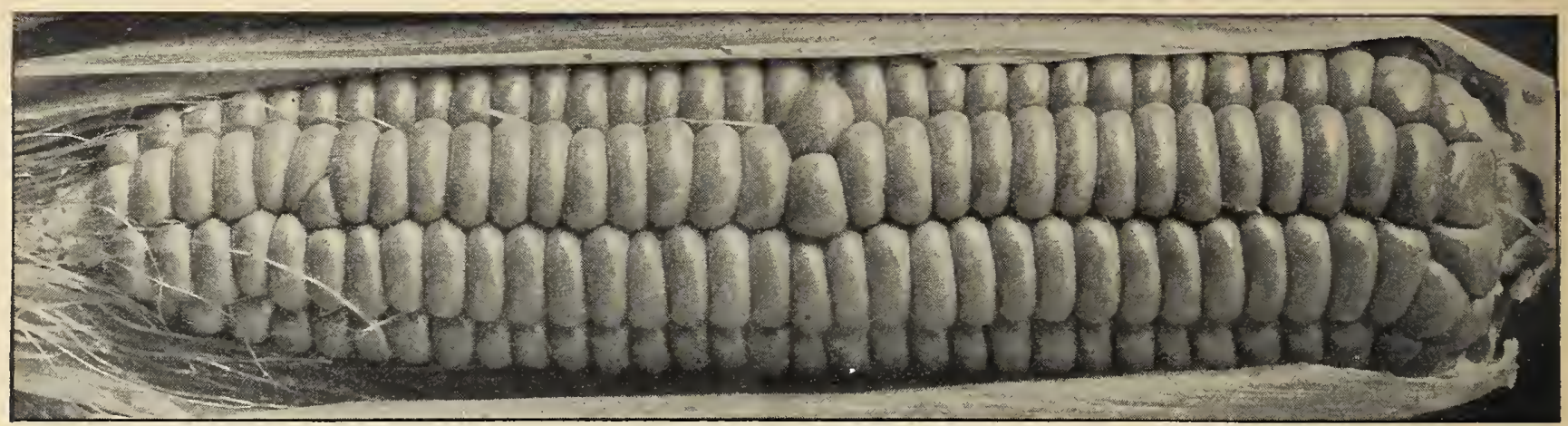

Sweet Corn, Golden Bantam

\section{CORN, Sweet or Sugar}

A deep, rich soil is best adapted to growing Corn. As it is quite sensitive to cold; planting should be withheld until the ground becomes warm and mellow, usually early in May. Plant in hills from 2 to 3 feet apart according to the variety, dropping about five kernels in each, and cover 1 inch; later thin to three plants to a hill. Cultivate thoroughly between the rows and keep the soil hoed well up to the plants. For a continuous supply during the season, plantings should be made every few weeks until the latter part of July. One pound will plant 300 hills; 12 pounds will plant an acre.

IF BY PARCEL POST, ADD POSTAGE AT ZONE RATE

\section{EARLY VARIETIES}

Early Mayflower. Gardeners who take pride in having the do well to try Early Mayflest vegetables in their locality would moth White Cory; has ears of good size, which are well filled with sweet, tender, white kernels. 1/21b. 15 cts., lb. 30 cts., 2 lbs. 55 cts., 10 lbs. $\$ 2.25$.

Golden Bantam. May be planted at least a week earlier and . will mature before most all other Sweet Corns. The stalks grow about 4 feet high, each producing two or more ears measuring from 5 to 7 inches in length. When ready for use the kernels are bright golden yellow, deliciously sweet, richly flavored, and remain tender for some time after ripening. 1/2lb. 15 cts., lb. 30 cts., 2 lbs. 55 cts., 10 lbs. $\$ 2.25$.

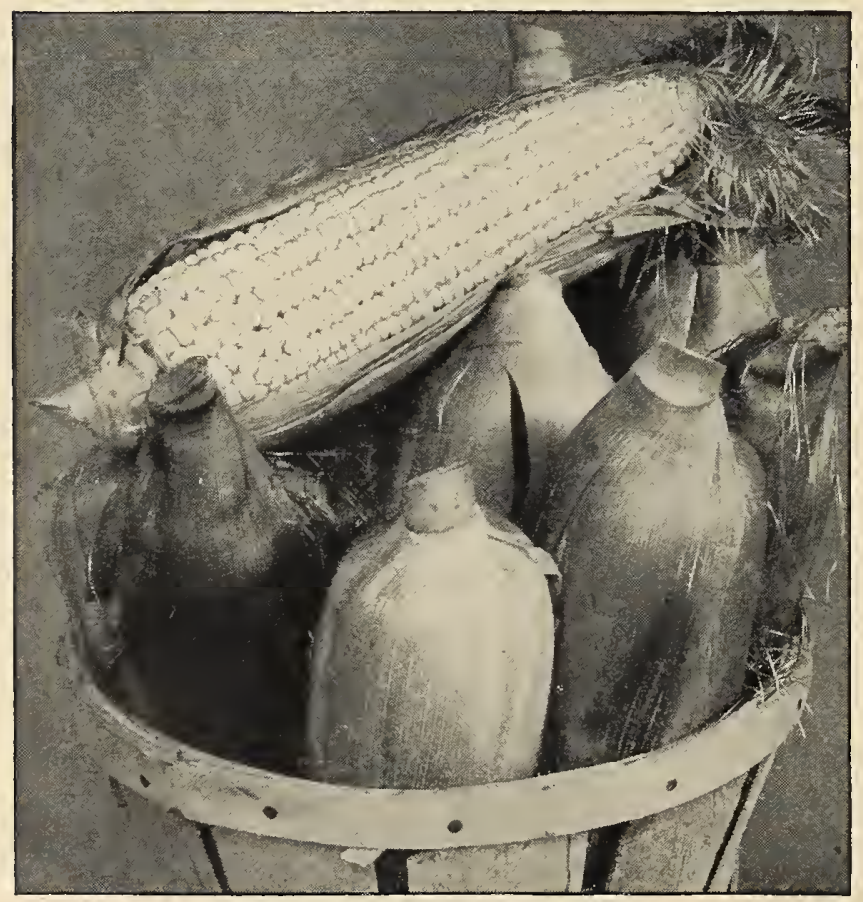

Sweet Corn, Early Evergreen
Bantam Evergreen. This new introduction is one of the finest Bantam Evergreen. and sweetest Corns in our list, and we ask all to give it a trial. The ears, 8 inches long and 12-rowed, are larger than Golden Bantam and the deep, rich, golden kernels just as sweet. $1 / 2 \mathrm{lb} .15$ cts., lb. 30 cts., 2 lbs. 55 cts., 10 lbs. $\$ 2.25$.

Kendel's Early Giant. A valuable early Sweet Corn. The ears grow to a tremendous size, measuring 8 to 10 inches long, and having 10 to 14 rows on each cob, the majority having 12 rows; kernels pure white, sweet, tender. 1/2lb. 15 cts., lb. $30 \mathrm{cts.,} 2 \mathrm{lbs} .55 \mathrm{cts}$., 10 lbs. $\$ 2.25$.

Mammoth White Cory. An extra-large Corn, considering its extreme earliness. The stalks generally grow 4 feet high, each one usually bearing 2 ears of good quality, 1/2lb. $15 \mathrm{cts} ., 1 \mathrm{lb} .30 \mathrm{cts.}$, 2 lbs. 55 cts., 10 lbs. $\$ 2.25$.

Premo. As an early variety (and there are many of them), few surpass this one for the home table. Although of rapid growth, ripening in about sixty days, the ears are extra large and of fine quality. $1 / 2$ lb. 15 cts., lb. 30 cts., 2 lbs. 55 cts., 10 lbs. $\$ 2.25$.

\section{MEDIUM-EARLY VARIETIES}

Brunjes' Long Island Beauty. This splendid Sweet many as one of the very best second-early sorts. The ears, although somewhat shorter than those of the Early Mammoth, are much thicker, ripen about a week earlier and make one of the finest and showiest Corns when ready for market. It is a Corn that all should grow, being sweet, very tender and possessing the rich sugary flavor of Stowell's Evergreen. 1/2lb. 15 cts., lb. 30 cts., 2 lbs. 55 cts., 10 lbs. $\$ 2.25$.

Early Champion. One of the best medium-early varieties. Ears are large, well formed with clear white, sweet kernels and can be highly recommended for the market or garden. $1 / 2 \mathrm{lb} .15 \mathrm{cts} ., 1 \mathrm{~b}$. 30 ets., 2 lbs. 55 cts., 10 lbs. $\$ 2.25$.

Early Evergreen. From a week to ten days earlier than Stowell's Evergreen, with somewhat shorter ears but otherwise possessing all the good qualities of that famous Corn. Good market variety. $1 / 2$ lb. 15 cts., lb. 30 cts., 2 lbs. 55 cts., 10 lbs. $\$ 2.25$.

Early Mammoth. A popular Sugar Corn of great merit; earlier than the Late Mammoth and far better adapted for the private garden. The ears, of fine quality, are long but not very thick. $1 / 2 \mathrm{lb} .15$ cts., 1 b. 30 cts., 2 lbs. 55 cts., 10 lbs. $\$ 2.25$.

Perry's Hybrid. Popular among the market-gardeners as an intermediate sort. A fine Corn for the table, with ears of good length, very sweet and maturing after the smaller-eared varieties. $\frac{1}{2} \mathrm{lb}$. 15 cts., lb. 30 cts., 2 lbs. 55 cts., 10 lbs. $\$ 2.25$.

Potter's Excelsior (Squantum). The ears of this grand Sugar Corn are large and well filled with twelve rows of decp, snowy white kernels. Its sweetness and delicious flavor afford it a place with the best garden varieties.
Well known and extensively used for canning purposes. 1/2lb. 15 cts., lb. 30 cts., 2 lbs. 55 cts., 10 lbs. $\$ 2.25$. 


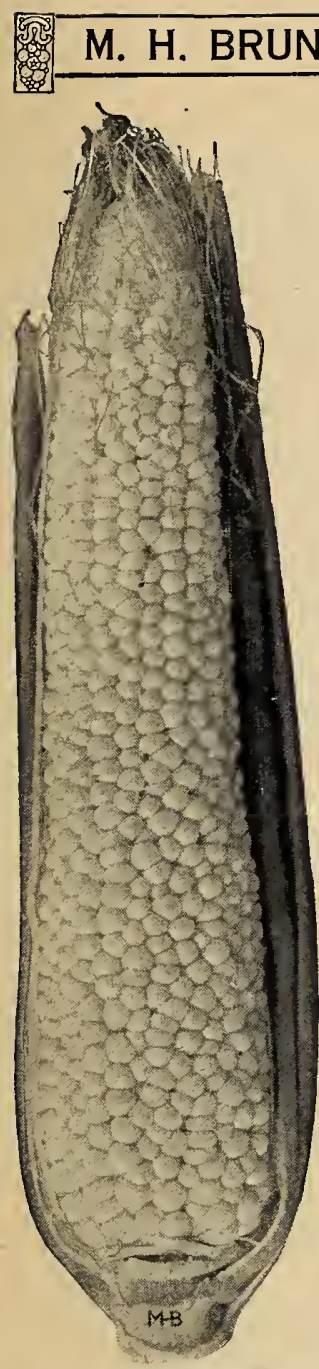

BROOKLYN, N. Y.

RELIABLE SEEDS

CORN, SWEET or SUGAR, continued

\section{LATE VARIETIES}

Country Gentleman. Quite late in ripening. The long, deep-grained are the sweetest of any variety in cultivation. $1 \frac{1}{2} \mathrm{lb} .15 \mathrm{cts}$., $1 \mathrm{~b}$. $30 \mathrm{cts}$., 2 lbs. $55 \mathrm{cts}$., 10 lbs. $\$ 2.25$.

Stowell's Evergreen. The well-known late sort, and one of the best and thick ears are well filled to most largely planted for general use. The large, than most varieties. $\frac{1}{2} \mathrm{lb} .15 \mathrm{cts}$., lb. $30 \mathrm{cts}$., 2 lbs. 55 cts:, $10 \mathrm{lbs}$. $\$ 2.25$.

White Evergreen. This may readily be called a White Stowell's Evergreen. Though similar to that variety in size, it is ready for picking a few days earlier, while its most valuable feature lies in the pure whiteness of the long, slender grains. $\frac{1}{2} l$ b. 15 cts., lb. 30 cts., 2 lbs. 55 cts., 10 lbs. $\$ 2.25$.

Mammoth Late. Mainly planted by market-gardeners. The stalks grow very high, and bear the largest ears of any Sweet Corn. $\frac{1}{2} \mathrm{lb} .15 \mathrm{cts} .$, lb. 30 cts., 2 lbs. 55 cts., 10 lbs. $\$ 2.25$.

\section{POP GORN}

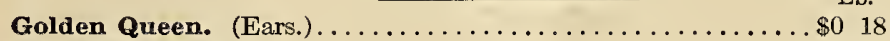

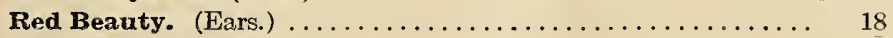

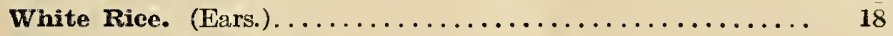

$100 \mathrm{lbs}$. $\$ 1500$

1500

Field Corn. See page 28.

\section{DANDELION}

\section{One ounce will sow 100 feet of drill}

This is one of the earliest spring vegetables. When small the leaves are very tender and esteemed for making salad. Sow the seed in spring, when the soil becomes warm, usually in April, and from then until the middle of August, in rows one foot apart and ${ }_{4}^{1}$ inch deep. It remains over winter and is ready for cutting the following spring. If the roots are not disturbed, they will grow again, affording another supply the next year.

French. Common. Pkt. 10 cts., oz. 50 cts., $\frac{1}{4}$ lb. $\$ 1.60$, lb. $\$ 6$.

\section{DILL}

One ounce will sow 200 feet of drill

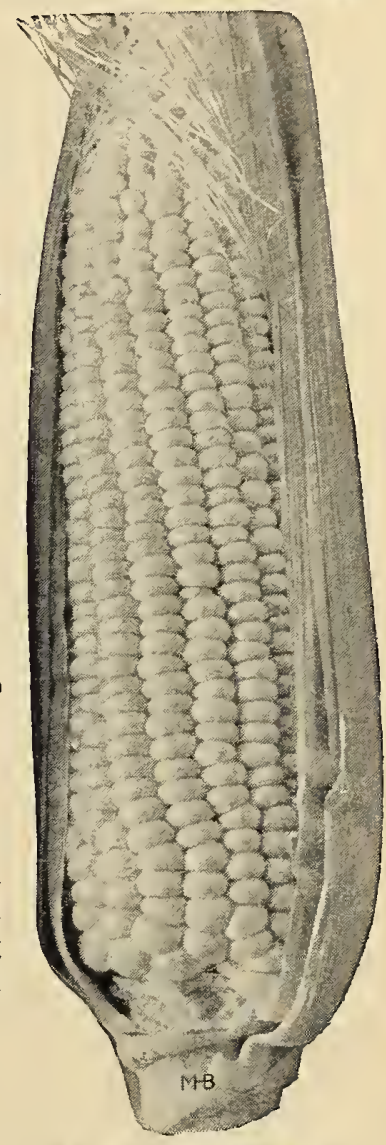

Corn, Stowell's Evergreen

From May 15 to June 15 sow seed $\frac{1}{2}$ inch deep in drills $1 \frac{1}{2}$ feet apart. Unless the plants stand very thick, it is not necessary to thin out, but keep soil cultivated and free from weeds.

Brunjes' Mammoth. Far superior to the Common variety, and grown largely by our farmers for the Pkt. 5 cts., oz. 20 cts., $\frac{1}{4} 1 \mathrm{lb} .60$ cts., lb. $\$ 2.25$.

Corn, Country Gentleman

Common. While of dwarfer growth than the preceding variety, it is best suited for the home-garden; splendid for flavoring pickles. Pkt. 5 cts., oz. 20 cts., $\frac{1}{6}$ lb. 50 cts., lb. $\$ 1.50$.

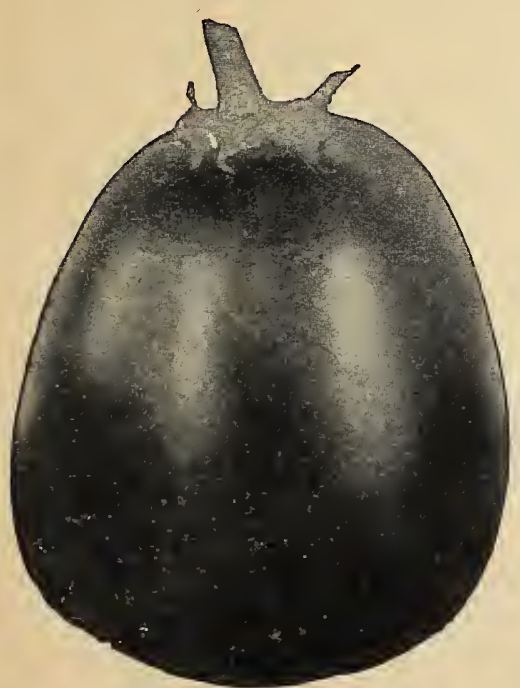

Eggplant, Black Beauty

\section{Eggoplant}

One ounce will produce 1,000 plants

As the seed of Eggplant is slow in germinating, it should be sown in a hotbed or greenhouse where it will receive the benefit of as much heat as possible. Sow seed during February and the early part of March, and as the plants are very sensitive, they should not be transplanted to the open ground until June, when all danger of cool weather is past. The plants should be transplanted at least once in the frames before the final setting out. Set plants $2 \frac{1}{2}$ feet apart each way.

New York Improved Purple. This is not only the finest Eggplant for the garden, but it is the largest and most profitable for the market as well. The plants are spineless, very productive, yielding from four to six extra-large, oval-shaped fruits of a beautiful rich purple. It is early, and of the finest quality. Pkt. 10 cts., oz. 50 cts., $\frac{1}{4}$ lb. $\$ 1.90$, lb. $\$ 7$.

Black Beauty. Although this variety is not quite so large as the well-known New York Improved Purple, it matures from a week to ten days earlier. The fruits have thick flesh and are very attractive in appearance, being of a rich, glossy, purplish black color. Plants are of strong, stocky
oz. 60 cts., $\frac{\pi}{4} \mathrm{Ib} . \$ 2, \mathrm{lb}$. $\$ 7.75$.

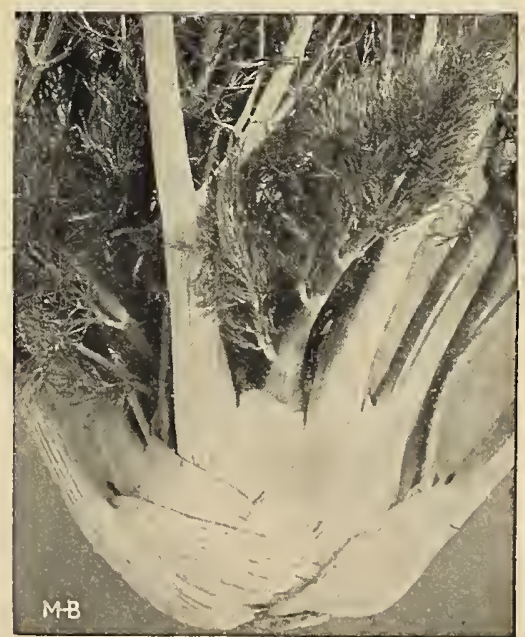

Fennel, Florence (see page 14) 


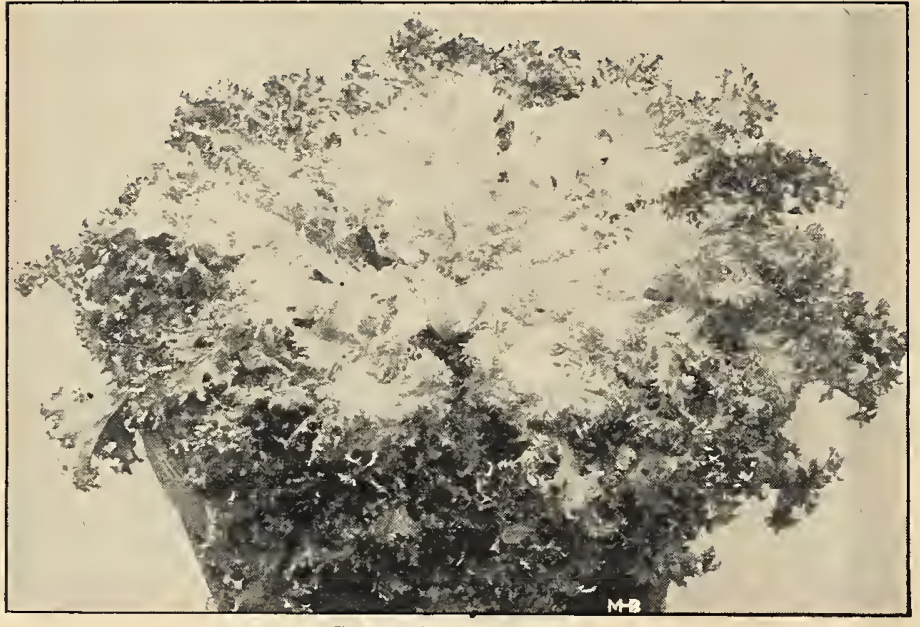

Endive, Large Green Curled

\section{Endive $\begin{gathered}\text { One ounce will sow } \\ 200 \text { set of of rill }\end{gathered}$}

Sow seed $\frac{1}{2}$ inch deep in rows 12 inches apart from May 15 until the middle of August. After the plants are well advanced they should bo transplanted in rows 15 inches apart and 12 inches apart in the row, thus securing larger heads than if only thinned out. When nearly full grown, draw the leaves together and tie at the top to blanch the heart.

Brunjes' Large Green Curled (Chicory). Leaves are quite deeply laciniated and form large, flat heads which blanch readily to a creamy white. There are several inferior varieties of this Endive being offered and a trial of our stock will prove its superiority. Pkt. 5 cts., oz. 20 cts., $\frac{1}{4}$ lb. 60 cts., lb. $\$ 2$.

White Curled. An ideal variety for the private garden. Leaves very tender, especially striking in appearance and blanch somewhat easier than the above. Pkt. 5 cts., oz. 20 cts., $\frac{1}{4}$ lb. 60 cts., lb. $\$ 2$.

Broad-leaved Batavian (Escarolle). An excellent strain with thick, broad leaves, slightly curled; bright green at first, but when blanched the heart becomes white and crisp. Pkt. 5 cts., $0 z .20$ cts., $\frac{1}{4} 1 \mathrm{~b} .60$ cts., lb. $\$ 2$.

KOHLRA BI PLANTS. See page 28

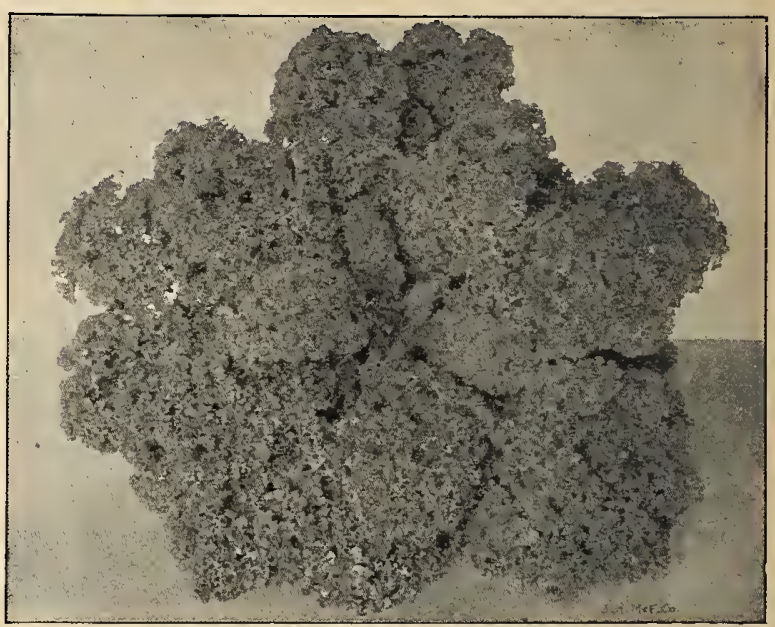

Kale, Dwarf Green Curled Scotch

\section{Kale, or Borecole}

\section{One ounce will produce 3,000 plants}

This vegetable may be had at almost all seasons of the year, but it does not reach perfection until the winter months. For summer use sowings are made in April, while for winter greens June is the best month. Sow in drills $\frac{1}{4}$ inch deep, and later reset plants 2 feet apart each way.

Dwarf Green Curled Scotch. Noted for its extreme hardiness, dwarf, compact habit and extra-fine curled leaves. Pkt. 5 cts., oz. 20 cts., $\frac{1}{4}$ lb. 60 cts., lb. $\$ 2.25$.

Tall Green Curled Scotch. Heads are formed on stalks $2 \frac{1}{2}$ feet high; color bright green and leaves exceedingly curly. Pkt. 5 ets., oz. 20 cts., $\frac{1}{4} 1 \mathrm{~b}$. 60 cts., lb. $\$ 2.25$.

Dwarf Brown. Similar in growth to the Dwarf Green Curled Scotch. The leaves are purple in color, tender and preferred by many to that variety. Pkt. 5 cts., oz. 25 cts., $1 / 4$ lb. 75 cts., lb. $\$ 2.50$.

\section{SIBERIAN KALE, ox SPROUTS}

There is little difference in taste and flavor between Kale and Sprouts. The former is ready for use during the fall and winter months, while the latter can only be used the following spring. Sow seed during August in drills 1 foot apart.

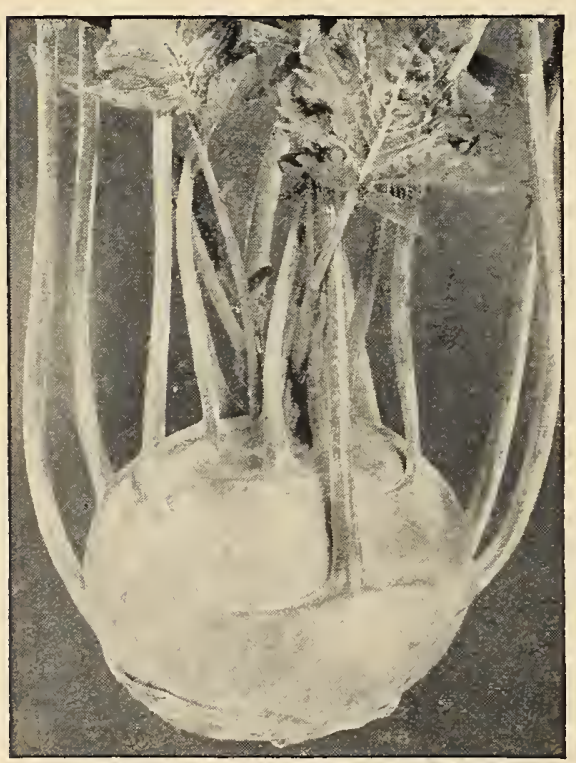

Kohlrabi, Early White Vienna

Brunjes' Long Island Early. Pkt. 5 cts., oz. 20 cts., $\frac{1}{4}$ lb. 60 cts., lb. $\$ 2$.

Brunjes' Long Island Late. Pkt. 5 cts., oz. 20 cts., $\frac{1}{4} 1 \mathrm{~b} .60$ cts., lb. $\$ 2$.

\section{Kohlrabi}

The bulb-like portion of this vegetable is of delicate flavor, especially when small, and cooked similar to white turnips. For early use sow seed outdoors during April and from then on for succession in drills 15 inches apart; later thin out to 6 inches in the row.

Early White Vienna. (Frames.) A short-leaved variety which succeeds well in frames but may also be sown in the open ground. Pkt. 5 cts., oz. 30 cts., $\frac{1}{4} \mathrm{lb} .90 \mathrm{cts}$., lb. $\$ 3$.

Early White Vienna. Excellent for sowing outside. The leaves grow somewhat larger than the Early White Vienna for frames. Pkt. 5 cts., oz. 30 cts., $\frac{11}{4} 1$ b. 90 cts., lb. $\$ 3$.

Early Purple Vienna. Leaves and bulbs are rich purple in color, but the flesh is tender and of fine quality. Pkt. 5 cts., oz. 30 cts., $\frac{1}{4} \mathrm{lb} .90$ cts., 1 b. $\$ 3$.

\section{FENNEL}

For succession sow from June 15 to July 15 in rows $1 \frac{1}{2}$ to 2 feet apart, and later thin out to 5 inches in the row. Earlier sowings frequently run to seed.

Florence, or Naples. Grows about 2 feet high, forming an oval-shaped bulb just above the ground. Has a peculiar, but very sweet, celery-like taste. Pkt. 5 cts., oz. 20 cts., $\frac{1}{4} \mathrm{lb} .60 \mathrm{cts} ., 1 \mathrm{~b} . \$ 2.25$.

\section{GARLIC}

Plant sets every 4 inches in rows 10 inches apart. After the tops turn yellow gather the buibs and store in a dry place like onions. Lb. 75 cts. 


\begin{tabular}{|c|c|c|}
\hline M. H. BRUNJES \& SONS & BROOKLYN, N.Y. & RELIABLE SEEDS \\
\hline
\end{tabular}

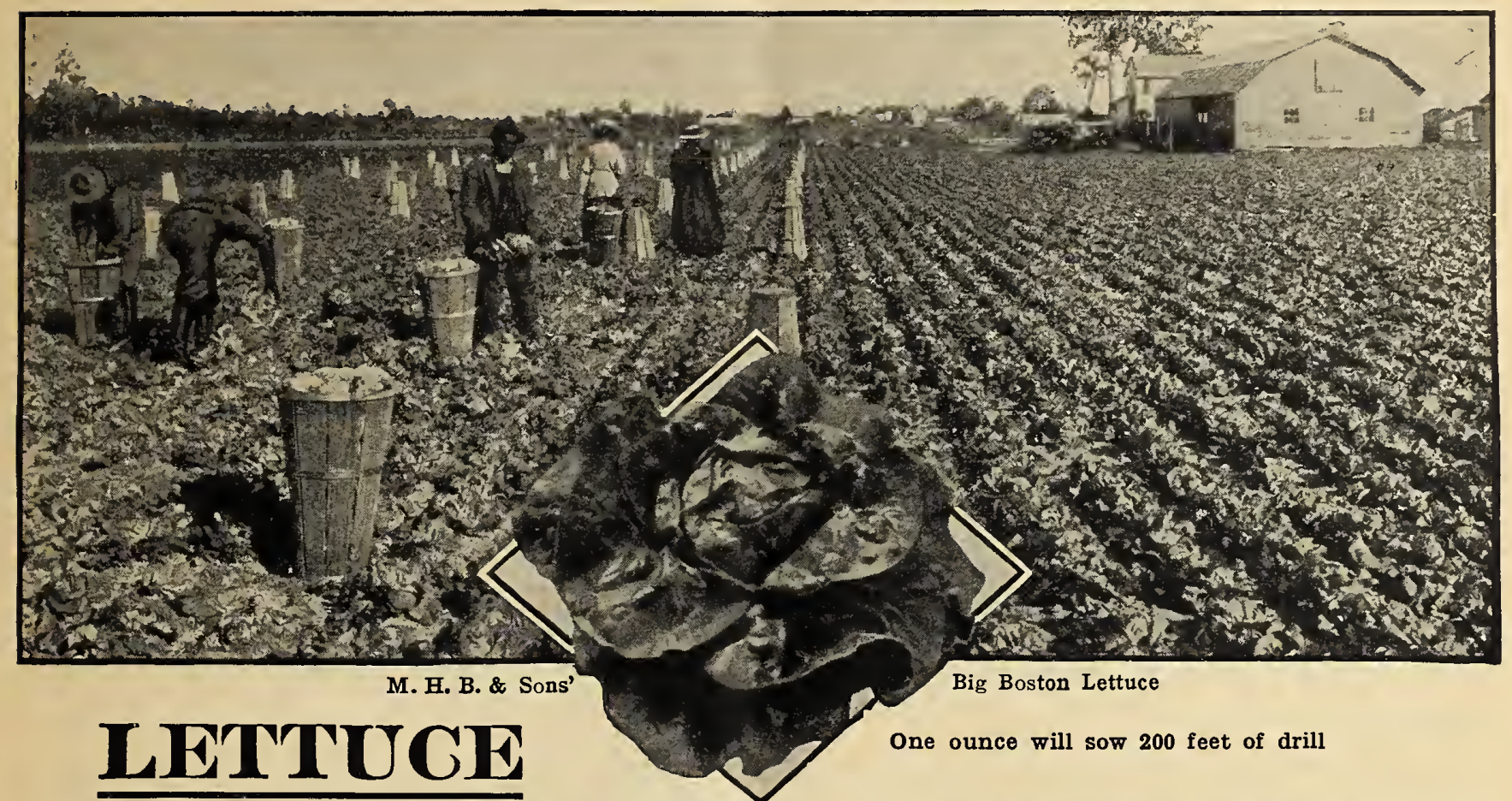

Early Lettuce may be had by sowing seed in hotbeds during February or March, and transplanting to the open ground in May. Seed is sown outdoors from April to August in drills 12 inches apart and later thinned out to 10 inches in the row. Select a rich, moist soil if possible, as the quality of Lettuce depends largely upon how quickly it grows.

M. H. B. \& Sons' Big Boston. This splendid Lettuce has popular for early spring and fall sowing. The large, solid heads are light green in color, slightly tinged with brown. We can recommend our stock to be the best procurable anywhere. Pkt. 5 cts., oz. 20 cts., $\frac{1}{4}$ lb. 50 cts., lb. $\$ 1.50$.

Big Boston, Black-seeded. Quite similar to our white-seeded Big Boston, but the heads grow somewhat larger. It is most valuable for sowing in the fall, but we do not recommend it so well for the spring. Pkt. 5 cts., oz. 20 cts., $\frac{1}{4}$ lb. 60 cts., lb. $\$ 2$.

All Seasons. Well adapted for growing in summer for which it is principally used. Globular, well-blanched heads which stand long before running to seed. Pkt. 5 cts., oz. 15 cts., $\frac{1}{1}$ lb. 40 cts., lb. $\$ 1.25$.

Black-seeded Simpson. The plants form a mass of long leaves, of excellent flavor, exceedingly tender and crisp; light green shading almost white. Fine for summer use. Pkt. 5 cts., oz. 15 cts., $\frac{1}{4}$ lb. 40 cts., lb. $\$ 1.25$.

Boston Market (White-seeded Tennisball). An early, medium-sized Lettuce suited to growing in frames and also for forcing. Pkt. 5 cts., oz. 15 cts., $\frac{1}{4}$ lb. 40 cts., lb. $\$ 1.25$.

Brown Dutch. Well adapted to southern culture, especially in the fall months, when it may be treated as a winter Lettuce. Pkt. 5 cts., oz. 15 cts., $\frac{1}{4} \mathrm{lb} .40$ cts., lb. $\$ 1.25$.

California Cream Butter. Its soft, thick leaves form large, globular heads of a rich cream-yellow, very solid and of sweet buttery flavor. Pkt. 5 cts., oz. 15 cts., $\frac{1}{1}$ lb. 40 cts., lb. $\$ 1.25$.

Early Curled Simpson. It is not only very early but one Its bright green, curly leaves are tender and of a delicate flavor. Pkt. 5 cts., oz. 15 cts., $\frac{1}{4}$ lb. 40 cts., lb. $\$ 1.25$.

Hanson. Succeeds in almost any soil and forms large, solid heads, somewhat crumpled, at all seasons. Recommended for private gardens. Pkt. 5 cts., oz. 15 cts., $\frac{1}{4}$ lb. 40 cts., lb. $\$ 1.25$.

Iceberg. The leaves of this Lettuce are beautifully curled at the edges, crisp, brittle and bright green; very solid; well blanched. Pkt. 5 cts., oz. 15 cts., $\frac{1}{4}$ lb. 40 cts., lb. $\$ 1.25$.

Wayahead. Highly recommended for sowing early in coldframes or outdoors in spring, summer or early fall. It grows rapidly, being one of the earliest Lettuces in our list, while the heads are solid and of the finest quality. Be sure to try it. Pkt. 5 cts., oz. 20 cts., $\frac{1}{4}$ lb. 50 cts., lb. $\$ 1.50$.
Mammoth Black-seeded Butter. Our customers should sowing of this grand Lettuce either in the spring or fall. The heads are of immense size, light green in color, but never tinged with brown; quality unsurpassed, being tender, crisp and sweet. Pkt. 5 cts., oz. 20 cts., $\frac{1}{4}$ lb. 50 cts., lb. $\$ 1.50$.

Market-Gardeners' Private Stock. An excellent summer Lettuce, the heart of which is well blanched, very tender and crisp. Pkt. 5 cts., oz. 15 cts., $\frac{1}{4}$ lb. 40 cts., lb. $\$ 1.25$.

May King. One of the leading varieties for forcing or early outdoor planting. It is of very quick growth, of particularly fine flavor and little affected by unfavorable weather. The heads are of good size, light green in color, the inner leaves blanching to a rich, golden yellow, and are very crisp and tender. Pkt. 5 cts., oz. 20 cts., $\frac{1}{4} 1$ b. 50 cts., lb. $\$ 1.50$.

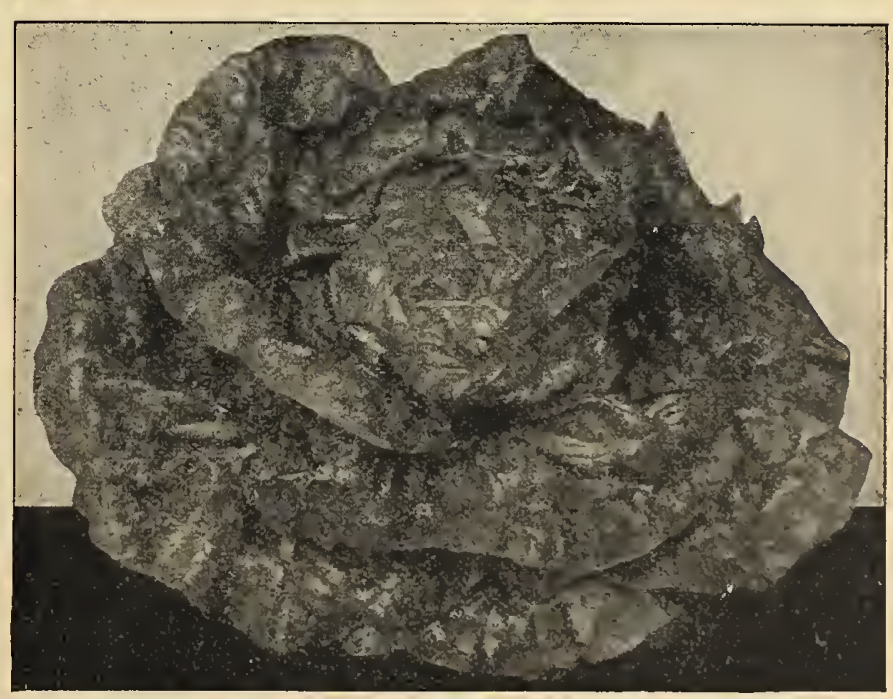

Lettuce, Mammoth Black-seeded Butter 


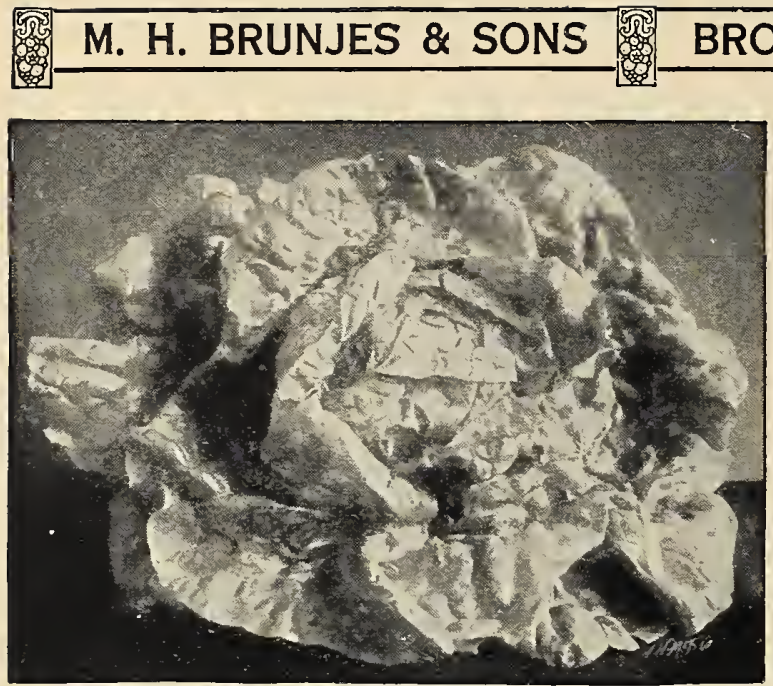

Lettuce, May King

\section{LETTUGE, continued}

New York, or Wonderful. The broad, dark green leaves are beautifully curled and fringed at the edges, while the heads are large, solid and very tender. Pkt. $5 \mathrm{cts}$., oz. $15 \mathrm{cts.}, \frac{1}{4} \mathrm{lb}$. $40 \mathrm{cts}$., $1 \mathrm{~b}$. $\$ 1.25$.

Prizehead. For those who prefer a leaf Lettuce, Prizehead will be found a most reliable variety. Leaves large and spreading, somewhat ruffled and exceptionally tender. Easily grown. Pkt. 5 cts., oz. 15 cts., $\frac{1}{4} \mathrm{lb}$. 40 cts., lb. $\$ 1.25$.

M. H. B. \& Sons' Salamander. A superb and undoubtedly the Lettuce. Heads are well formed, compact, light green in color and unsurpassed in quality. Pkt. 5 cts., oz. 15 cts., $\frac{1}{1}$ b. 40 cts., lb. $\$ 1.25$.

Tennisball Black-seeded. Comparatively few possess the good qualities of this sort, which may be planted at all seasons, but is especially desirable during the warm weather. Heart blanches readily and has a rich buttery flavor. Pkt. 5 cts., oz. 15 ct.s., 1 lb. 40 cts., lb. $\$ 1.25$.

Unrivaled. Similar in almost every way to Big Boston, except that the color is solid green without any tinge of brown whatever. Pkt. 5 cts., oz. 25 cts., $1 / 4$ lb. 75 cts., lb. $\$ 2.50$.

Yellow-seeded Butter. An ideal Lettuce for the home garden. forming a solid head which is tender, crisp and of excellent quality. Pkt. 5 cts., oz. 15 cts., $\frac{1}{4}$ lb. 40 cts., lb. $\$ 1.25$.

LETTUGE PLANTS. See page 28

\section{ROMAINE, or GOS LETTUCE}

M. H. B. \& Sons' Mammoth White Cos. $\begin{gathered}\text { F o r m s } \\ \text { very large }\end{gathered}$ oblong heads, well rounded at the top; light green in color and of excellent quality. Pkt. 5 cts., oz. 25 cts., $1 / 4$ lb. 75 cts., lb. $\$ 2.50$.

Eclipse Cos. Dwarf in growth and matures very early. Leaves grow upright, are erisp and very tender. Pkt. 5 cts., wz. 20 cts., 1lb. 50 cts. lb. $\$ 1.50$.

Paris White Cos. This variety is becoming more popular every year. The outer leaves are dark green, while the inner ones closely overlap each other, forming a handsome, wellblanched head of creamy white. Pkt. 5 cts., oz. 15 cts., 1 lb. 40 cts., lb. $\$ 1.25$.

For succession sow: spring, Mammoth Black-seeded Butter; summer, M. H. B. \& Sons' Salamander; fall, M. H. B. \& Sons' Big Boston.

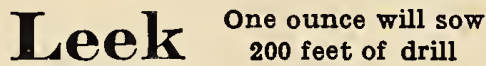

One of the three vegetables principally used for flavoring soup. Both for summer and winter use sow seed during April and May in drills $\frac{1}{2}$ inch deep, and when quite strong, usually the early part of July, transplant in rows 12 inches apart and 5 inches apart in the row. Plants should be slightly trimmed before setting out. Large American Flag. The best variety for the home garden.

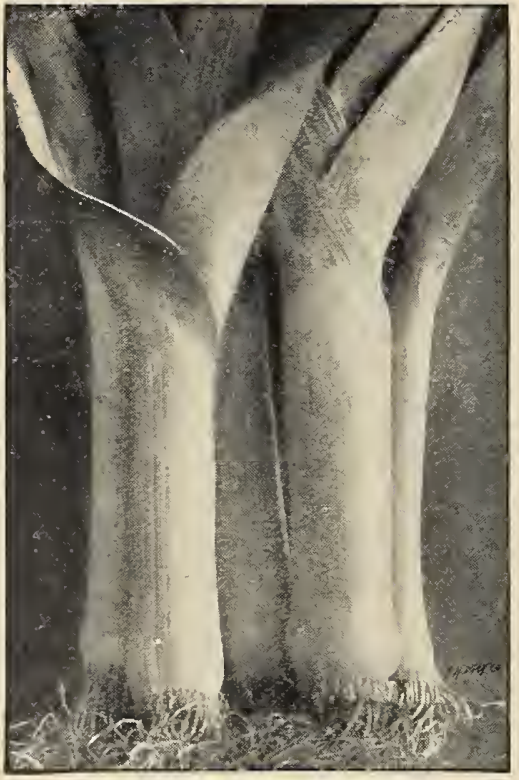

Leek, Large American Flag Early, very large and withstands considerable cold weather, though it is mostly grown for summer and early fall. Pkt. 5 cts. oz. 20 cts., $\frac{1}{4}$ lb. $65 \mathrm{c}$., lb. $\$ 2.25$.

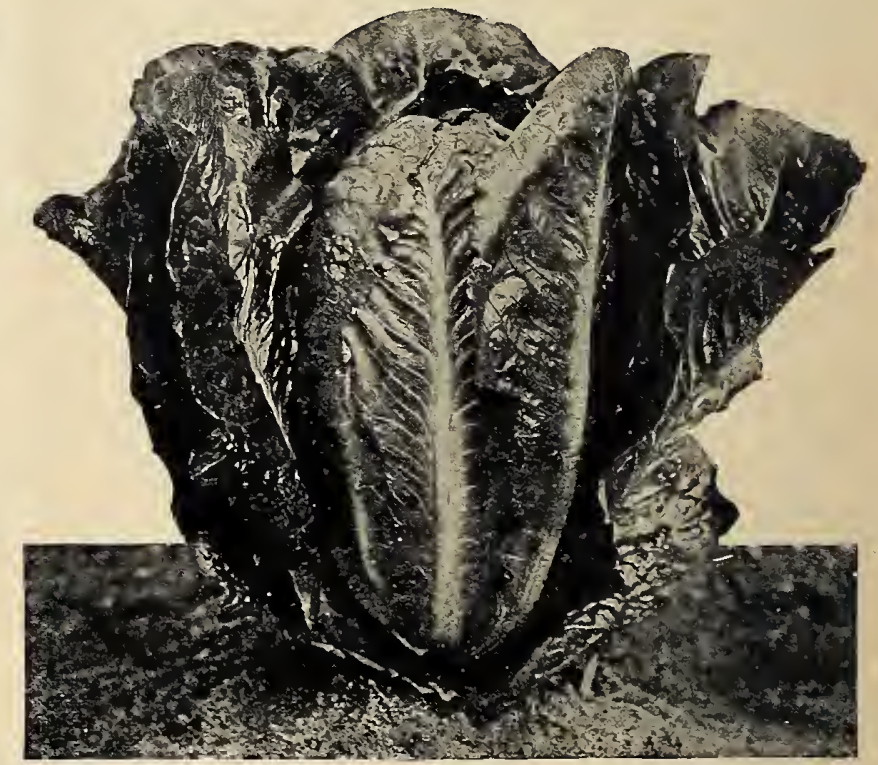

Lettuce, Paris White Cos

Brunjes' Winter. Can be left to stand outdoors during the winter and will remain in fine condition until the following spring. Very solid and firm, but not quite so large as the preceding. Pkt. 5 ets., oz. 30 cts., $\frac{1}{4} \mathrm{lb} .90$ cts., lb. $\$ 3.25$.

\section{MUSTARD one ounce will sow 75 feet of drill}

The leaves impart a sharp, pungent flavor to salads and are also highly esteemed when cooked like spinach. For a succession, sow seed $\frac{1}{2}$ inch deep, in drills 8 inches apart, every few weeks from early spring until September.

Giant Southern Curled. Leaves are large, finely curled and form a good substitute for spinach. Pkt. 5 ets., oz. 10 cts., $\frac{1}{4}$ lb. 25 ets., lb. 75 cts.

White English. The best for salad; grows rapidly. Pkt. 5 cts., oz. 10 cts., $\frac{2}{4} l b .25$ cts., lb. 75 cta.

\section{NASTURTIUM one ounce will sow 20 feet of drill}

Although the Nasturtium is grown principally for its flowers, the green seeds when pickled may be used as a substitute for capers. Sow the seed 1 inch deep, usually about the beginning of May.

Tall Mixed. Requires the support of a trellis or fence. Pkt. 5 cts., oz. 15 cts., $\frac{1}{4}$ lb. 50 cts.,

lb. $\$ 1.50$.

Dwarf Mixed. Pkt. 5 cts., oz. 15 cts., allb. 50 cts., lb. $\$ 1.50$. 


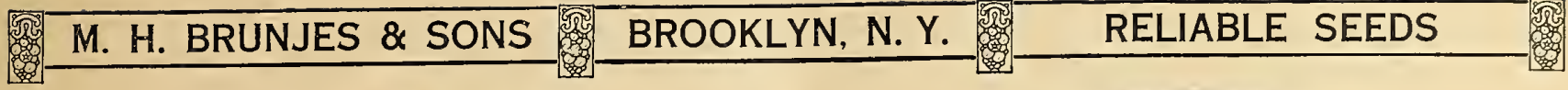

\section{MUSKMELON}

One ounce will plant 60 hills

A light, rich soil is preferred for growing Melons. In May, when the soil has become warm and dry, plant 8 to 10 seeds $\frac{1}{2}$ inch deep in hills 5 to 6 feet apart each way. Before planting add a quantity of well-rotted manure to each hill and mix thoroughly. Like cucumbers and squash, the young plants should be protected from insects and for this purpose a dusting of tobacco dust is advisable. As soon as the plants begin crowding and after the danger from insects is past, remove all but 3 plants to a hill. The side runners should be pinched back to insure fruiting. Spray at intervals with Bordeaux Mixture, to which a small quantity of arsenate of lead has been added.

Rocky Ford. One of the finest basket Melons in cultivation, vigorous and continuous bearers; oval fruit having thick, green flesh of excellent quality. Splendid either for the private gardener or shipper. Pkt. 5 ets., oz. 15 ets., $\frac{1}{4}$ lb. 40 ets., lb. $\$ 1.25$.

Gold-lined Rocky Ford. We feel sure our customers will be pleased with Gold-lined Rocky Ford. It is slightly oval in shape, no ribs, and heavily netted over the entire melon. The flesh is thick, finegrained and deliciously sweet; color green with a gold margin next to the seed-cavity. Pkt. 5 cts., oz. 20 cts., $\frac{1}{4}$ lb. 60 cts., lb. $\$ 2$.

Burrell's Gem. An ideal variety for the garden and especially desirable for shipping. Medium size, averaging 2 to $2 \frac{1}{4}$ pounds each; oval in shape, with thin, hard rind and dark green, closely netted skin. The unusually thick, salmon-red flesh is fine-grained and possesses a rich, spicy flavor. Pkt. 5 cts., oz. $15 \mathrm{cts}$., $\frac{1}{4} \mathrm{lb} .40 \mathrm{cts}$., lb. $\$ 1.25$.

Emerald Gem. A favorite early sort of the finest quality. The green, while the flesh, of salmon color, ripens almost to the rind and is the sweetest of any. Pkt. 5 cts., oz. 15 cts., $\frac{1}{6}$ lb. 40 cts., lb. $\$ 1.25$.

Extra-early Hackensack. This is a popular-green-fleshed variety with large, heavily netted fruit. Good for shipping. Pkt. 5 cts., oz. 15 cts., $\frac{1}{4}$ lb. 40 cts., lb. $\$ 1.25$.

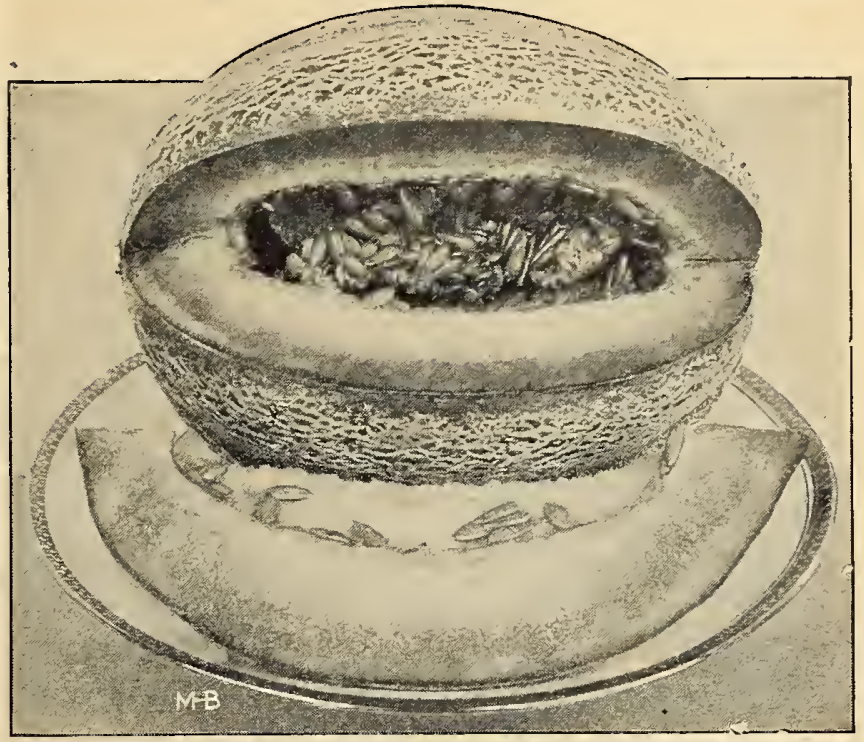

Muskmelon, Rocky Ford

Hoodoo. This grand new Melon is highly recommended either for the home table or for shipping. It is uniform in size, nearly round, heavily netted, while the flesh is very thick, exceedingly sweet, and rich orange in color. Pkt. 5 cts., oz. 15 cts., $\frac{1}{4} l$ b. 40 cts., lb. $\$ 1.25$.

Honey Dew. A new type of Muskmelon with ovoid shaped fruit about 10 inches long and 8 inches in diameter. The skin is hard and smooth, creamy yellow in color and the thick flesh of light emerald green is unusually sweet and melting. Pkt. 10 cts., oz. 25 cts., $\frac{1}{4}$ lb. 75 cts., lb. $\$ 2.50$.

\section{WATERMELONS}

Ono ounce will plant 40 hills

Culture similar to that of muskmelon, excepting the hills should be 8 to 10 feet apart.

Alabama Sweet. Popular among the southern growers. Long and very large, with dark green rind and bright red flesh of excellent quality. Pkt. 5 cts., oz. 10 cts., $\frac{1}{4}$ lb. 30 ets., lb. 90 cts.

Harris' Earliest. An early, oval-shaped variety with deliciously Pkt. 5 cts., oz. $10 \mathrm{cts}$., $\frac{1}{4} \mathrm{lb} .30 \mathrm{cts}$., lb. $90 \mathrm{cts}$.

Kolb's Gem. Very large, and owing to its hard, firm rind it is used extensively for shipping. Pkt. 5 cts., oz. 10 cts., $\frac{1}{4} \mathrm{lb} .30 \mathrm{cts.}$, lb. $90 \mathrm{c}$.

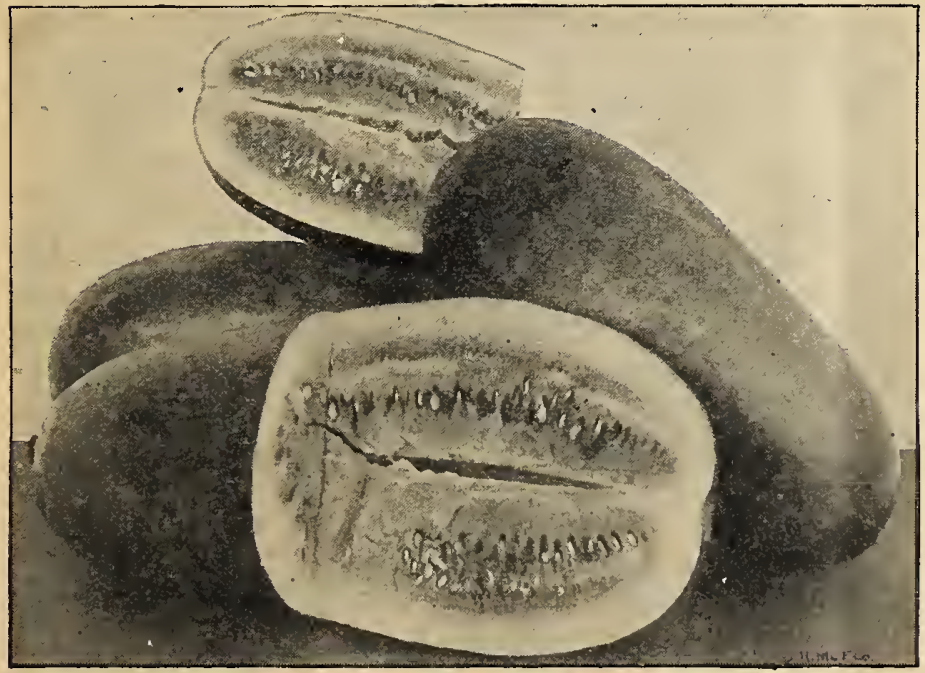

Watermelon, Kleckley Sweets
Kleckley Sweets. Medium to large size, oval in form, and un ceptionally fine for the private garden. Pkt. 5 cts., oz. 10 cts. $\frac{1}{6}$ lb. 30 cts., lb. 90 cts.

Sweetheart. The fruit is light green striped darker, oval and melting flavor. Pkt. 5 cts., oz. $10 \mathrm{cts}$., $\frac{11 \mathrm{l}}{4} \mathrm{~b} .30 \mathrm{cts}$., lb. $90 \mathrm{cts}$.

Citron, Red-seeded. Round and smooth; flesh white, used only for preserving. Pkt. 5 cts., oz. 10 cts., $\frac{1}{4}$ lb. 30 cts., lb. 90 cts.

\section{Mushroom Spawn}

Ten pounds will spawn 10 feet square

To grow Mushrooms does not necessarily require any special house, as a cellar, shed, or even under greenhouse benches will answer the purpose. Of course, conditions must be such that an even temperature of 50 to 65 degrees can be maintained. Secure some fresh horse manure, not too coarse, and also a quantity of good, rich soil. To 1 part of soil add 2 or 3 of manure, and when thoroughly mixed, form into beds 3 feet wide, and from 10 to 12 inches deep, pounding it together as you proceed. The bed will soon become very hot and not until temperature rccedes to 80 or 90 degrees is it ready tor the spawn. Make holes 8 to 10 inches apart and large enough to admit the spawn, which is to bc broken into picecs the size of a hen's egg and covered $1 \frac{1}{2}$ inches. After remaining in this condition from 8 to 10 days, cover the bed with 2 inches of fresh soil and after firming with the back of a spade cover with 4 inches of salt hay or straw. It takes about 2 months bcfore the first Mushrooms appear. When watering, the water should be about 95 dcgrecs.

English Spawn. (In bricks.) Pcr brick, 25 cts.; 12 bricks, $\$ 2.75$. Pure-Culture. (In bricks.) Per brick, 35 cts.; 12 bricks, $\$ 4$.

By mail, add postage at zone races. One brick weighs $1 \frac{1}{2} \mathrm{lbs}$. 


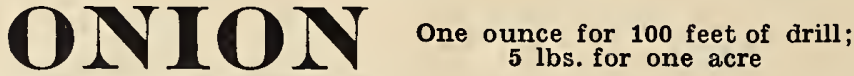

A rich loamy soil, preferably one that has been liberally manured the previous season, is best suited to growing Onions. Just as soon as the soil is in workable condition, usually in April, sow seed 1 inch deop in drills 12 inches apart, and later thin out the plants to 4 inches apart in the row. Hoe frequently and also give occasional weeding. Our Onion seed is raised from selected bulbs and no better stock can be obtained at any price.

\section{Three of the Finest Onions}

Southport White Globe. Owing to its beautiful white skin; pearance, it has become a favorite with all. abundant yielder, with firm, mild fiesh. Pkt. 5 cts., oz. 30 cts., $\frac{1}{4}$ lb. 90 cts., lb. $\$ 3.25$.

Southport Red Globe. A medium-early variety with large very small neck and deep, purplish red color; flesh tender and of excellent quality. Extensively grown both for market and private use. Pkt. 5 ets., oz. 25 cts., $\frac{1}{4}$ lb. 75 cts., lb. $\$ 2.75$.

Southport Yellow Globe. Large Onion of globular form, color. It matures about the same time as Southport Red Globe and has flesh of the same high quality. Excellent keeper. Pkt. 5 cts., oz. 25 cts., $\frac{1}{4}$ lb. 75 cts., lb. $\$ 2.50$.

Adriatic Barletta. The small, round, snow-white bulbs mature very early and are prized for pickling. Pkt. 5 cts., oz. 25 cts., $\frac{1}{4}$ lb. 75 cts., lb. $\$ 2.75$.

Ailsa Craig. An exceptionally large Onion and one of the finest for exhibiting. It is oval-shaped, slightly pointed at each end, with pale, straw-colored skin and solid white flesh. To obtain extra-large specimens, sow seed in hotbeds during February and transplant to the open ground in April. Pkt. 10 cts., oz. 40 cts., llb. $\$ 1.25$, lb. $\$ 4$.

Hardy White Winter. The seed should be sown during the latter part of August, or beginning of September, and the plants left standing over winter. In this way, pure white, fat-shaped Onions of medium size may be had from three to four weeks earlier than seed sown in spring. Pkt. 5 cts., oz. 30 cts., $\frac{x}{4}$ lb. 90 cts., lb. $\$ 3.25$.

Large Red Wethersfield. Splendid deep red sort and fine flat but thick, with purplish white flesh of rather sharp flavor. One of the best main-crop varieties and grows best in rich, dry soil. Pkt. 5 cts., oz, 25 cts., $\frac{1}{4} l b .75$ cts., lb. $\$ 2.50$

Prizetaker. A very popular variety of enormous size, single bulbs often weighing from two to four pounds. Handsome, globularformed Onions with bright yellow skin and fine-grained flesh of the purest white. An immense cropper. Pkt. 5 cts., 0 \%. 25 cts., $\frac{1}{4} \mathrm{lb}$. 75 cts., 1b. $\$ 2.50$.

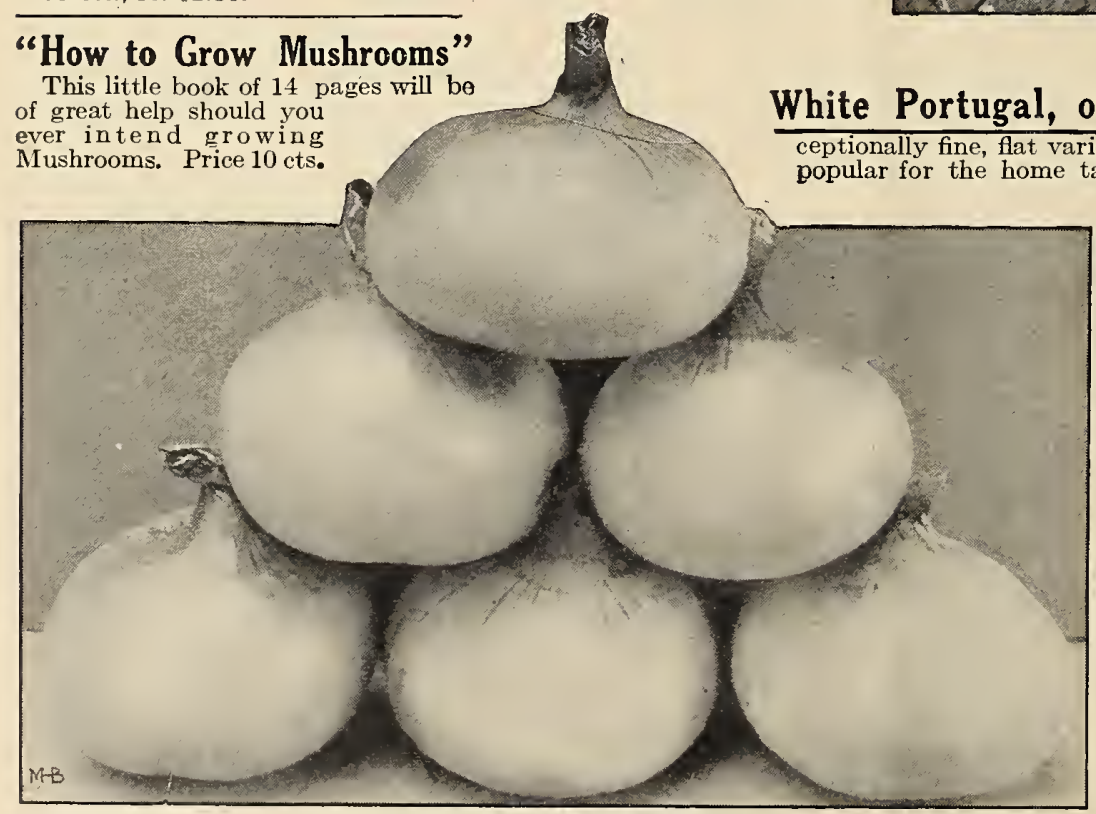

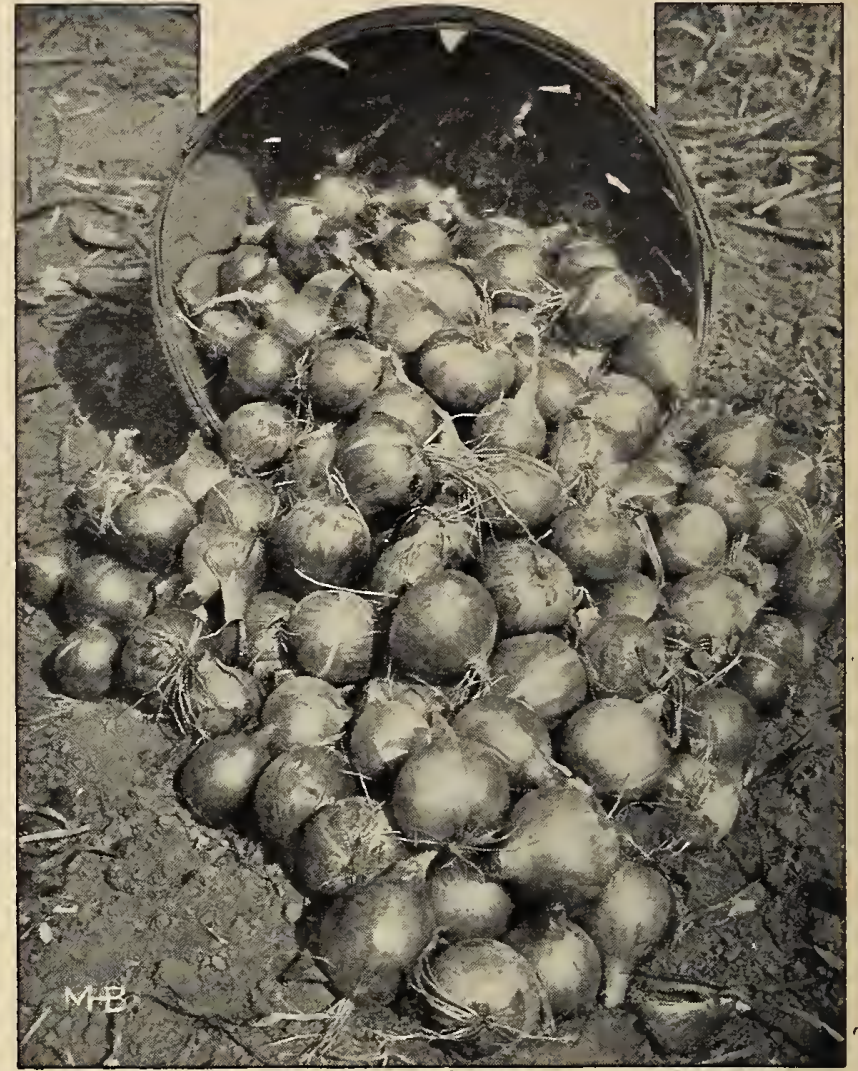

Onion, Yellow Globe Danvers
Onion, White Portugal This little book of 14 pages will be
oreat help should you

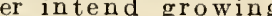

White Queen. One of the best early varieWhite Queen. ties for the garden. The bulbs, which are ready for use about the same time as Adriatic Barletta, are of the purest white, almost round and measure from 1 to 2 inches in diameter. It is especially desirable for pickling and looks very attractive when bunched for the market. Pkt. 5 cts., oz, 25 cts., $\frac{1}{4}$ lb. 75 cts., lb. $\$ 2.75$.

White Scullion. Similar in growth to the Leek, growing straight and not forming any bulb. Sow the seed during August and they will be ready for the table in early spring. Used only in the green state. Pkt. 5 cts., oz. 25 cts., 1lb. 75 cts., lb. $\$ 2.75$.

Yellow Globe Danvers. Especially recYellow Globe Danvers. ommended as one of the best yellow sorts, and there are many who will have no other. In shape it is nearly round with light brown-colored skin and solid white flesh. It is a heavy cropper, noted for its superior keeping qualities, and is extensively grown by both market and private gardeners for winter storing. Pkt. 5 cts., oz. 25 cts., $\frac{1}{4}$ lb. 75 cts., lb. $\$ 2.50$. 


M. H. BRUNJES \& SONS

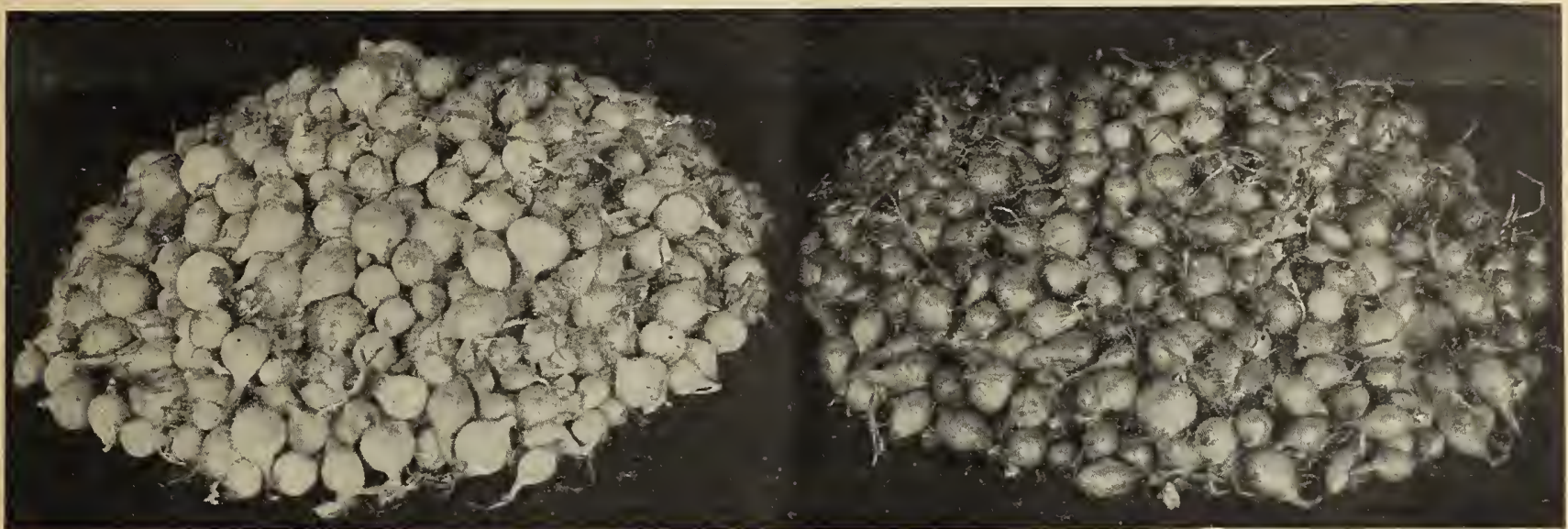

White Onion Sets

Yellow Onion Sets

\section{ONION SETS}

By planting sets, Onions may be had much earlier than from spring-sown seed. To obtain large Onions sets should be planted 3 to 4 inches apart, in rows 1 foot apart, as soon as the frost is out of the ground.

If by parcel post, add postage at zone rate. $1 \mathrm{qt}$. weighs $11 / 4 \mathrm{lbs}$.

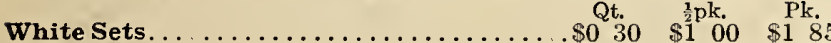

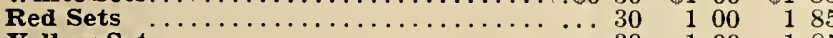

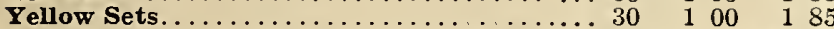

Egyptian, or Top Onion. Produces small bulbs on top of stalks, which are planted in autumn and used in the spring as scullions. Ready in August. Qt. 25 cts., $\frac{1}{2}$ pk. 90 cts., pk. $\$ 1.60$.

\section{OKRA, or GUMBO}

\section{One ounce will sow $\mathbf{4 0}$ feet of drill}

Extensively grown in the South. The green pods are used in soups, Sow during May in drills 3 feet apart, and later thin out to 10 inches in the row.

White Velvet. Pods are round, smooth, white and tender. Pkt. 5 cts., oz. 10 cts., $\frac{1}{4}$ lb. 20 cts., lb. 65 cts.

Perkins Mammoth Long. Pod. Wonderfully productive; immense, deep green pods, slim but retaining their tenderness longer than most sorts. Pkt. 5 cts., oz. 10 cts., tilb. 20 cts., lb. 65 cts.

\section{PRICES ON SEED POTATOES}

We shall be pleased to quote our lowest prices on the varieties of Seed Potatoes we have listed

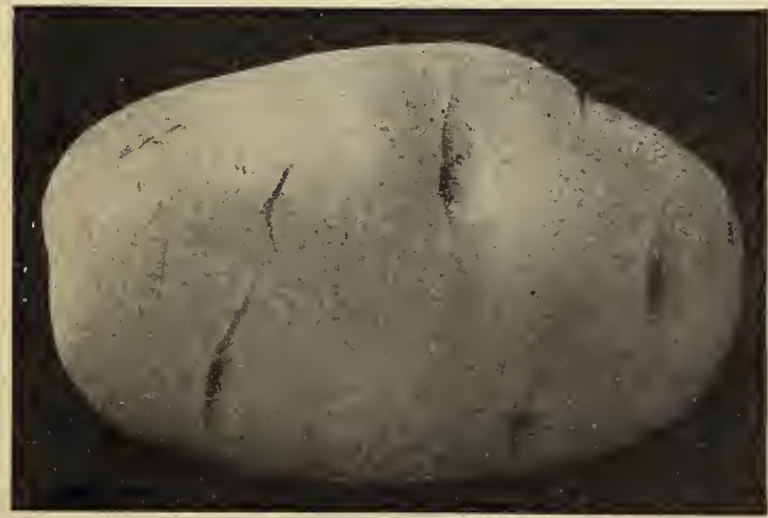

Potato, Green Mountain

\section{SEED POTATOES}

Ten bushels cut tubers will plant one acre; one peck will plant 125 hills

\section{Ghoice Maine-Grown Stock}

Our seed Potatoes are especially grown for seed purposes and can be depended upon for best results. Planting may commence as early in the spring as the ground can be worked. Place one piece every 12 inches in rows $2 \frac{1}{2}$ feet apart, covering about 4 inches. When cutting the seed, care should be taken to allow at least one good eye, or two small ones, to each piece. A spraying of Paris green or arsenate of lead prevents the ravages of the potato bug.

Important. Potatoes may be sent by express or freight, according to quantity, at purchaser's expense. Our sacks contain 165 pounds.

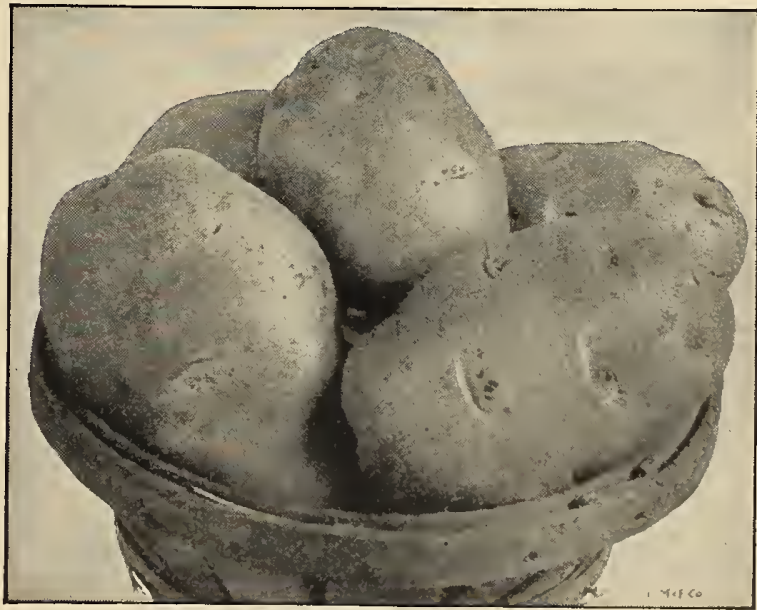

Potatoes, Early Rose

Early Rose. Although one of the older varieties, this well-known and very popular Potato is still among the most largely planted for the home garden. It matures carly, is a good cropper and one of the best in quality.

Green Mountain. This variety is most extensively grown on Long Island and is undoubtedly the best and It is an immense cropper, wonderful keeper, and one of the finest cooking varieties.

Irish Cobbler. Equally popular both with market-gardencrs and also for planting in the home-garden. It is not only one of the carliest but can usually be depended upon to produce a good yield of ten from 300 to 350 bushels to the acre. A large, handsome Potato of uniform shape; flesh white and of finc flavor. A profitable variety to plant. 


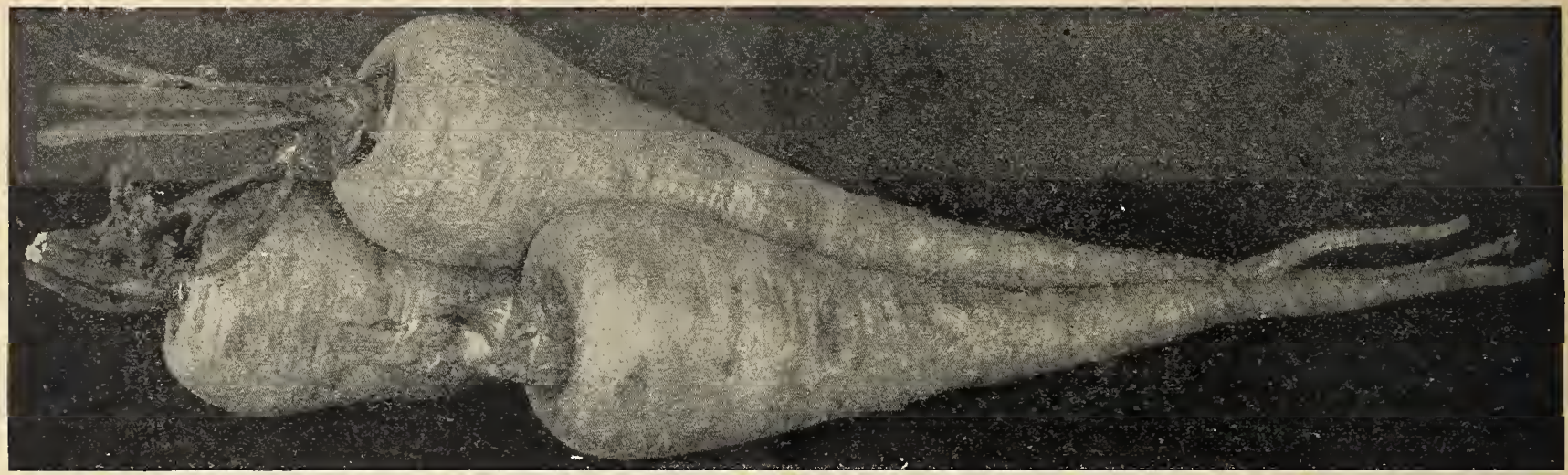

Parsnip, M. H. B. \& Sons' Hollow Crown

\section{Parsnip}

Parsnips require a deep, rich, mellow soil, and should be sown in drills $1 \frac{1}{2}$ feet apart and $\frac{1}{2}$ inch deep as soon as the ground can be worked in spring. Thin plants to 6 inches apart in the row and cultivate frequently. Like Brussels sprouts and kale, their flavor is improved after a hard frost.

M. H. B. \& Sons' Hollow Crown. There is no finer Parsnip grown variety. It has long, smooth, clear white roots of the finest flavor and is an immense cropper. We have a very choice stock of this variety. Pkt. 5 cts., oz. 10 ets., $\frac{1}{4}$ lb. 30 cts., lb. $\$ 1$.

\section{Parsley}

As the seed is slow in germinating, it should be sown as early in spring as possible in drills 1 foot apart and $\frac{x}{2}$ inch deep. When the plants are well advanced thin out to 6 inches apart in the row. By making a second sowing, under glass, in July or August, a supply can he had throughout the winter.

Extra Double Curled. Tnis is an exceptionally fine strain of double curled Parsley, and one that may be depended upon for

best results either for the frame or outside sowing. The leaves are of handsome

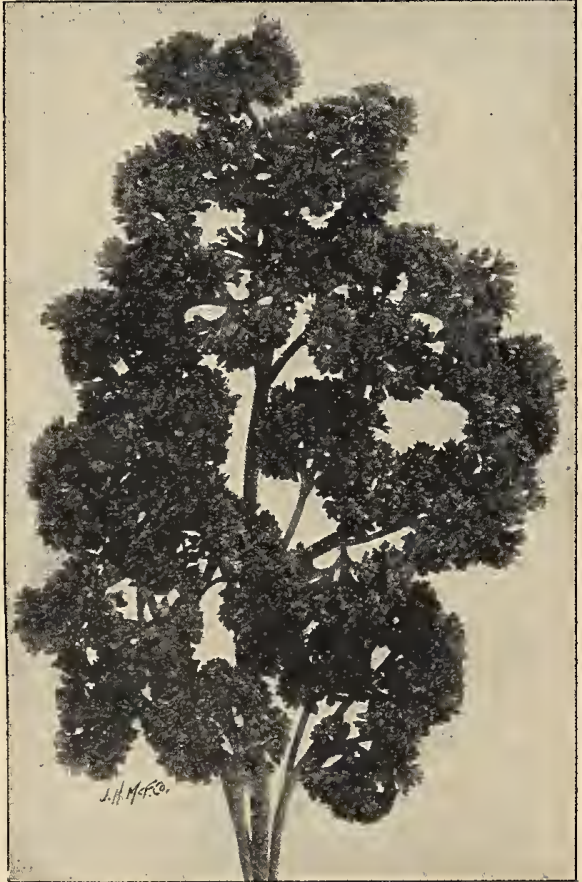

Parsley, Extra Double Curled appearance, deeply curled, very dark green in color and unequaled for flavoring and garnishing. It withstands the extreme heat and drought of summer better than most varieties and it has also proved to be the best variety for fall or winter use. Pkt. 5 c., oz. 15 c., $\frac{1}{4}$ lb. 40 c., lb. $\$ 1.25$.

Champion Moss Curled. A fine, curly variety, resembling the above in appearance, but of more rapid growth. Pkt. 5 cts., oz. $15 \mathrm{c}$., $\frac{2}{4}$ lb. 40 cts., lb. $\$ 1.25$.

Plain. Leaves are not curled, and have an excellent flavor: preferred by many. Pkt. 5 cts., oz. 15 cts., $\frac{1}{4} \mathrm{lb} .40$ cts., lb. $\$ 1.25$.

Turnip-rooted, or Hamb urg. The roots, which resemble small Parsnips, are valuable for flavoring soups, while the leaves, similar to those of celery, may also be used for the same purpose. The roots may be dug in the fall and stored in the cellar, or they may be left standing outdoors through the winter for use in early spring. Pkt. 5 cts., oz. 15 cts., $\frac{1}{4}$ lb. 40 cts., lb. $\$ 1.25$.

\section{PEPPER PLANTS}

\section{Dempere One ounce will produce}

Peppers should be started in a hotbed during March or April. The latter part of May transplant to the oper ground in rows 2 feet apart and 18 inches in the row.

Chinese Giant. An unusually large sweet Pepper Nose, but a little later in maturing. The flesh is quite thick, very mild and of a bright red color. Plants 2 feet high and very productive. Pkt. $10 \mathrm{cts}$., oz. 60 cts., $\frac{1}{4}$ lb. $\$ 2.25$, lb. $\$ 8$.

Large Bell, or Bull Nose. Plant of vigorous large thick Peppers of mild flavor. Pkt. $10 \mathrm{cts.}$ $0 z, 50$ cts., $\frac{1}{3} l b . \$ 1.60,1 b, \$ 6$.

Giant Crimson. The earliest and most productive of the very large Peppers. Fruit of immense size, thick fieshed, mild and very sweet. Pkt. $10 \mathrm{cts}$., oz. $60 \mathrm{cts.,}$ $\frac{1}{4}$ lb. $\$ 2.25$, lb. $\$ 8$.

Pimiento. The sweetest Pepper grown and largely used either for salads or filling. When fully matured the heart sinaped fruit is bright red, very smooth and of good size. Pkt. 10 cts., oz. 60 cts., $\frac{1}{4}$ lb. $\$ 2.25,1$ b. $\$ 8$.

Long Red Cayenne. The bright scarlet pods, varying from 3 to 4 inches, in length are very pungent. Pkt. 10 cts., oz. 50 cts., $\frac{1}{4}$ lb. $\$ 1.50$, lb. $\$ 5$.

Chili. A late-maturing variety with small red fruit, which is used extensively for pepper sauce. Pkt. 10 ets., oz. 50 cts., $\frac{1}{4}$ lb. $\$ 1.50,1 b . \$ 5$.

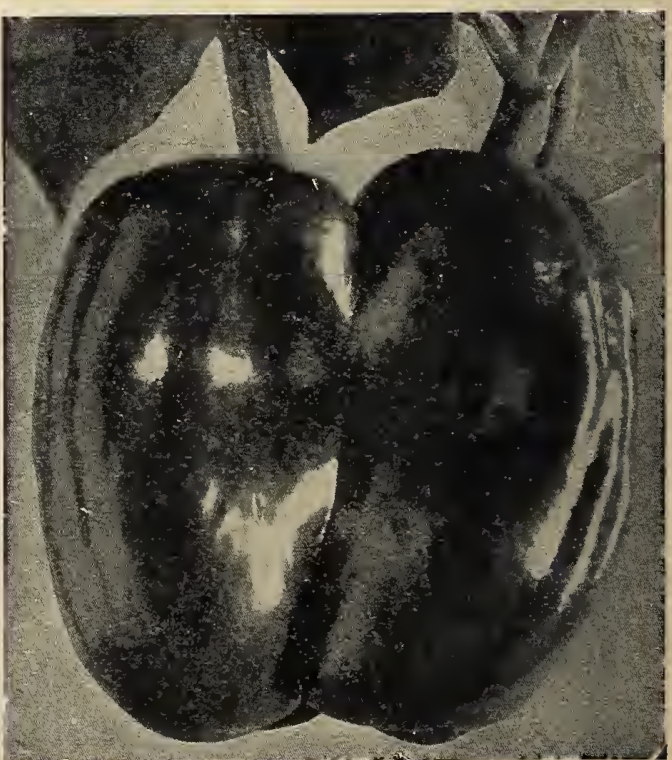

Pepper, Chinese Giant 
All smooth-seeded Peas may be planted as early in spring as the soil can be prepared for them. They are very hardy, and will endure a low temperature, both before and after sprouting. By sowing for the first crop as early as practicable, and for succession at intervals of about two weeks until the first of June, a good supply of this delicious vegretable may be enjoyed through the greater part of the summer. Late sowings, however, do not yield so well as early ones, because the hot and dry weather is unfavorable to the development of the plants. The seed should be sown in drills about 3 inches deep and from 3 to 4 feet apart, according to the variety, taller sorts requiring more room than the dwarf ones. Dwarf Peas require a very rich soil, while tall ones thrive best in rather thin ground, which does not stimulate too luxuriant growth in the vines, to the detriment of the pods. The latter are frequently sown in double rows, with the brush or support of some kind between them. Wrinkled Peas are not so hardy as the smooth sorts, and should not be sown so early, but are superior to them in quality, more delicate in flavor, and remain longer in season.

\section{IF BY PARCEL POST, ADD POSTAGE AT ZONE RATES}

\section{EXTRA-EARLY}

First of All. An extremely early variety of vigorous growth, usually attaining a height of $2 \frac{1}{2}$ feet and bearing small-podded Peas of fair quality. $\frac{1}{2} \mathrm{lb} .25 \mathrm{cts}$., lb. 50 ets., 2 lbs. 95 cts., 10 lbs. $\$ 4.50$.

Alaska. Popular among market-gardeners for an early erop. The pods are medium size, dark green in color and ripen almost at one time. $\frac{1}{2} \mathrm{lb} .20$ ets., lb. 40 cts., 2 lbs. 75 cts., 10 lbs. $\$ 3.50$.

Ameer. The vines of this variety grow about 3 feet high and are heavy bearers. The pods, 3 inches long, mature shortly after Alaska and are well filled with sweet, tender Peas. $\frac{1}{2}$ lb. 20 cts., lb. 40 cts., 2 lbs. 75 cts., 10 lbs. $\$ 3.50$.

Little Marvel. This is without doubt the finest of the extra-early varieties. The plants are of dwarf habit, not exceeding 18 inches, immensely productive, bearing pods of good size and dark green color which contain six or seven Peas of excellent flavor. A gem for the home-garden and a profitable variety for the market-gardener. $\frac{1}{2}$ lb. 25 cts., lb. 50 cts., 2 lbs. 95 cts., 10 lbs. $\$ 4.50$.

Nott's Excelsior. One of the best dwarf, early, wrinkled Peas. It grows about generally contain six or seven large, sweet Peas of the finest quality. Well recommended for home use. $\frac{1}{2} \mathrm{lb}$. $20 \mathrm{cts}$., lb. 40 cts., 2 lbs. 75 cts., $10 \mathrm{lbs}$. $\$ 3.50$.

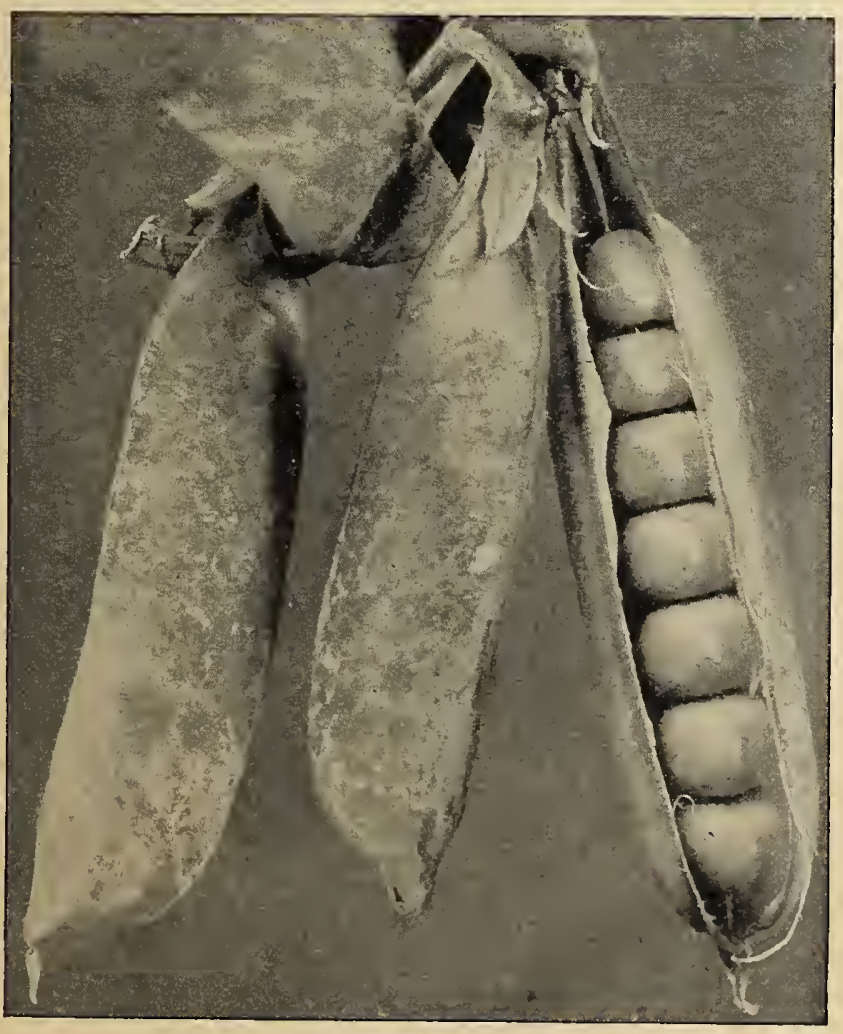

Peas, Nott's Excelsior

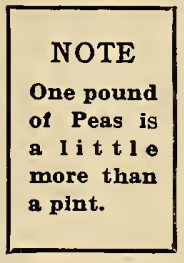

Premium Gem. The round pods, $2 \frac{1}{2}$ inches long, are borne on short bushes, which are well suited to small gardens, $\frac{1}{2}$ lb. 20 cts., lb. 40 cts., 2 lbs. 75 cts., 10 lbs. $\$ 3.50$.

American Wonder. Dwarfer and a trifle earlier than the preceding but not quite so productive. The Peas are sweet, tender and of delicious flavor. $\frac{1}{2} \mathrm{lb} .20$ cts., lb. 40 ets., 2 lbs. 75 cts., $10 \mathrm{lbs} . \$ 3.50$.

Sutton's Excelsior. This Pea is a great improvement over the other dwarf early varieties. It is a very heavy cropper and the large, handsome pods, uniform in size, are well filled with immense Peas of unsurpassed quality. Height 15 inches. $\frac{1}{2} \mathrm{lb} .20 \mathrm{cts}$., $\mathrm{lb}$. 40 cts., 2 lbs. 75 cts., 10 lbs. $\$ 3.50$.

Gradus. One of the most popular wrinkled sorts. Even though it patures a short time later than the extra-earlies, the pods, fully as long as those of the well-known Telephone, contain very large Peas that are unexcelled for sweetness. A superior variety for the market or private garden. $\frac{1}{2} \mathrm{lb} .25 \mathrm{cts}$., lb. $45 \mathrm{cts}$., 2 lbs. 85 cts., 10 lbs. $\$ 3.85$.

Thomas Laxton. Another exceedingly fine wrinkled variety Thomas Laxton. with broad pods, almost square at the ends, which measure from 4 to 5 inches in length. The Peas are of extralarge size, deep green in color and of the finest flavor. Although the pods do not ripen quite so early as those of the Gradus, the vines are a littlc more productive. Height 3 fcet. $\frac{2}{2} 1 \mathrm{~b} .25 \mathrm{cts}$., $1 \mathrm{~b}$. 45 cts., 2 lbs. 85 cts., 10 lbs. $\$ 3.85$.

Laxtonian. This new wrinkled Pea is very much like the wellLaxtonian. known Gradus in shape and size of pod but grows only about 15 inches high. It matures somewhat earlier than Gradus, is equally sweet, and is sure to bccome one of the leading early Peas for the garden. $\frac{1}{2} \mathrm{lb} .25$ cts., lb. 45 cts., 2 lbs. 85 cts., 10 lbs. $\$ 3.85$. 


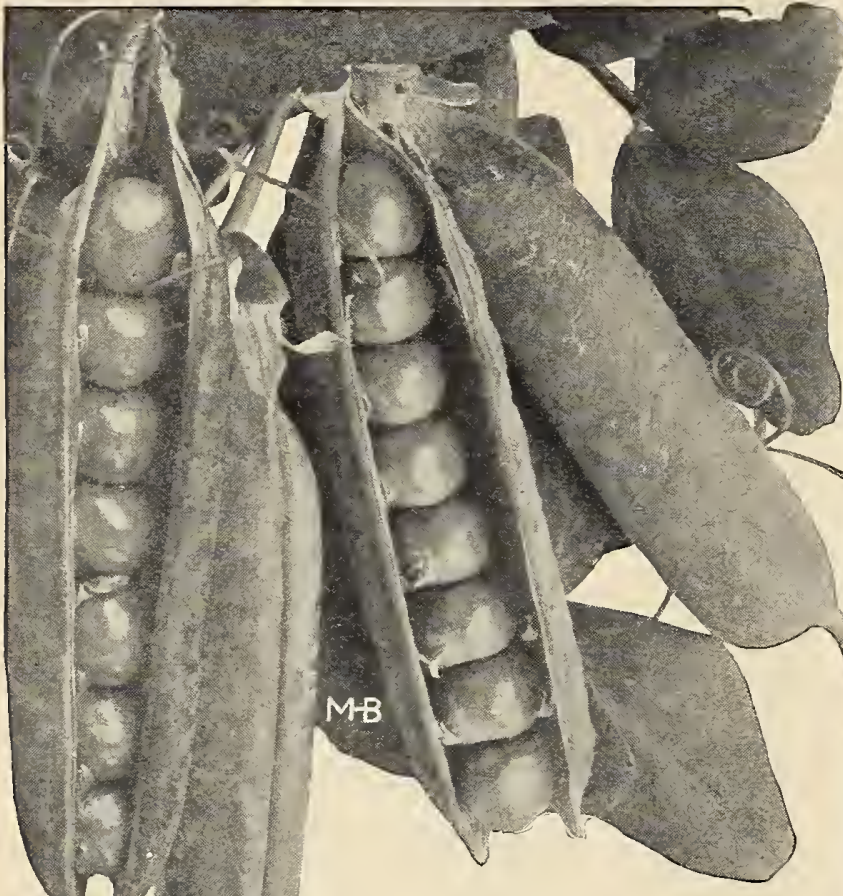

Champion of England. A standard Pea; vines grow $4 \frac{1}{2}$ feet high and bear medium-sized pods of Peas of good quality. $\frac{1}{2} \mathrm{lb} .25 \mathrm{cts}$., lb. 50 cts., 2 lbs. 95 cts., 10 lbs. $\$ 4.50$.

Duke of Albany. Immense pods, on style of Telephone; a Peas, Little dark green, well filled. Height 4 feet. $\frac{1}{2} \mathrm{lb} .20 \mathrm{cts}$., $1 \mathrm{~b} .40 \mathrm{cts}, 2 \mathrm{lbs} .75 \mathrm{cts}$., $10 \mathrm{lbs}$. $\$ 3.50$.

Tall Melting Sugar. The pods as well as the Peas of this variety are edible and are usually gathered before they are fully matured and cooked similar to snap beans. Pods average about 4 inches in length and when young are tender, stringless, and fine flavored. Height 4 to 5 feet. $\frac{1}{2} \mathrm{lb} .20 \mathrm{cts}$., lb. 40 cts., 2 lbs. 75 cts.

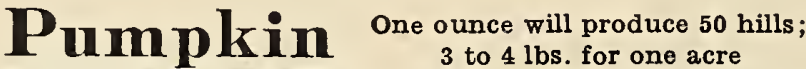

Pumpkins are usually raised in the cornfield. When the corn is about $1 \frac{1}{2}$ feet high, or after it receives its last cultivation, the seed is sown, dropping three seeds in every third hill. The seed may also be sown after May 15, in hills 8 feet apart, placing about 6 seeds in each hill and later thin out to four plants.

King of the Mammoths (Jumbo.) This is indeed a mammoth variety. The Pumpkins Ing are from 2 to 3 feet in diameter, orange-yellow in color, flatshaped, and have thick, bright yellow flesh of excellent quality. Pkt. 5 cts., oz. 20 cts., $\frac{1}{4} \mathrm{lb} .50 \mathrm{cts}$., lb. $\$ 1.50$.

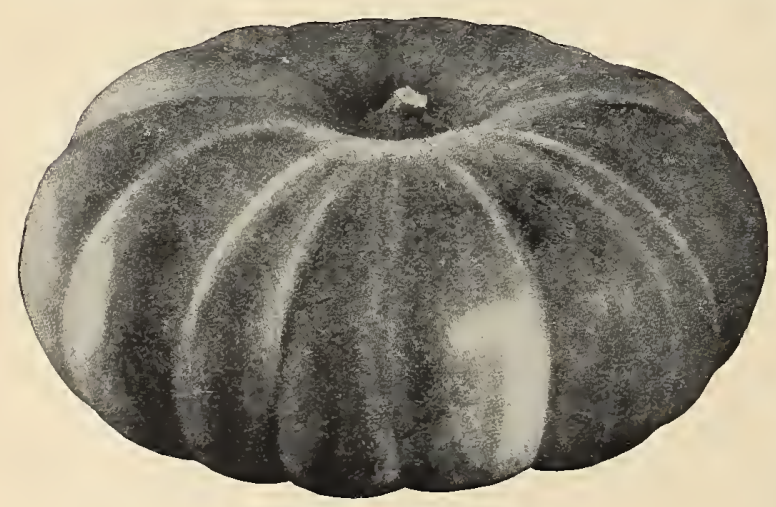

Pumpkin, Large Sweet Cheese
Large Sweet Cheese. Specimens are usually about 2 feet in diameter and one-third as thick. The skin is creamy yellow, while the flesh is unsurpassed for making pies. Our strain of this well-known variety is very fine and highly esteemed for market or home-garden. Pkt. 5 cts., oz. 15 ets., $\frac{1}{4}$ lb. 40 cts., lb. $\$ 1.25$.

Small Sugar. Though small, this is one of the sweetest, and is highly recommended for home use. Round with dark orange-colored skin and thick, solid flesh. Pkt. 5 cts., oz. 15 cts., $\frac{1}{4}$ lb. 40 cts., lb. $\$ 1.25$.

Large Tours. An imported variety noted for its enormous size; specimens often measure 3 feet in diameter and weigh 75 pounds or more. Pkt. 5 cts., oz. 15 cts., $\frac{1}{4}$ lb. 40 cts., lb. $\$ 1.25$. 


\section{RADISH}

One ounce will sow 100 feet of drill

For early use select only forcing varieties and sow in hotbeds or under glass any time from January until March. Begin sowing outdoors as soon as the soil is in working condition, usually early in April, selecting, if possible, a light, sandy loam. Although seed of the monthly Radishes may be sown broadcast from April until September, the summer and winter sorts should be sown in drills 12 to 18 inches apart, but not before May 15, as earlier sowings will most likely run to seed. For winter, sow from July 15 to August 15 in drills 18 inches apart, later thinning out to 6 inches apart.

Crimson Giant. A splendid variety, growing almost double the size of the ordinary round red Radish, wenty-five days. It is solid, crisp, and tender of bright red color, and we recommend it híghly. Pkt. 5 cts., oz. 10 cts., $\frac{1}{4}$ lb. 30 cts., lb. 90 cts.

Earliest Carmine Forcing. An extra-early, olive-shaped, deep red Radish with rather small tops, maturing in about twenty days. Pkt. 5 cts., oz. 10 cts., $\frac{1}{4}$ lb. 30 cts., lb. 90 cts.

Early Round Dark Red. All that its name implies, as well as being of rapid growth and handsome appearance. Fine for forcing. Pkt. 5 cts., oz. 10 cts., $\frac{1}{4}$ lb. 30 cts., lb. 90 cts.

Non Plus Ultra. Especially desirable during the warm summer months, owing to its earliness, short top, and rarely becoming pithy. Pkt. 5 cts., oz. $10 \mathrm{cts}$, $\frac{1}{4} \mathrm{lb} .30 \mathrm{cts}, 1 \mathrm{~b} .90 \mathrm{cts}$.

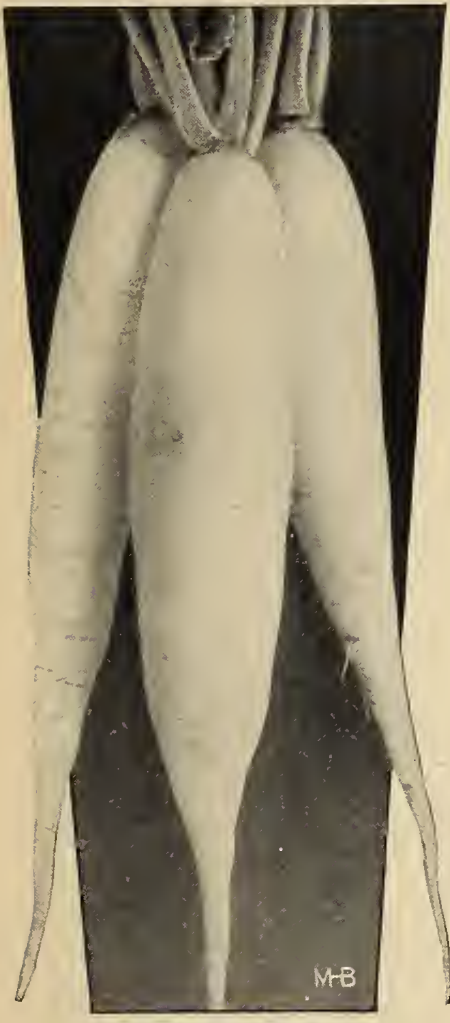

Radish, Icicle

Scarlet Globe Forcing. We offer an exceptionally fine strain of this Radish which is po ular everywhere either for forcing or outside sowing. The roots are slightly tender. It matures early, usually in about twenty-one days, and is a favorite both for the home garden and market. Pkt. 5 cts., oz. 10 cts., ${ }_{4}^{1} 1 \mathrm{lb} .30 \mathrm{cts}$., lb. $90 \mathrm{cts}$.

Early Scarlet Turnip. One of the standard sorts for turnip-shaped, dark red, and of fine qualíty. Has rather large tops. Pkt. 5 cts., oz. $10 \mathrm{cts.,} \frac{1}{4} \mathrm{lb} .30 \mathrm{cts.}, \mathrm{lb} .90 \mathrm{cts}$.

French Breakfast. This well-known Radish is olive-shaped, bright scarlet with the exception of the white tip. Pkt. 5 cts., oz. 10 cts., $\frac{1}{4} l$ b. 30 cts., lb. 90 cts.

Early Scarlet Turnip, White-tipped. An tionally fine strain so largely grown by market-gardeners. Its color is of the deepest scarlet with a prominent white tip; superb flavor. Pkt. 5 cts., oz. 10 cts., $\frac{1}{4} 1$ b. 30 cts., lb. 90 cts.

Early White Turnip. Preferred by many to the red sorts. Flesh clear white, tender, and sweet. Pkt. 5 cts., oz. $10 \mathrm{cts}$., $\frac{1}{4}$ lb. 30 cts., lb. 90 cts.

Icicle One of the earliest and purest of all long white cicle. varieties. For crispness and tenderness it is unsurpassed. Plkt. 5 cts., oz. 10 ets., $\frac{1}{4} 1 \mathrm{~b} .30$ ets., lb. 90 cts.

Long Scarlet Short Top. A long, smooth, tapering Radish somewhat smaller but brighter in color than Chartier. Pkt. 5 cts., oz. 10 cts., $\frac{1}{4}$ lb. 30 cts., lb. 90 cts.

Long White Vienna (Lady Finger). The iskin and flesh are both pure white and of excellent quality. Pkt. 5 cts., oz. 10 cts., $\frac{1}{4} 1$ b. 30 cts., 1b. 90 cts.

Early Golden Yellow Oval. Grows from 3 to 4 inches long, oval-shaped, perfectly solid, and skin bright yellow. Pkt. 5 cts., oz. 10 cts., $\frac{1}{4}$ lb. 30 cts., lb. 90 cts.

Giant White Stuttgart. Splendid for summer use; one of the best for slicing. Pkt. 5 cts., oz. 10 cts., $\frac{1}{4} \mathrm{lb} .30$ cts., lb. 90 cts.

White Summer Turnip. An approved variety for the homegarden. The Radish is round, quite large, and decidedly crísp. Pkt. 5 cts., oz. 10 cts., $\frac{1}{4} 1 \mathrm{lb} .30 \mathrm{cts}$, lb. $90 \mathrm{cts}$

White Strasburg. Handsome, long roots of delicate flavor when small, but remaining in good condition until maturity. Pkt. 5c., oz. 10c., $\frac{1}{4} \mathrm{lb}$. 30c., 1b. 90c.

Brunjes' Half-long Black Winter. Very highly recommended as the best Radish mer. The color of the roots, which grow about 6 inches long and $2 \frac{1}{2}$ inches across the top, is more of a gray than black, while the flesh is pure white. Pkt. 5 cts., oz. 10 cts., $\frac{1}{4} l \mathrm{~b} .30$ cts., lb. 90 cts.

Round Black Spanish. Preferred by some to the longer varicties. Roots round, 3 to 4 inches in diameter, and about the same in length; flesh white. Pkt. 5 cts., oz. 10 cts., 11 lb. 30 cts., lb. 90 cts.

Long Black Spanish. The roots grow about 9 inches long and 2 inches in diameter, and have firm white flesh which is decidedly pungent but well flavored. Grown principally for keeping during the winter: matures latc. Pkt. 5 cts., oz. $10 \mathrm{cts} ., \frac{1}{1} 1 \mathrm{~b} .30 \mathrm{cts} ., \mathrm{lb} .90 \mathrm{cts}$.

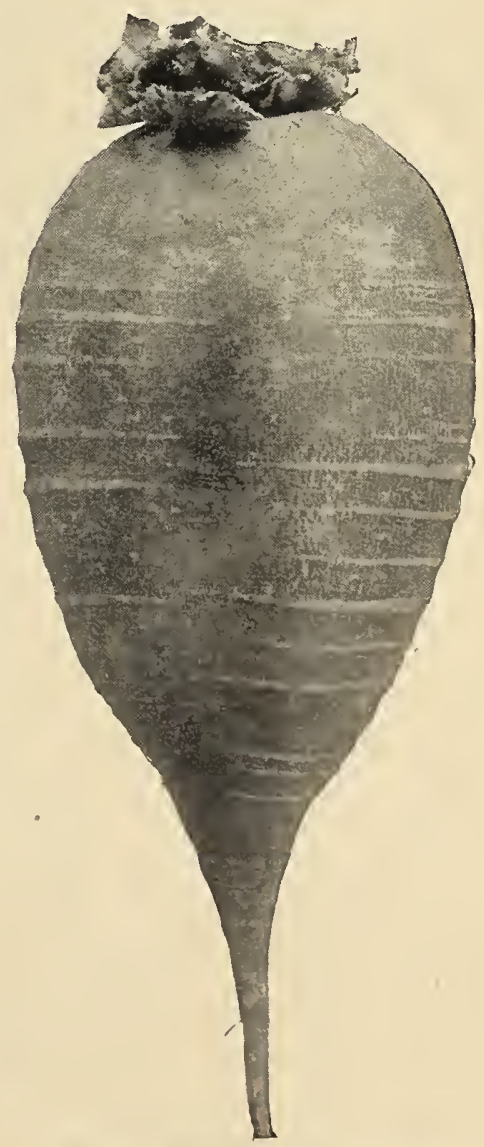

Radish, Half-long Black Winter 

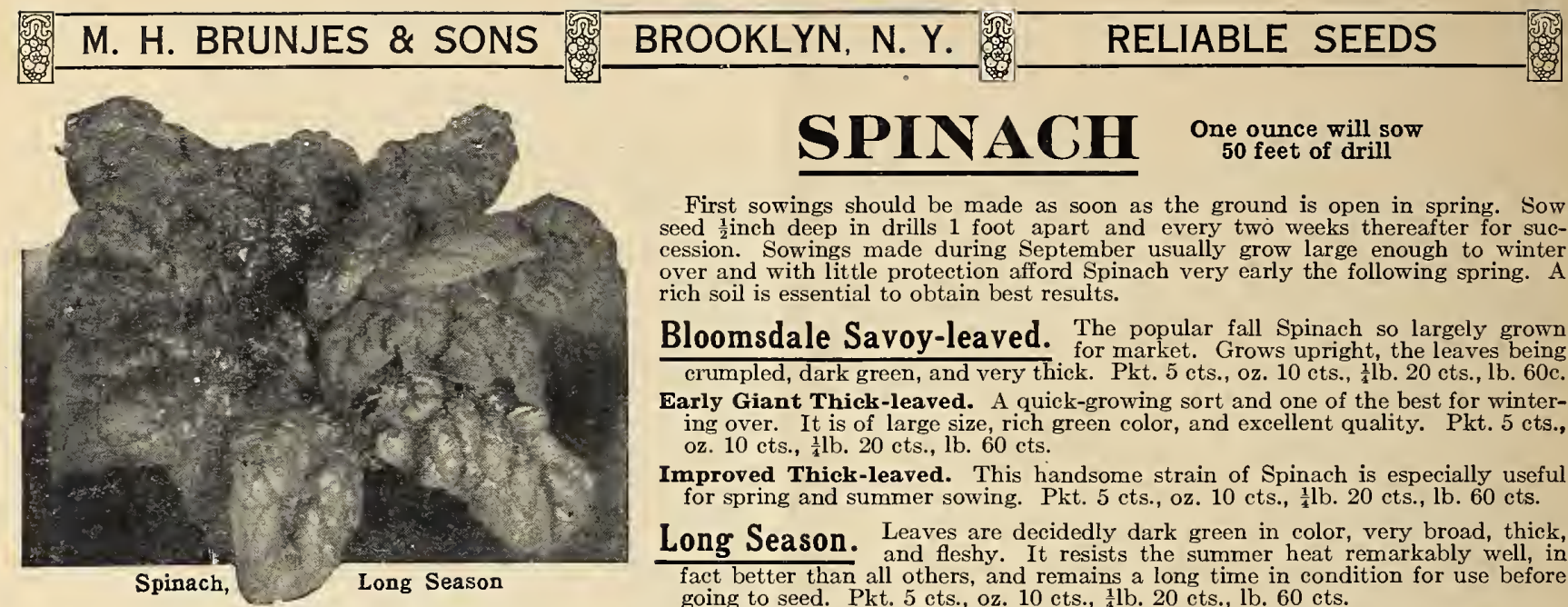

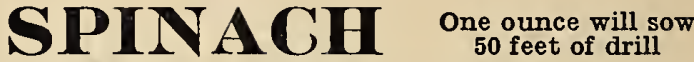

First sowings should be made as soon as the ground is open in spring. Sow seed $\frac{1}{2}$ inch deep in drills 1 foot apart and every two weeks thereafter for succession. Sowings made during September usually grow large enough to winter over and with little protection afford Spinach very early the following spring. A rich soil is essential to obtain best results.

Bloomsdale Savoy-leaved. The popular fall Spinach so largely grown crumpled, dark green, and very thick. Pkt. 5 cts., 0 z. $10 \mathrm{cts}$., $\frac{1}{4} \mathrm{lb}$. $20 \mathrm{cts}$., $1 \mathrm{~b} .60 \mathrm{c}$.

Early Giant Thick-leaved. A quick-growing sort and one of the best for wintering over. It is of large size, rich green color, and excellent quality. Pkt. 5 cts., oz. 10 cts., $\frac{1}{4}$ lb. 20 ets., lb. 60 cts.

Improved Thick-leaved. This handsome strain of Spinach is especially useful for spring and summer sowing. Pkt. 5 cts., oz. 10 cts., $\frac{1}{4} \mathrm{lb} .20$ cts., lb. 60 cts.

Long Season. Leaves are decidedly dark green in color, very broad, thick, fact better than all others, and remains a long time in condition for use before going to seed. Pkt. 5 ets., oz. 10 cts., $\frac{1}{4}$ lb. 20 cts., lb. 60 cts.

Long-standing. Succeds well at almost all seasons and, though rather slow growing, it is a very fine, large, dark green-leaved Spinach. Pkt. 5 cts., oz. $10 \mathrm{cts}$., $\frac{1}{4} \mathrm{lb} .20 \mathrm{cts} ., \mathrm{lb} .60 \mathrm{cts}$.

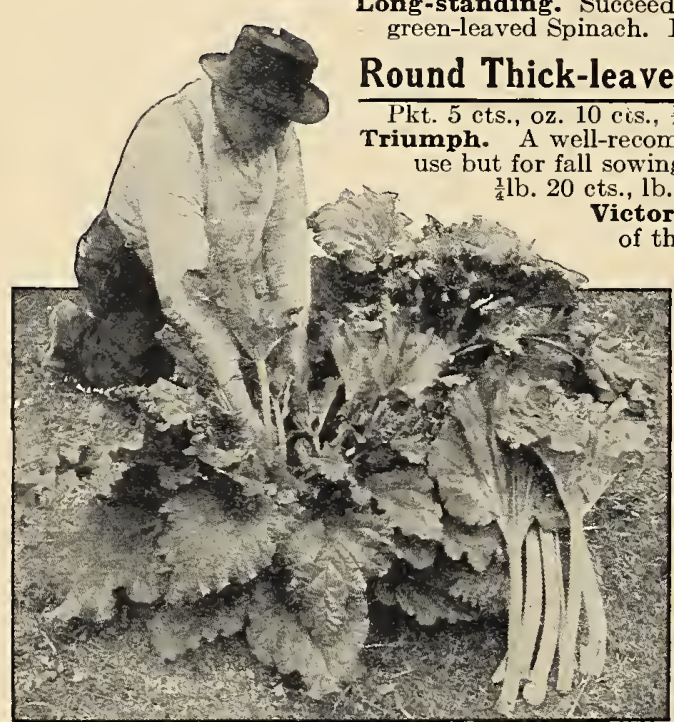

Rhubarb
One of the best and most desirable for the home-garden, either for early or late planting. The round, slightly crumpled leaves are both tender and of good quality.

Pkt. 5 cts., oz. 10 cis., $\frac{1}{4} \mathrm{lb}$. 20 cts., lb. 60 cts.
Triumph. A well-recommended sort of long-standing Spinach, which is not only good for spring and summer use but for fall sowing as well. The leaves are large, thick, and of the choicest quality. Pkt. 5 cts., oz. 10 cts., Victoria. A favorite for early summer. It is one of the darkest in color and, with the exception of the heart, the leaves are comparatively smooth. Pkt. 5c., oz. $10 \mathrm{cts}$., $\frac{1}{4} \mathrm{lb} .20 \mathrm{cts} ., \mathrm{b} .60 \mathrm{cts}$. Viroflay. Matures very early. The leaves are pointed, bright green, and when large should be cut as it soon runs to seed. Pkt. 5 cts., oz. 10 cts., $\frac{1}{3} 1 \mathrm{lb} .20 \mathrm{cts}$., lb. $60 \mathrm{c}$. New Zealand. Distinct from the ordinary Spinach in appearance. The plants are more spreading in growth with small, very dark green leaves, which may be had throughout the hot summer months. Sow seed outdoors during May, dropping about three seeds in hills 2 feet apart each way. Pkt. 5 ets., oz. $10 \mathrm{cts}$., $\frac{1}{4} \mathrm{lb} .30$ sts., lb. 90 cts.

\section{ORDER EARLY}

\section{RHUBARB}

Should be sown during April or May in drills 1 foot apart, covering the seed about $\frac{1}{2}$ inch. Later thin out the seedlings to 4 inches apart and in the fall transplant to permanent beds of well-enriched soil, setting plants not less than 3 feet apart. They will be in condition for use the following year. Pkt. 5 cts., oz. 20 cts., 1 lb. 50 cts.

\section{RHUBARB ROOTS}

Rhubarb may be had one year earlier by planting roots than by sowing the seed. We offer fine, extra-strong roots during April, which is the best month for setting them out. $15 \mathrm{cts}$. each, $\$ 1.50$ per doz. If by parcel post, add postage at zone rate. Weight, $1 \mathrm{lb}$. each.

\section{SALSIFY, or OYSTER PLAN'T}

One ounce will sow 75 feet of drill

This vegetable is best grown in a rich, deep but loose soil. Sow seed about 1 inch deep from April to June 15 in drills 12 inches apart. Later thin out to 4 inches in the row. They are usually ready for use in September but become more delicate in flavor after a light frost.

Mammoth Sandwich Island. The roots are white, extra long, straight, and very tender. Pkt. 5 cts., oz. 25 cts., $\frac{1}{4} \mathrm{lb} .75$ cts., lb. $\$ 2.50$.

\section{SGORZONIRA (Black oyster Plant)}

Should not be sown before May 15, but otherwise is cultivated the same as salsify. The roots are black.

Long Black. Pkt. 5 cts., oz. 20 cts., $\frac{1}{4}$ lb. 60 cts., lb. $\$ 2$.

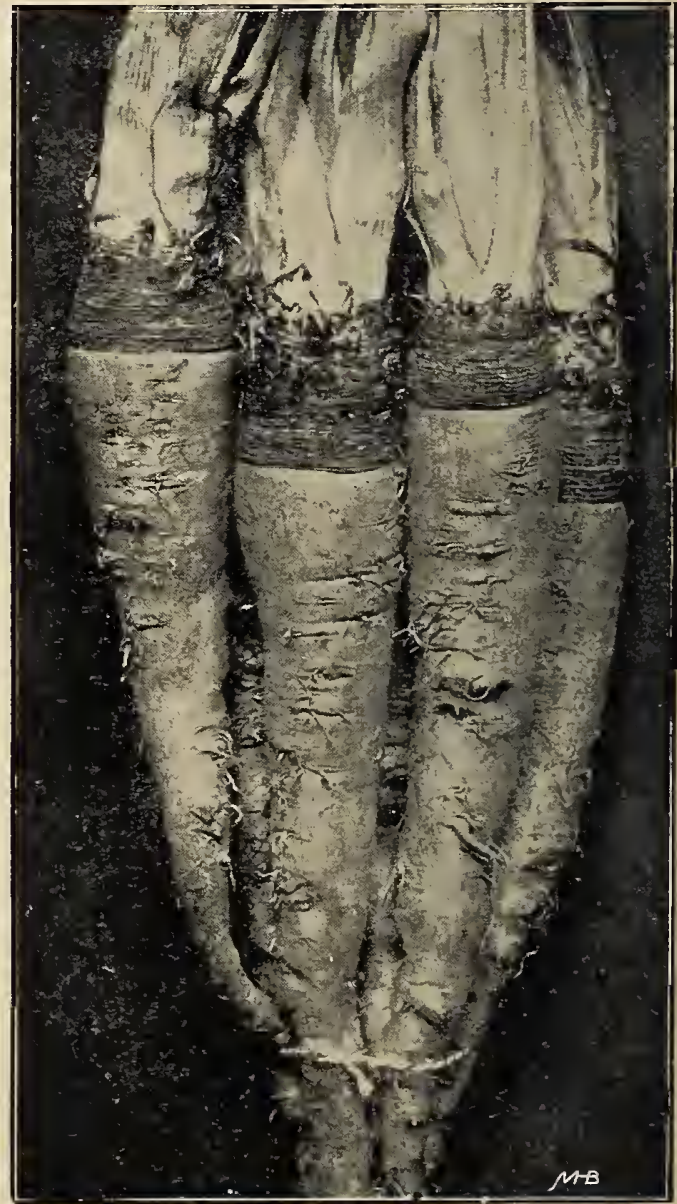

Salsify, Mammoth Sandwich Island 


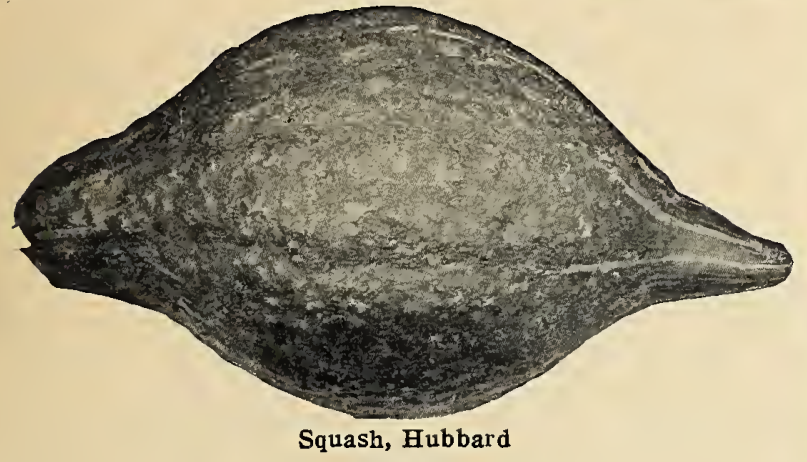

SQUASH

One ounce of Early will plant 50 hills; 1 ounce of Marrow, 25 hills

Not only Squash, but all vine seeds should not be sown until the weather is quite warm. Early or summer varieties are planted during May in hills 4 feet apart; the winter sorts require from 6 to 8 feet and are planted in July. Plant eight or ten seeds 1 inch deep in a hill, but later let only three of the strongest plants remain. Soil should be rich and well manured.

Boston Marrow. This popular, oval-shaped winter Squash is orange, skin yellow. one of the most useful for pies. Flesh rich Cocozella (Italian Vegetable Marrow). An esteemed Italian variety,

15 to 18 inches in length and about 4 inches in diameter; very dark green, striped with white. Pkt. 5 cts., oz. 20 cts., $\frac{1}{4}$ lb. 50 cts., lb. $\$ 1.75$.

Golden Hubbard. In size and shape the same as Hubbard. It is somewhat warted, golden red in color, while the flesh is fine-grained, deep yellow and of extra-rich flavor. Pkt. 5 cts., oz. $20 \mathrm{cts.}, \frac{1}{4} \mathrm{lb} .60 \mathrm{cts}$., lb. $\$ 2$.

Hubbard. A superior dar.

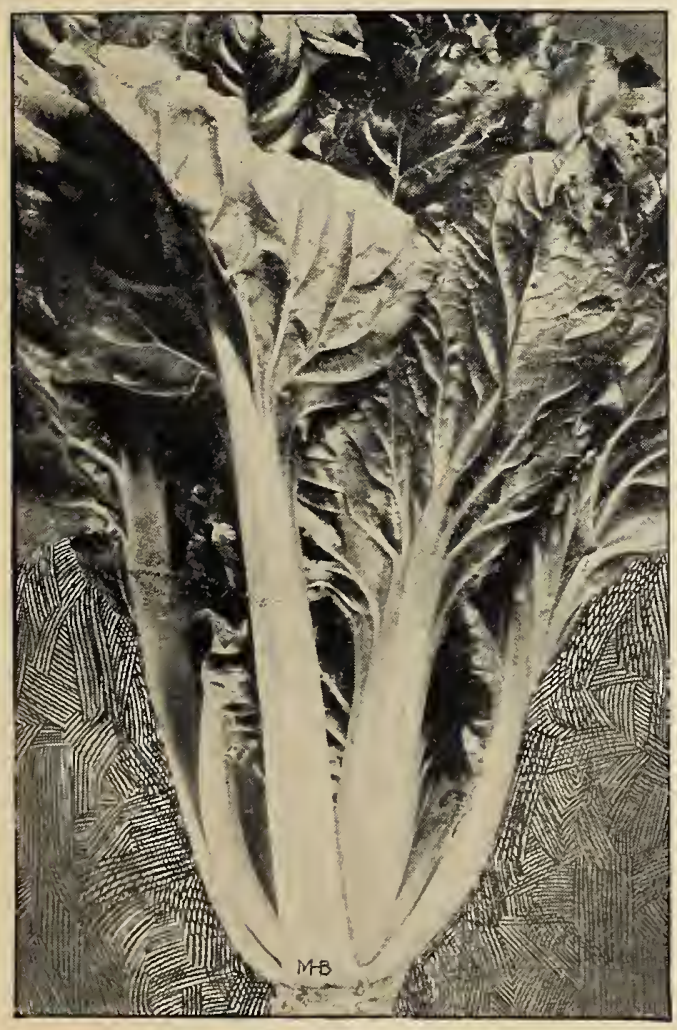

Mammoth Summer Crookneck. The largest and most desirable warted and of a beautiful golden color $\$ 2$.

Mammoth White Bush Scalloped. An early sort of bush habit. The fruits are uniformly large, pure white and of good quality. Pkt. 5 cts., oz. 20 cts., $\frac{1}{4} \mathrm{lb}$. 50 cts., lb. $\$ 1.75$.

\section{SORREL}

\section{One ounce will sow 150 feet of drill}

Seed sown during April in drills 12 inches apart and $\frac{1}{2}$ inch deep will be in condition for cutting about July. For early spring use, a sowing should be made in August. The roots are hardy and if not disturbed will remain for several years. Large-leaved French. Pkt. 5 cts., oz. 25 cts., $\frac{1}{4}$ lb. 75 cts., lb. $\$ 2.50$.

\section{SWISS GHARD, or SPINACH BEET}

One ounce will sow 100 feet of drill

No matter how small the garden, a place should be reserved for this vegetable. The leaves grow quite high and when broken off and cooked like spinach are preferred by many to the latter. By using the outer leaves new ones will always form. Sow seed early in spring in rows 15 inches apart and later thin out to 6 inches in the row. Pkt. 5 cts., oz. 15 cts., $\frac{1}{4} 1$ b. 40 cts., lb. $\$ 1.25$.

Giant Lucullus. This valuable vegctable has replaced spinach in many broad leaves, crumpled may be cooked and served similar to asparagus. Pkt. 5 cts., oz. 15 cts., $\frac{1}{4} \mathrm{lb} .40$ cts., lb. $\$ 1.25$.

\section{TOBACGO}

One ounce will produce plants for one acre

Seed may be sown under glass from February to April or in a sheltered bed outdoors after all danger from frost is over, usually late in May. When the plants are 5 to 6 inches high transplant to beds of good, rich soil, setting plants about 4 fect apart each way and cultivate frequently, as for corn.

Connecticut Seed Leaf. A very popular and one of the hardiest and most largely grown varictics. Pkt. 10 cts., oz. 30 cts., $\frac{1}{4} \mathrm{lb}$. $\$ 1,1 \mathrm{~b}$. $\$ 3.50$.

Imported Havana. Has very thin leaves of fine texture. Pkt. $10 \mathrm{cts}$, oz. $40 \mathrm{cts}$. $\frac{1}{1}$ lb. $\$ 1.25$, lb. $\$ 4.50$. 


\section{TOMATO}

For early Tomatoes start plants in hotbeds during March, sowing the seed $\frac{1}{4}$ inch deep in drills 6 inches apart. They should be replanted at least once in the frames before the final planting outdoors in May, after all danger of frost is past. It is unwise to set plants closer than 3 to 4 feet apart each way, as the viues grow vigorously and soon cover the entire space. In gardens where space is limited and only a few plants grown, we recommend the use of tomato supports.

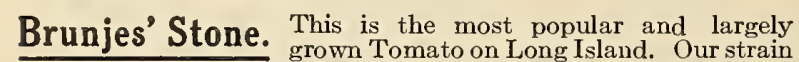
of this variety is exceptionally fine and we can recommend it highly to the most critical grower. The fruit is extra large, very smooth, exceedingly heavy and of a handsome, brilliant scarlet color, while the shape is round and slightly flattened. For ketehup-making or canning it is unsurpassed. Pkt. 5 cts., oz. 35 cts., $\frac{1}{4} \mathrm{lb} . \$ 1.10,1 \mathrm{~b} . \$ 3.75$.

Acme. Matures early, is purple-red in color, smooth and very productive. Pkt. 5 cts., oz. 35 cts., $\frac{1}{4} \mathrm{lb}$. $\$ 1.10,1 \mathrm{~b}$. $\$ 3.75$.

Bonny Best. A beautiful, bright scarlet Tomato for the homegarden, maturing about the same time as Early Jewel. The vines are of good sturdy growth and heavy yielders of round, deep fruit, very solid and unsurpassed in quality. Pkt. 5 cts., oz. 40 cts., $\frac{1}{4} \mathrm{lb}$. $\$ 1.25, \mathrm{lb}$. $\$ 4$.

Dwarf Stone. In growth it is somewhat like the preceding variety. The Tomatoes are considerably larger, while the flesh is firm and heavy which makes it a first-class sort for the garden. Pkt. 5 cts., oz. 40 cts., $\frac{1}{4} \mathrm{lb}$. $\$ 1.40,1 \mathrm{~b}$. $\$ 5$.

Brunjes' Earliana. An exceedingly early Tomato of deep red color. The and produced in large clusters on short, compact bushes. Every grower of Tomatoes should include a packet of this sterling variety in their order. Pkt. 5 cts., oz. 40 cts., $\frac{1}{4}$ lb. $\$ 1.25,1$ lb. $\$ 4$.

Early Jewel. This variety is somewhat larger than Earliana but matures some bright scarlet color. One of the best for the home garden. Pkt. 5 cts., oz. 40 cts., $\frac{1}{4} \mathrm{lb}$. $\$ 1.25,1 \mathrm{~b}$. $\$ 4$.

John Baer. Our customers will find John Baer one of the best large, early cropper, and continues to bear longer than most early varieties. The fruit is almost round, bright scarlet, very solid, and has small seed-cavity. Pkt. 10 cts., oz. 50 cts., $\frac{1}{4}$ lb. $\$ 1.60, \mathrm{lb}$. $\$ 6$.

Golden Queen. Rich golden yellow, equal to the red sorts, both in size and flavor. Pkt. 5 cts., oz. 35 cts., $\frac{1}{4} \mathrm{lb}$. $\$ 1.10$, lb. $\$ 3.75$.

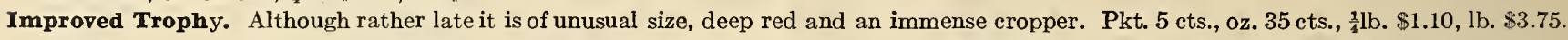

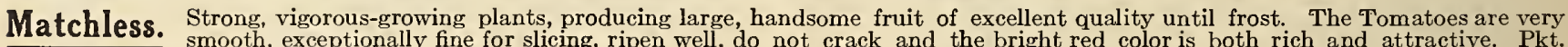
$\frac{1 \text { atchless. }}{5 \text { cts., oz. } 35 \text { cts., } \frac{1}{4} \mathrm{lb} . \$ 1.10,1 \mathrm{~b} . \$ 3.75 \text {. }}$

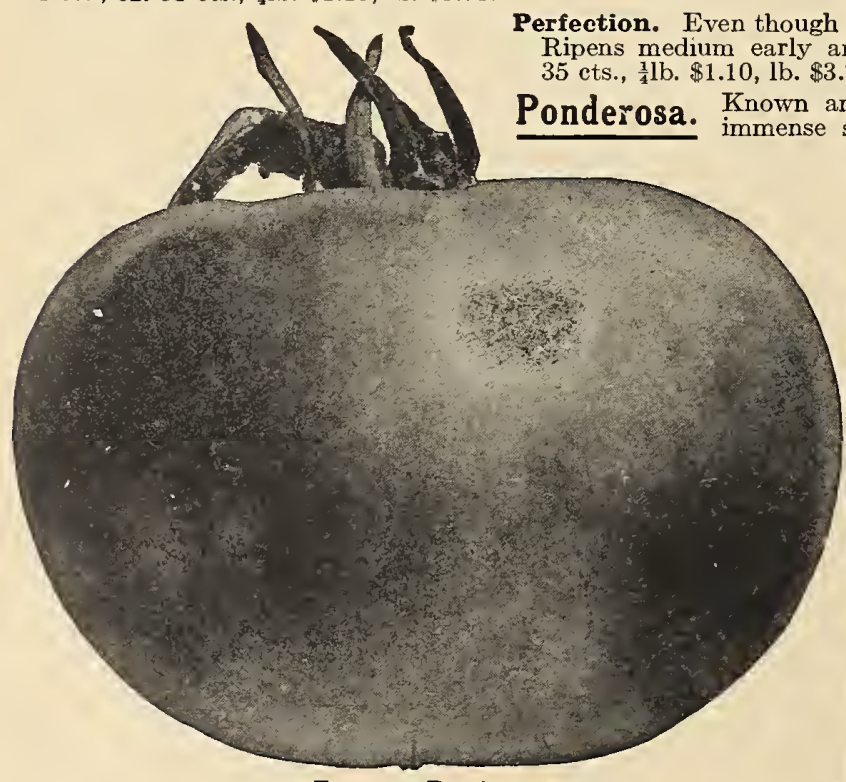

Tomato, Ponderosa 35 cts., $\frac{1}{4} \mathrm{lb} . \$ 1.10, \mathrm{lb} . \$ 3.75$.

Perfection. Even though one of the oldest, it is still preferred by many to the later introductions. Ripens medium early and is esteemed both for market and home gardens. Pkt. 5 cts., oz.

onderosa. Known and planted in almost all parts of the country. It is noted for its immense size, being perhaps the largest of all Tomatoes, and often specimens have been known to weigh one and sometimes two pounds each. The fruit is deep purplish pink, very solid and meaty, of good quality and, unlike most varieties, has but very few seeds. Whether you grow other varieties or not, you should try Ponderosa and with little extra care you will be astonished at the size of the Tomatoes. Pkt. 10 cts., oz. 50 cts., $\frac{1}{4} \mathrm{lb} . \$ 1.75, \mathrm{lb}$. $\$ 6.50$.

Red Rock. We consider this one of the best all-round Tomatoes for general planting. The fruit is extra large, smooth, of a rich red color, very solid, and ripens evenly without cracking. Pkt. $5 \mathrm{cts.}, \mathrm{oz} .35 \mathrm{cts}$., $\frac{1}{4}$ lb. $\$ 1.10$, lb. $\$ 3.75$.

Paragon. A desirable, smooth, very solid Tomato of deepest red; useful for the table and preserving. Pkt. 5 cts., oz. 35 cts., $1 / 4 \mathrm{lb}$. $\$ 1.10,1 \mathrm{~b} . \$ 3.75$.

Red Cherry, Yellow Plum. Fine for preserving. Each, pkt. 5 cts. oz. $40 \mathrm{cts}$.

TOMATO PLANTS. See page 28

\section{PEAS, BEANS, and GORN}

Remember Peas, Beans, and Corn are now sold by weight, instead of measure. One pound of Beans is about a pint, and one pound of Peas and Corn a little more than a pint. 


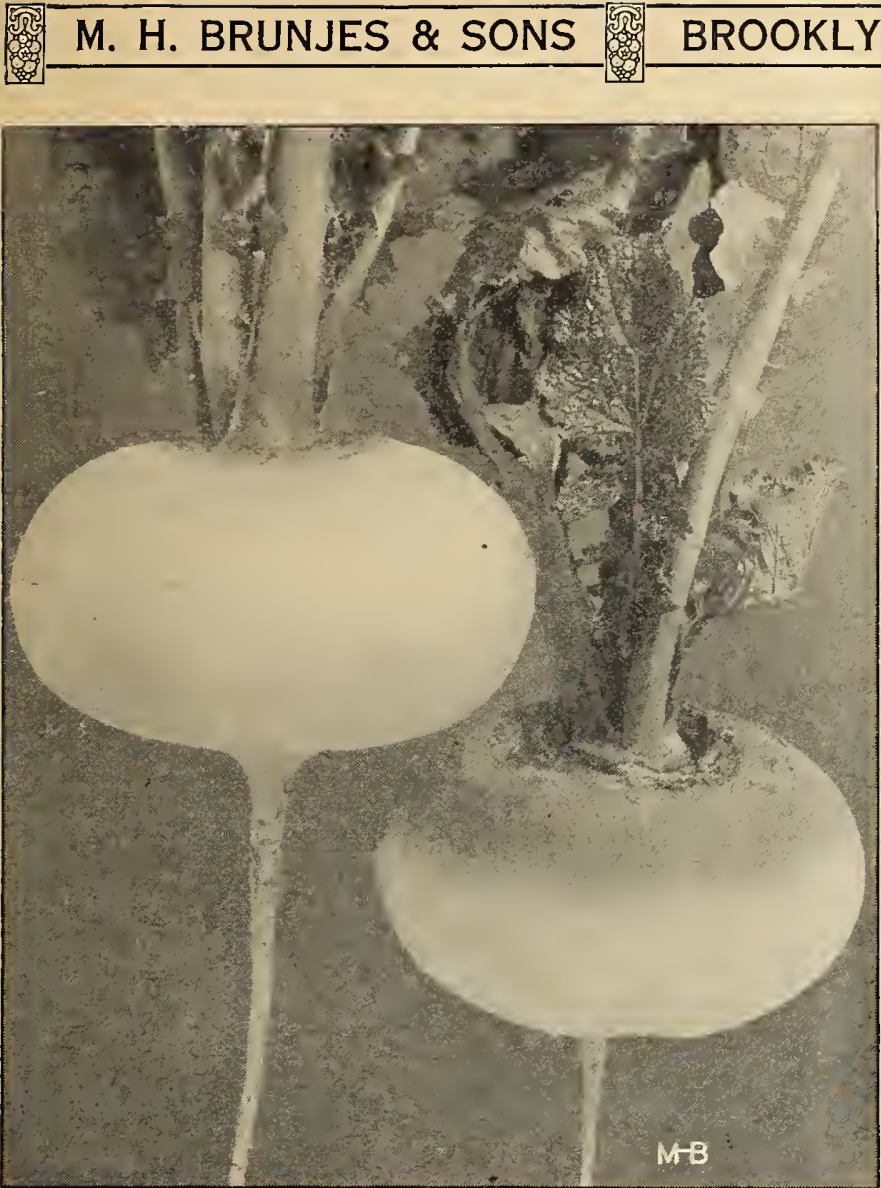

Turnip, Extra-Early White Milan Turnip, Purple-Top White Milan

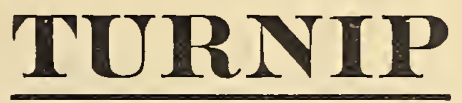

One ounce will sow 100 feet of drill; two pounds will sow one acre

For early use sow in hotbed during March, selecting either of the Milan varieties. Sowings may be made outdoors in drills 12 inches apart as soon as the ground can be worked in spring, and later thin out to 5 inches in the row. For succession sow at intervals of a fortnight until the last week of July, from which time until the end of August, sowings should be made for the late crops. Early Snowball. A first-class table variety with small, round, ball-shaped roots of the purest white; very tender. Pkt. 5 cts., oz. 10 cts., ${ }_{4}^{1} \mathrm{lb} .25$ cts., lb. 75 cts.

Extra-Early White Milan. Exceptionally fine for early outdoors. The bulb is smooth, flat and of medium size. Pkt. 5 cts., oz. 20 cts., $\frac{1}{4}$ lb. 50 cts., lb. $\$ 1.50$.

Purple-Top White Milan. Almost identical in size and shape with the preceding but with purple crown. The flesh is white, swect and fine flavored. Pkt. 5c., oz. $20 \mathrm{c}$., $\frac{1}{4} 1 \mathrm{lb} .50 \mathrm{cts}, \mathrm{lb} . \$ 1.50$.

Purple-Top Strap-leaf. A flat, quick-growing variety, popular either for spring or fall. Pkt. 5 cts., oz. 10 cts., $\frac{1}{4} \mathrm{lb} .25$ ets., lb. 75 cts.

Purple-Top White Globe. One of the best and most pruThe roots are globe-shaped, extra large, and very solid; flesh fine grained and purest white. For winter use sowings should be made about August 20. Pkt. 5 cts., oz. 10 cts., $\frac{1}{4} l$ b. 25 cts., lb. 75 cts.

Seven Top. The roots are of no particular use although the leaves, for which it is chiefly grown, furnish greens throughout the winter in southern states. Pkt. 5 ets., oz. 10 cts., $\frac{1}{1}$ lb. 25 cts., lb. 75 cts.

Yellow Stone. Keeps well during winter. Color of skin and flesh is bright yellow, the latter being firm, sweet, and tender. Pkt. 5 cts., oz. 10 cts., $\frac{1}{4}$ lb. 30 cts., lb. 90 cts.

\section{RUTABAGA (Russian or Swede Turnip)}

One ounce will sow 100 feet of drill; two pounds for one acre

Sow seed from middle of June to July 15, in drills $1 \frac{x}{2}$ to 2 feet apart, later thinning the plants to 8 inches in the row. They should be pulled before severe weather and, after removing the tops, stored in the cellar or pit outdoors.

Long Island Improved. We offer an exceptionally fine strain of this popular winter Turnip. Large, well-shaped roots, short neck, and of a bright yellow color with purple top. The finest of all for table use; flesh sweet, tender, and solid. A good keeper and largely grown for stock-feeding. Pkt. 5 cts., $0 z .10$ cts., $\frac{1}{4} l$ b. 25 cts., lb. 80 cts.

\section{Herbs, Sweet, Pot and Medicinal}

Do not fail to devote a small space in your garden to the cultivation of herbs. Sow during May or June in drills 1 foot apart, covering the seed very lightly and later thin out or transplant to 6 inches in the row. Before in full blossom the plants should be cut, tied in small bunches and hung up in the shade to dry, after which they are placed in boxes or bottles for winter use

Anise (Pimpinella Anisum). Biennial..

Basil, Sweet (Ocimum Basiticum). Annual.

Caraway (Carum Carui). Perennial.

Coriander (Coriandrum sativum). Annual.

Pkt. Oz

Horehound (Marubium vulgare). Perenni....

Hyssop (Hyssopus officinalis), Perennial

Lavender (Lavandula spica). Perennial.....

Marjoram, Sweet (Origanum Majorana). Annual

Rosemary (Rosemarinus officinalis). Perennial ..

Rue (Ruta graveolens). Perennial...

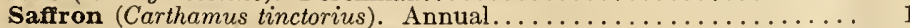

Sage (Salvia officinalis). Annual...

Summer Savory (Satureia hortensis). Ännual.

Wormwood $(t$

SEEDS BY PARCEL POST.-Orders for packets, ounces, and quarter-pounds will be sent by parcel post, postage free, at prices given. For larger quantities, add postage at zone rates. See inside of front cover page before making out your order.

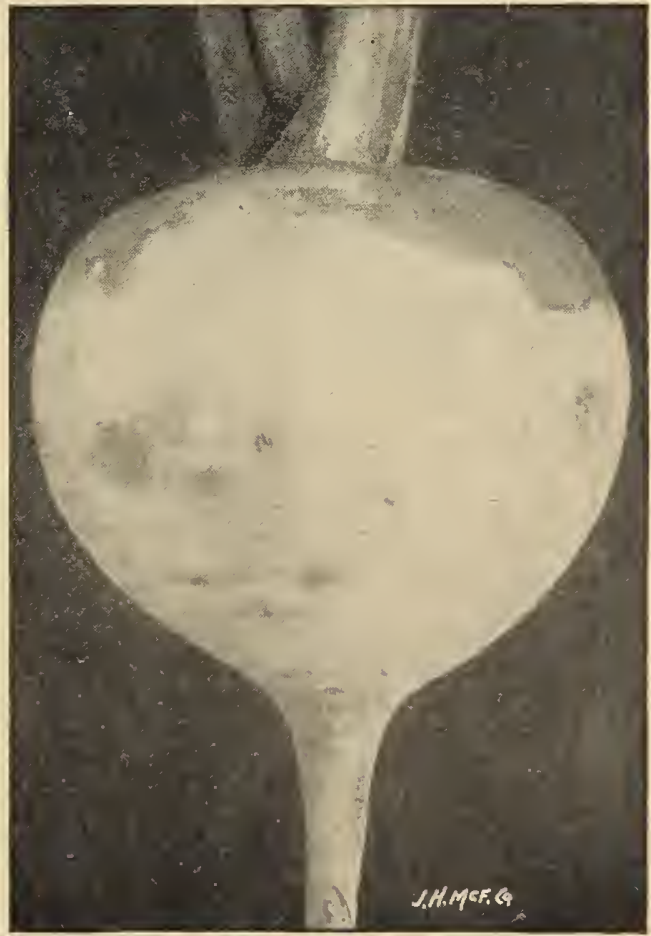

Turnip, Purple-Top White Globe 


\section{VEGETABLE PLANTS}

If wanted by parcel post, add postage at zone rates. One dozen plants will average one pound. Our plants are grown in flats containing 100 each. Less than 100 plants of one variety will be charged at dozen rates.

CABBAGE. Ready May 1. All Head Early, American Drumhead Savoy, Mammoth Rock Red. 25 cts. per doz., $\$ 1.75$ per 100.

CAULIFLOWER. Ready. May 1. Early Snowball. 25 cts. per doz., $\$ 1.75$ per 100 .

CELERY. Ready May 1. Soup or Cutting. 20 cts. per doz., $\$ 1.40$ per 100 .

CELERY. Golden Self-Blanching. Strong, transplanted plants. Ready July 1. 20 cts. per doz., \$1.40 per 100.

CELERIAC. Ready May 1. Large Smooth Prague. 20 cts. per doz., $\$ 1.40$ per 100 .

EGGPLANTS, Pot-Grown. Ready May 15. New York Improved Purple. 50 cts. per doz., $\$ 3.50$ per 100 .
KOHLRABI. Ready May 1. Early White Vienna. 20 cts. per doz., $\$ 1.40$ per 100 .

LETTUCE. Ready May 1. Big Boston. 20 cts. per doz., $\$ 1.40$ per 100.

PEPPER PLANTS. Ready May 15. Large Bell, or Bull Nose. 25 cts. per doz., $\$ 1.75$ per 100 .

RHUBARB ROOTS. $15 \mathrm{cts}$. each, $\$ 1.50$ per doz. If by parcel post, add postage at zone rate. Weight, $1 \mathrm{lb}$. each.

\section{TOMATO PLANTS Ready May 1}

Ponderosa. 30 cts. per doz., $\$ 2$ per 100 .

Early Jewel, Stone. 25 ets. per doz., \$1.75 per 100.

\section{FARM SEEDS}

Prices are subject to market changes

CANADA FIELD PEAS, White. Pk. $\$ 1.75$, bus. (60 lbs.) $\$ 6$.

SPRING VETCHES. Grown for soiling, or sown with oats for feeding green. Two bushels will sow one acre. Bus. (60 lbs.) $\$ 6.50$.

BUCKWHEAT, Japanese. Matures early, is a heavy yielder and makes the best flour. Sow one-half bushel, broadcast, to the acre, about the middle of June. Bus. (48 lbs.). Market price.

DWARF ESSEX RAPE. Sown from April to July, it forms an excellent pasturage for sheep and besides is one of the best green feeds for other cattle. Sow $10 \mathrm{lbs}$. to the acre broadcast, and $5 \mathrm{lbs}$. in drills about 15 inches apart. Lb. 25 cts., bus. (50 lbs.) $\$ 9$.

MILLET, German, or Golden (Panicum miliaceum aureum). Grows from 3 to 5 feet high, and on good soil produces a large crop of hay. Sow 1 bushel to the acre. Bus. (50 lbs.) $\$ 6$.

MAMMOTH RUSSIAN SUNFLOWER. The tall-growing plants form immense-sized heads, containing a large quantity of striped seed which is fine for feeding to fowls. Four pounds will sow one acre. Lb. 18 cts., 100 lbs. $\$ 15$.

\section{FIELD GORN 14 pounds will}

If wanted by parcel post, add postage at zone rates

Improved Leaming. (Dent.) Matures quite early, adapted to almost all soils and is largely planted in both the northern and southern states. The long, tapering ears have golden yellow grains of medium size and, on an average, two are produced on each stalk. Lb. 15 cts., 7 lbs. (1/2pk.) 85 cts., 14 lbs. (pk.) $\$ 1.50,56$ lbs. (bus.) $\$ 5$.

Queen of the Prairie. (Pride of the North.) One of the earliest yellow dent varietics maturing in about 85 days. The ears are of medium size, with deep yellow kernels; cob bright red. Lb. 15 cts., 7 lbs. (1/2pk.) 85 cts., 14 lbs. (pk.) $\$ 1.50,56$ lbs. (bus.) $\$ 5$.

Silver King. Ears about 9 inches long, 12-rowed and well filled with deep grained kernels. The earliest white dent variety. Lb. 15 cts. 7 lbs. ( $1 / 2 \mathrm{pk}$.) 85 cts., 14 lbs. (pk.) $\$ 1.50,56$ lbs. (bus.) $\$ 5$.

Longfellow. (Flint.) Particularly adapted for growing in the north. Ears 12 to 15 inches long and $11 / 2$ inches in diametcr; 8-rowed, large broad grains and small cob. Lb. 15 cts., 7 lbs. (1/2pk.) 85 cts., 14 lbs. (pk.) $\$ 1.50,56$ lbs. (bus.) $\$ 5$.

WHITE SANFORD. (Flint.) Medium-sized ear, 8-rowed, kernels large, broad and of a silvery white color; very productive. Lb. 15 cts., 7 lbs. (1/2pk.) 85 cts., 14 lbs. (pk.) $\$ 1.50,56$ lbs. (bus.) $\$ 5$.

\section{GRASS AND GLOVER SEEDS}

Prices subject to changes. Special quotations for large quantities. If wanted by parcel post, add postage at zone rates

Crested Dog's-tail (Cynosurus cristatus). For lawns and pastures. 1 to $1 \frac{1}{2}$ feet. $30 \mathrm{lbs}$. to the bushel. Lb. 65 cts., bus. $\$ 18$.

Kentucky Blue Grass (Poa pratensis). Fancy cleaned. The standard grass for lawns and pastures. Largely grown and very nutritious. Sow 3 bushels to the acre. 21 lbs. to the bushel. Lb. 50 cts., 10 lbs. $\$ 4.50,100$ lbs. $\$ 36$.

Orchard Grass (Dactylis glomerata). It is extremely early and desirable to mix with other grasses for pasture or hay. Particularly adapted to shady places. $14 \mathrm{lbs}$. to the bushel. Lb. 40 cts., bus. $\$ 5$.
Red or Creeping Fescue (Festuca rubra). Valuable for lawns, especially on sandy soil or near the seashore. $14 \mathrm{lbs}$. to the bushel. Lb. 50 cts., bus. $\$ 6.50$.

Red Top (Agrostis vulgaris). Fancy. A perennial grass generally useful. Requires no particular soil and is suitable for lawns and pastures. $32 \mathrm{lbs}$. to the bushel. Lb. 35 cts., bus. $\$ 9.50,100 \mathrm{lbs}$., $\$ 24$.

Timothy, or Herd Grass (Phleum pratense). Most largely grown and producing the finest crop of hay. Also sown with clover. Sow $\frac{1}{2}$ bushel to the acre. 45 lbs. to the bushel. Lb. 25 cts., 10 lbs. $\$ 2$, bus. $\$ 7,100$ lbs. $\$ 15$

\section{CLOVERS}

If wanted by parcel post, add postage at zone rates

Alfalfa, or Lucerne. Prized as a forage plant and yields an immense crop of hay on loose, rich soil. Sow 20 to 30 lbs. to the acre. Lb. 40 cts., 10 lbs. $\$ 3.50,100$ lbs. $\$ 30$.

Alsike (Trifolium hybridum). Perennial. Sow with other grasses, when it is excellent for pasturage or hay. Lb. 50 cts., 16 lbs. $\$ 4.50,100$ lbs. $\$ 40$.

Crimson (Trifolium incarnatum). An annual Clover, largely used for green manure. Sow in August or September. Lb. 25 cts., 10 lbs. $\$ 2.25$, 100 lbs. $\$ 18$.

Medium Red (Trifolium pratense). When used with Timothy makes excellent hay; also used for soiling. Lb. 45 cts., $10 \mathrm{lbs}$. $\$ 4,100 \mathrm{lbs}$. $\$ 35$. White (Trifolium repens). The best variety for lawns and also included in permanent mixtures. Lb. 90 cts., $10 \mathrm{lbs}$. $\$ 8.50,100 \mathrm{lbs}$. $\$ 80$.

\section{BIRD SEED}

If wanted by parcel post, add postage at zone rates

Canary

Rape.

Hemp

Mixed Canary Seed
$\$ 0$

Lettuce Seed

Lb.

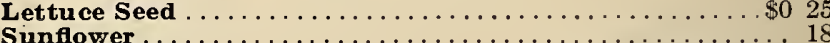

Bird Gravel

Cuttlefsh Bone... package, 5 cts.

. Dozen, 40 cts. 


\begin{tabular}{|c|c|c|}
\hline M. H. BRUNJES \& SONS & BROOKLYN, N. Y. 樆 & RELIABLE SEEDS \\
\hline
\end{tabular}

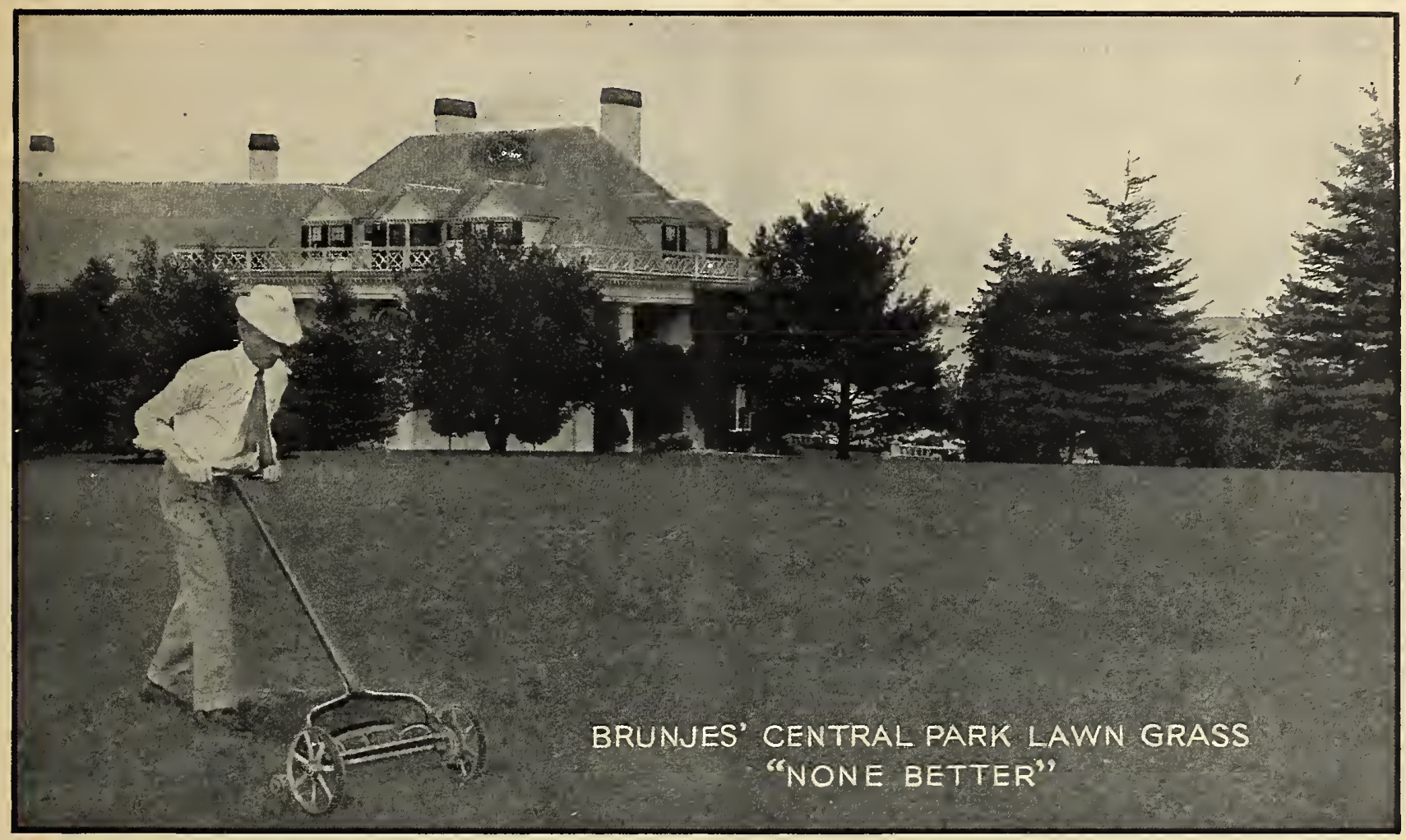

\section{H. BRUNJES \& SONS}

\section{Choice Central Park Lawn Grass}

\section{The Finest Lawns Are Made from This Mixture}

\section{Weight, 20 lbs. per bushel}

A beautiful lawn always adds to the attractiveness of the home, and we can truthfully say that many of the finest lawns have been produced from our Choice Central Park Lawn Grass Mixture. It weighs 20 pounds to the bushel, and is composed of the finest dwarf evergreen grasses, which mature during different months, thus insuring a thick, rich, velvety green lawn almost through the year. Although the greater number of lawns have been made by sowing the seed in spring, usually from the end of March until July, equally good results can be obtained from fall-sown seed. In the early spring a dressing of our Lawn Invigorator, Bone Meal, or Sheep Manure is very beneficial. In making a lawn it should always be remembered to sow the seed thickly. One quart will sow $15 \times 20$ feet ( 300 square feet), 1 bushel $100 \times 108$ feet (10,800 square feet), 4 bushels one acre $(43,560$ square feet).

Qt. 30 cts., 2 qts. 55 cts., 4 qts. $\$ 1$, pk. $\$ 1.75$, bus. (20 lbs.) $\$ 6$. If wanted by parcel post, add postage at zone rates.

One quart weighs $3 / 4$ lb.

Full directions for making a lawn printed on each box.

\section{H. BRUNJES \& SONS' Shady Nook Lawn Grass}

In shady places, espccially under trees, may often be secn bare spots which spoil the appearancc of the balance of the lawn. For such places we can recommend this mixture, as it contains only those grasses suited for growing in shady places. Use the same quantity of seed as given above.

Qt. 30 cts., 2 qts. 60 cts., 4 qts. $\$ 1.10$, pk. $\$ 1.90$, bus. (20 lbs.) $\$ 7$. If wanted by parcel post, add postage at zone rates. One quart weighs $3 / 41 \mathrm{lb}$.

\section{LAWN REQUISITES}

To give the lawn the proper care, it is necessary to have good tools. We carry a very complctc stock of lawn requisites, such as Lawn Mowers, Lawn Rollers, Sprinklers, Rubbcr Hose, cte, at very moderate prices. It would give us plcasure to serve our customers with requircments needed in this line. 


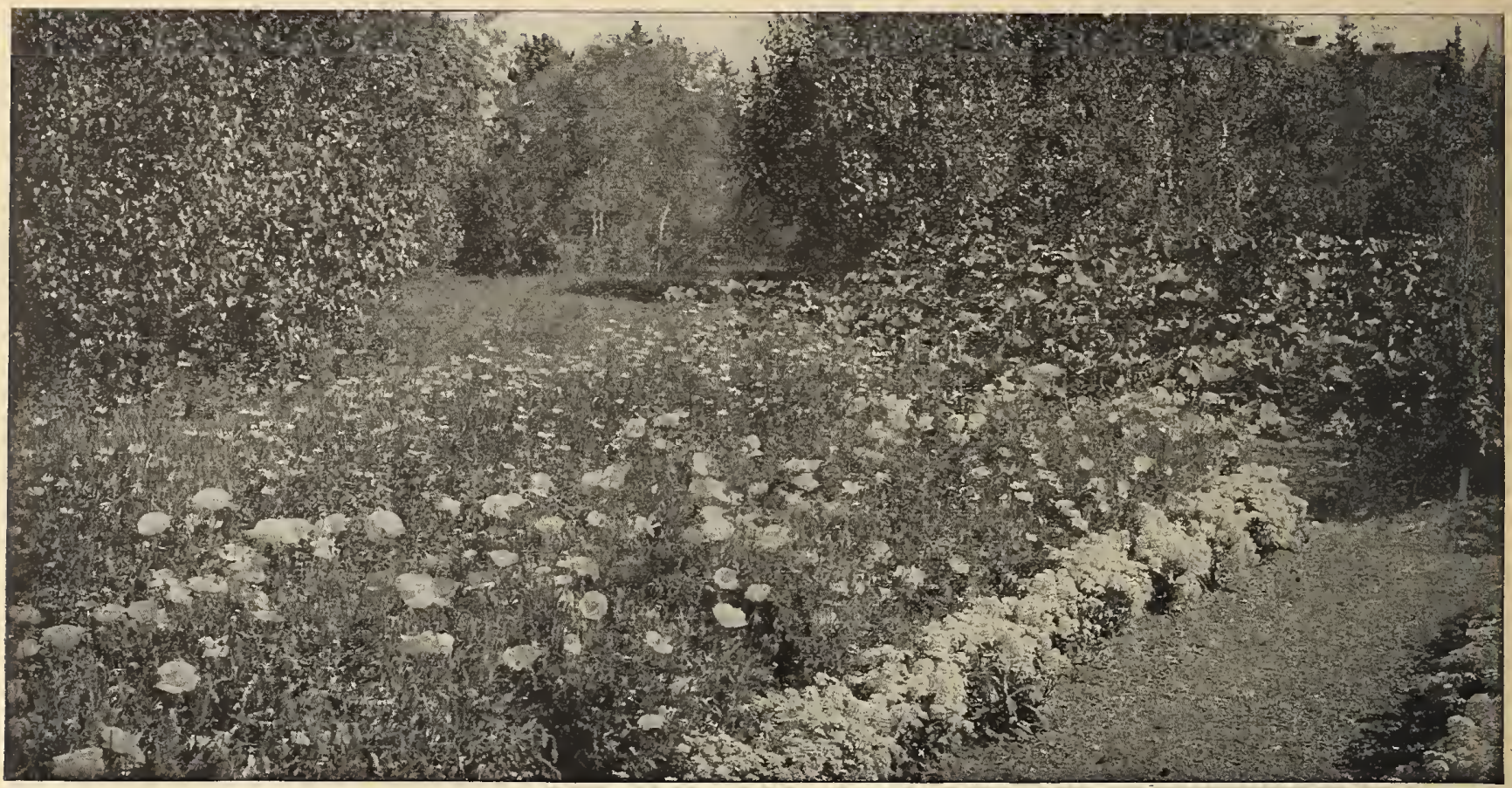

\section{H. BRUNJES \& SONS \\ Flower Seeds}

The following Abbreviations are used throughout the Flower Seed portion of our Catalogue

H. A.

\begin{tabular}{l|l} 
: Hardy Annuals. & H. P.. \\
\hdashline Tende-Hardy Annuals. & H. H. P. \\
H. B.
\end{tabular}

Hardy Perennials.

Half-Hardy Perennials. H. C.

Half-Hardy Biennials.

T. A. A.

Full directions for sowing FLOWER SEEDS printed on each packet

WE PREPAY POSTAGE ON ALL FLOWER SEEDS IN PACKETS AND OUNCES

ABRONIA Umbellata (Sand Verbena). A pretty trailing annual with rosy lilac sweet-scented, verbena-like flowers, suit- Pkt. ed for hanging-baskets and vases. Prefers a sandy soil. $\frac{1}{2} \mathrm{ft} . . \$ 005$

ABUTILON. Bell-shaped perennial shrubs, of easy cultivation and valuable as a house-plant in winter and for the garden in summer. $3 \mathrm{ft}$. G. S. Finest Mixed Hybrids ... 10 ACHILLEA, The Pearl. From June to October this hardy perennial, growing about $1 \frac{1}{2}$ feet high, is a mass of pure white double flowers.

ACONITUM Napelius. Long spikes of blue hood-shaped flowers. Tall growing plants suitable for hardy borders and thriving best in shady locations. $4 \mathrm{ft}$. H. P.
ACROCLINIUM. These splendid Everlastings are pretty as garden annuals or may be gathered when the buds first open and preserved for winter. $1 \mathrm{ft}$.

Double Mixed. Rose and White........ 15 cts 05

ADLUMIA cirrhosa (Mountain Fringe). A hardy biennial climber with feather-like foliage and innumerable small, tube-shaped rose flowers. Height, $15 \mathrm{ft} . \ldots \ldots \ldots \ldots \ldots$

ADONIS zstivalis (Flos Adonis). The single, scarlet flowers are bright and showy, contrasting well with the finecut, dark green foliage. $1 \mathrm{ft}$. H. A............ $25 \mathrm{cts} .$.

Vernalis. A perennial blooming in May; large, bright yellow flowers. $1 \mathrm{ft} . . . \ldots \ldots \ldots \ldots \ldots \ldots \ldots \ldots$. $\frac{1}{4} \mathrm{Oz} .20 \mathrm{cts} .$.

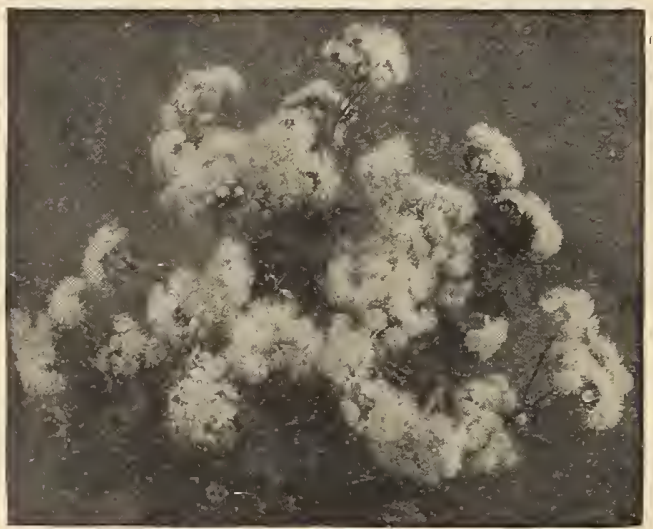

Ageratum, Blue Perfection

\section{AGERATUM}

This everblooming annual is of the easiest culture and one of the leading blueflowered plants, whether for bordering or bedding. Its rich blue flowers are formed in clusters and at times fairly cover the entire plant. Pkt. $1 / 40 z$

Blue Perfection. Flowers of the largest size and deepest blue. 8 inches $\$ 0 \quad 05 \$ 025$ Blue Star. A handsome miniature variety growing only 5 inches high.

Plants are one mass of bright blue flowers.................... 10

Imperial Dwarf Blue. A splendid free-flowering sort. Fine for bedding.

A very popular blue variety. 8 inches....................... 05

Imperial Dwarf White. Similar to the above but having flowers of the purest white. 8 inches........................................ 05 Little Dorrit. Dwarf bushy plants, about 6 inches high, with beautiful azure-blue flowers. Fine for pot culture .................. 05

AGROSTEMMAa Coeli-rosa (Rose of Heaven). A free-blooming annual, not more than $1 \frac{1}{2}$ feet high, having bright rose-colored flowers which are

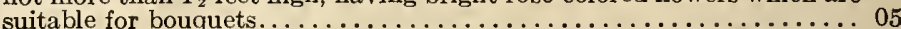

Coronaria. (Rosc Campion). Effective when grown in masses and if sown early, blooms the first season. Single, dark red flowers and silvery white foliage. H. P.................................. 05 


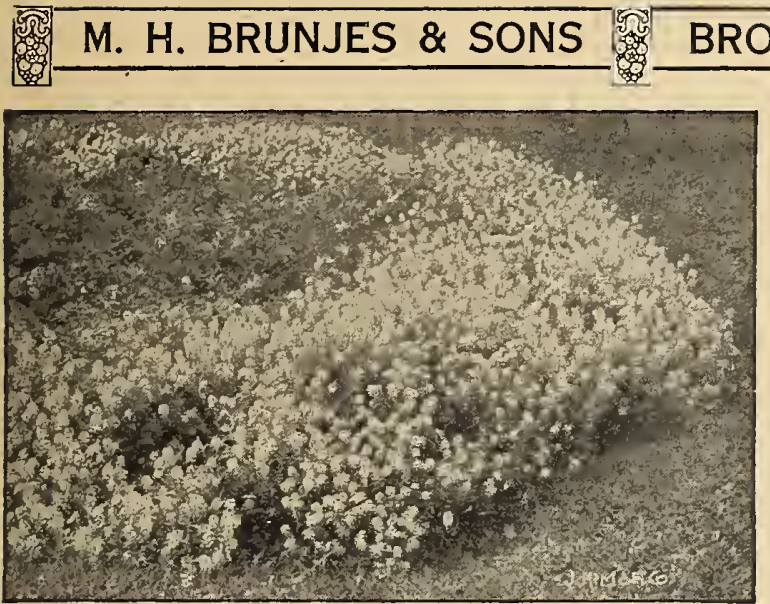

Alyssum, Carpet-of-Snow

\section{ALYSSUM}

Very desirable for edging. The seed germinates quickly and the pure white flowers begin to appear about one month later. The plants are dwarf, spreading, and continue to bloom sometimes as late as November. H. A

Carpet-of-Snow. The most popular variety of this superior

bordering plant, growing about 4 inches high, and blooming

continuously from spring until frost. The flowers are pure

white and as many as one hundred can be counted on a Pkt. Oz.

single plant at one time. ...................\$0 $10 \quad \$ 0 \quad 75$

Little Gem. A splendid sort growing somewhat higher than Carpet of-Snow.

Odoratum (Sweet Alyssum). Very fragrant, blooms freely, and its pure white flowers are fine for cutting. $\frac{1}{2} \mathrm{ft} \ldots \ldots \ldots 05$

Lilac Queen. A new annual variety of Sweet Alyssum, the plants being of upright growth and bearing pure lilac flowers., 10

Saxatile compactum. Bright golden perennial sort blooming early in the spring...

AMMOBIUM alatum grandiflorum. An annual white-

flowered Everlasting, which will be found useful for bouquets.

Grows about 2 feet high and prefers a light, sandy soil..... 05

AMARANTHUS. Ornamental foliage plants preferring a warm, dry situation. Their stately growth and brilliant-colored leaves present an attractive appearance when used for backgrounds or in the center of beds. H.H.A.

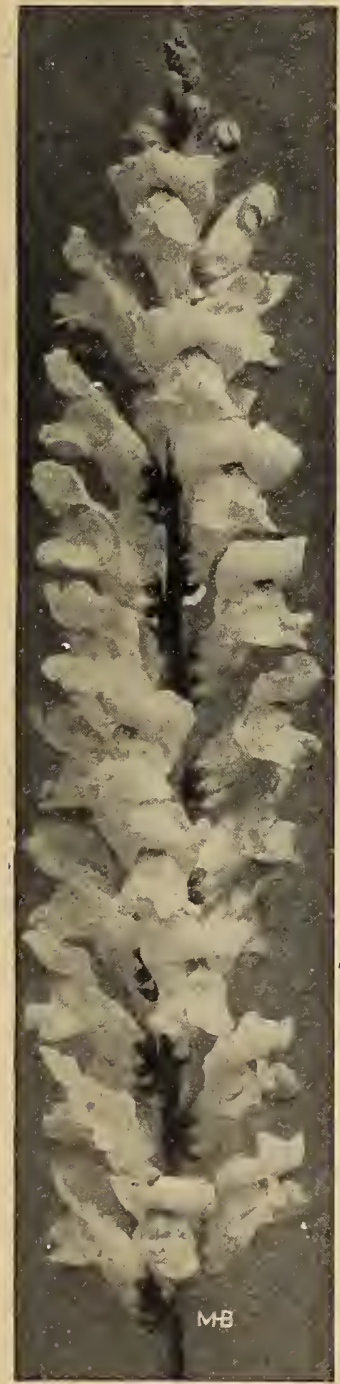

Giant-flowered Antirrhinum

Caudatus (Love-Lies-Bleeding). Plants about 3 feet high, with long, drooping --ikes of crimson Pkt. flowers.

Tricolor splendens (Joseph's Coat). Superior to the old variety; dazzling variegated foliage...

ANEMONE. Early spring-blooming plants with bright cup-shaped flowers. H.P. $1 \mathrm{ft}$.

Coronaria (Poppy Anemone). Finest mixed.

St. Brigid. An improvement on the preceding, producing double and semi-double flowers of immense size and many colors..........

\section{AN'TIRRHINUM (Snapdragon)}

The Snapdragon seems to do well in almost all gardens, especially if planted in a sunny position, and from July until frost its long spikes of flowers are borne in endiess profusion. For cutting, the tall varieties are recommended, while the dwarf sorts make frie plants for bedding. Seed sown in February and March will produce blooming plants by July.

\section{GIANT.FLOWERED ANTIRRHINUM (Height 3 ft.)}

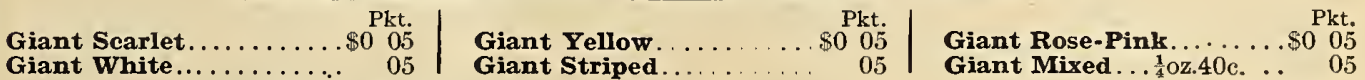

\section{TOM THUMB ANTIRRHINUM}

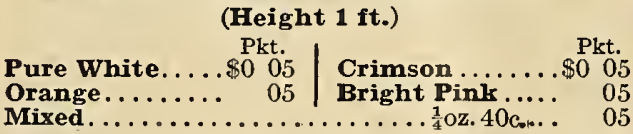

\section{GIANT.FLOWERED HALF-DWARF} A NTIRRHINUM

The half-dwarf Snapdragons are the finest of all for bedding and gencral garden planting. Growing about 18 inches high and blooming from July until frost, they afford fine cut-flowers all summer. Our mixture contains all the brightest and showiest colors.

Finest Mixed, $\frac{1}{4}$ Oz. $40 \mathrm{c}$, , pkt. 5c.

\section{AQUILEGIA}

One of our prettiest perennials, blooming in endless profusion from May until July. The odd-shaped flowers are unique in appearance and borne on slender stems well above the foliage.

Chrysantha. Attains a height of 3 feet and has Pkt.

beautiful golden yellow flowers............ $\$ 0$

Chrysantha fl. -pl. Double, long-spurred flow-

ers of a rich golden color............. 10

Cærulea. A variety of striking beauty; flowers

violet-blue and white. $2 \mathrm{ft}$.

Rose Queen. Long-spurred flowers, of a soft, delicate rose-pink color, with white centers and yellow anthers. A charming and very pleasing color combination. 15 inches.

\section{Single Varieties, Finest Mixed.}

Double Varieties, Finest Mixed.

ARABIS alpina. Splendid little plants for edging, growing 6 inches high and covered with a mass of small white flowers early in spring. H.P., $\frac{1}{4} \mathrm{oz} .25 \mathrm{c} .$.

ARCTOTIS grandis. This daisy-like annual is of easiest culture, blooms continuously until frost, and is splendid for cutting. Flowers white, reverse of petals pale bluc. $2 \frac{1}{2} \mathrm{ft}$...

1. $25 \mathrm{c} . . .05$

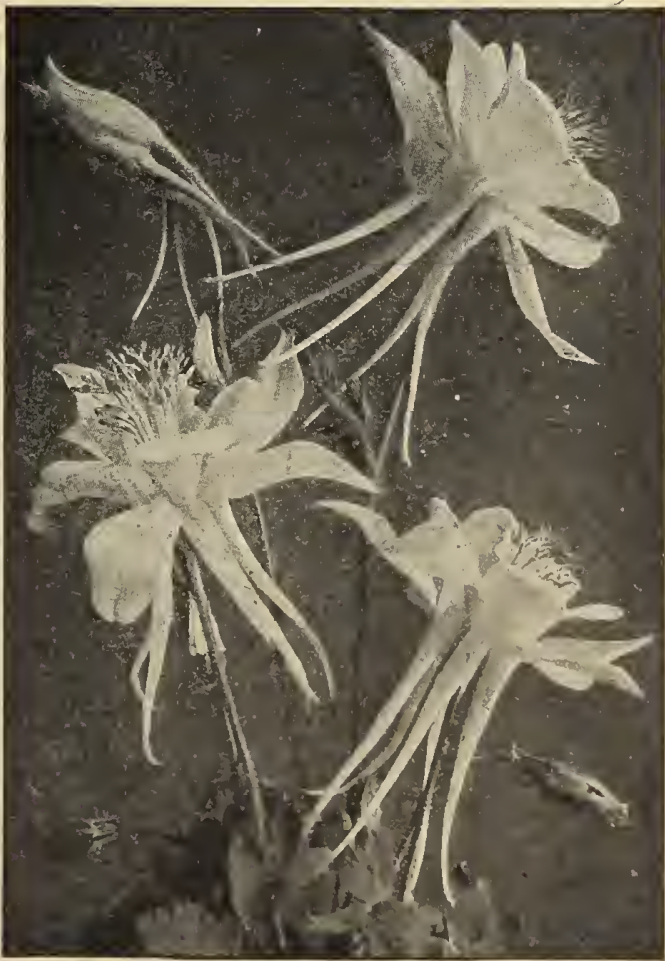

Aquilegia, Columbine 


M. H. BRUNJES \& SONS S BROOKLY

\section{Brunjes' Superb Asters}

The ever-increasing demand for this favorite flower surely proves its popularity with the florist and also for the home-garden. It has few superiors for cutting and ranks with the best annuals for bedding. For early flowers sow in frames during March and April, while for late-flowering, seed may be sown in the open ground in May. They prefer a sunny location, rich soil and, if possible, avoid planting them on the same place two years in succession. H.H.A.

\section{SIX KING ASTERS (INTRODUCTIONS)}

Everybody loves Asters, but we are sure the King Asters will more than please you. The flowers are of giant size and differ from other varieties in form as the petals are folded lengthwise, giving them a quilled effect. Be sure and try them.

Violet King. This famous variety is known the world over and no other flowers of immense size. Pkt. 10 cts., $\frac{1}{4} \mathrm{oz} . \$ 1$.

Crimson King. Another new variety of this grand Aster, which we are sure will prove equally as good and become just as popular as the two well-known varieties, Violet King and Rose King. The plants are strong and vigorous, of branching growth, and crowned with giant blooms of rich crimson. Pkt. 15 ets., 2 pkts. 25 cts.

Rose King. The stiff, strong petals of brilliant rose-pink are so formed as Rose King. completely to cover the crown, and the remarkable lasting qualities of the flower render it a most valuable sort for cutting. Pkt. $10 \mathrm{cts}$., $\frac{1}{4} \mathrm{Oz} . \$ 1$.

Lavender King. Flowers similar in every way to White King except in color, form, size and color. Pkt. 15 cts., 2 pkts. 25 cts.

White King. One of our largest and most valuable white Asters for cutting. soft, fluffy appearance, and their immense size and peculiar form make them strikingly handsome. Pkt. 15 cts., 2 pkts. 25 cts.

Pink King. A new shade in King Asters that will be welcomed by all lovers Pink King. of this class. Flowers of the same giant size and form as the preceding varieties, but in color a soft pleasing shade of blush-pink. Exception ally pretty in bouquets whether alone or with some of the darker colors. Pkt. 15 ets., 2 pkts. 25 ets.

Mixture of King Asters. Pkt. 15 cts., 2 pkts. 25 cts.

Collection, one packet each of the 6 King Asters, 60 ets.

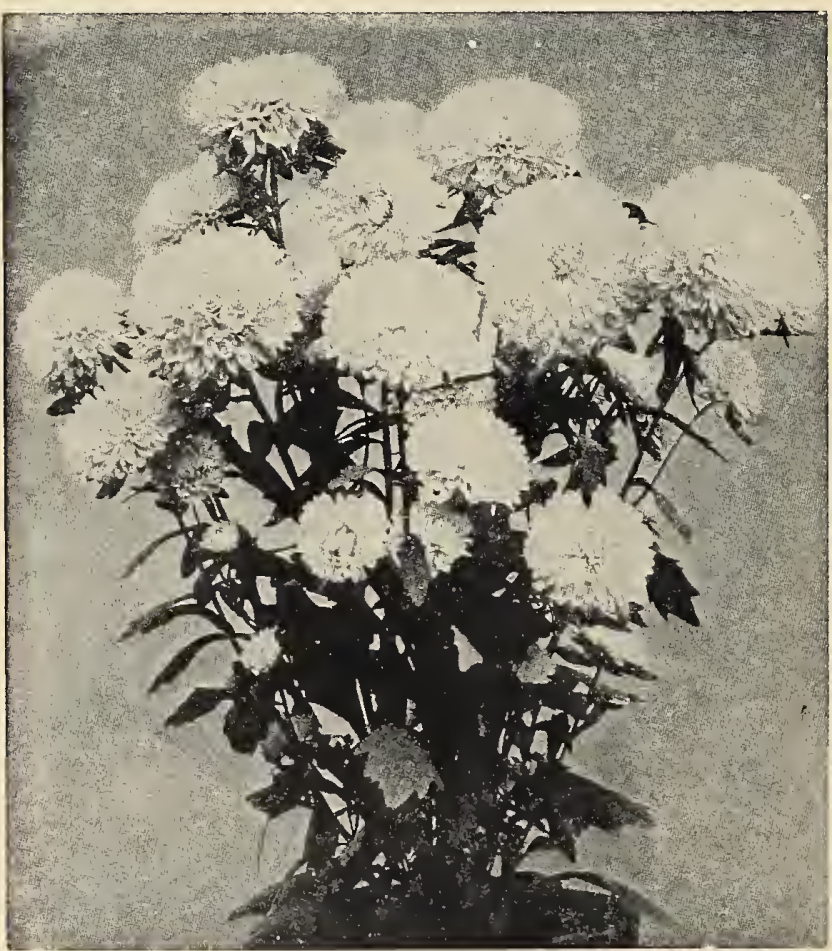

Giant Imperial Aster, Purity

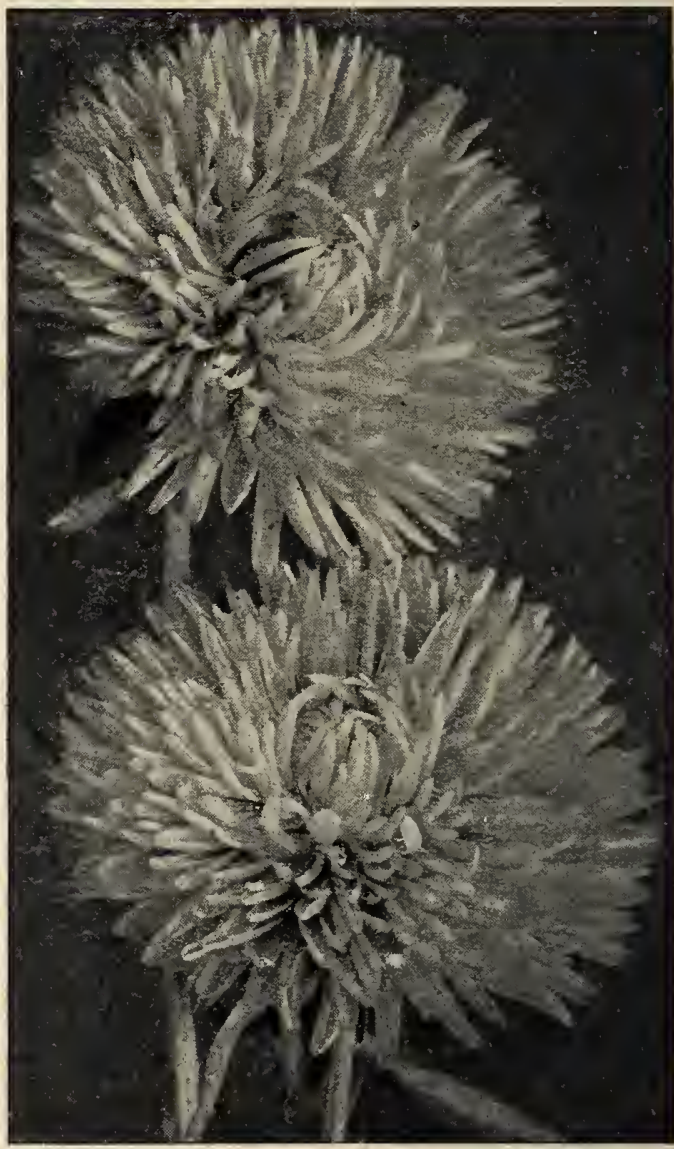

Violet King Asters

\section{GIANT IMPERIAL ASTERS}

These American Asters are greatly admired for their profusion of bloom and the doubleness of their flowers. They grow about 18 inches high and are especially adapted for massing and bedding purposes. Under good cultivation each plant bears from 40 to 50 large double flowers and we recommend them highly. Bloom in August.

Daybreak. Splendid early-blooming sort, having large, double, Pkt. 15 cts., 2 pkts. 25 cts.

Lavender Daybreak. A very popular and pleasing type of like those of the Daybreak and Purity. Plants strong, compact, and free-blooming. Pkt. 15 cts., 2 pkts. 25 ets.

Purity. Another magnificent Aster, similar in growth to Day15 cts., 2 pkts. 25 cts.

Rose Large, extremely double flowers of the Giant Imperial Rose. Large, extring during August and September. The deep rose-pink blooms are splendid for bouquets and vase decoration. Pkt. 15 cts., 2 pkts. for 25 cts.

Blue Bird. Very bright and showy. One of the finest blue 2 pkts. 25 cts.

Salmon. An odd shade of pinkish salmon, a color seldom seen Salmon. in Asters. Pkt. 15 cts., 2 pkts. 25 cts.

Violet. The darkest of all Imperial Asters. Flowers large and 1olet. handsome, very double and of a beautiful deep violet purple; a rich and attractive color. Pkt. 15 cts., 2 pkts. 25 cts.

GIANT IMPERIAL MIXED. Pkt. 15 ets., 2 pkts. 25 cts.

Collection, one packet each of the 7 colors, 75 cts. 


\section{H. BRUNJES \& SONS Bris}

\section{FOUR PRIZE-WINNING ASTERS}

Violet King. This famous variety is known the world over, and no other plolet King. Aster has won so many prizes. Beautiful, rich, violetpurple flowers of immense size. Pkt. $10 \mathrm{cts}$., $\frac{1}{4} \mathrm{oz}$. $\$ 1$.

Rochester White. Large, fluffy fiowers of the Comet type, borne freely The Rochester Asters are the largest in cultivation. Pkt. 15 cts., 2 pkts. 25 cts. Rochester Lavender-Pink. This is one of the finest free-blooming very long, and gracefully reflexed, forming massive, chrysanthemum-like flowers 4 to 5 inches across, of an exquisite shade of lavender-pink. Plants strong and robust, of branching habit, and come into bloom somewhat earlier than Late Branching. Pkt. 15 cts., 2 pkts. 25 cts.

Pink Enchantress. Flowers of a delicate pink, unusually large and rieties, at which season it is unsurpassed by any pink Aster. They are very attractive and always full and double. Pkt. 15 cts., 2 pkts. 25 cts.

Collection, one packet each of the above 4 varieties, 45 cts.

\section{NEW ROYAL ASTERS}

For a medium-early, large-flowered Aster try this new variety. In size and appearance the flowers resemble our Late Branching and like that variety it is

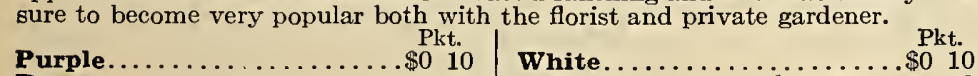

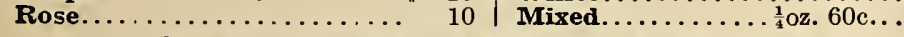
Collection, one packet each of the 3 colors, 25 cts.

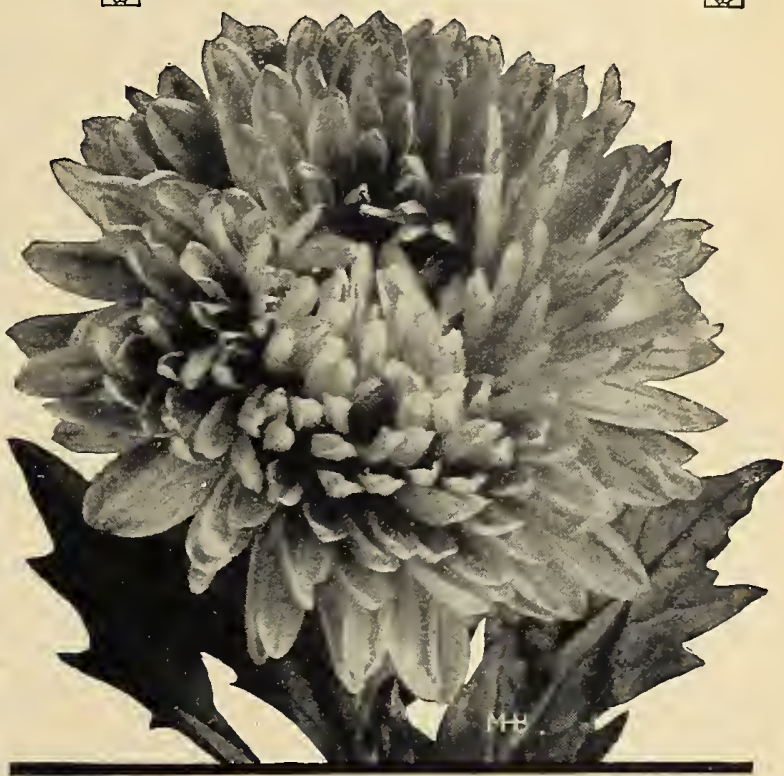

Late Branching Aster

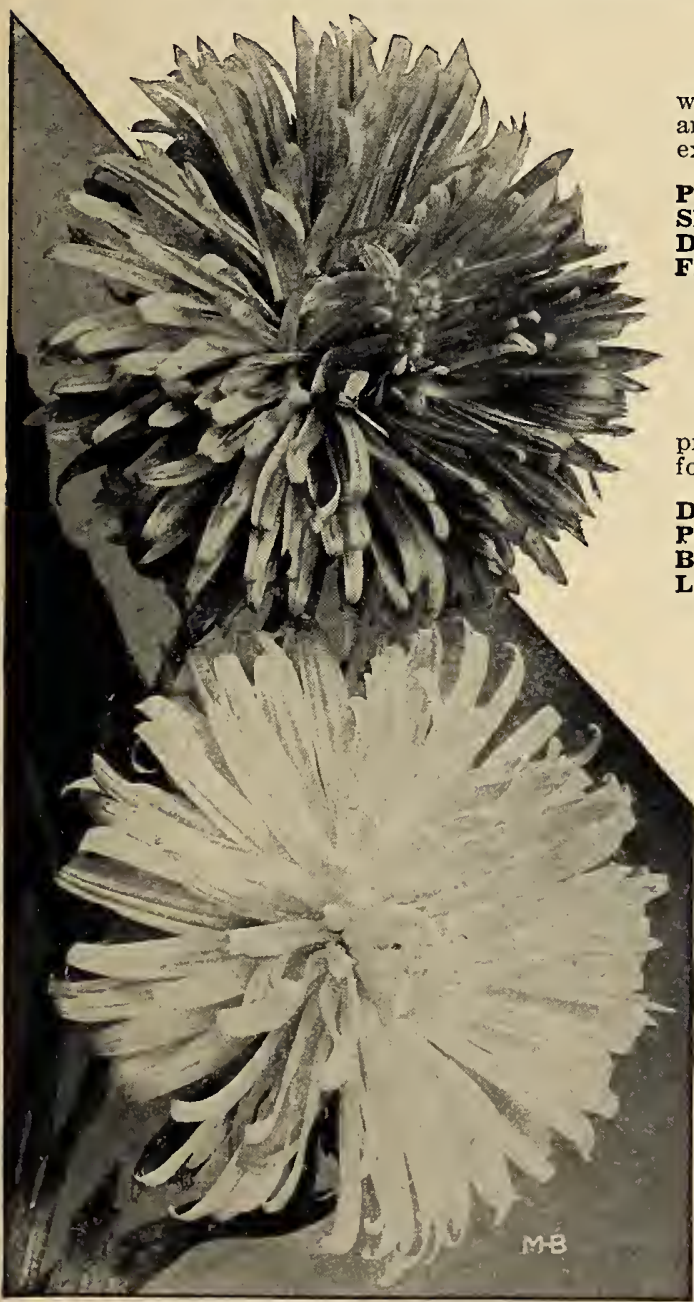

Crego's Giant Comet Asters

\section{LATE BRANCHING ASTERS}

There is no Aster more popular or so largely grown for late blooming as this well-known variety. The plants grow from 2 to $2 \frac{1}{2}$ feet high, are strong, well-branched and continue to bloom from the latter part of August until late in fall. The flowers are extra-large, beautifully formed, and borne on stiff stems, 15 to 20 inches in length.

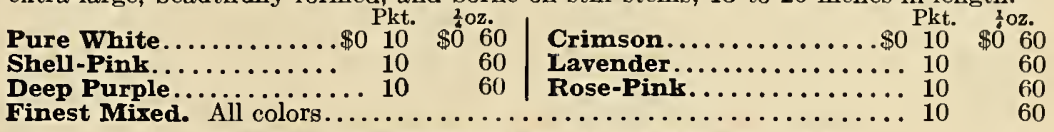

Collection, one packet each of the 6 colors, $40 \mathrm{cts}$.

\section{QUEEN OF THE MARKET}

This is one of the earliest Asters grown. The plants are of branching habit and produce flowers of rather large size and quite full to the center, which are splendid for cutting. Height 15 inches.

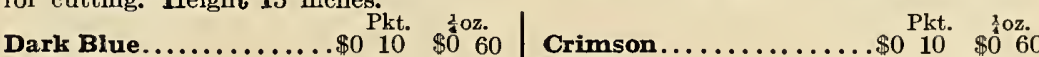

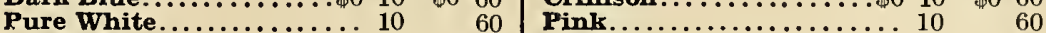

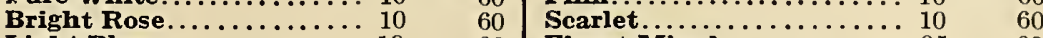

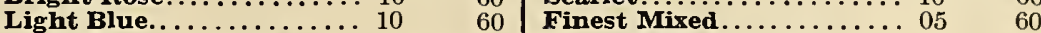

Collection, one packet each of the 7 colors, 50 cts.

\section{GREGO'S GIANT COME'T}

Undoubtedly the finest of all loose-petaled or feathered Asters, producing flowers of extra-large size, 4 to 5 inches across, which keep longer when cut than most varieties of this type. Ideal for cutting. $2 \mathrm{ft}$.

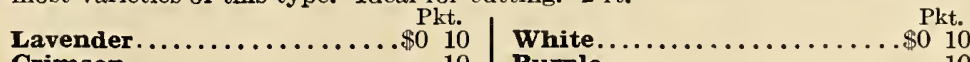

Crimson................. 10 Purple................... 10

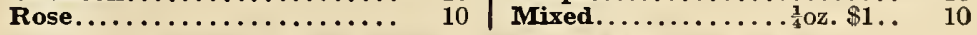

Collection, one packet each of the 5 colors, 40 cts.

\section{TRUFFA UT'S PEONY PERFECTION}

A splendid old-time favorite, known and planted everywhere. The plants form handsome upright bushes, $1 \frac{1}{2}$ to 2 feet high, and when in bloom appcar like a huge bouquet. Flowers full and double with incurved petals similar to those of a Peony and begin blooming in August.

Bright Rose.............\$0 10 Light Blue.............\$0 10

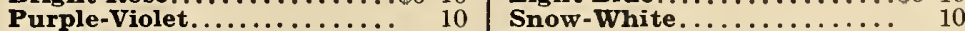

Dark Crimson .......................... 10 Mixed 10 Collection, one packet each of the 5 colors, $40 \mathrm{cts}$.

Our Aster Seed is grown by the best American and European 


\section{VIGTORIA ASTERS}

Our strain of Victoria Aster is very fine, and we recommend it highly as one of the best for the garden. The plants are of pyramidal growth, about 18 inches high, and are covered with large, extra-double flowers.

Finest Mixed. .$\frac{1}{4}$ Oz. $75 \mathrm{c} . . \$ 010$

ASTERS, CROWN, or COCARDEAU. The white-centered flowers are bordered with various brilliant colors. Very attractive. $1 \frac{1}{2} \mathrm{ft}$.

Finest Mixed.

ASTERS, DWARF, Chrysanthemum-flowered. For bedding, edging, and pot culture, this large-flowered, late-blooming variety is one of the best. Grows about 1 foot high.

Finest Mixed

Pkt.

SPARAGUS plumosus nanus Very popular decorative plant, with graceful, feathery, fern-like foliage. A splendid pot-plant for the conservatoly

Sprengeri. Just the plant for hanging-baskets, either for the house in winter or the porch in summer. Its drooping foliage is coarser than that of the $A$. plumosus nanus. $4 \mathrm{ft} . . \ldots \ldots \ldots \ldots 10$ AURICULA. See Primula.

BALLOON VINE. For covering fences and porches try this quickgrowing annual climber. The balloon-like seed-pods which follow the small white flowers are very interesting as well as attractive. $S \mathrm{ft}$

Double Rose-flowered Balsam

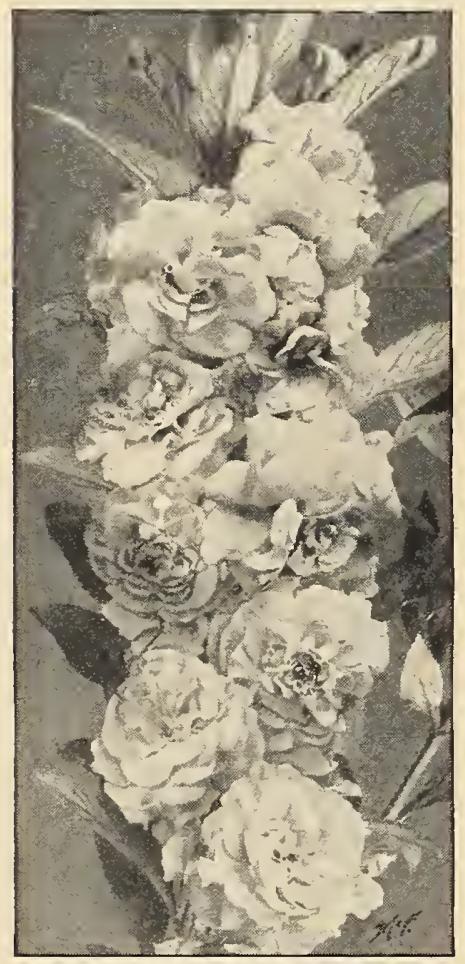

\section{BALSAM (Lady's Slipper)}

Very popular and exceedingly beautiful plants for massing in the flower-garden during the summer months. They produce gorgeous clusters of large, double, waxlike flowers abundantly in all shades of or more packets should be included in every order. H.H.A. $2 \mathrm{ft}$.

Double Rose-flowered. Handsome double flowers; plants 18 inches high. Mixed colors...... Pkt.

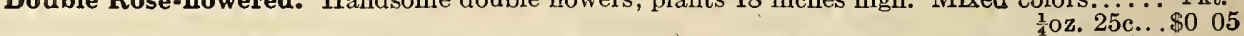
Double Camellia-flowered. A very fine strain of this well-known annual with extra-large, double flowers, including many beautiful striped and spotted ones. Finest mixed... $\frac{1}{4} \mathrm{oz} .30 \mathrm{c} \ldots 05$ BALSAM APPLE and PEAR. See Momordica.

\section{BEGONIA Fibrous-rooted}

The Begonia is one of the leading and most popular summer-flowering plants for bedding, and from June until late fall is an endless mass of bloom. Sow seed in January and February.

Gracilis luminosa. Large, fiery, dark scarlet Pkt. flowers; bronze foliage. Splendid bedder .....\$0 20 Semperflorens rosea. Rosy pink............. 10 Semperflorens, Vernon. Red; bronze foliage..... 10 BELLIS. See Daisy.

\section{CALLIOPSIS}

Favorite free-flowering annuals requiring no particular attention but thriving best in sunny locations. The tall varieties are splendid for cutting, and from seed sown in early spring you will have an abundance of flowers throughout the summer and early fall. Bright, showy flowers in yellow, brown, and crimson. Sow seed in early spring where plants are to remain.

Atrosanguinea. Dark crimson. $2 \mathrm{ft} \ldots \ldots \ldots \ldots \$ 0 . \ldots 5$ Coronata maxima. Showy, large yellow flowers, especially fine for cutting ........... 05 Drummondii (Golden Wave). Compact bushes are completely covered with bright golden yellow, dark-centered flowers. Very pretty border plant, also. Exceedingly effective when grown in masses . . . . . . . . . . . . . . . . . . . . . . . . . . . . . .

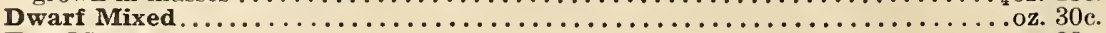

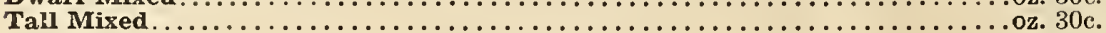

\section{GALENDULA (Pot Marigold)}

One of the brightest yellow-flowered annuals, thriving in almost any soil and producing on stout stems, large, double flowers of every known shade, from the lightest yellow to the deepest orange. $1 \mathrm{ft}$. H.A.

Orange King. Specially selected strain largely used by florists for cutting. Flowers very

double and of a rich, glistening orange. . . . .

Lemon Queen. Similar to the above; lemon colored flowers................... $25 c_{\ldots} \ldots 5$

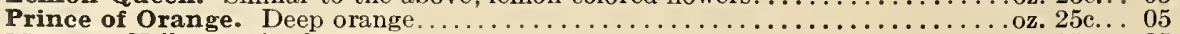

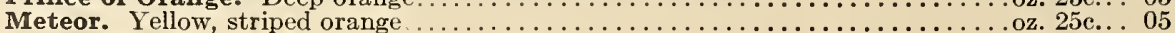

Double Mixed . . . .

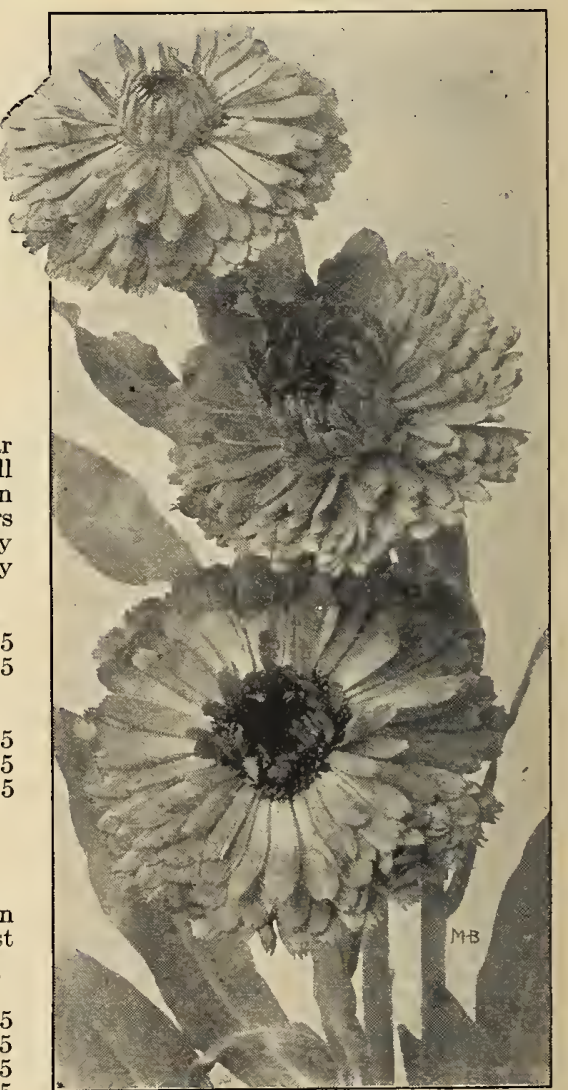

Orange King Calendula 


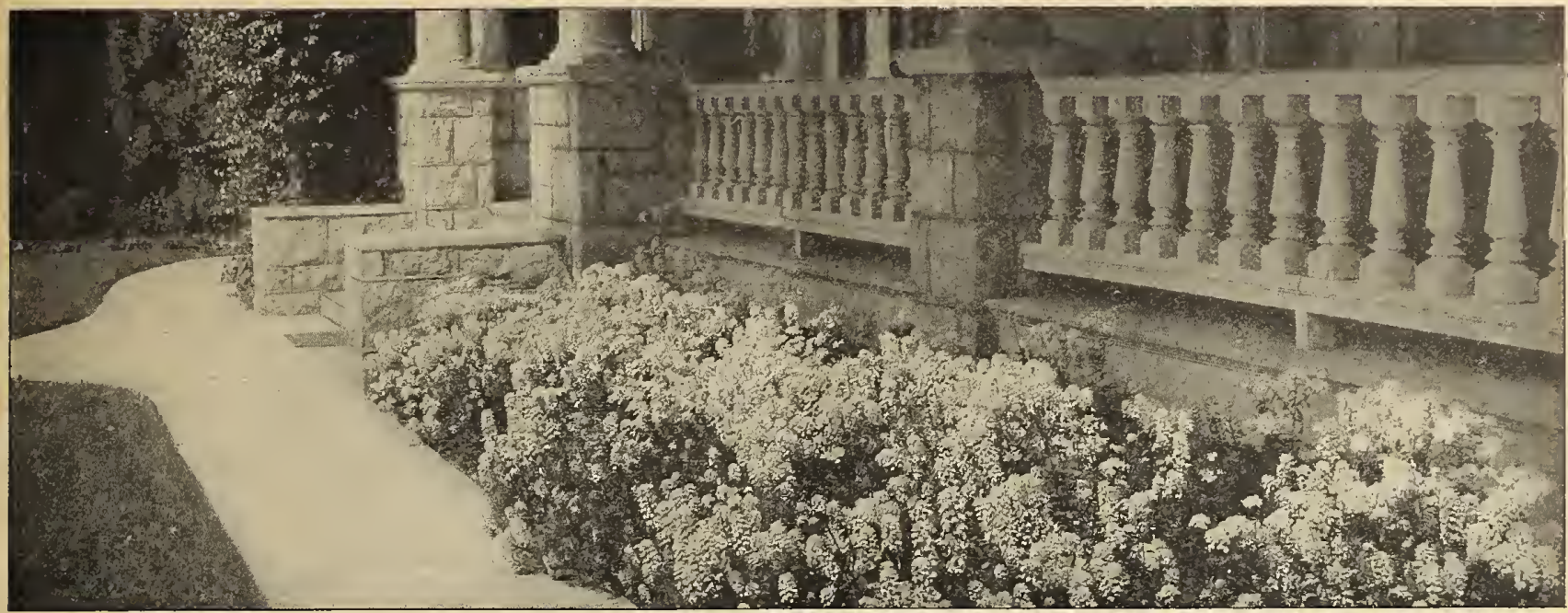

Candytuft, Empress

\section{GAMPANULA (Bellflower)}

There are quite a number of old-fashioned flowers, but this one seems to be a favorite with all. The blue and white bell-shaped flowers, blooming as they do in such great profusion, always attract attention. H. P.

Persicifolia (Peach Bells). A grand variety having large bell- Pkt. or cup-shaped blossoms. $2 \frac{1}{2} \mathrm{ft}$.

Finest Mixed. Blue and white.

Pyramidalis. The handsome showy flowers are borne on long stems about 5 feet high.

Blue..

White.

Finest Mixed.

$\$ 0 \quad 10$

\section{CANTERBURY BELIS}

(Campanula Medium)

Admirably adapted for borders, beds, or massing, and their countless number of beautiful flowers may be enjoyed during a long period. H. B. $2 \mathrm{ft}$. Pkt. Single Blue................ \$0 05 Single Rose.

05

Single Striped. . . . . . . . . . . . . 05

Single White................. 05

Finest Single Mixed....... $\frac{1}{4} \mathrm{oz} .25 \mathrm{c} . \ldots 05$

Finest Double Mixed........ $\frac{1}{4} \mathrm{Oz} .50 \mathrm{c} . \ldots 10$

Calycanthema (Cup and Saucer). The flowers of this interesting class of Canterbury Bells are not unlike a cup and saucer in appearance. They are very attractive, easily grown, blooming the second year from seed. Single plants will of ten have fifty or more flowers open at one time.

Finest Mixed......pkt. $10 \mathrm{cts}$, $\frac{1}{4} \mathrm{oz} .50 \mathrm{cts}$. CANARY BIRD FLOWER. See Tropæolum.

CALCEOLARIA. Gorgeous greenhouse plants with magnificent striped, mottled and selfcolored flowers of striking beauty. Sow seed during June or July. H. H. B. 2 ft.

Grandiflora, Finest Mixed. Tigered Pkt. and self-colored.............\$0 25

\section{CANNA}

Few plants surpass the Canna for centerpieces or bedding. Sow seed early indoors.

Crozy's Large-flowering. Fine Mixed. $\$ 005$

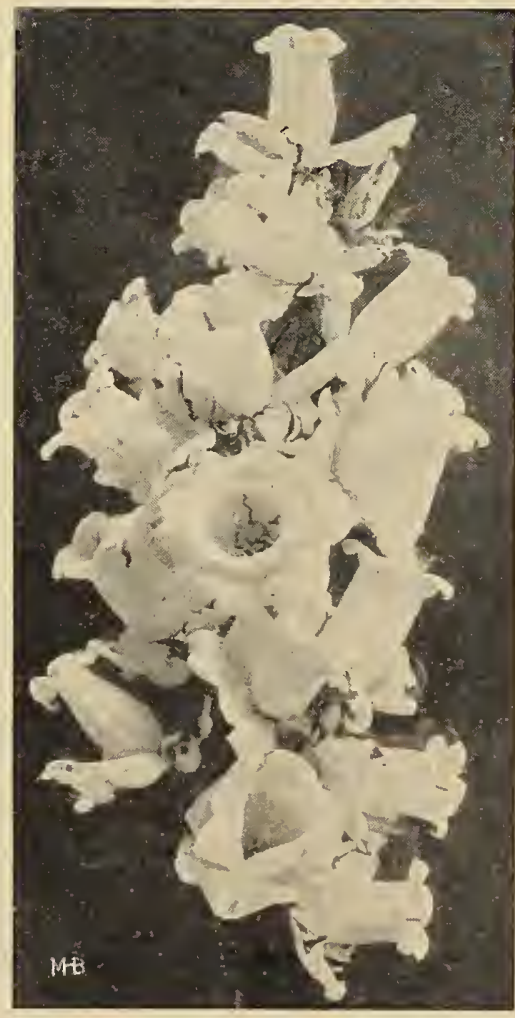

Campanula Medium (Cup and Saucer)

\section{GANDYTUFT}

Like alyssum, this hardy annual begins to bloom very early, and if several sowings are made at intervals, a supply of flowers may be had all summer. Almost any garden soil is suitable for Candytuft but a sunny position is preferred. The white-flowered varieties, Empress and Giant Hyacinth-flowered, are grown extensively by florists for cutting. Our stock of both is very fine.

Giant Hyacinth-flowered. Splendid for cutting; flowers of Pkt. largest size and purest white. $1 \mathrm{ft} \ldots \ldots \ldots \ldots \ldots$ oz. $50 \mathrm{c} \ldots$... 0005 Empress. Large heads of snow-white flowers......... oz. 50c... 05 Finest Mixed. All colors, including white, flesh-color, carmine, crimson, and lilac............................ 25c... 05 Dwarf Hybrids Mixed. Fine for borders. 6 in. .... $\frac{1}{4} \mathrm{oz} .25 \mathrm{c} . .05$ 


\section{H. BRUNJES \& SONS}

\section{CELOSIA}

Altogether a very ornamental class of plants, some with large, ruffled heads, resem bling a cock's comb and others with beautiful feather-like plumes. When well grown, the Cristata varieties are exceedingly handsome, while few flowers are more picturesque than the brilliant feathered sorts. H.H.A.

\section{GRISTATA（Gockscomb)}

Glasgow Prize. Splendid dwarf variety of immense size and rich crimson Pkt.

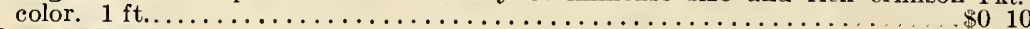

Dwarf Mixed .

\section{FEATHERED VARIETIES}

THOMPSONII MAGNIFICA. An exceptionally fine strain with large spikes of magnificent, plumed flowers which remain in bloom an unusually long time. They make excellent plants for bedding and their brilliant-colored plumes form a strik-

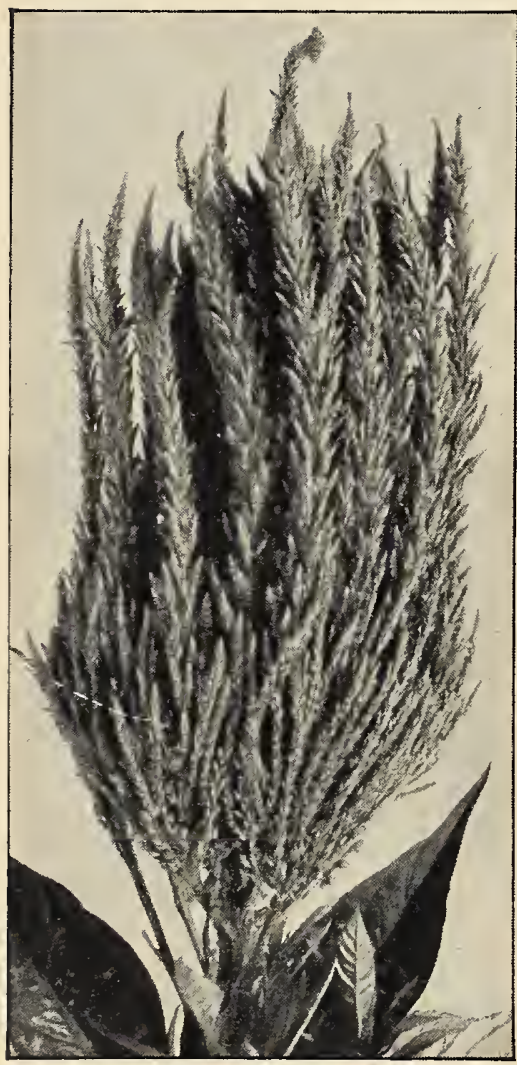

Celosia, Feathered ing contrast to the rich, green foliage. 2 to $3 \mathrm{ft}$.

Crimson.

Golden Yellow $\ldots \ldots \ldots \ldots \ldots, 10$

Finest Mixed. . . . . . . . $\frac{1}{4} \mathrm{oz} .40 \mathrm{c} . .10$

\section{Pride of Castle Gould}

A superior strain of Celosia, admired for its large, feathery plumes, which vary in color from the deepest blood-red to carmine, salmon, orange and yellow. Very decorative when grown in pots, and most valuable for bedding, blooming from August until frost. Seed sown in March makes fine plants for setting out in May. 2 to $3 \mathrm{ft}$. Mixed colors. Pkt. $15 \mathrm{cts}$. 2 pkts. 25 ets.

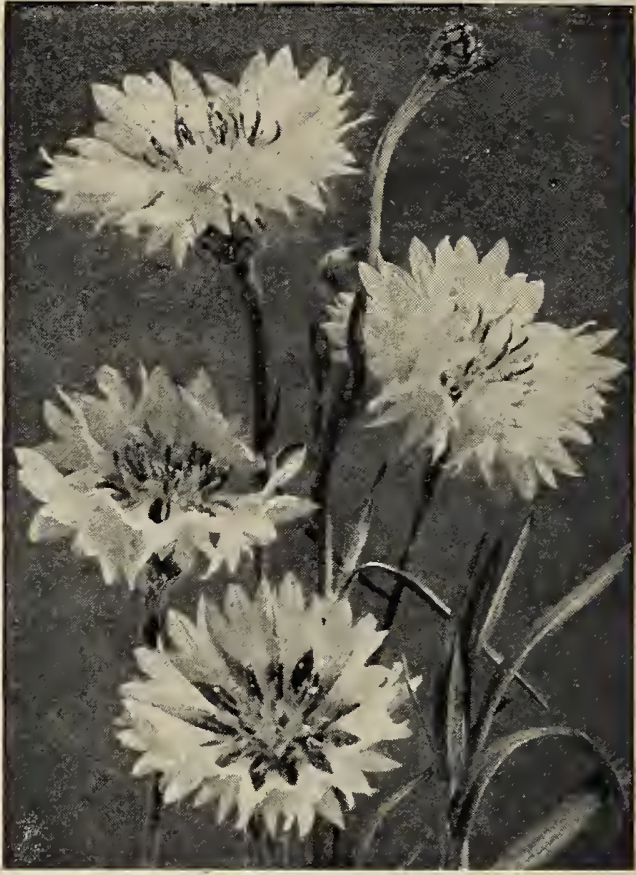

Centaurea Cyanus. Cornflower

\section{CENTA UREA}

Hardy annuals, of easiest culture, bearing long-stemmed, bright-colored flowers, which are favorites both for the garden and as cut-flowers. The common Cornflowers (Centaurea Cyanus) are most desirable for the old-fashioned and wild flower gardens. $2 \mathrm{ft}$.

\section{GYA NUS (Cornflower)}

Single Blue. Finest blue for cutting.

Single, Finest Mixed.............. $35 . .$. Double Blue. Very fine for cutting. Double-flowered, Mixed........ oz. $50 \mathrm{c}$.

\section{GIANT SWEET SULTANS}

These giant Cornflowers are indispensable for cutting and vase decoration. Their sweet-scented flowers are borne on long, stout stems and average 3 to inches in diameter. $2 \mathrm{ft}$. $\mathrm{Pkt}$. IMPERIALIS alba. An excellent white variety for cutting.......\$0 10 Finest Mixed ................. 10

\section{CHRYSANTHEMUM}

Splendid single and double annuals, the flowers of which are quite large and very effective in bouquets. The plants, 2 feet high, are easily raised from seed and deserve a place in every garden.

\section{ANNUALS}

Carinatum, Single Mixed Carinatum, Double Mixed z. $50 \mathrm{c} \ldots \$ 005$ oz. $50 \mathrm{c} . .05$

Morning Star. Early, profuse-blooming plants with large, daisy-like flowers,

borne on strong stems and of a beautiful cream-yellow color. $1 \frac{1}{2} \mathrm{ft} . \ldots \frac{1}{1} \mathrm{oz} .15 \mathrm{c} . \ldots 05$

Evening Star. Rich golden yellow flowers, 3 inches across; very fine for cutting. Grows about $1 \frac{1}{2}$ feet high..

Inodorum plenissimum. This garden gem is crowned with small double snow-white flowers until frost.

\section{PERENNIALS}

Frutescens (Marguerite, or Paris Daisy). White, star-shaped flowers; a desirable

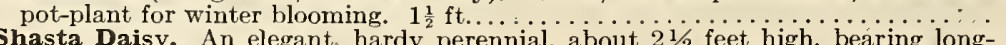
hasta Daisy. An elegant, hardy
stemmed, single, white flowers.

\section{0}

Pkt.

05

05

05

\section{WHITE-LEA VED}

\section{GENTA UREAS (Dusty Millers)}

For borders and ribbon beds these whiteleaved plants are very useful and exceedingly

attractive. $1 \mathrm{ft}$. Pkt. Candidissima. Silvery white foliage. . $\$ 010$

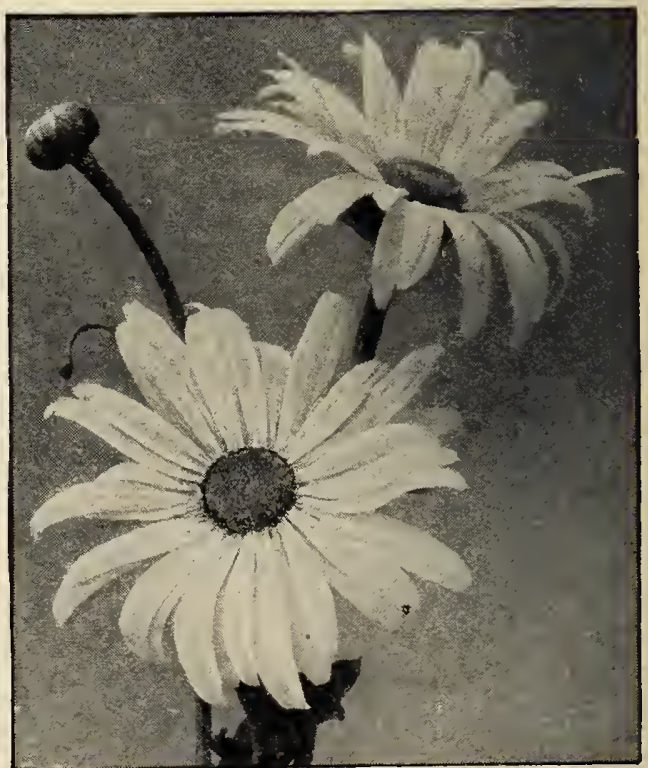

Chrysanthemum. Shasta Daisy 


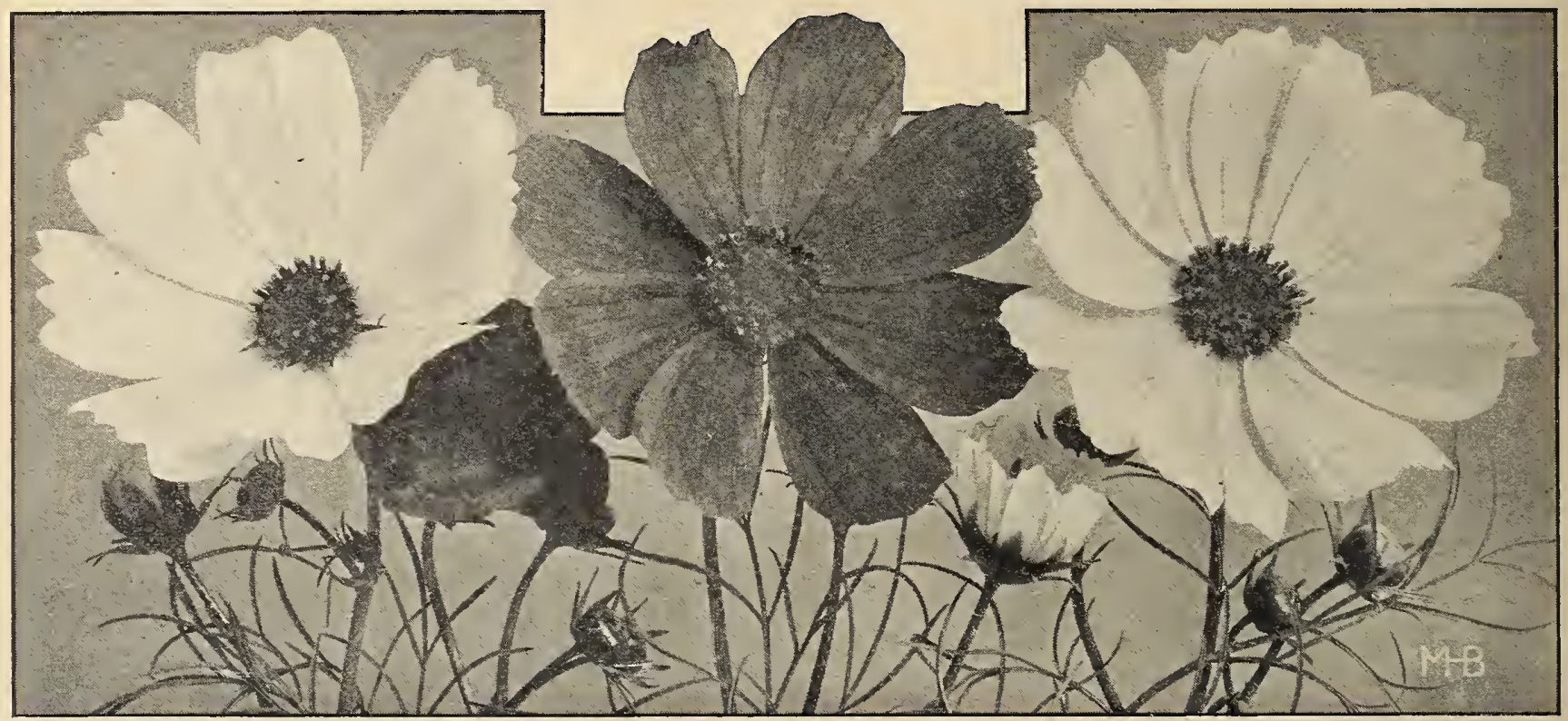

Mammoth Perfection Cosmos

\section{COSMOS}

During the fall months, when most flowers are through blooming, the Cosmos appears in all its glory. The strong, sturdy plants, from 4 to 6 feet high, form splendid backgrounds and are literally covered with hundreds of large, single, dahlia-like flowers. Ideal for cutting and decorating, the fine-cut feathery foliage and bright-colored flowers contrasting to perfection. H.A.

\section{MAMMOTH PERFEGTION}

The flowers of this superb strain are of gigantic size and exceptional beauty. Sow the seed outdoors in May, or preferably under glass in March. $6 \mathrm{ft}$. Pkt. ${ }^{\frac{1}{2} \mathrm{oz} .}$.

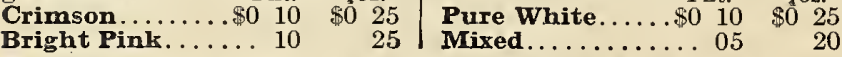
Klondyke. Should be started early to obtain blooming plants;

golden yellow flowers, 2 to 3 inches across.............. 10

\section{LADY LENOX COSMOS}

This is a great improvement on all other varieties of Cosmos. The plants are of strong, vigorous growth, attaining a height of 6 to 7

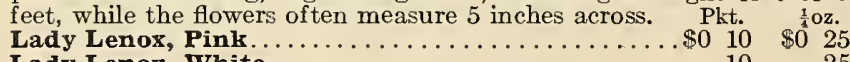

Lady Lenox, White.

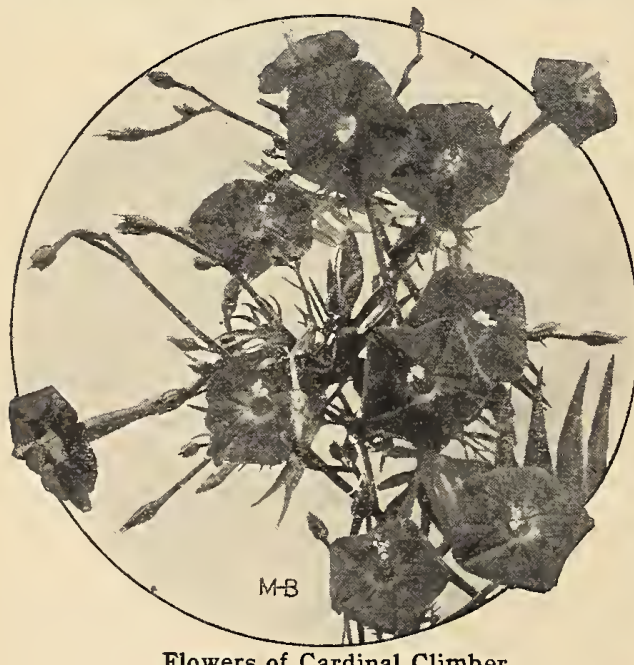

Flowers of Cardinal Climber

\section{LARGE EARLY.FLOWERING GOSMOS}

The dwarf, early-flowering Cosmos is becoming very popular, and while the flowers are not so large as the Mammoth strain, they appear at least a month earlier. $4 \mathrm{ft}$. Pkt.

Pink. .............\$ 10 Crimson............\$0 10 White (Dawn) ........ 10 Mixed.......... $\frac{1}{4}$ oz. 25c... 05 CUPHEA platycentra (Cigar Plant). Very fine plants for pots

and borders, about 1 foot high, continuing in bloom until fall.

Scarlet and purple, tube-shaped flowers. H. H. P.......... 10

\section{CYPRESS VINE (Ipomoea Quamoclit)}

A splendid annual climber for covering arbors, trellises, etc. The bright star-like blossoms of scarlet and white appear in endless profusion and with the delicate, feathery foliage form a very charming effect. Grows 12 feet high. Mixed colors. Oz. 30 cts., pkt. 5 cts.

\section{THE CARDINAL CLIMBER}

A most beautiful anual climber of rapid growth, blooming profusely from midsummer until frost. The vines easily grow 20 to 30 feet high and the fine, fern-like foliage is literally covered with dazzling, fiery red tubular flowers which measure about $1 \frac{1}{4}$ inches in diameter. Prefers a warm, sunny location and should be sown in rich soil. Do not fail to try it. Pkt. $15 \mathrm{cts.}, 2$ pkts. $25 \mathrm{cts}$.

\section{GYCLAMEN}

The Cyclamen is among the prettiest of winter-blooming plants, possessing handsome foliage and magnificent, rich-colored flowers. From September to February is considered the best time to sow the seed, which will produce blooming plants in about one year.

Giant-Flowering, Mixed........ \$0 25

\section{DAHLIA}

Though Dahlias are more largely grown from bulbs, they may also be raised from seed and if sown during March (indoors) they will bloom the first season. The single varieties are somewhat earlier than the double and may be sown as late as May. H. H. P.

Double Dwarf Large-Flowering, Pkt. Mixed ................... 10 Double Cactus. This mixture includes many beautiful varieties........... 10 Single Lucifer. Maroon-black leaves and rich, dazzling scarlet flowers.... 10

Single Tom Thumb. All colors.... . 10

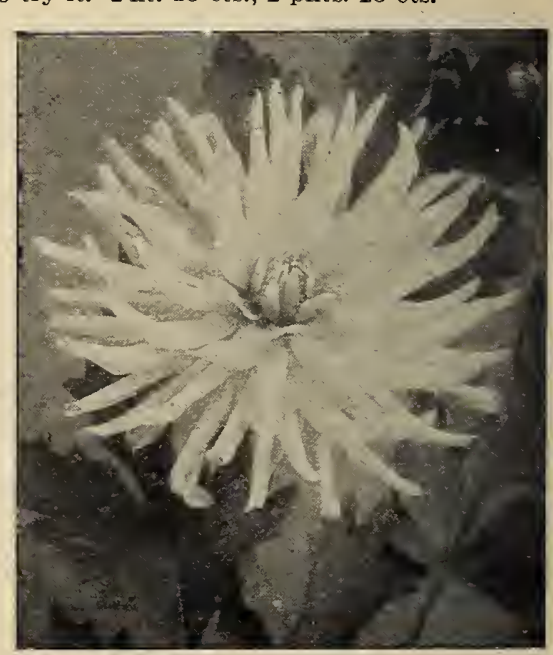

Cactus Dahlia 


\section{H. BRUNJES \& SONS B. BROOKLYN, N. Y. W RELIABLE SEEDS}

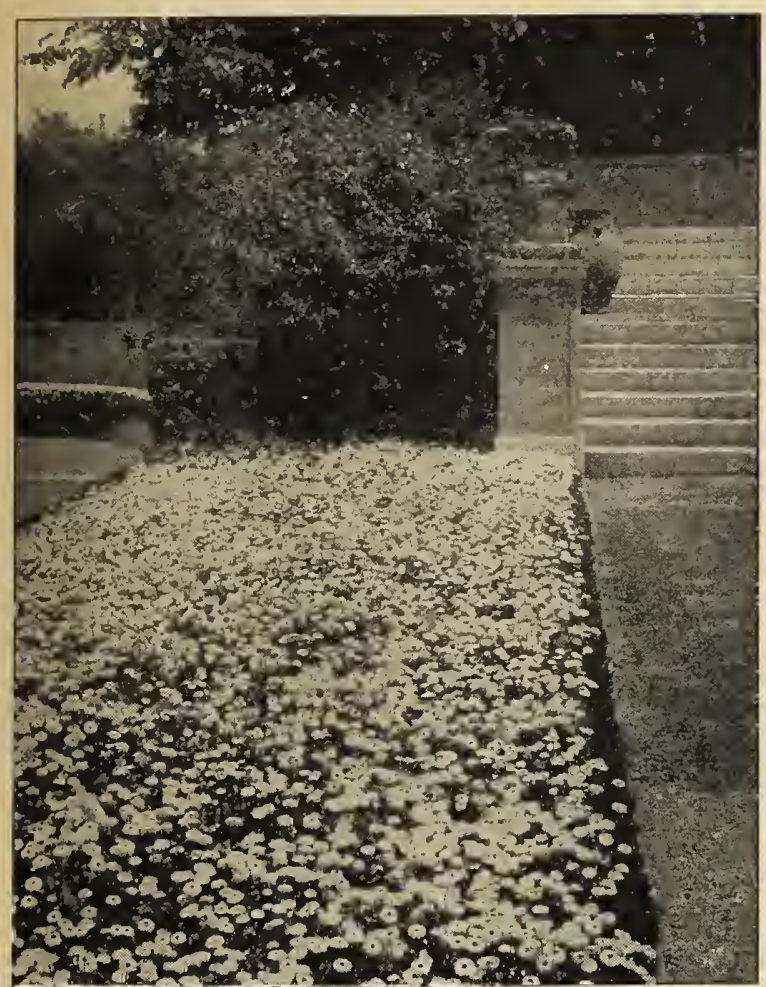

Daisies (Bellis perennis)

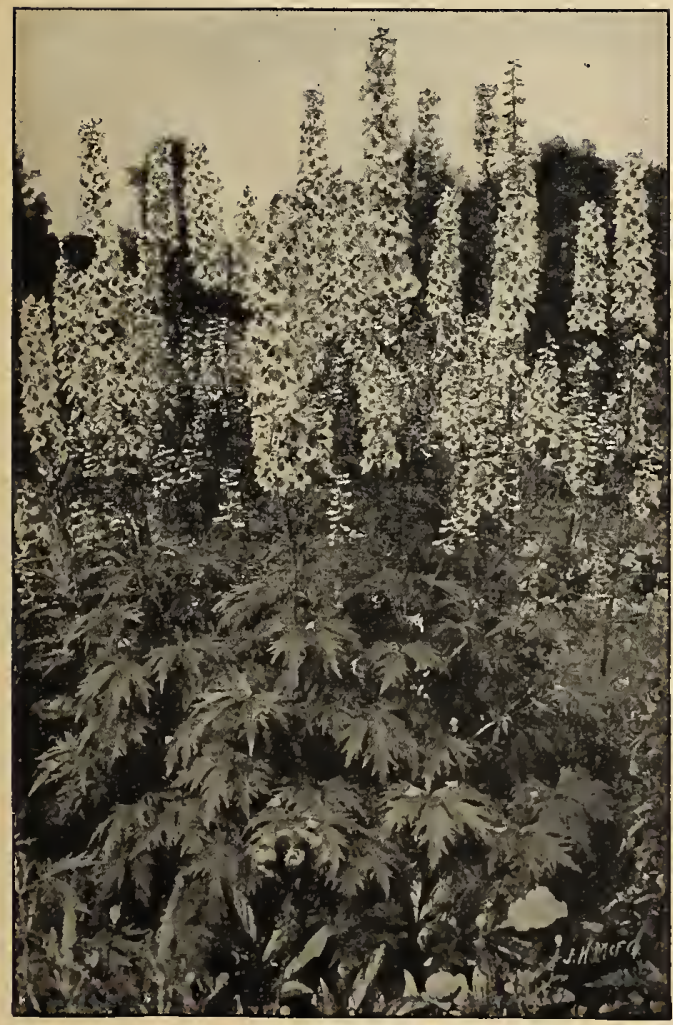

Delphiniums, Large-flowering Hybrids

\section{DOUBLE DAISY (Bellis perennis)}

One of the prettiest spring flowers so largely used for bedding with pansies. They do not exceed 6 inches in hcight, and like the pansy, bloom continuously until hot weather. Seed may be sown in spring, but July and August are preferred. Protect with leaves, or better still, winter over in coldframes. H. H. P.

Longfellow. The popular double pink variety; free bloomer........\$0 io

Snowball. Beautiful double pure white...................... 10

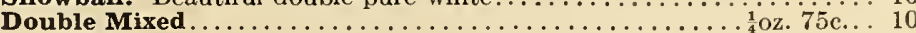

\section{MONSTROSA, or GIANT DOUBLE DAISIES}

This new strain of the well-known double Daisy is far superior to the older varieties. The flowers, while not produced quite so abundantly, are very much larger, extra-double and resemble small asters. MONSTROSA alba. Flowers of the purest white........... 8020

Rosea. Deep rose-pink

Mixed. White and pink

$\frac{1}{8} \mathrm{Oz} . \$ 1.25$ 20

DAISY, Shasta. See Chrysanthemum.

DATURA (Trumpet Flower). Plants 2 to 3 feet high, of strong, branch-

ing growth, with large, sweet-scented, trumpet-shaped flowers. H. H. A...

Cornucopia (Horn of Plenty). Fragrant, single white and purple flowers; excellent variety

Golden Queen. Rich double golden yellow.

Double Mixed. Various colors....

\section{DELPHINIUM (Hardy Larkspur)}

A bed or border of Delphinium is very impressing. The plants are strong, and stately, with long spikes, carried well above the rich, green foliage each thickly studded with brilliant flowers of every shade from the lightest blue to the deepest purple. Seed may be sown early, thereby securing flowering plants the first season. H. P.

Large-flowering Hybrids. A very fine, large-flowered,

2 to 3 feet in length and ranging in color from sky-blue to the deepest Pkt. purple. $4 \mathrm{ft}$. ............................. 10 Double-flowering Hybrids. Immense spikes of beautiful double flowers,

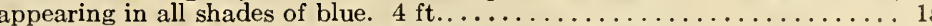

Elatum (Bee Larkspur). Dark blue, center almost black. $4 \mathrm{ft} \ldots \ldots \ldots \ldots \ldots 10$

Formosum. One of the prettiest Delphiniums; the flower spikes are rich, velvety blue with clear white center. Plants about 3 feet high.

Formosum cœlestinum. Dainty sky-blue flowers; very striking. $3 \mathrm{ft} \ldots \ldots .10$ Zalil (Hardy Yellow Larkspur). Quite distinct from all other hardy Lark-

spurs; sulphur-yellow. $4 \mathrm{ft} \ldots \ldots \ldots \ldots \ldots \ldots \ldots \ldots \ldots \ldots . \ldots \ldots$
Chinense. Pretty garden plants $1 \frac{1}{2}$ feet high, with fine, feathery foliage and numerous spikes of bright-colored flowers, Mixed.

\section{DIGITALIS (Foxǵlove)}

The Foxglove is perfectly hardy and from June until August the tall spikes of gloxinia-like flowers are the admiration of all. They are fine when used as a background for dwarf plants or scattered among shrubbery, succeeding best in partially shaded positions. Sow the seed from May until August. 2 to 4 feet.

Gloxiniæflora. Handsome spotted flowers compactly formed on spikes 2 feet Pkt. in length. Splendid for herbaceous borders and a general favorite for the old-fashioned garden. All colors

Purpurea. The common variety so often seen in the hardy border, and while not so large as some of the newer varieties, a few plants are always welcome. Finest mixed

Maculata superba. Admired for its beautiful spotted flowers.

Monstrosa. Flowers large and attractive, bell-shaped, and of exquisite Onstrosa. beauty. Both the spikes and individual flowers are of extraordinary size and unlike the preceding varieties, each spike terminates in one enormous saucer-like blossom. Finest mixed

DIMORPHOTHECA aurantiaca (African Golden Daisy). This showy, freeblooming annual, recently introduccd, will, before long, be one of our garden favorites. The plants, of dwarf, branching growth, are covered with Daisylike flowers, of a rich orange color with black zonc, which on sunny days glitters like gold

DOLICHOS Lablab (Hyacinth Bean). A splendid climber with dense foliage for training over trellises, etc. The purple and white pea-shaped flowers are produced in clusters and appear throughout the summer. $10 \mathrm{ft}$. T. A. Purple and White, Mixed

DRACAENA indivisa. An ornamental plant with long, narrow, green leaves, growing $2 \frac{1}{2}$ feet high. Used for centerpieces in vases or flower-beds. G. P.. 


\section{Dianthus, or Pinks}

A most satisfactory class of plants widely cultivated for their brilliantly colored flowers. The bushes are of compact growth, 12 to 18 inches in height, most easily grown and in continuous bloom until frost. The double Pinks are very pretty, quite similar to carnations and measure $1 \frac{1}{2}$ inches across. Seed should be started indoors as early as possible, preferably in March or April, while outdoor sowings should be made about May. Suitable for planting either in beds or borders.

\section{DOUBLE ANNUAL PINKS}

Chinensis, Double Mixed (China Pink). The favorite garden pink; flowers of me- Pkt. dium size, very double and fine for bouquets.

Mourning Cloak (White Frill). Rich, velvety crimson, edged white........ 10

Diadematus fl.-pl. (Diadem Pink). A very fine strain of this popular annual producing large, extremely double, fringed flowers in a grand assortment of colors. .

Fireball. Very effective; brilliant dark scarlet. Splendid for cutting.

Heddewigii fl.-pl. (Double Japan Pink). A superior mixture, including Pkt. many beautiful colors. The largest and best of the double-flowering Pinks.....\$0 05

Snowdrift. Handsome snow-white flowers with fringed petals. Large, very full and double.

Laciniatus, Double-Fringed. These splendid, large-flowering, annual Pinks are fine for cutting and bouquets. The flowers are very double with petals nicely fringed.

\section{SINGLE ANNUAL PINKS}

Princess Pinks. The flowers of this single Pkt. Dianthus are richly marked, spotted and striped in a great variety of colors. $\$ 010$

Heddewigii ( $\mathrm{J}$ a p a n Pink). A favorite and one of the prettiest varieties. All colors mixed...

Laciniatus. Beautifully fringed flowers, including all colors from pure white to darkest crimson....

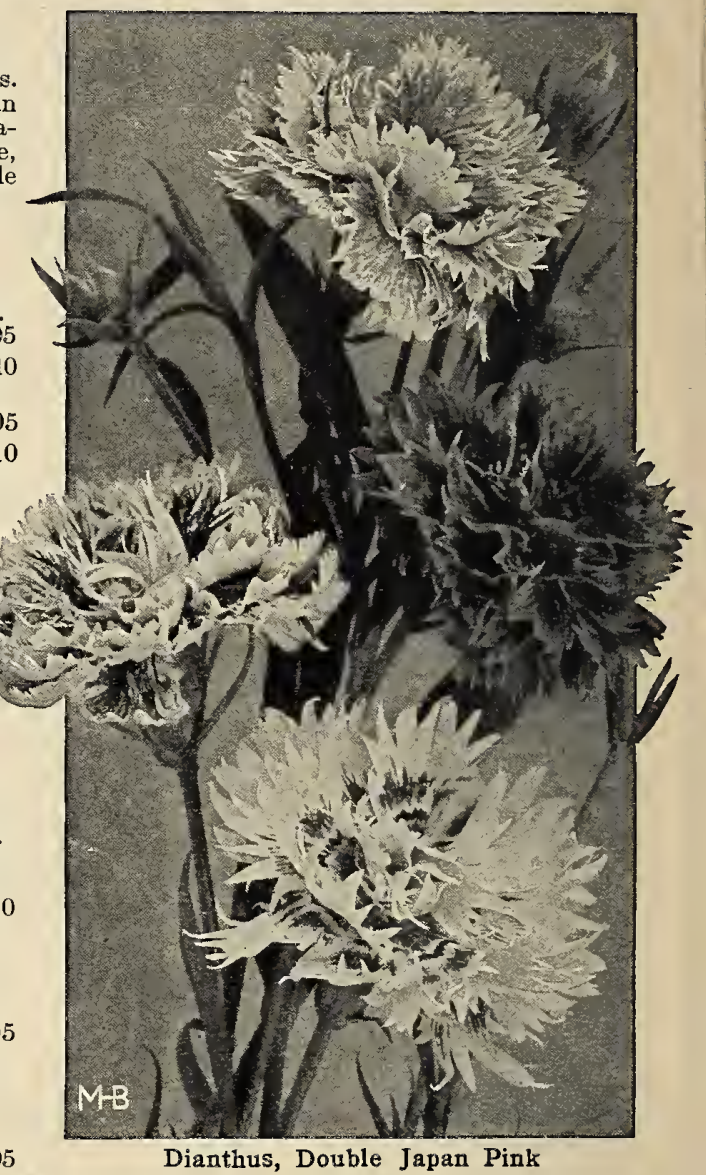

\section{HARDY PERENNIAL PINIKS}

It is in May and June that these hardy Pinks are at their best and during that period the plants are literally smothered with bright-colored, delightfully fragrant flowers. Seed may be sown from May to August and as the plants are very hardy they will winter over with little protection. We would suggest planting a few of these Hardy Pinks which are deserving of a place in every garden.

Plumarius fl.-pl. Splendid for hardy borders. Blooms freely and is fine Pkt.

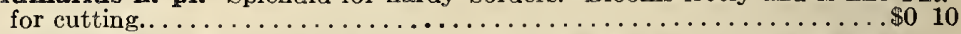

Semperflorens (Everblooming Pink). The double and semi-double flowers are sweet-scented and range through many colors.................

Plumarius nanus fl.-pl. This charming Pink grows but 1 foot high, blooms somewhat earlier than the preceding, and the flowers possess a

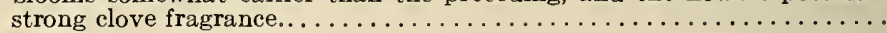

\section{ESGHSGHOLTZIA (Galifornia Poppy)}

The California Poppy is a most desirable flower for bedding. The plants, about 1 foot in height, have fine-cut foliage and may be seen in bloom all through the summer with single, poppy-like flowers, which range through shades of orange, yellow, crimson and white. It is best to sow the seed in the garden where the plants are to remain, as they do not transplant easily. The beautiful State flower of California.

Californica. The favorite bright yellow ............. 50 cts. $\$ 005$ Carmine King. Very effective in beds. Both the outside and inside of petals are rich carmine..

Crimson king. A handsome, free-blooming variety with lovely rosy

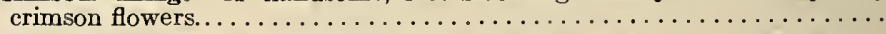
Golden West. Flowers of bright, golden yellow; splendid for bedding....

Oz. 50 cts... 05

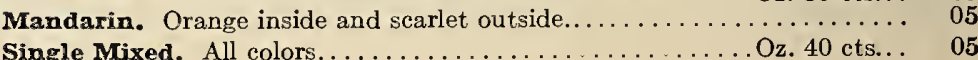

Digitalis (Foxglove). See page 39.

Single Mixed. All colors. 


\section{H. BRUNJES \& SONS BROOKLYN, N. Y. RELIABLE SEEDS}

ECHINOCYSTIS lobata (Wild Cucumber Vine). Of rapid growth, attaining a height of Pkt. 20 feet or more in one season, and affording a most desirable covering where shade is

desired. Small, white, fragrant flowers followed by ornamental seedpods. H.A. oz. $30 \mathrm{c} . . \$ 005$

EUPHORBIA variegata (Snow-on-the-Mountain). Readily grown in any garden. They grow 2 to 3 feet high, are very ornamental and from early summer until frost the green and white margined leaves attract unusual attention. Sow seed early and later set plants 1 foot apart. H.A.................................. 40c., pkt. $5 \mathrm{c}$

FORGET-ME-NOT. See Myosotis.

FOUR O'ClOCK. See Marvel of Peru.

FOXGLOVE. See Digitalis.

\section{GAILLARDIA}

Bright, showy annuals, blooming freely and continuously through the summer. The flowers, varying from 2 to 3 inches in diameter, are borne on long, slender stems, and while red and yellow are the prevailing colors, pink, white and salmon are also included.

Picta, Single Mixed. Very fine. .

Picta Lorenziana, Double Mixed. .

\section{PERENNIAL GAILLARDIA}

A well-recommended perennial for the hardy border which, if left undisturbed for several years forms large clumps 2 feet across. Flowers are similar to but larger than the annual varieties and equally good for cutting.

Grandifiora, Mixed. Fine, large-flowered sort.

Pkt.

Grandiflora compacta. Handsome, dwarf-growing variety with briliantiy colored flowers,

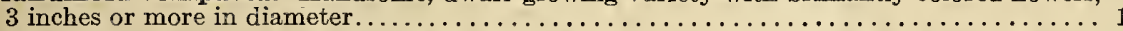

GERANIUM zonale. The plants will produce flowers the first year if the seed is sown

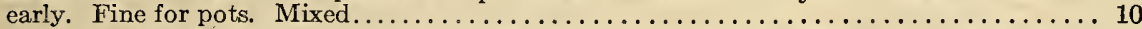

GLOBE AMARANTH (Gomphrena). This pretty annual everlasting, known also as Straw Flower and Bachelor's Button, makes a splendid border or bedding plant, and its clover-like flowers when dried are prized for bouquets. $2 \mathrm{ft}$. Finest Mixed...

GODETIA. Splendid for massing. The large, satiny flowers are produced so profusely that the plants are at times almost hidden from view. They prefer a light, sandy soil. H. A. $1 \mathrm{ft}$. Mixed. All colors...................................... 05 Ornamental Grasses. Form very attractive beds, either alone or together with other is both odd and beautiful. plants, and if placed here and there in the mixed border the effect

Mixed Annual Varieties

pkt. 05

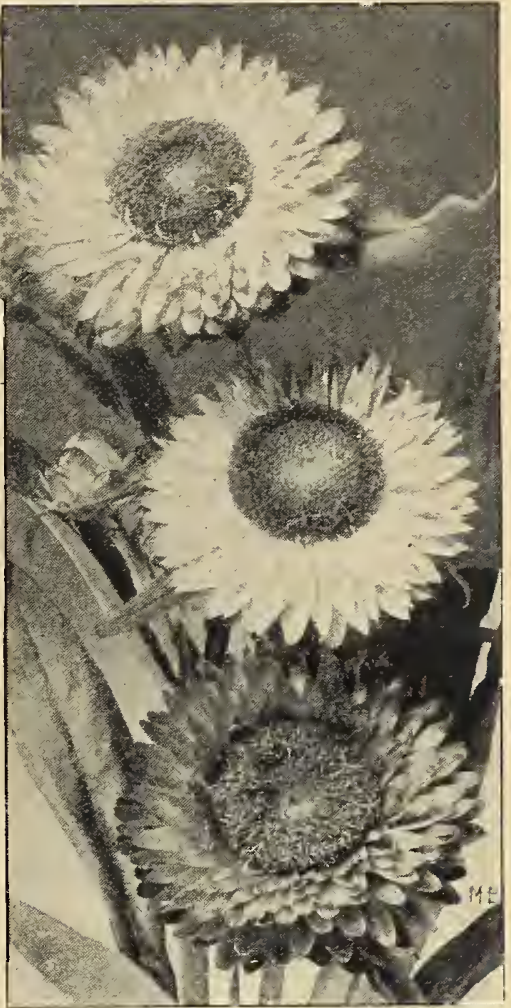

Helichrysum (Straw Flower)

\section{GOURDS Ornamental H.H.A.}

Affords a good covering for fences. The fruit of many shapes, sizes and colors, is both interesting and ornamental.

Chinese Luffa (Sponge, or Dishrag) ........\$0 05

Mock Orange............................ 03

Mixed, Many kinds

oz. 25c..

05

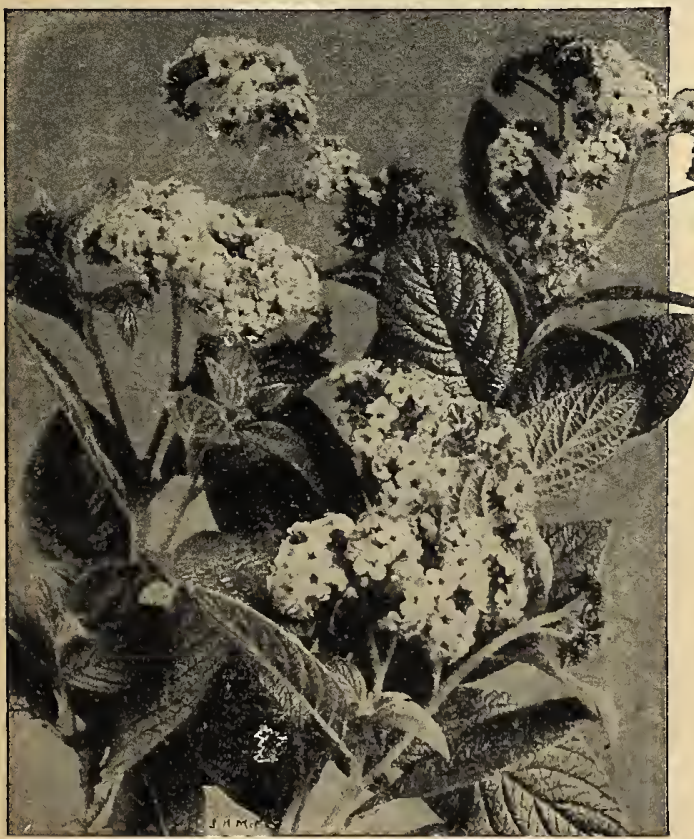

Heliotrope

\section{GYPSOPHILA (Baby's Breath)}

The pretty white, star-shaped blossoms, formed in sprays, are very showy when used in bouquets with other flowers.

Elegans alba grandiflora. Those desiring bouquet flowers should not fail Pkt. to try this variety. The small white flowers are produced in the greatest pro-

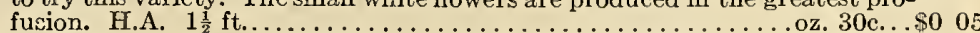

Muralis. A charming little plant for edging; flowers bright rosy pink. Annual.

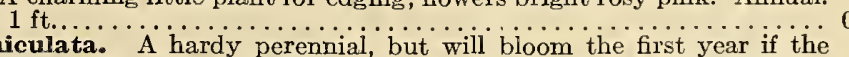
Paniculata. A hardy perennial, but will bloom the first year if the cutting. $2 \mathrm{ft} . .$. . . . . . . $\frac{1}{4} \mathrm{Oz} .15 \mathrm{c} . .$.

\section{HELICHRYSUM (Straw Flower)}

One of the favorite Everlastings. They are so easily grown, bloom so freely and continuously, that a bed or border of these pretty double annuals will afford cut-flowers all summer. Very useful for dry bouquets in winter. For early flowers sow seed indoors during March and when weather is warm in spring transplant to the garden, setting plants one foot apart. Sow outdoors in May. H.A. 1 to $2 \mathrm{ft}$.

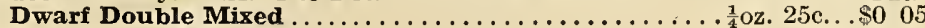

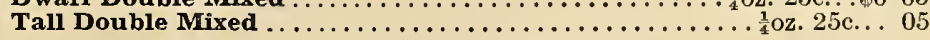

\section{HELIANTHUS (Sunflower)}

Tall, stately plants growing from 3 to 5 feet high and used mostly for backgrounds and screens. The seed should be sown outdoors in May where the plants are to remain.

New Red. A row or background of these new annual Red Sunflowers makes Pkt. a wonderfully brilliant display and from midsummer until fall they are a blaze of large, single, red and gold flowers which vary from 4 to 7 inches in

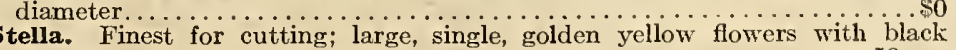
oz. $50 \mathrm{c} . . .05$

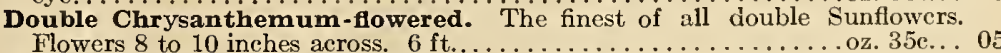

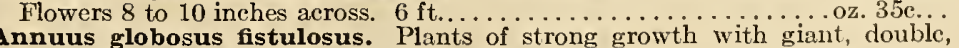
golden yellow flowers. $5 \mathrm{ft}$........ $25 \mathrm{c} \ldots .05$

HELIOTROPE. Of all the fragrant flowers, Heliotrope is as swect as any. It is a splendid garden or house plant, growing from 12 to 15 inches high, with large flower-heads and rich green foliage. Sow seed carly in March to obtain flowers the first year. H. H. P. Giant Mixed. 


M. H. BRUNJES \& SONS 篦 BROOKLYN, N. Y. W RELIABLE SEEDS

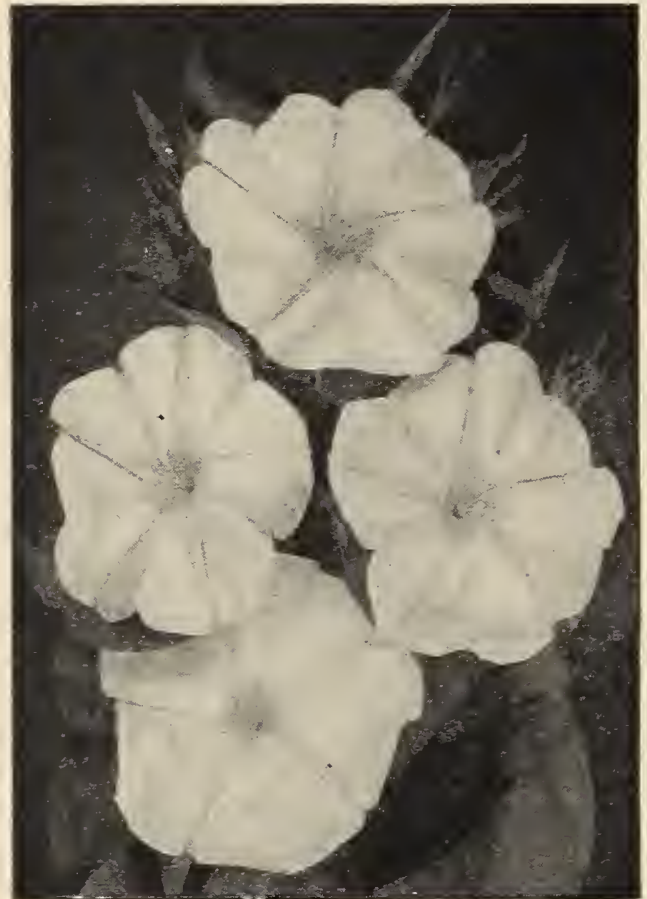

Ipomœa, Moonflower

\section{HOLLYHOCK}

Hollyhocks are the pride of the country gardens. Their stately growth, large, double flowers, many beautifully fringed and ranging in an endless variety of colors, all help to make this one of the finest perennials. Sow seed from May to. July and if possible protect plants the first year. We offer a superb strain of Chater's Double Holly. hocks. $6 \mathrm{ft}$.

\section{CHATER'S SUPERB VARIETIES}

Double Pink. varieties. Hop). Grows from 10 to 15 feet high, and its dense green foliage retains its rich color

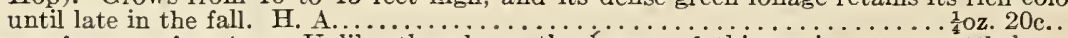
Japonicus variegatus. Unlike the above, the leaves of this variety are mottled and streaked silvery white; pretty and ornamental ................... HUNNEMANNIA fumariæfolia (Bush Eschscholtzia). Bushy plants, 2 feet high, with fern-like foliage and large, bright yellow, tulip-shaped flowers. H. A....... $\frac{1}{4}$ oz. 25c... 05 HYACINTH BEAN. See Dolichos.

ICE PLANT (Mesembryanthemum crystallinum). A dwarf, trailing annual, useful for vases and rock work. Thick ice-like foliage .

IMPATIENS. As pot plants for the house or for bedding in partly shaded places, the Impatiens are well recommended. They bloom freely, and their brilliant, colored flowers form a pretty contrast with the glossy green leaves.

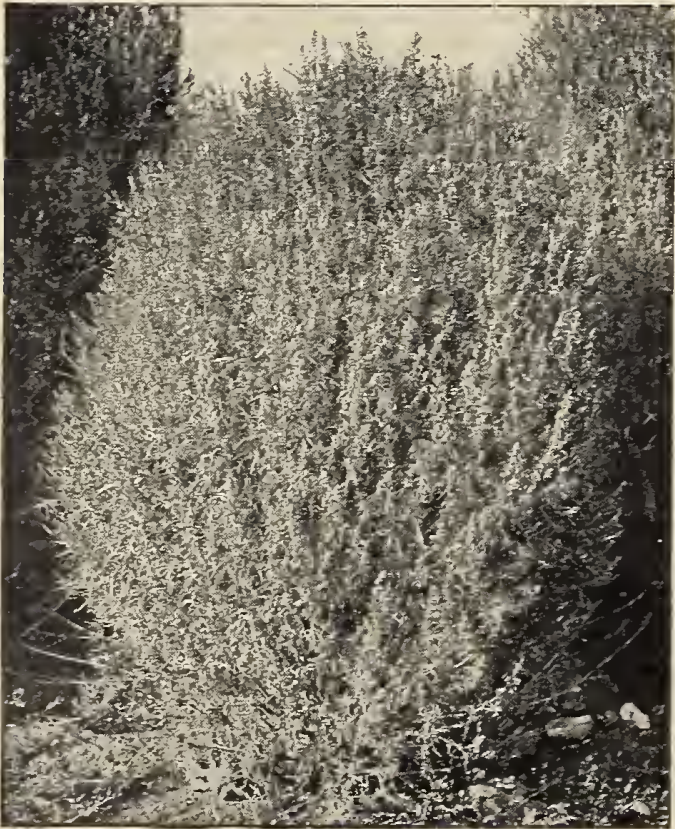

Kochia, Summer Cypress
Double Crimson

Double Purple-violet.

Double Salmon-rose..

Collection, one pkt. each of above separate colors, 50 cts.

Mammoth Allegheny. Handsome

fringed flowers, averaging 4 to 5 Pkt.

inches across. Mixed colors...... \$0 10

Double German. A fine strain. All colors, mixed........... oz. \$1...

\section{EVERBLOOMING ANNUAI HOLLYHOGKS}

The chief characteristic of this variety is that they bloom the first year, providing the seed is sown early in March. They are equally as hardy as the perennial

Double Annual Mixed. The majority are double and semi-double, but single specimens also appear. Pkt.

Single Annual Mixed.......... 05 HUMULUS Japonicus (Japanese

Sultani. Splendid variety; bright rosy scarlet. $1 \mathrm{ft}$.

Holstii. Large vermilion-scarlet flowers............ 15

Holstii Hybrids. Many beautiful colors. Splendid for summer or winter blooming... 15

\section{IPOMOEA}

As a covering for walls, porches, etc., these free-blooming, quick-growing annual climbers are unsurpassed.

Bona Nox (Evening-Glory).

Large, handsome violet-blue Pkt. flowers .............0z.25c... s0 05 Coccinea. Pretty scarlet; starshaped blossoms; dense foliage..

Grandiflora alba (Moonflower).

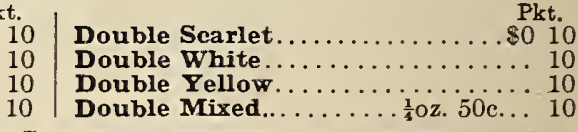

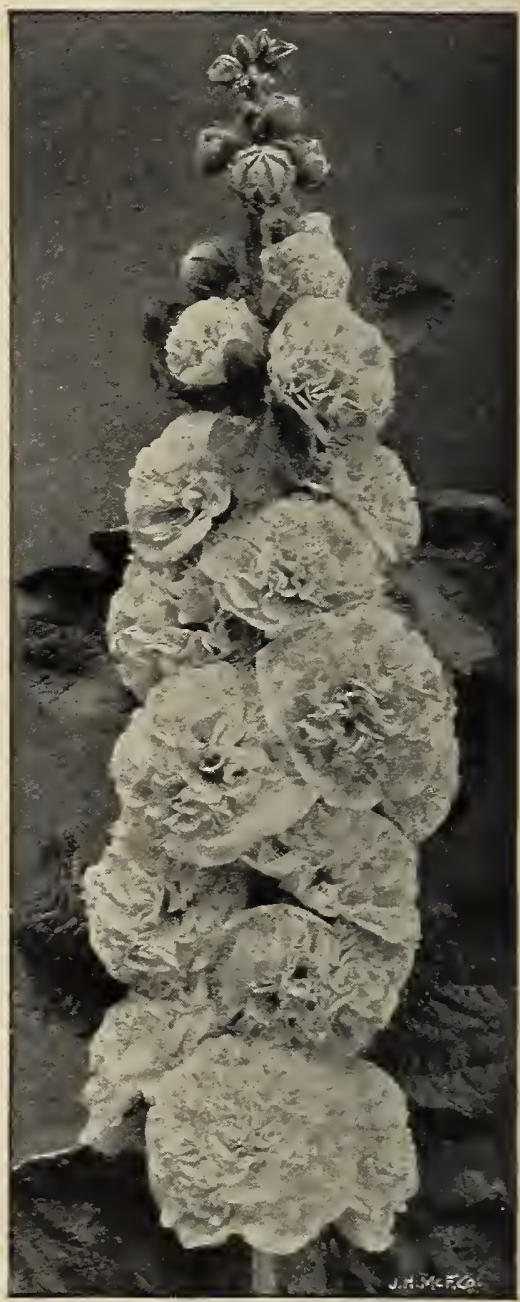

Hollyhock, Chater's Double
One of the finest and quickest growing climbers. It has beautiful heart-

shaped leaves and hundreds of immense pure white, fragrant flowers, Pkt. which open in the evening and on cloudy days. 15 to $20 \mathrm{ft} . \ldots, \frac{1}{4} \mathrm{oz} .25 \mathrm{c} . . \$ 010$

Rubro cœrulea (Heavenly Blue). The flowers are borne in clusters and of a lovely sky-blue color.

Finest Mixed. Oz. $25 c \ldots 05$

JACOB AEA elegans fi. pl. Very pretty annual, about $1 \frac{1}{2}$ feet high, continuing in bloom until frost. Mixed Colors.

KOCHIA tricophylla (Summer Cypress). An ornamental annual with cypress-like foliage. During the summer the plants are light green, but turn to a rich carmine in fall, at which time they are also covered with small, bright scarlet flowers, giving the plants an appearance similar to a

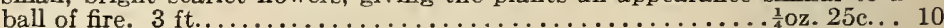

LANTANA hybrida nana compacta. Shrubby plants with beautiful heads of verbena-like flowers, valuable alike for the garden or house. H. H. A. 05 


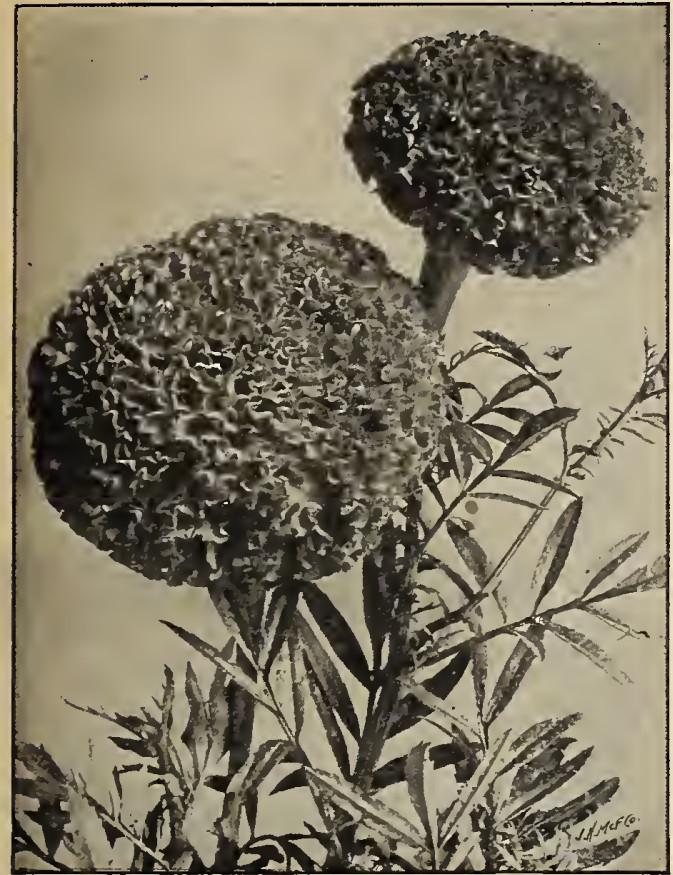

Marigold, African, Orange Prince (see page 44)

\section{LARKSPUR}

A favorite German flower appearing in many colors, as white, pink, rose and all shades of blue. Very effective when grown in clumps, and the taller sorts are fine for cutting. Sow outdoors early in spring.

\section{DOURLE STOCK- FLOWERED}

Superb for cutting. 2 to 3 feet.

Pkt.

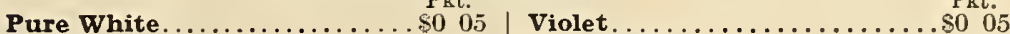

Pkt.

Bright Rose.............. 05 Finest Mixed ........... 40... 05

Double Dwarf Rocket. $1 \mathrm{ft}$. Finest Mixed.................... 05

Tall Rocket. Splendid variety; long spikes of double flowers. $2 \mathrm{ft} . \ldots \ldots \ldots \ldots 05$

Emperor. A large-flowered, free-blooming Larkspur. Mixed Colors......... 05

LINARIA Cymbalaria (Kenilworth Ivy). Dwarf trailing plant for hanging baskets, rockwork, etc. Lavender and purple flowers............ 10

LINUM grandiflorum rubrum (Scarlet Flax). Effective, free-flowering plants. Brilliant crimson-scarlet flowers. $1 \mathrm{ft} . \ldots \ldots \ldots \ldots \ldots \ldots$........... 05

Flavum. Beautiful golden yellow perennial.................... 10

Perenne (Blue Flax). Bright blue. H. P. $1 \frac{1}{2} \mathrm{ft} . \ldots \ldots \ldots \ldots \ldots \ldots \ldots . \ldots \ldots$

\section{LOBELIA}

Neat little plants so much admired when used for edging, bedding or rockwork. Though but 6 inches high, they are in constant bloom all summer and in a slightly shaded position remain so until fall. H. H. A.

\section{TRAILING VARIETIES}

Gracilis. Light blue. Pretty for vases and hanging baskets; trailing........ \$ $\$ 05$ Speciosa. Best dark blue trailing Lobelia.

\section{GOMPACT BEDDING VARIETIES}

Emperor William. Sky-blue flowers; compact plant, splendid for edging Crystal Palace compacta. Strikingly beautiful; superior dark blue bedding Lobelia..................................... . . . . . . . 50c... Pumila splendens (Bedding Queen). Dwarf and compact; flowers rich purpleblue, with clear white eye

white Gem. Finest pure white for bedding.

Finest Mixed. Only the dwarf, compact varieties. LOPHOSPERMUM scandens. A tender annual climber, having dark rosecolored, trumpet-shaped flowers. $10 \mathrm{ft}$.

05

10
10 10 10 10 10

\section{LUPINUS}

The annual Lupines form nice plants for bedding, while the tall-growing perennial sorts are very attractive when used as a background or border. All are showy, freeflowering and have long spikes of pea-shaped flowers.

Annual Mixed, All Colors. $2 \mathrm{ft}$.

Polyphyllus roseus. Invaluable for cutting. Handsome spikes of rose-colored flowers. Blooms in May and June. H. P.

Polyphyllus, Mixed. Perennial varieties. $4 \mathrm{ft}$.

oz. $25 \mathrm{c} . . \$ 005$

L YCHNIS chalcedonica. Hardy perennial of striking appearance, with brilliant scarlet flowers. $2 \mathrm{ft}$..

Chalcedonica, Mixed. Scarlet and white.

Haageana. A desirable plant for the hardy border. Single flowers of deepest

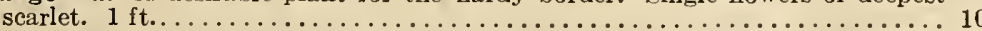

MALOPE grandiflora purpurea. Hardy annual, bearing mallow-like flowers of a deep red color from July until frost. $2 \mathrm{ft}$. .

MATRICARIA (Feverfew). A half-hardy perennial which blooms the first year from seed. The small, very double white and yellow flowcrs are produced in the greatest profusion all summer. Seed may be sown in May, but better still, during March indoors.

Capensis fl. pl. The finest white variety for cutting. $1 \frac{1}{2} \mathrm{ft}$..

Tom Thumb, Double White. This dwarf-growing Feverfow is splendid for bedding, edging or pot culture. $1 \mathrm{ft}$

Golden Ball. A bed or border of this charming variety with its countless numbers of small, double, golden ycllow flowers makes one of the most beautiful sights all summer. $1 \mathrm{ft}$.

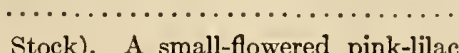

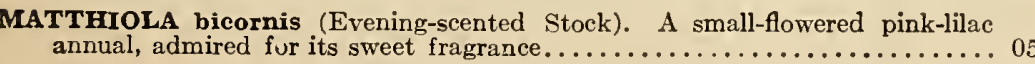

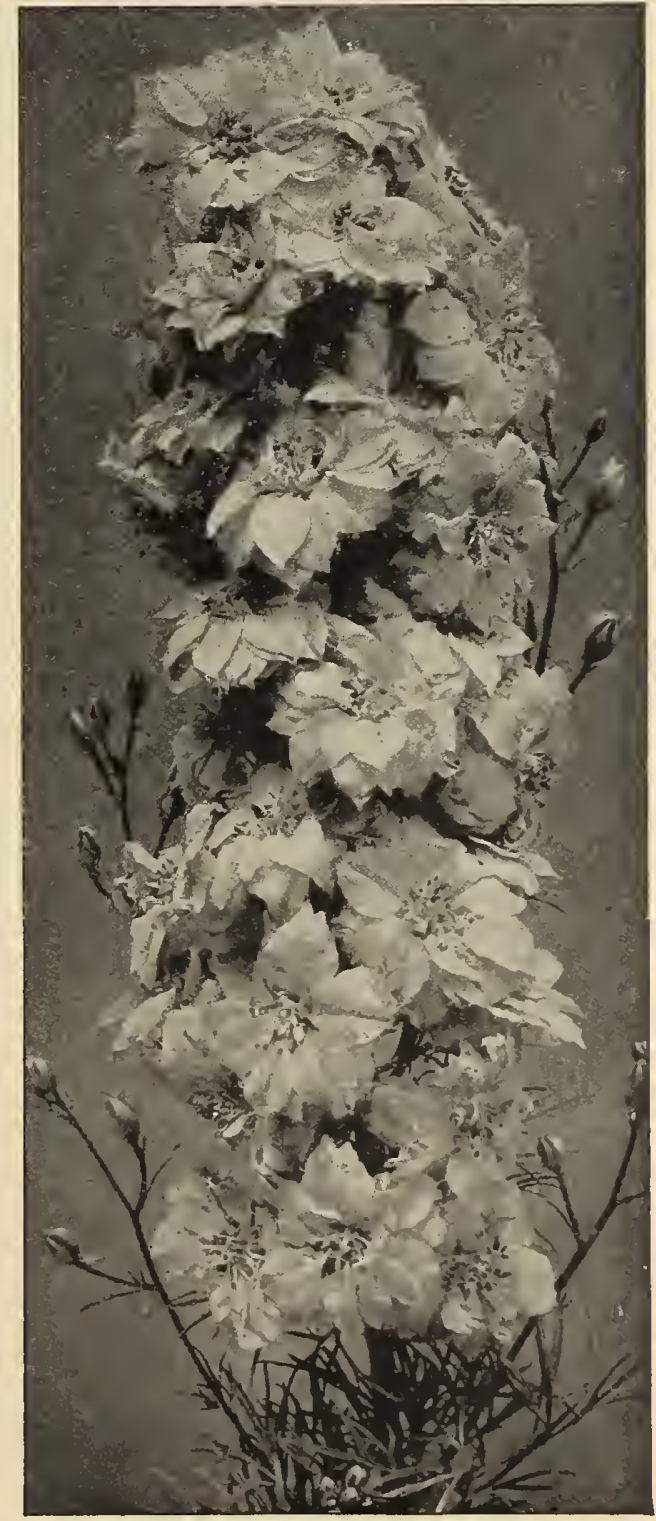

Larkspur, Double Stock-Flowered 


\section{MARIGOLD}

The Marigold shows its full value toward fall, when most bedding plants are usually past their best. Many prefer the African varieties, with their extra-large, double yellow and orange flowers, but the dwarf, smaller-flowered French sorts, with their handsome spotted and striped flowers, are justly popular and equally beautiful. H.H.A.

\section{DOUBLE AFRIGAN MARIGOLDS}

Lemon Queen. Of immense size, densely double and clear Pkt lemon color. $3 \mathrm{ft} . \ldots \ldots \ldots \ldots \ldots \ldots \ldots \ldots \ldots{ }_{4}^{1} \mathrm{oz} .40 \mathrm{c} . . \$ 0 \quad 10$ Orange Prince. A mate to Lemon Queen, with rich, orange-

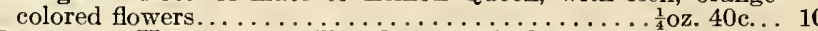

Eldorado. Handsome, quilled flowers 3 inches or more in diameter, and ranging in various tints of yellow and orange. One of the finest; extremely double. $3 \mathrm{ft} \ldots \ldots \ldots \ldots \ldots \ldots \frac{1}{4} \mathrm{oz} .40 \mathrm{c} .$. Tall Double Mixed...

Dwarf Double Mixed. 18 inches oz. $60 \mathrm{c}$. oz. $60 \mathrm{c}$.

\section{DWARF FRENGH MARIGOLDS}

Dwarf Dark Brown. One of the finest for bedding; rich velvety color.

Dwarf Orange. Splendid for borders.

Dwarf Gold-Striped. A favorite and very effective variety; fine for pots. $1 \mathrm{ft}$

Legion of Honor ("Little Brownie"). This charming singleflowered Marigold is a mass of flowers all summer. Yellow with reddish brown spot.

oz. $60 \mathrm{c}$. .

Dwarf Double Mixed.

MARVEL OF PERU (Four-o'Clock). Well-known hardy annuals. The bushes grow 2 to 3 feet high and produce often 100 or more flowers on a single plant.

Finest Mixed. All colors.

oz. $20 \mathrm{c}$.

\section{MIGNONETTE (Reseda)}

The Mignonette is universally admired for its delicate perfume and singularly pretty spikes of bloom. Liberal sowings from April to July will afford a continuous supply of this favorite flower, so

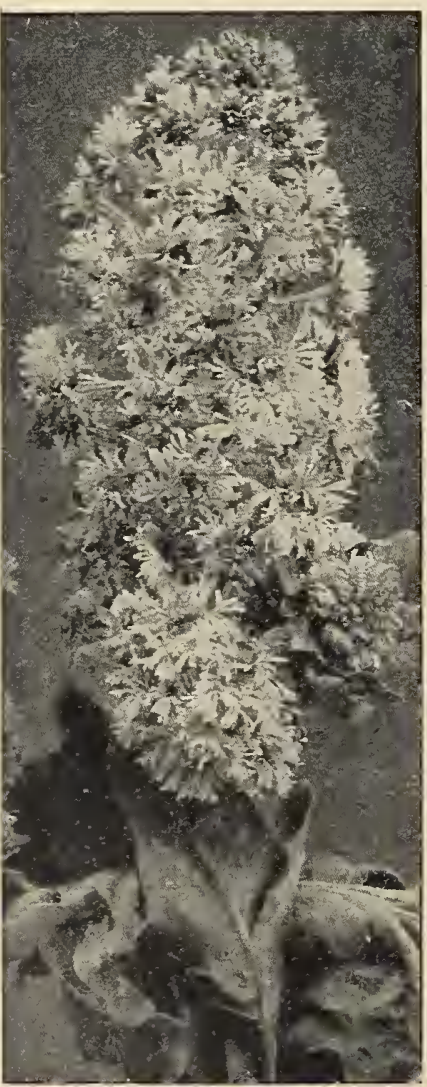

Mignonette Machet largely used and so much admired for bouquets. Mignonette succeeds best if sown where the plants are to bloom. H.A. Pkt.

Goliath. An excellent popular annual with very large trusses of fire-red flowers; plants of strong and robust growth. Fine for forcing and garden culture............\$0 1

Machet. One of the very ist or private gardens. Dwarf, compact plants and large, thick spikes of deliciously fragrant flowers. Our strain is fine. $\frac{1}{4} \mathrm{Oz} .25 \mathrm{c} . .10$

Allen's Defiance. Splendid for cutting. The long spikes are thickly studded with sweet-scented flowers........... $\frac{1}{4} \mathrm{oz} .25 \mathrm{c} . . .10$ Ruby. " A large-flowering Machet Mignonette with coppery scarlet flowers... 10

Golden Queen. A distinct variety; golden yellow.

Large-flowering Sweetscented......oz. $20 \mathrm{c}$. . 05 MIMULUS tigrinus (Monkey Flower). Dwarfgrowing plants, with very showy, spotted, and tigered flowers.... 05 Moschatus (Musk Plant). A free-blooming, small, yellow-flowered variety suitable for hangingpots and vases. Blooms the first year from seed sown in March. $\frac{1}{2} \mathrm{ft}$.

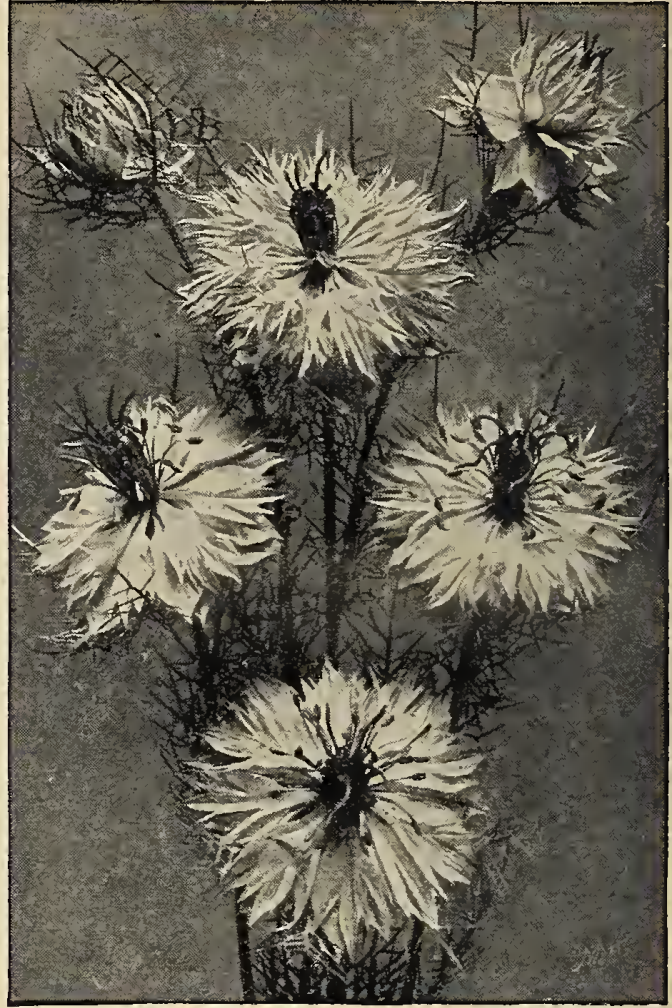

Nigella, Miss Jekyli (see page 45)

MOMORDICA. Well-known annual climbers grown largely Pkt. for their fruit which is used for medicinal purposes. $10 \mathrm{ft}$.

Balsamina (Balsam Apple). Orange fruit...... oz. 40c.. \$0 05

Charantia (Balsam Pear). Copper-colored scarlet fruit...... 05

MOONFLOWER. See Ipomœa.

MORNING-GLORY. See Convolvulus. MOURNING BRIDE. See Scabiosa.

\section{MYOSO'TIS (Forset-Me-Not)}

The Forget-me-not is one of the most cheerful of our springblooming plants. A bed or border of the blue-flowered (Victoria) variety is very pretty and when in full bloom the plants which grow hardly 6 inches high are almost hidden by flowers. From seed sown in August, blooming plants may be had the following May, or if sown early in spring, blooms the first year. Protect over winter. H.H.P.

Alpestris, Blue. The common blue variety ........oz. 75c.. \$ $\$ 005$ Alpestris, Victoria. The favorite bright blue variety for bedding and pot culture. Dwarf, compact plants. 6 inches... $\frac{1}{4}$ oz. 50c... 10 Alpestris, Mixed. Blue, white, and pink.......... oz. 75c... 05 Ruth Fischer. The largest-flowering of all. The exquisite coloring of the flowers, true Forget-me-not-blue, and glossy dark green foliage form a charming contrast. Excellent for pots and

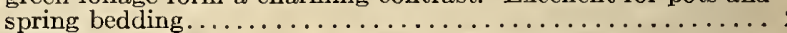

Triumph. An early, large-flowering Forget-me-not, blooming in two months after sowing. Flowers blue, with yellow eye.... 10

NEMESIA strumosa grandiflora. This very free-flowering annual, if started indoors in March and April, will make fine plants for spring bedding. The bright showy flowers of yellow, orange, crimson, and rose are produced in endless profusion on plants 12 to 15 inches high. Mixed colors............. 10

NEMOPHILA. A hardy annual growing about 1 foot high, with small, cup-shaped, blue, white, and spotted flowers. They do best if sown in rather poor soil, and a partially shaded position. Seed should be sown where plants are to bloom, as they do not stand transplanting.

Insignis. Flowers bright blue with white centers...oz. 25c.. 05 Insignis alba. Clear snow-white flowers......... oz. 25c... 05

Fipest Mixed. All colors.................. oz. 25c... 05 
While Sweet Peas have always been very popular, it has been the introduction of the Spencer type that has caused them to be the most talked-about flower at the present time. The vines are of strong, vigorous growth, surpassing the standard sorts in this respect. The wonderfully large, fragrant flowers, measuring up to 2 inches across, are gracefully formed, on long stout stems, each bearing three and of ten four blossoms. For cutting, vase decoration and exhibiting, the Sweet Pea stands supreme, and every garden, whether large or small, should contain some of the new Spencers this year.

Culture.-A deep, rich and rather moist soil is best adapted to growing Sweet Peas. A place at least 1 foot wide and not less than a foot deep should be thoroughly spaded, and a liberal amount of manure or bone meal added. Very early in spring, preferably in March or April, after digging a trench 5 to 6 inches deep, sow the seed 1 inch deep and sow thinly. When 3 to 4 inches high, thin out the plants to $\delta$ inches apart and gradually fill in the trench with soil. A trellis or brush should be provided for their support. Pick flowers frequently, otherwise the plants will soon stop flowering.

Asta Ohn. A superb pinkish lavender Spencer; usually four flowers on a stem.

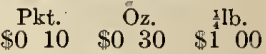

Blue Picotee. A large, perfectly formed flower almost pure white in color except for a narrow edging of violet-blue. .

Blanche Ferry Spencer. The favorite pink and white variety with immense wavy flowers;

$\begin{array}{llll}10 & 30 & 1 & 00\end{array}$
splendid for cutting............

Countess Spencer. One of the best; bright clear pink, shading deeper at the edges; strong grower..................

Dainty Spencer. Fine long stems, each bearing four immense wavy flowers; pure white, edged rosepink....................

Dobbies Cream. The best primrose Spencer variety. Flowers of large size, perfect form and lovely cream color...............

Elfrida Pearson. A splendid variety in every way. Free blooming, vigorous grower and produces. strong stems which usually carry four blossoms. The finest and largest blush-pink...

Helen Lewis (Orange Countess). A magnificent, giant-flowered orange-pink..........

John Ingman (George Herbert). Rosy carmine showing veins of a deeper shade..

King Edward Spencer. A splendid variety; rich crimson-scarlet.................

Marguerite Atlee. A giant apricot-pink on cream ground. A most useful Pea for exhibition or garden decoration...........

Othello Spencer. The flowers of this handsome variety are deep maroon, a dark, very striking and most effective color..........

Royal Purple. One of the finest and most distinct varieties which should be in every collection. The flowers of rich royal purple are pro-

duced abundantly $\ldots \ldots \ldots \ldots \ldots \ldots \ldots \ldots \ldots \ldots \ldots \ldots$
Senator Spencer. A grand introduction; admired for its rich and beautiful colors. Striped deep claret and chocolate on a light heliotrope ground. Extra-large flowers, beautifully waved and splendid in effect.....

White Spencer. The flowers, of enormous size and purest white, are produced on long, strong stems......

10

100

$10 \quad 30 \quad 100$

10

10

$30 \quad 100$

10

$30 \quad 100$

10

$30 \quad 100$

10

30

100

10

100

10

$30 \quad 100$

10

Collection, one pkt. each of the above 15 Giant Spencer Sweet Peas, $\$ 1$.

\section{Mixtures of Sweet Peas}

Brunjes' Giant Spencer Mixed A space in every flower-garden phontin be reserved for a liberal planting of this grand mixture. It is composed entirely of the Giant Spencers,
the largest and most beautiful of all Sweet Peas, and we feel confident that our customers will be more than pleased with the results obtained from this superb mixture. Pkt. 10 cts., oz. 20 cts., $\frac{1}{4}$ lb. 60 cts., lb. $\$ 2.25$.

Brunjes' Large-flowering Mixed. Special care has been taken in selecting the different varieties for this mixture and only the best of the standard sorts have been used. Pkt. 5 cts., oz. 10 cts., $\frac{1}{4} \mathrm{lb}$. 30 cts., lb. $\$ 1$.

\section{Perennial Peas (Lathyrus latifolius)}

A hardy climber with large clusters of red, white and pink blossoms. Fine for cutting. H.P. $8 \mathrm{ft}$. Finest mixed, pkt. $5 \mathrm{cts}$, $0 z .40 \mathrm{cts}$. 


\section{H. BRUNJES \& SONS Br.}

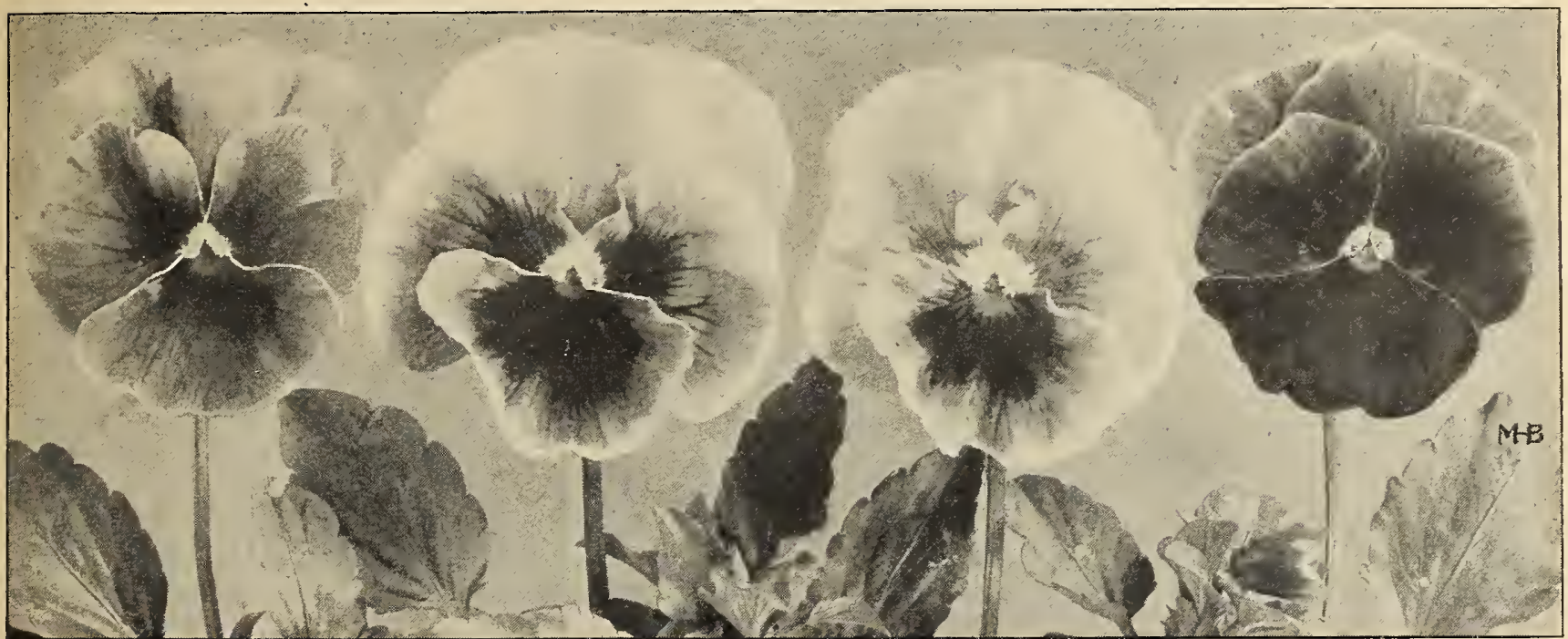

Brunjes' Giant Beauty Pansies

\section{PANSIES}

The Pansy has become one of our most popular plants for bedding and may be seen in bloom almost the year round, but it is during May they appear at their best. To have them bloom in May, the seed should be sown during July or August, so that it may develop into strong plants for remaining outdoors over winter, with a slight protection. For later flowers sow seed in early spring.

\section{GHOICE MIXTURES OF PANSIES}

Brunjes' Giant Beauties. A superior mixture containing for their richness of color, perfect form, and immense-sized blooms. Especially recommended for either early spring or late summer sowing. Pkt. 25 cts., $\frac{1}{8} \mathrm{oz}$. $\$ 1$.

MASTERPIECE, One of the larger-flowering Pansies; distinct from all others, in that the petals are beautifully frilled or ruffed, giving the flowers an unique, though very fascinating appearance. In color, they range chiefly through the darker shades. Pkt. 20 cts., $\frac{1}{8} \mathrm{Oz} .75 \mathrm{cts}$.
GIANT PARISIAN. Somewhat lighter colored than the Giant Trimardeau and particularly recommended to those desiring a bright, showy mixture. Flowers mostly five-lobed. Pkt. $15 \mathrm{cts} ., \frac{1}{4} \mathrm{oz} . \$ 1$. GIANT TRIMARDEAU. Plants of this type are of strong, compact growth, free bloomers, and withstand unfavorable weather remarkably well. Flowers are of largest size, usually stained or blotched, and in an endless range of colors. Pkt. $10 \mathrm{cts.}$, oz. $\$ 3$.

MME. PERRET. The flowers of this variety are mainly of the red, rose and wine shades, edged white............pkt. 10c.

FINE MIXED. All colors.....................

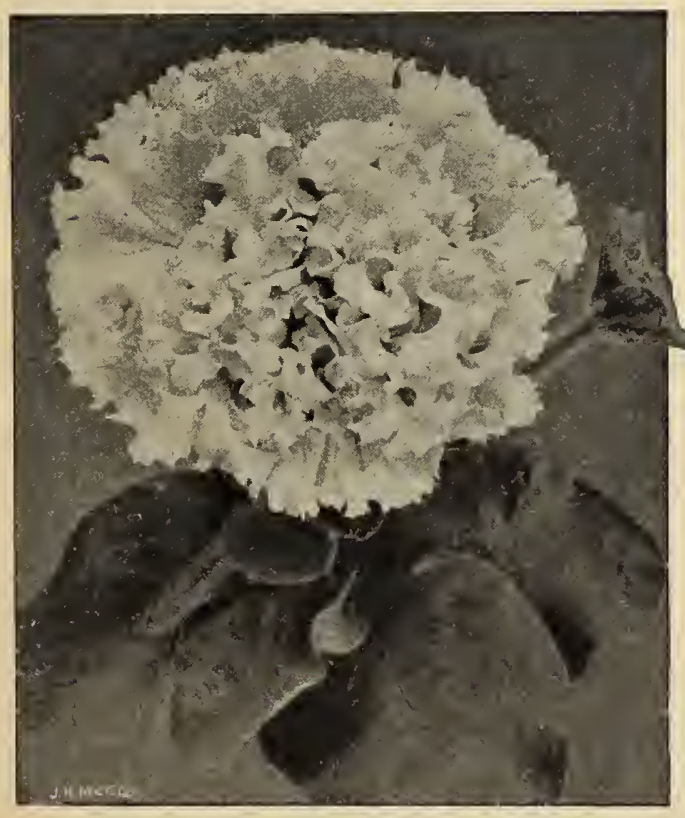

Petunia, Double Large-flowering Fringed

\section{GIANT SEPARATE GOLORS OF PANSIES} GIANT BLUE. Bright cornflower-blue, with dark eye ........ $\frac{1}{4}$ oz. $\$ 1 \ldots \$ 0$ Pkt. GIANT GOLDEN QUEEN. Pure yellow.................... GIANT GOLDEN YELLOW. Center stained with black; large and very showy. 10 Giant Lord Beaconsfield. Rich, vclvety purple-violet, the upper white. Very popular and unsurpassed for bedding........... Giant Mercury. The flowers are of enormous size, well formed and of a

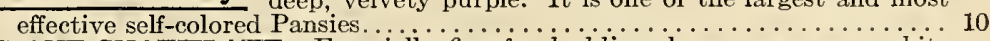
GIANT SNOWFLAKE. Especially fine for bedding; large, pure snow-white

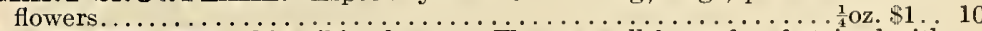
GIANT STRIPED. Of striking beauty. Flowers well formed and striped with 10 pretty colors..... STAined PURPLE. An excedingly attractive variety of

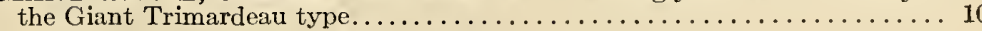

\section{TUFTED PANSIES (Viola cornuta)}

Although the flowers are somewhat smaller than the more popular Pansies, this class of Violas produces its blossoms in greater abundance and remains in bloom until early fall. From seed sown in April blooming plants may be had in June.

Choice Mixed. Many handsome colors

PENTSTEMON Hartwegii, Mixed. Very effective plants, growing 2 feet

high, with long spikes of brilliant, richly colored flowers, many beautifully spottcd. Seed sown early in March in the housc will produce blooning plants the first year.

PHYSALIS Franchetii (Chinese Lantern Plant). A hardy perennial, about 2 feet high, blooming the first year from sced and admircd for its brightcolored seed-pods, which are at first golden yellow but later change to orange-scarlet. The pods are quite similar in appearance to snall lanterns. . 05 


\begin{tabular}{|c|c|c|}
\hline M. H. BRUNJES \& SONS & BROOKLYN, N. Y. & RELIABLE SEEDS \\
\hline
\end{tabular}

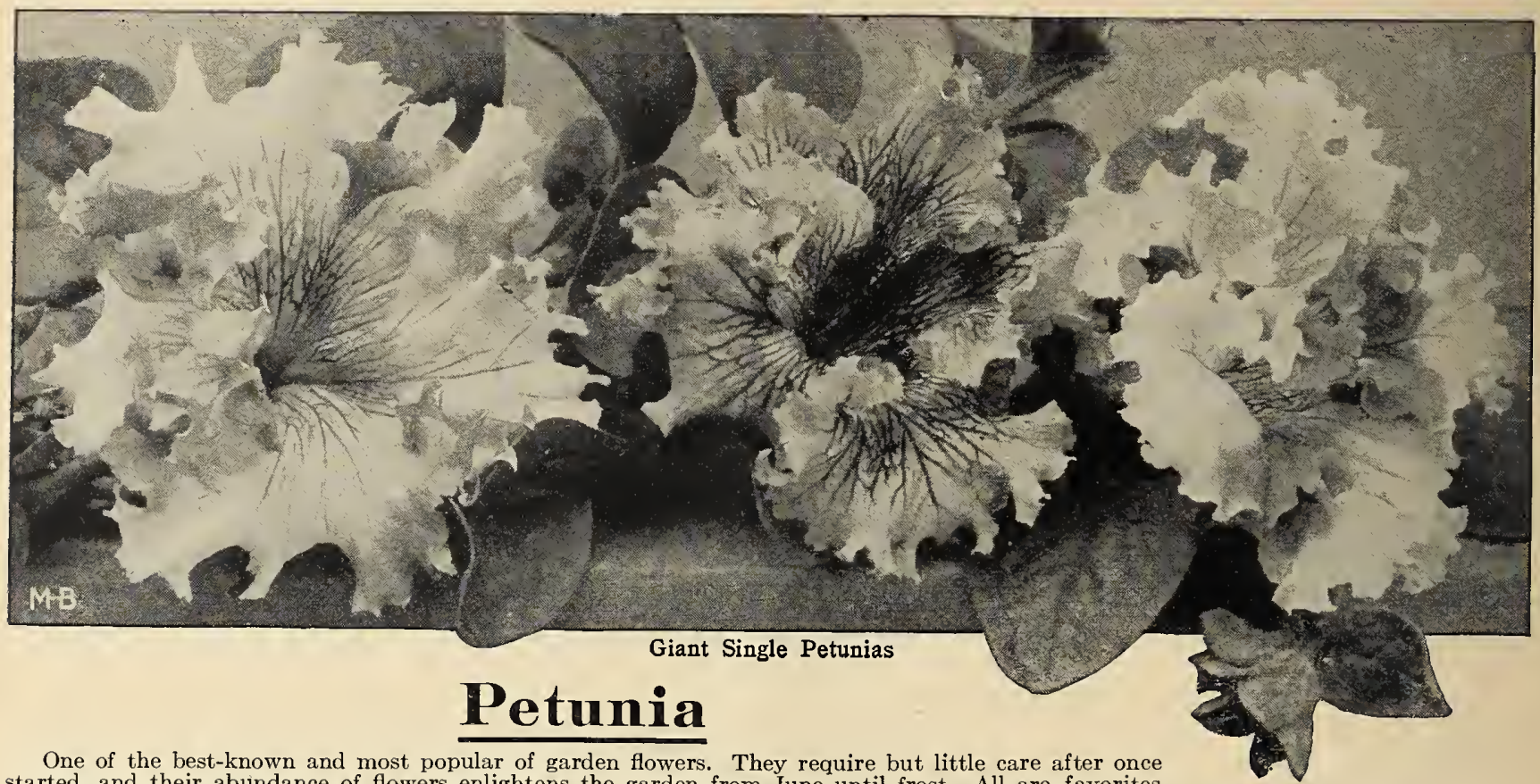

started, and their abundance of flowers enlightens the garden from June until frost. All are favorites,

and whether for bedding, borders or massing, they have few superiors. The bedding varieties may be sown outdoors in May, but the

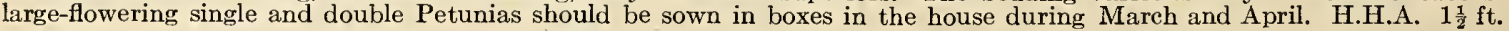

\section{Sinǵle Large-flowering Petunias} Brunjes' Giant Prize Mixed. You cannot help butad- Pkt. Petunias, and this Prize strain is the giant-flowering The flowers are of enormous size, of ten measuring 5 inches across, while the colors are most beautiful, some soft and delicate, others rich and gorgeous, and all an object of great beauty. One packet of seed will produce sufficient plants for a good-sized bed .$\$ 025$

Giants of California. Splendid large-flowering strain, with handsome fringed and ruffled flowers. The colors range from the purest white to pink, carmine, crimson, and maroon; beautifully

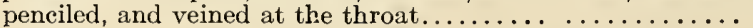

\section{Poppies}

One of the prettiest old-fashioned annuals with large double or single flowers of almost every color imaginable, blooming profusely during the summer months. A light, sandy soil is best suited for their culture. The seed germinates quickly and should be sown outdoors very early in spring, where the plants are to bloom. See that plants are thinned out to 8 inches apart.

Santa Rosa Shirley. A superior strain of the grand Shirley Poppy, which is Pkt. noted for its beautiful colors and extra-large flowers.......... Admiral. A bed or border of this large, single-flowered variety is very striking. Its flowers are of purest white with a broad band of brilliant scarlet at the top.. 05 Tulip-Poppy (Glaucium). The brightest of all; dazzling scarlet tulip-like flowers. $1 \mathrm{ft} .10$ Single Finest Mixed. A bright, showy mixture $\ldots . . . \cdots \cdots . . .02 .25 \mathrm{c} . .05$ Double Carnation-flowered. The large, ball-shaped flowers are deeply cut and fringed, very double, and appear in many different colors, including both the solid and striped varieties, $2 \mathrm{ft}$. Finest Mixed

Double Peony-flowered. One of the best double sorts, having immense, peonyshaped flowers, often measuring 4 to 5 in. across. $2 \mathrm{ft}$. Finest Mixed. . oz. 35c... 05

\section{Hardy Perennial Poppies}

Every hardy border should have some of these stately perennial Poppies. They are perfectly hardy and after once planted will take care of themselves, increasing in size and beauty year after year. Seed may be sown in the spring, and although the plants disappear during the hot summer months they reappear in the fall and should then be transplanted to permanent positions. Seed can also be sown in the early fall. Pkt. Bracteatum. Large, single, crimson-scarlct flowers. $3 \mathrm{ft} . \ldots \ldots \ldots \ldots \ldots . \$ 05$ Orientale. Affords a most effective display during June and July. Flowers measure 5 to 6 inches across: dark red with black spot on each petal. $3 \mathrm{ft}$

Orientale Hybrids. Exceedingly large, single flowers with various shades of rose,

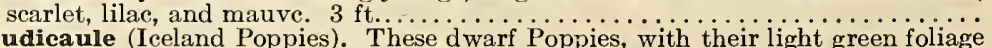
10 and fragrant flowers, bloom the first year from seed. $1 \mathrm{ft}$. Single Mixed...... 10

05

05

\section{Single Bedding Petunias}

\footnotetext{
5

5
}

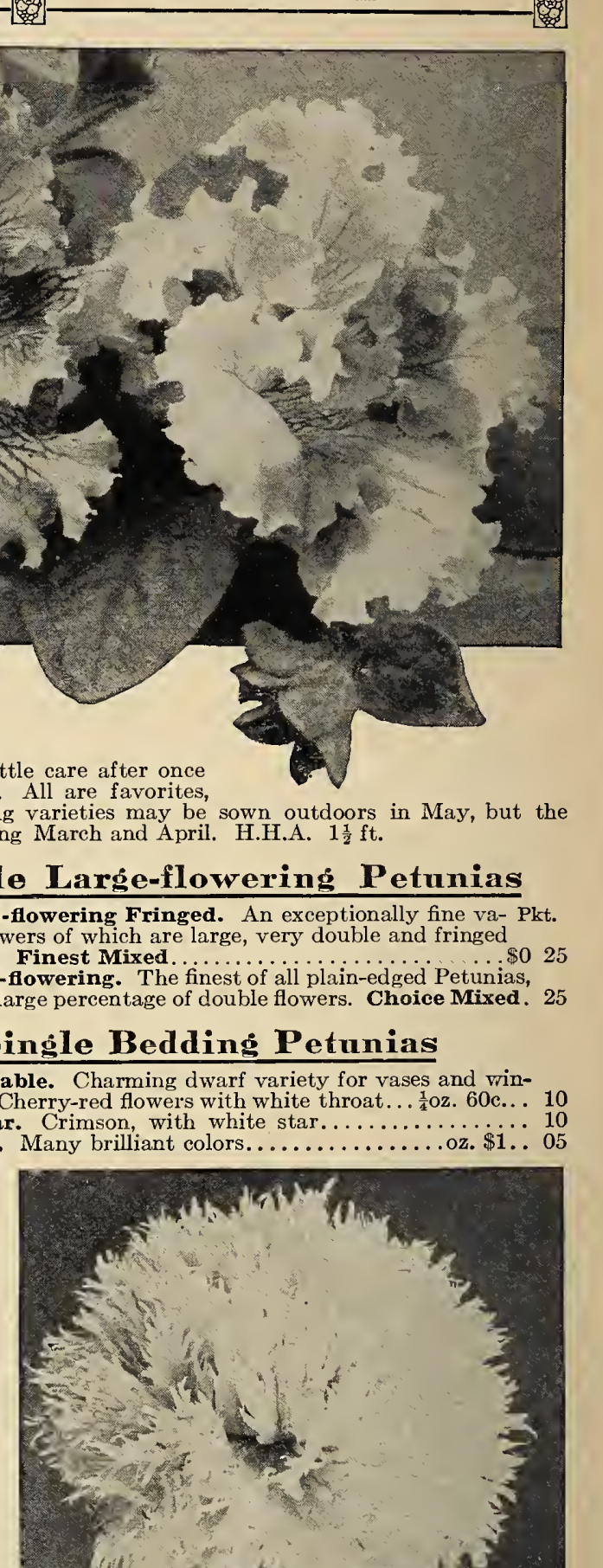




\begin{tabular}{|c|c|c|}
\hline M. H. BRUNJES \& SONS & BROOKLYN, N. Y. & RELIABLE SEEDS \\
\hline
\end{tabular}

\section{Phlox Drummondi}

This hardy annual, with its bright showy flowers, can not be too highly recommended for bedding purposes or ribbon borders, as the plants remain in bloom until late in summer. The Grandiflora variety, if planted in rich soil, attains a height of 12 to 15 inches and affords splendid spikes of flowers for eutting.

\section{GRA NDIFLORA VARIETIES}

Alba. Splendid pure white flowers ............\$0 10

Atropurpurea. Deep purple................... 10

Crimson. Rich, dazzling color

Rosea. Soft rosy pink.

Scarlet. Bright and showy

Striped. Many pretty colors

Grandiflora. Finest mixed.

\section{NANA GOMPACTA PHLOX}

Superior bedding plants, of neat, compact habit, growing but 6 inches high and often a foot in diameter, with large heads of brilliant-colored flowers.

Defiance. Very bright scarlet.

Fireball. Handsome dark red.

Hortensiæeflora. Rose..

Snowball. Pure white.

Splendens. Crimson, white eye

Nana compaeta. Finest mixed

CECH Y PHL OX. A dwarf, large-fowe... ${ }_{4}^{4} \mathrm{oz} .60 \mathrm{c} . .10$

the Phlox nana compacta la

of colors. $\frac{1}{2} \mathrm{ft}$. Choice Mixed.

Star of Quedlinburgh. Pretty star-shaped flowers. Finest Mixed.

Decussata. Hardy perennials, bearing large trusses of

bright-colored flowers. $2 \mathrm{ft}$. Finest Mixed.

PLATYCODON. See Wahlenbergia.

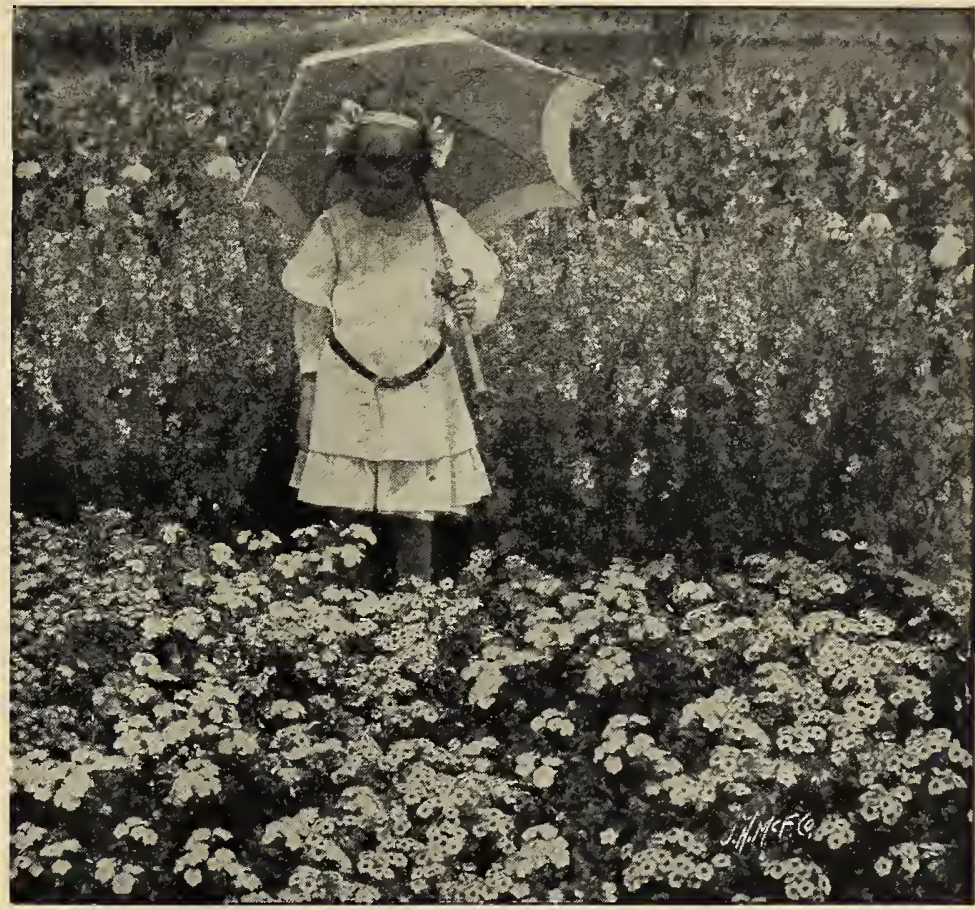

Phlox Drummondi nana compacta

\section{Primula (Chinese Primrose)}

The Chinese Primrose is one of the favorite pot-plants for winter blooming, either in the house or conservatory. The fringed, richcolored flowers of very large size and handsome appearance, are in constant bloom throughout the greater part of the winter. Sow the seed from April until June. 9 inches.

Chinensis fimbriata, Giant-Flowered Fringed. A magnificent strain for exhibiting. The flowers of gigantic size, finest form and most exquisite colors, are thrown well above the Pkt: foliage. Mixed.

Chinensis fumbriata, Finest Fringed Mixed.

Chinensis stellata (Star Primrose). Very pretty, free-blooming

plants for decorative purposes, with graceful spikes of star-

shaped flowers borne well above the foliage

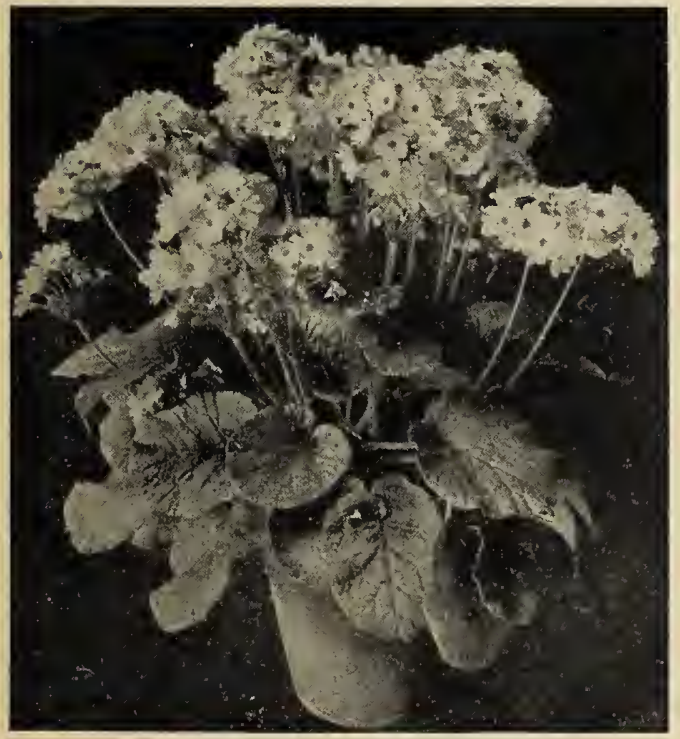

Primula obconica grandiflora

Obconica grandifiora. Splendid free-blooming hybrids, bear- Pkt. ing large clusters of flowers three months after sowing. $1 \mathrm{ft}$.

Fine Mixed Hybrids.

$\$ 0 \quad 10$

Obconica gigantea. An improved strain of the above, with extra-large flowers and comprising many beautiful shades and colors.

Kewensis. A new and charming acquisition to the Primula fam25 ily, making very fine house plants for winter blooming. The bright yellow flowers are fragrant and produced in whorls along the full length of the stem, which adds to their beauty and attractiveness. Sow seed early in spring. 18 inches

\section{HARDY PRIMROSES}

Auricula. This half-hardy perennial blooms profusely early in spring, affording a splendid display of richly marked flowers. Choice Mixed. Pkt. 10 cts.

Elatior (Polyanthus).

These well-known perennials are not perfectly hardy, but if protected in a coldframe during the winter, make excellent bedding plants for spring blooming. The beautiful, various - colored flowers are marked in the most striking manner and succeed best in partial shade. $1 \mathrm{ft}$.

Finest Mixed. Pkt. 10 cts.

Gold Laced. Pretty bright-colored flowers. Pkt. $10 \mathrm{cts}$.

Vulgaris (English Primrose). Yellow; fragrant. Pkt. 10 cts.

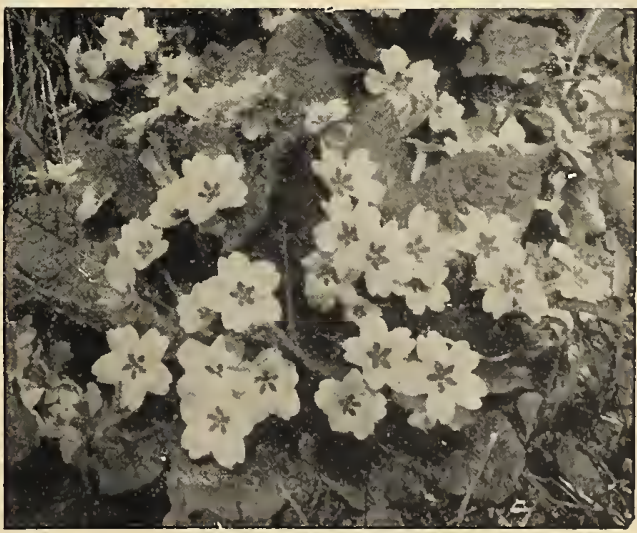

Primula elatior (Polyanthus) 


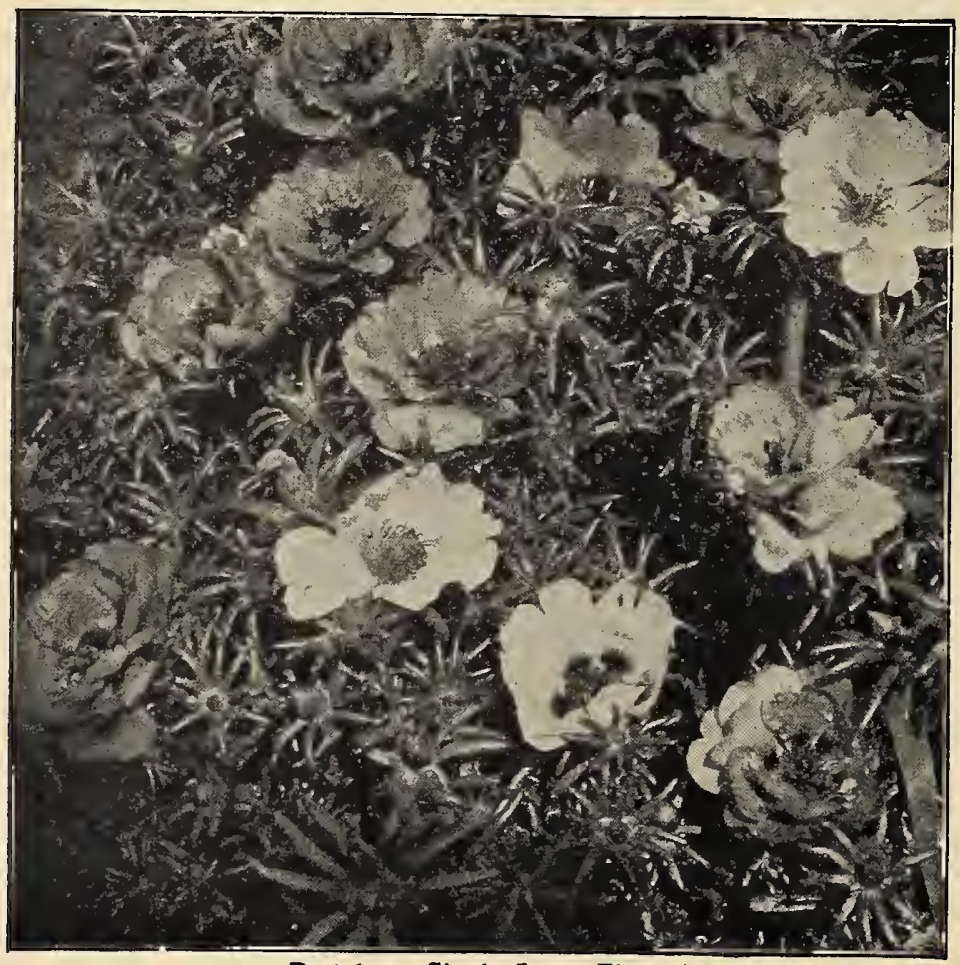

Portulaca, Single Large-Flowering
RHODANTHE. The pretty rose and white everlast- Pkt. ing flowers of this hardy annual are prized for winter bouquets. They succeed best in light soil. $1 \mathrm{ft}$.

Manglesii. Bright rose; free-flowering ........\$0 05

Mixed. Several colors..................... 05

\section{RICINUS (Gastor-oil Bean)}

Semi-tropical plants of large growth, mainly raised for their ornamental foliage. As centerpieces for beds of cannas and caladiums, or even when planted alone, they are very imposing. Pkt. Oz.

Borboniensis arboreus. Green-leaved; $15 \mathrm{ft} . \$ 0 \quad 05 \$ 015$ Cambodgensis. Splendid for groups; maroon

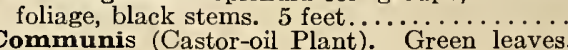

Gibsoni. Deep reddish violet. $5 \mathrm{ft}_{\text {. }} \ldots \ldots \ldots \ldots \ldots$

Panormitanus. Enormous dark brown leaves

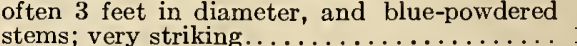
ztems; very striking..................... to 15 feet and have remarkably large leaves of green, purple and bronze. 05

Finest Mixed. Many varieties.............. 05 $05 \quad 20$

\section{RUDBECKIA}

Bicolor superba. Free-flowering annual with bright Pkt. yellow petals surrounding a dark brown disc. $2 \mathrm{ft} . \$ 0.05$ Bicolor superba semiplena. A double-flowering type of the preceding. It is easily grown, blooms very freely and from July until frost is covered with large, semi-double, golden yellow flowers. H. A.

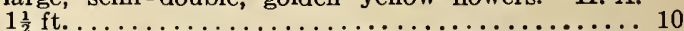

Newmani. The large orange-yellow flowers make a fine display in the garden during the fall months. Hardy perennial. $2 \frac{1}{2} \mathrm{ft} . \ldots \ldots \ldots \ldots \ldots . \ldots \ldots . . .10$

\section{PORTULACA}

There are few flowers that make such a dazzling display of color in the bright sunshine as a bed of Portulacas. It is not an unusual sight to see thousands of blossoms open at a single time, and ranging as they do through so many different shades. A light, dry soil and above all a sunny position is to their advantage. Sow the seed broadcast, very shallow in the open ground in May, and after once sown they usually resow themselves. H. A. $\frac{1}{2} \mathrm{ft}$.

\section{SINGLE LARGE-FLOWERING}

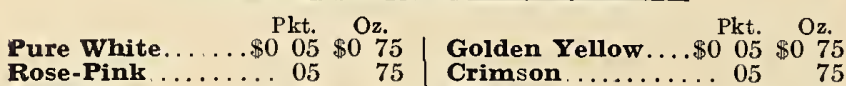

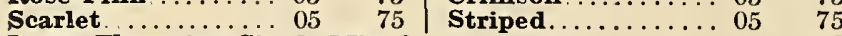

Large-Flowering Single Mixed ..................... 05

Collection, one pkt. each of above 6 separate colors, 25 cts.

\section{DOUBLE LARGE-FLOWERING}

Pure White. Pkt.

Pure Whitet.

\$0 10 Golden Yellow

10 Rose-Pink.

Pkt.

Large-Flowering Double Mixed ............. $\frac{1}{4} \mathrm{oz} .75 \mathrm{c} . \ldots 10$

\section{PYRETHRUM}

Fine, hardy plants blooming in May and June; valuable alike for cutting and bouquets. H. P.

Roseum hybridum, Comet-Flowered. The single Pst.

double fowers of this new hardy Pyrethrum measure 2 to 3 inches across and, unlike the old variety, the petals are attrac-

tively curled and twisted. Excellent for cutting. Mixed Colors $\$ 015$

Roseum hybridum grandiflorum. Single daisy-like flowers

borne on long stems, 2 feet or more in length; fern-like foliage. 10

Roseum hybridum, fl. pl. Handsome double flowers of white,

pink and all shades of red.

Aureum (Golden Feather). Fine for edging; golden yellow foli-

age, $1 \mathrm{ft}$. .

05

Aureum selaginoides. Finely cut, fern-like yellow foliage... 05

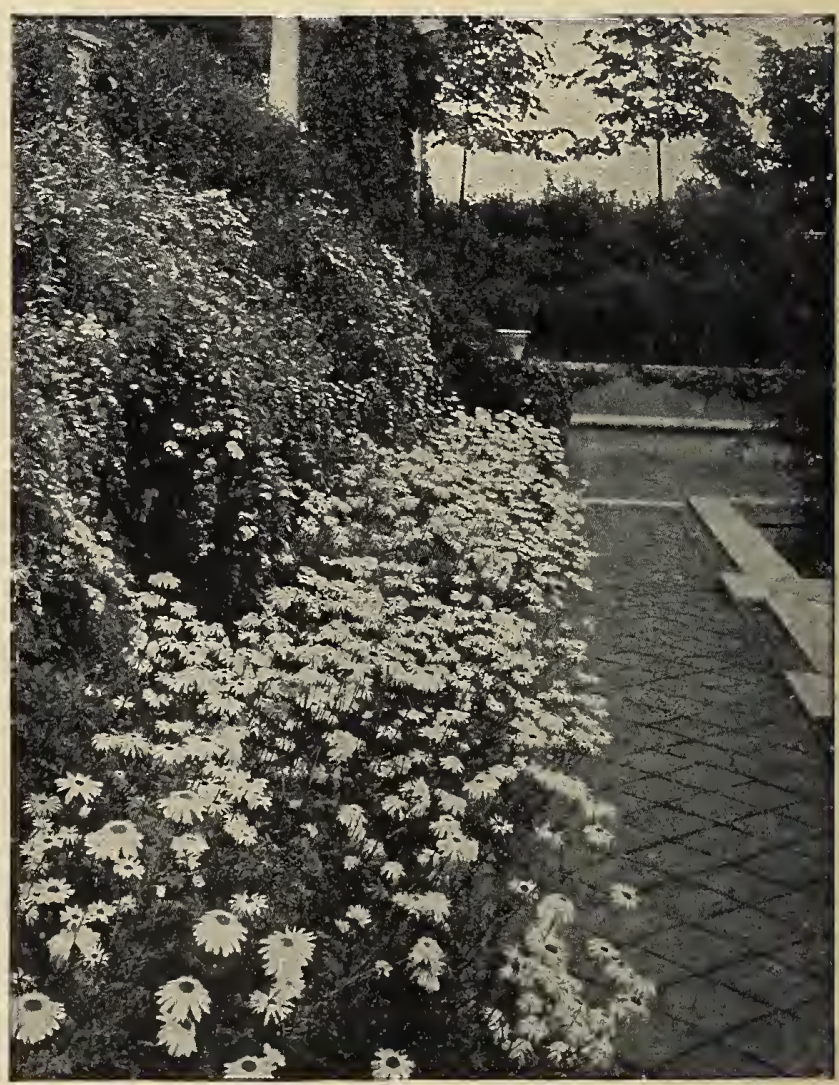

Pyrethrum, Roseum hybridum grandiflorum 


\section{SALVIA (Fire Plant)}

For an effective display of brilliant red-colored flowers, the Salvia is in a class by itself. It is one of the leading plants for bedding, forming oval bushes 2 to 3 feet high, which during the late summer and fall months are ablaze with fiery red flowers. To have plants for setting out in May, the seed should be started in February or March and kept in a warm place. H. H. $\mathbf{P}$.

Bonfire. (Clara Bedman). One of the finest and most popular Salvias for hidden by bedding. The plants grow into compact oval bushes and are almost Pkt. Ball of Fire. A dwarf early-blooming variety with large spikes of dazzling scarlet flowers. The plants, while not more than 2 feet high, are continually ablaze with flowers from July until late in fall...................

Zurich. This charming Salvia is of compact growth and particularly fine for spikes of fire-red fowers. $1 \frac{1}{2} \mathrm{ft}$. It is one of the earliest to bloom and has thick

Splendens. A tail-growing, free-blooming variety with large spikes of brilliant scarlet flowers. Makes a very effective bed. $3 \mathrm{ft} . \ldots \ldots \ldots \ldots \ldots \ldots$ oz. $\$ 1.50 \ldots \ldots$

\section{SALPIGLOSSIS}

Popular garden annuals of easy culture, growing about $1 \frac{1}{2}$ feet high. The open flowers, similar to petunias, are marked with the most beautiful colors. Splendid for cutting.

Pkt.

Large-Flowering. Finest mixed.

.\$0 05

Emperor. The flowers are rich and velvety in appearance, with wide-open throats, penciled and veined with gold. .

\section{0}

SANVITALIA procumbens, fl. pl. A charming dwarf annual, useful for small beds, edges or baskets; and covered all summer with double, bright-yellow flowers. The plants grow about 6 inches high and like verbenas are of trailing habit and prefer a sunny position. H. A. . . . . . . . . . . . . . . . . . . . 05

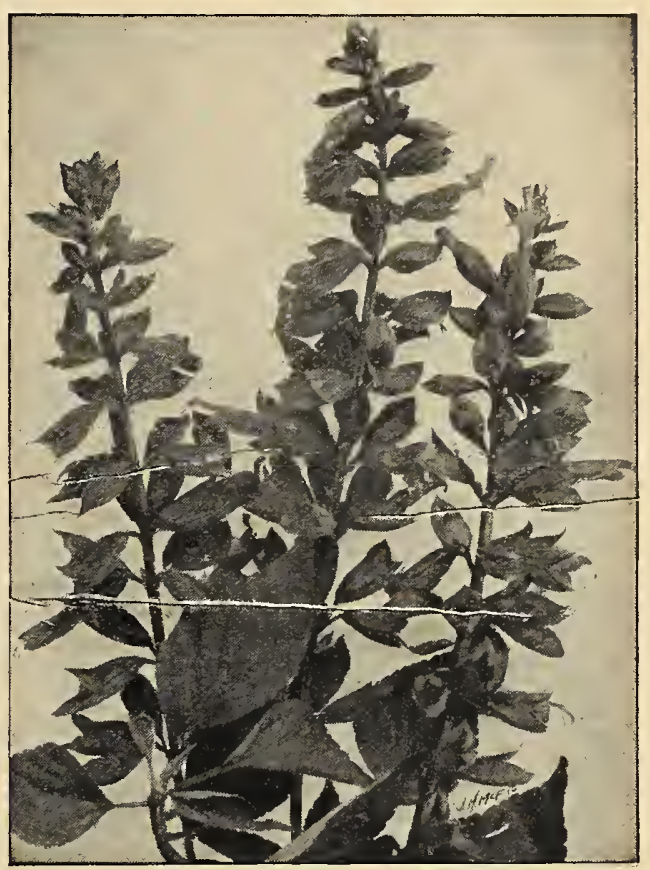

Salvia, Bonfire

\section{SCABIOSA (Mourning Bride)}

A favorite hardy annual succeeding well in almost any soil. The double, long-stemmed flowers are produced freely all summer and for cutting or bouquets will be found invaluable. The plants of the large-flowering Scabiosa grow about 2 feet high while those of the dwarf variety are not more than half that height. From seed sown outdoors in May, plants begin blooming- about July, but if convenient, sow indoors in March, and enjoy a longer season of bloom.

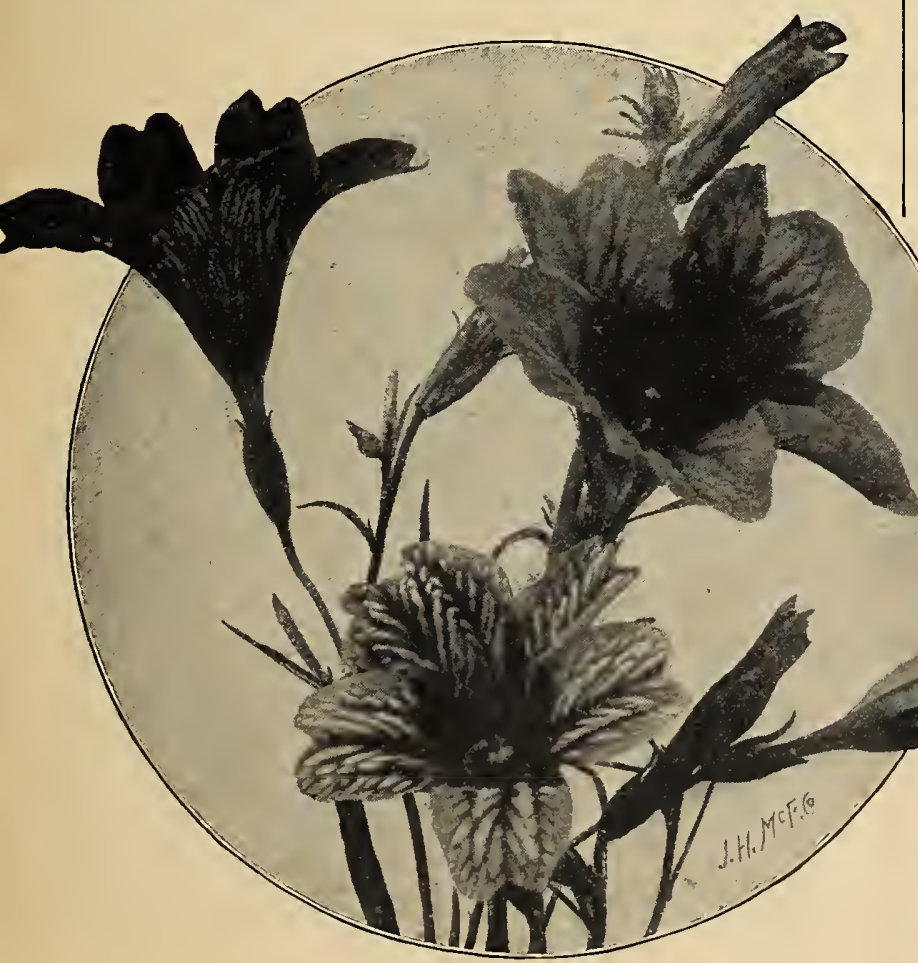

Salpiglossis, Large-Flowering

\section{DOUBLE LARGE- FLOWERING SCABIOSA}

Our customers would do well to try some of these lovely large flowering Scabiosas. They are easily grown, extremely pretty and from a small patch in the garden an abundance of flowers may be had until frost. The flowers are borne on long stems, very double and splendid for bouquets and vase decoration.

White. Pkt.

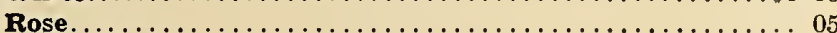

Cherry-Red............................. 05

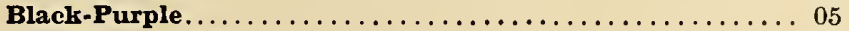

Azure Fairy. Lilac. ........................ 05

Mixed............................. oz. $75 \mathrm{c} . \ldots 5$

Dwarf Double Mixed. Of dwarf, compact growth not exceeding

$11 / 2$ feet in height, rendering it a most excellent plant either for

beds or borders ............................ 50 . . 05

Caucasica. A handsome hardy perennial for cutting. The bushes are of spreading form, about 3 feet high and bear many pretty lilac-blue flowers from 2 to 3 inches in diameter on long stems

\section{SCHIZANTHUS (Butterfly Flower)}

Pretty garden plants, blooming freely and covered with bright, gay-colored flowers which are not unlike a butterfly in appearance, and, from their range of rich and handsome colors, are often called "the poor man's orchid." They grow from $1 \frac{1}{2}$ to 2 feet high, and bloom in early summer. Pkt. Mixed Colors... S0 05

Wisetonensis. This large-flowering strain is exceptionally beautiful, and when in bloom the plants, with their multitude of white- and rose-spotted blossoms, present a wonderful sight. A most desirable plant for pot-culture, blooms in profusion during early spring. $11 / 2$ feet.................. 15

SEDUM cœruleum. (Stonecrop). Charming little plants with bright blue flowers, doing best in light soil. Fine for rockeries. H. A. ${ }_{1}^{1} \mathrm{ft}$. .

NASTURTIUMS, When planning your garden this spring Io not forget to reserve space for a bed or border of our large-flowering Nasturtiums. They are always attractive and very pretty for table decoration. 
SENSITIVE PLANT (Mimosa pudica). Very interesting plants, as the Pkt. leaves fold up when touched. Annual. ....................\$0 05 SMILAX (Myrsiphyllum asparagoides). A pretty climber having glossy oliagc; largely used by florists in decorating. G.P. $6 \mathrm{ft} . \ldots \ldots \ldots \ldots \ldots . . . . . .75 \mathrm{c} .$. SOLANUM Capsicastrum (Jerusalcm Cherry). Very interesting plants for greenhouse or window decoration. Plants are of dwarf branching habit and

their scarlet berries are very attractive. T. P. $1 \mathrm{ft}$.

SNAPDRAGON. See Antirrhinum.

\section{Stocks}

\section{Large-Flowering Dwarf Ten-Weeks}

For beauty, dazzling effect, and long continuance of bloom these large-flowering Stocks are unsurpassed. They are superior for bedding and pot-culture and largely grown by florists and also in the home garden. The plants are of dwarf, compact growth, about 12 to 15 inches high, while the flower-spikes are large and double, delightfully fragrant, and produced in endless profusion all summer. A wonderful range of colors is represented in this class. Our strain produces a large percentage of double flowers.

Light Blue.

Bright Rose

Blood-Red.

Pure White.

\begin{tabular}{|c|c|}
\hline Pkt. & \\
\hline & $\begin{array}{l}\text { Purple } \\
\text { Canary-Yellow }\end{array}$ \\
\hline & $\begin{array}{l}\text { If Ten-Weeks. Mixed colors. } \\
\text { st Mixed } \ldots \ldots \ldots\end{array}$ \\
\hline
\end{tabular}

\section{Giant Perfection Ten-Weeks}

This beautiful perpetual-blooming Stock grows about $1 \frac{1}{2}$ feet high and bears large spikes, thickly studded with rosette-like blossoms. For cutting this is considered one of the best, being of rather tall, branching growth, with one large central spike and many smaller side branches. Very early, fragrant, and valuable alike for greenhouse or garden. Pkt.

Brilliant Rose.

Light Blue. \$0 10

10 Fiery Crimson.

10 Pure White.......................... $\begin{array}{ll}\text { Pkt. } \\ \frac{1}{4} \text { oz. } \$ 1 & \$ 0 \\ \frac{1}{4} \text { oz. } \$ 1 & 10 \\ 10 & 10\end{array}$

STOKESIA cyanea (Cornflower Aster). This hardy perennial, with its large,

l.vender-blue, cornflower-like blossoms, 4 inches or more across, makes one of the most effective plants in the garden. It grows about 2 feet high, is splendid for cutting, and continues in bloom from July until October.

SUNFLOWER. See Helianthus.

SWEET AL YSSUM. See Alyssum.

SWEET ROCKET (Hesperis). A hardy perennial, growing from 2 to 3 feet high and producing spikes of single, sweet-scented, purple and white flowers. Mixed

SWEET SULTAN (Centaurea moschata). Hardy annuals with bright-colored flowers, on long, slender stems, which are splendid for Pkt. cutting and bouquets. $1 \frac{1}{2} \mathrm{ft}$. Mixed colors...

\section{SWEET WILLIAM (Dianthus barbatus)}

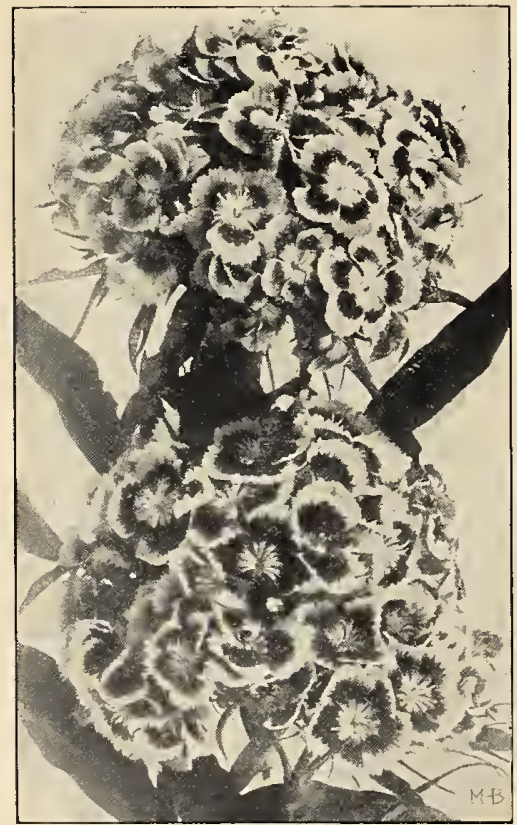

Sweet William, Dwarf Beauty
This ever-welcome hardy perennial, which has always been such a favorite in our grandmothers' gardens, is so well known that a description is hardly necessary. The plants grow from 1 to 2 feet high, and bear numerous heads of richly colored flowers, extremely fine for cutting and bouquets. Seed sown in July and August will produce blooming plants the second year. H. P. Brunjes' Dwarf Beauty. Finest of all Dwarf Sweet Williams. Our strain of Pkt. ever offered and should appeal to all lovers of this old-fashioned perennial. The dwarf bushy plants do not exceed 6 inches in height and the large heads of flowers appear in all colors

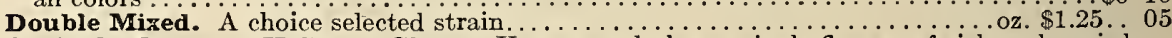
Auricula-flowered, Holborn Glory. Uncommonly large, single flowers of rich and varied

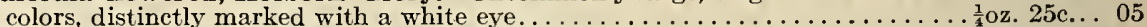

Single Mixed. Flowers of largest size and brightest colors. 2 ft................ $60 \mathrm{c} . . .05$ Single Dwarf Mixed. Its dwarf, compact growth makes it one of the best for bedding.... oz. $75 \mathrm{c} . . .05$

THUNBERGIA alata. A quick-growing, free-blooming annual climber especielly desirable for hanging-baskets and vases. Pretty flowers of buff, white, and orange, with dark eyes.

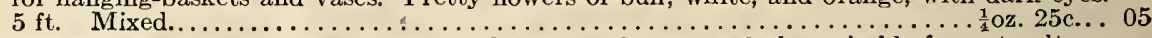
TORENIA Fournieri. Fine plants for the garden border and also suitable for pot culture. They are extremely showy and abundant bloomers. Light blue flowers, with three dark

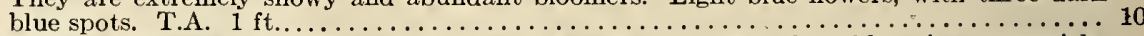

TRITOMA Uvaria grandiflora (Red-hot Poker Plant). Tall, long-blooming perennials,

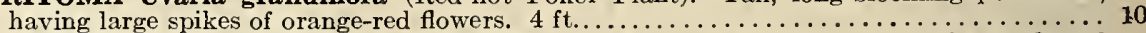
TROPAEOLUM canariense (Canary-bird Flower). A splendid climber with curiously shaped bright yellow flowers and fine-cut foliage. Blooms freely from July until frost. H.H.A. $2 \mathrm{ft}$.

VINCA (Periwinkle). Fine, free-blooming plants with glossy green leaves and bright rose and white flowers. They are excellent for bedding and if the seed is sown early they will bloom the first year. H. H. P. $2 \mathrm{ft}$. Mixed Colors....................... 05 VIOLA odorata (Sweet Violet). A well-known hardy perennial with sweet-scented, blue flowers. The seed of this variety is slow in germinating. $\frac{1}{2} \mathrm{ft} \ldots \ldots \ldots \ldots \ldots \ldots \ldots \ldots \ldots$

VIRGINIAN STOCK. Favorite little plants, 8 to 10 inches high, which are admired for

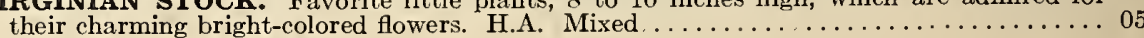




\section{H. B. \& SONS' MAMMOTH VERBENA}

Our choice strain of Mammoth Verbena, one of the most effective bedding plants, is unsurpassed for its brilliant colors and immense-size flowers. The plants, of spreading growth, are just covered with large heads of beautiful, colored flowers until late in autumn. Best results are obtained by sowing the seed early in the house or hotbed, but outdoor sowings may be made also in May. Annual. $\frac{1}{2} \mathrm{ft}$.

Skt.

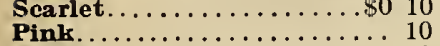

Purple....................... 10

Striped

Pkt.

Striped $\ldots \ldots \ldots \ldots \ldots \ldots \ldots \$ 010$

Whited................... 10

M. H. B. \& Sons'Invincible Remarkable for the size of its M. H. B. \& Sons Invincible. blooms and for the brilliancy and diversity of color. A grand strain saved from a large collection of named varieties. Mixed colors .................. Hybrida, Finest Mixed. Contains many colors; flowers of medium size. Very free flowering $\ldots \ldots \ldots \ldots \ldots \ldots \ldots \ldots \ldots \ldots \ldots \ldots \ldots \ldots \ldots$ Lemon Verbena (Aloysia citriodora). The light green leaves of this variety are sweetly scented and extensively used in bouquets. It may be planted in the garden for the summer and is very nice for the house or conservatory during the winter. $2 \mathrm{ft} \ldots \ldots \ldots \ldots \ldots \ldots \ldots$

WAFIENBERGIA (Platycodon). Handsome, hardy perennial bearing a profusion of large, bell-shaped flowers. For mixed beds and herbaceous borders these Chinese Bellflowers will be found very useful. Prefers a rich soil. 2 to $3 \mathrm{ft}$.

Grandiflora, Mixed. Blue and White.

\section{WALLFLOWER}

The Wallflower is particularly noted for its sweet fragrance and deserves to be more popular than it really is. To obtain fine plants for setting out in early spring, the seed should be sown in July and August, and the plants wintered over in coldframes. The plants are of strong, sturdy growth, well-branched and from $1 \frac{1}{2}$ to 2 feet high, rendering them most suitable for bedding. H. H. P.

\section{SINGLE LARGE.FLOW ERING}

Tom Thumb, Black-Brown. Plants dwarf and compact; rich, dark Pkt. brown flowers. 15 inches................. Single Mixed. Fine mixture... oz. $50 \mathrm{c} .05$

Single Annual, Paris Earliest. Blooms the first year from seed sown in February and March. Light brown flowers. .

Single Annual, Finest Mixed. All colors, including creamy white, blood-red, golden yellow and brown...

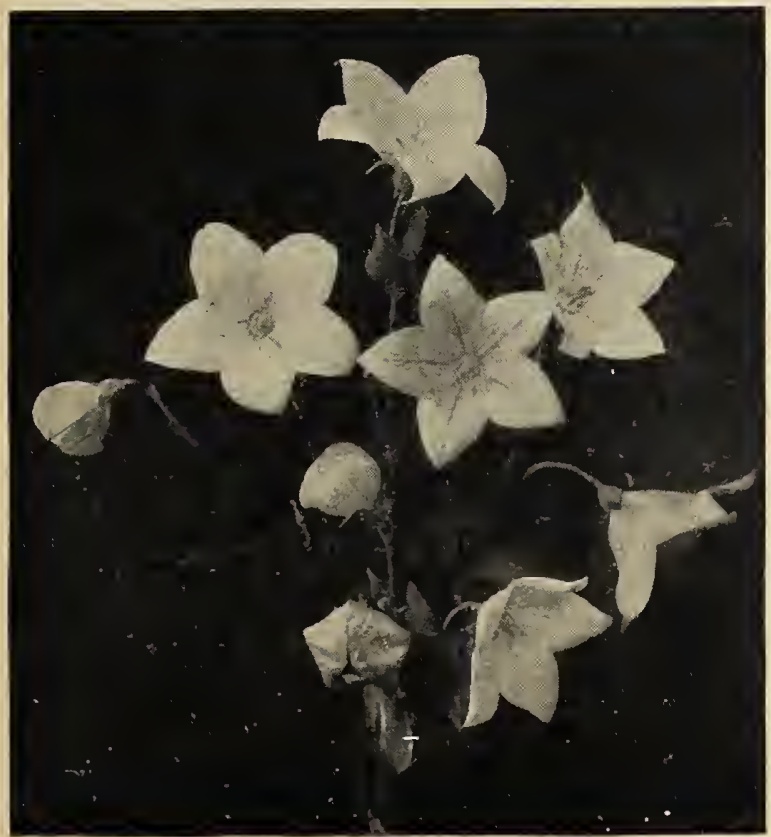

\section{WINTER-BLOOMING WALLFLOWER}

\section{(Cheiranthus Kezvensis)}

The flowers upon opening are sulphur-, then golden yellow and gradually change to purple-violet. Very fragrant and in bloom from November until spring. Sow seed in May or June and when large enough transplant to the garden; repot in the fall (September) for winter flowering. Pkt., 15c.

WHITLAVIA. The plants grow about 15 inches high and produce Pkt.

clusters of handsome cup-shaped blossoms. H. A. Mixed ......\$0 05 WILD CUCUMBER VINE. See Echinocystis.

XERANTHEMUM. A splendid "everlasting" for bouquets. An abundance of pretty, gracefully formed flowers of white, rose and purple are borne on compact bushes about 2 feet high. Sow seed in the open ground in May. H. A. Mixed colors. .

\section{WILD FLOWER GARDEN MIXTURE}

Although better results are obtained from the sowing of separate flower seeds, this mixture, which is composed cntirely of annuals, is very useful for sowing among shrubbery, along driveways or places that would otherwise look barren. It will produce a beautiful and gay effect all summer and supply plenty of flowers for bouquets. Sow the seed broadeast outdoors during May and June. Pkt. 5 cts., oz. 25 cts.

We have received many words of praise about our Asters. A fine collection of the best varieties will be found listed on pages 32,33 and 34 . 


\section{ZINNIA (Youth and Old Age)}

Of all the double flowers few equal these hardy annuals, with their profusion of bloom and everlasting flowers. Very easily grown from seed and whether in beds, borders, or groups they are always effective, the plants being continually covered with large double flowers from early summer until killed by frost. They are extremely useful to cut for bouquets. Sow seed outdoors in May and later set plants 1 foot apart each way.

\section{DWARF DOUBLE LARGE.FLOWERING. $1 \frac{1}{2} \mathrm{ft}$.}

These dwarf, large-flowering $\mathrm{Zinnias}$ are specially adapted for beds, borders, and massing and continue to bloom from early summer until frost.

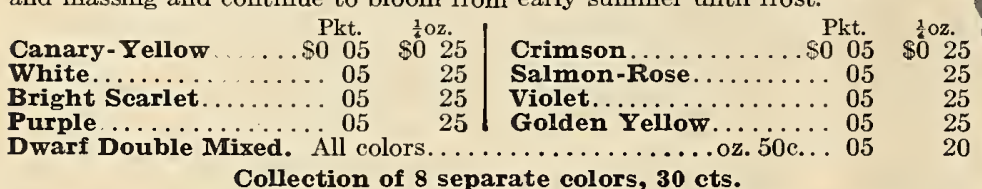

Zebra-Striped. A pretty class having the flowers striped in a peculiar, still Pkt. very attractive manner. For a showy display through the summer months a bed of this variety is unsurpassed. $1 \frac{1}{2} \mathrm{ft} . \ldots \ldots \ldots \ldots \ldots \ldots \frac{1}{4} \mathrm{oz} .30 \mathrm{c} . . \$ 010$

Curled and Crested. A distinct and beautiful type of this very popular annual. The flowers are large and well-formed, with odd but prettily curled and twisted petals, which adds to the grace and beauty of the flowers. Plants grow about $1 \frac{1}{2}$ feet high, are strong, well-branched, and remarkably free-flowering. One of the finest for cutting. Finest Mixed. $\frac{1}{4} \mathrm{Oz} .30 \mathrm{c} . . .10$

Tom Thumb. The dwarf bushy plants are ablaze with small, double flowers the whole summer; excellent for edges, borders, and beds. 9 in. Mixed.. 05

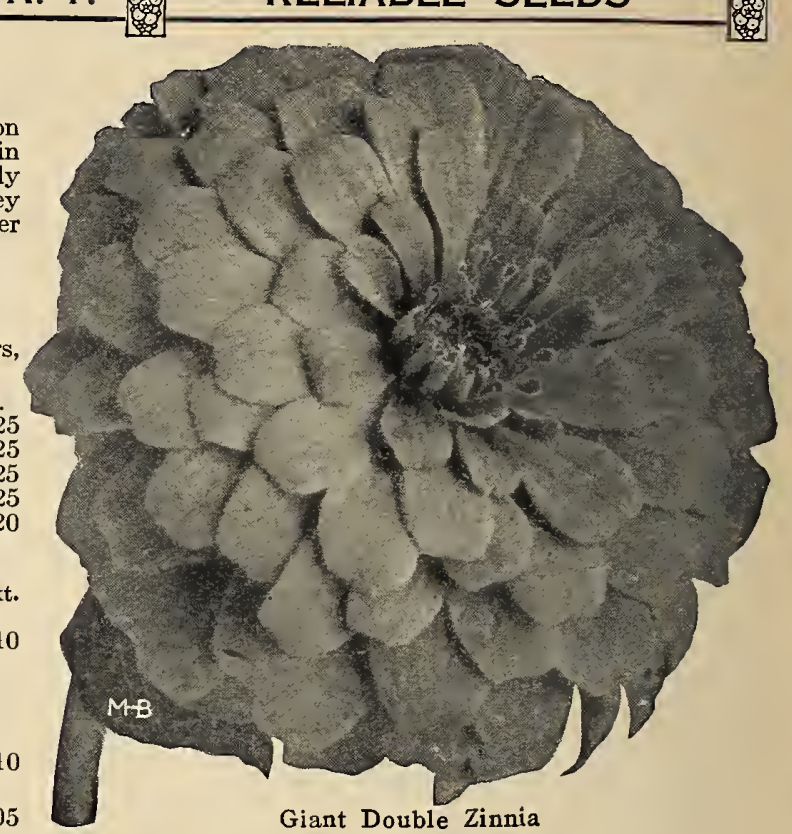

\section{BRUN.JES" GIANT DOUBLE ZINNIAS "Bloom All Summer"}

It does not necessarily require an expert gardener to obtain the best results from this exceptionally large-flowering strain of Zinnia as any amateur can have flowers to measure 5 inches and over in diameter. The flowers are not only extra large, but extremely double and present a most effective and brilliant display all summer. The plants should not be set too close as they are strong, robust growers attaining a height of 3 feet and spreading almost 2 feet across. Wherever planted, Giant Zinnias are always welcome and their massive flowers are the delight of the garden. Your flower-garden will not be complete without a planting of our Giant Double Zinnias.

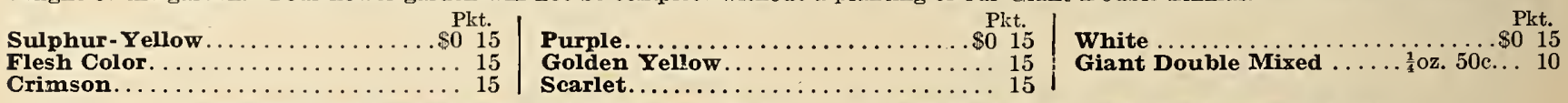
Crimson....

Collection, one packet each of any 2 colors, 25 cts. One packet each of the above 7 colors, 75 cts.

\section{Brunjes' Gollection of Popular Flowers}

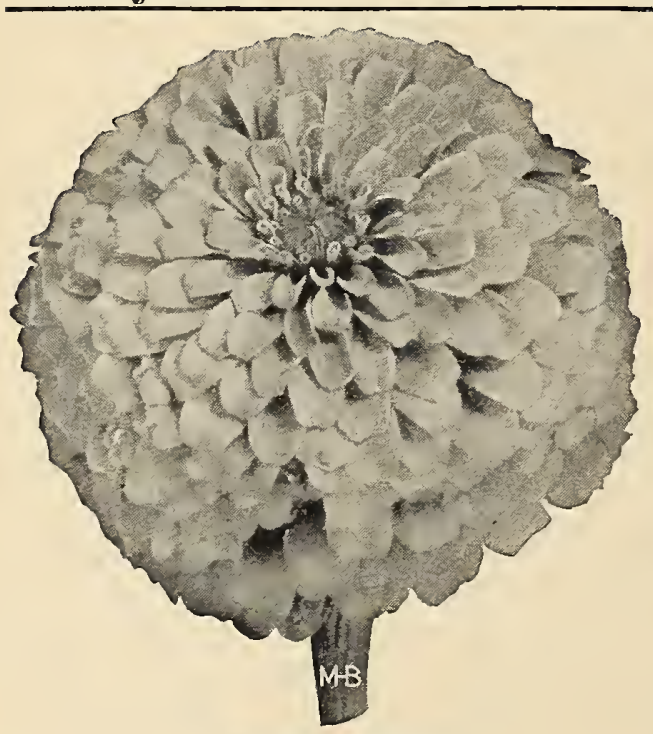

Dwarf Double Zinnia
Asters, Late - Branching Mixed.

Balsam, Double Roseflowered Mixed (Lady's Slipper).

Dianthus Chinensis, Double Mixed (China Pink.)

Pansy, Giant Trimardeau Mixed.

Petunia, Single Bedding Mixed.

Phlox Drummondi grandiflora, Finest Mixed.

Poppy, Double CarnationFlowered Mixed.

Mignonette, Machet.

Nasturtium, Dwarf or Tom Thumb Mixed.

Scabiosa, Double LargeFlowering Mixed.

Sweet Peas, Giant Orchid Flowered Mixed.

Zinnia, Dwarf Double Large-Flowering Mixed.

The above 12 packets, by mail, postpaid, 50 cts.

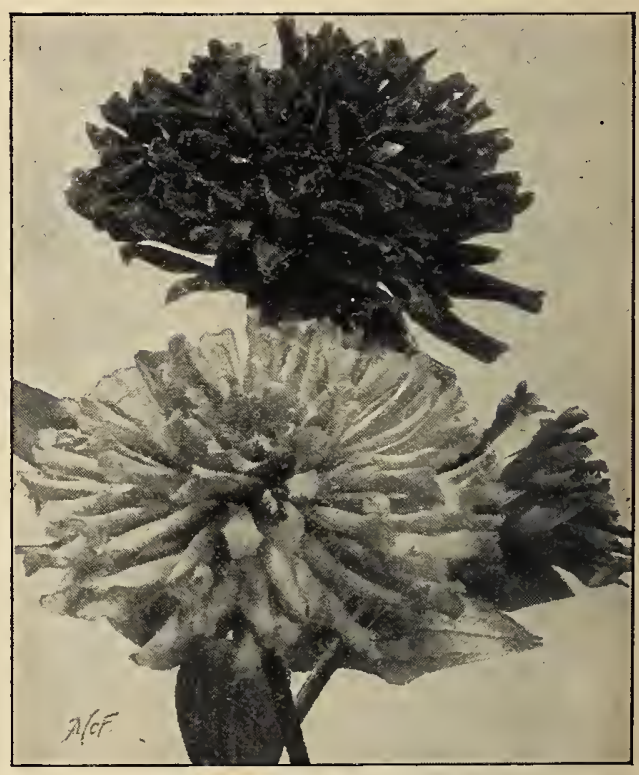

Curled and Crested Zinnias

\section{Brunjes' Central Park Lawn Grass \\ should always be used when you desire to make a fine lawn. It weighs 20 pounds to the bushel and is composed of the finest dwarf} evergreen grasses. We recommend it very highly as being the very best Lawn Grass mixture in the market. 


\begin{tabular}{|c|c|c|}
\hline \multicolumn{2}{|l|}{ M. H. BRUNJES } & \\
\hline
\end{tabular}

\section{Bulbs and Roots for Summer Flowers}

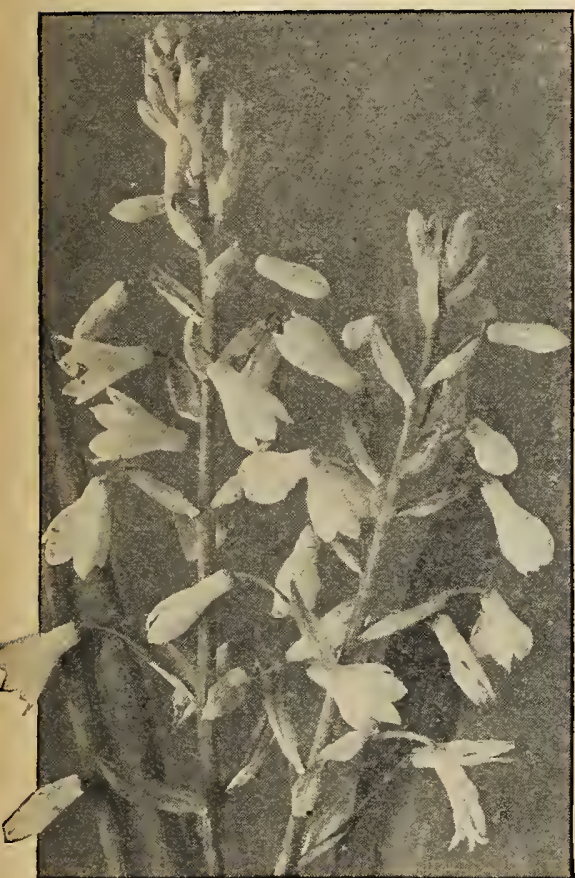

Hvacinthus candicans,

\section{AMARYLLIS}

Formosissima (Jacobæan Lily). Large, handsome, trumpet-shaped flowers of rich crimson-scarlet, which are borne on slender stalks well above the long, narrow, dark green leaves. It may be planted in pots for house culture or in the open ground during May, blooming either in June or July. Large Bulbs, 15 cts. each, $\$ 1.50$ per doz. By mail, add 3 cts. each, extra

\section{GINNAMON VINE}

A hardy, rapid-growing climber with bright green, heart-shaped leaves and small, snow-white, cinnamon-scented flowers. Extra-large Bulbs, 8 cts, each, 75 cts. per doz.; postpaid, 85 cts.

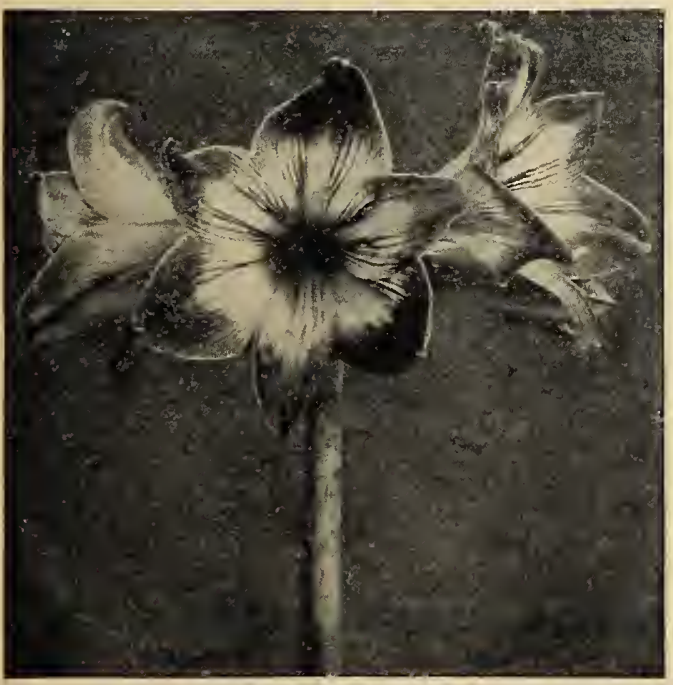

Amaryllis

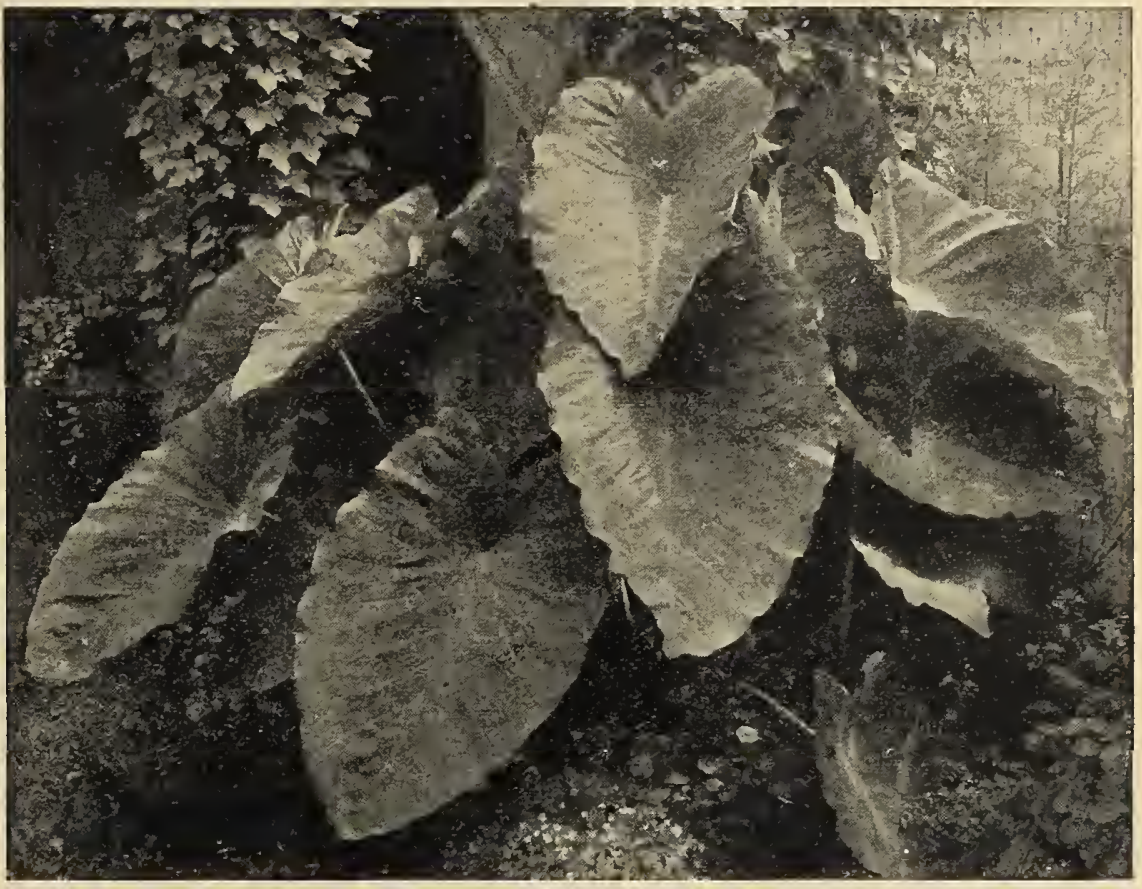

Caladium (Elephant's Ear)

\section{GALADIUM ESGULENTUM}

(Elephant's Ear)

When planted in beds or borders, the Caladium is very effcctive. The large, light green leaves are of enormous dimensions, often measuring 3 feet long and 2 feet in width. Grows in any good garden soil.
Large Bulbs

Extra-Large Bulbs

Jumbo, or Mammoth Buibs

Above shipped by express, not prepaid Each Doz $\$ 0 \quad 20 \quad \$ 2 \quad 25$ $\begin{array}{lll}20 & \$ 2 & 25 \\ 25 & 2 & 75\end{array}$ $30 \quad 3 \quad 25$

\section{MADEIRA VINE}

This popular, quick-growing climber has thick, glossy green leaves and fragrant, feathery, white flowers.

Large Bulbs, $8 \mathrm{cts}$. each, 75 cts. per doz.; postpaid, $90 \mathrm{cts}$.

\section{HYACINTHUS CANDICANS}

Pure white, bell-shaped flowers are suspended gracefully from the long, slende 1 spikes which grow from 3 to 4 fcet high. Often 20 to 30 flowers liave been counter on one stem. Very cffective when planted in clumps.

Large Bulbs, $8 \mathrm{cts}$. each, $75 \mathrm{cts}$. per doz. If by parcel post, add postage at zone ratc. Weight, 3 lbs. per doz.

\section{HAR DY GLIMBERS}

\section{By express only, at purchaser's expense}

CLEMATIS Jackmanii. Large, purple flowers. Strong, 2-ycar-old, ficld-grown plants. 50 cts. each.

CLEMATIS paniculata. Small, white, fragrant flowers. Strong, 3-year-old, fieldgrown plants. $50 \mathrm{cts}$. each.

HONEYSUCKLE, Hall's Japan (Halleana). White, turning to yellow: fragrant. 30 ets. each, $\$ 3.25$ per doz 


\section{Brunjes' Cannas}

Cannas are, without doubt, one of the best and most popular of all plants for bedding. They are largely planted in the public parks of Brooklyn, where they are admired from early summer until killed by frost. The plants grow from 3 to 6 feet high, have massive green and bronze foliage and large, handsome flowers measuring up to 7 inches across. Roots should not be set outdoors before May.

IF BY PARCEL POST, ADD POSTAGE AT ZONE RATE. ONE DOZ. WEIGH 3 LBS. ADD 3 CTS. EACH FOR SINGLE ROOTS

Austria. A splendid orchid-flowered variety with canary-yellow flowers, of extra-large size, blooming profusely throughout the summer. Green foliage. 4 to 5 feet. 8 cts. each, 75 cts. per doz.

Brandywine. Magnificent, dark bronze-leaved Canna, growing about 5 feet high, the flowers of which are bright red. $8 \mathrm{cts}$. each, 75 ets. per doz.

Charles Henderson. This favorite erimson variety, although growing only $3 \frac{1}{2}$ feet high, will be found satisfactory for bedding, either alone or with the brighter-colored sorts. Green foliage. 8 cts. each, 75 cts. per doz.

Firebird. The finest red Canna introduced in many years, in irebird. fact we consider this the best red-flowered, greenleaved, variety in our list. The flowers are very large, formed in immense trusses and carried well above the leaves. 4 feet. 15 cts. each, $\$ 1.50$ per doz.

Florence Vaughan. The flowers of unusually large size are bright golden yellow, spotted with red. Plants will not exceed 5 feet in height. Green foliage. 8 cts. each, 75 cts. per doz.

Gladiator. A strong, vigorous-growing, green-leaved Canna, Io about 4 to 5 feet high, having bright yellow, crimson-spotted flowers. $10 \mathrm{cts}$. each, $\$ 1$ per doz.

Gladioflora. In shape the blossoms very much resemble a arge gladiolus. The plants grow about $31 / 2$ feet high and have green foliage; flowers bright crimson, changing to carmine, edged with gold. 10 ets. each, $\$ 1$ per doz.

Hungaria. A lovely new Canna and one of the very best pink blush-pink and are produced freely until late fall. Green foliage. $31 / 2$ feet. 10 cts. each, $\$ 1$ per doz.

King Humbert. Of all the varieties, this one is especially specimens. The superb orange-scarlet flowers are of enormous size, and, with the massive bronze foliage, few Cannas are more effective. 5 feet. $10 \mathrm{cts}$. each, $\$ 1$ per doz.

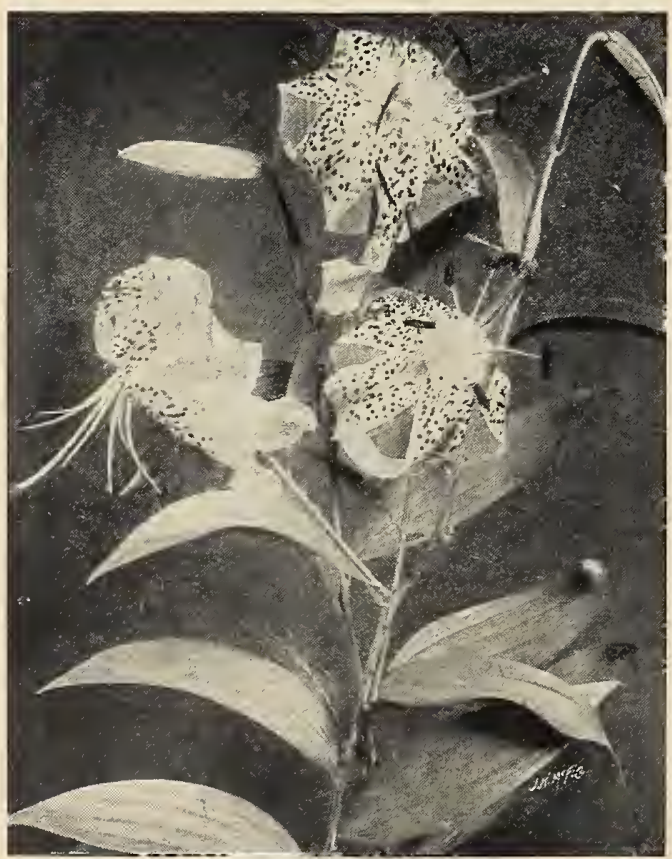

Lilium speciosum rubrum

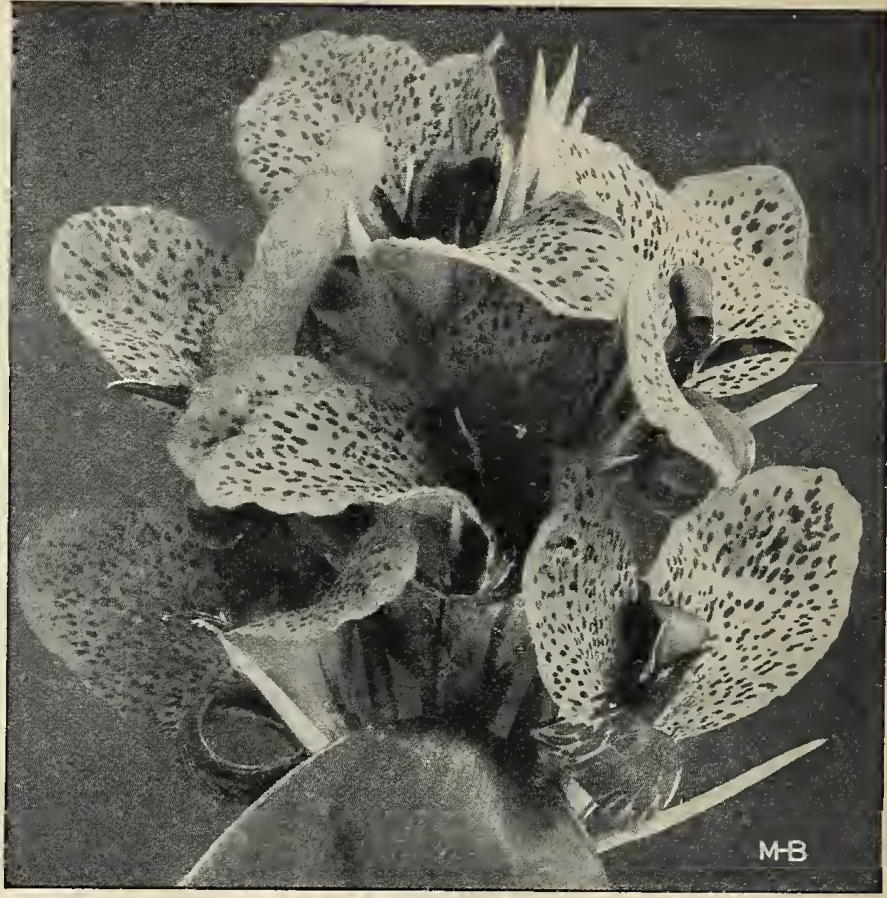

Canna, Gladiator

Niagara. Splendid for bordering taller Cannas. Color deep crimfoliage. 3 feet. $10 \mathrm{cts}$. each, $\$ 1$ per doz.

Pennsylvania. A superior, green-leaved, orchid-flowered Canna, with remarkably large, deep scarlet flowers, of ten measuring 6 inches in diameter. Free bloomer. 6 feet. 10 cts. each, $\$ 1$ per doz.

Queen Charlotte. The foliage is dark green, while the crimsonscarlet flowers are bordered with a broad band of bright yellow. Bright and showy. 4 feet. 8 cts. each, 75 cts. per doz.

Richard Wallace. One of the best yellow-flowering Cannas for bedding. foliage. $10 \mathrm{cts}$. each, $\$ 1$ per doz.

Venus. This is undoubtedly the daintiest of all Cannas. Its pretty pink flowers enus. are slightly tinted at the edges with creamy yellow. Green foliage. $3 \frac{1}{2}$ feet. $10 \mathrm{cts}$. each, $\$ 1$ per doz.

Yellow King Humbert. A beautiful orchid-flowering Canna of recent inwith bright scarlet and equally as large as the well known King Humbert. Green foliage. 4 feet. $10 \mathrm{cts}$. each, $\$ 1$ per doz.

\section{JAPANESE LILIES}

Lilies, with their stately growth and magnificent-colored flowers, many of them beautifully spotted, form a splendid appearance in the herbaceous border, where they should remain for years undisturbed. Plant as soon as the ground is open in spring. Set bulbs 6 inches deep, placing a handful of sand at the bottom of each.

Auratum (Golden Banded Lily). Handsome flowers of pure white, freely spotted with crimson and has a broad band of rich yellow running through the center of each petal. Very fragrant and blooms the latter part of July. 35 cts. each, $\$ 4$ per doz.

Speciosum album. One of the hardiest garden Lilies, with fragrant flowers of purest white, blooming in August. 35 cts. each, $\$ 4$ per doz.

Speciosum Melpomene. A magnificent variety. Pure white flowers of immense size, heavily spotted with crimson. 35 cts. each, $\$ 4$ per doz.

Speciosum rubrum. Very pretty white Lilies thickly spotted with crimson. 35 cts. each, $\$ 4$ per doz.

Tigrinum splendens. An improved Tiger Lily growing about 4 feet high. Large flowers of orange-salmon with black spots. 25 cts. each, $\$ 2.75$ per doz.

IF BY PARCEL POST, ADD 3 CTS. EACH EXTRA 


\section{BRUNJES' SUPERB DAHLIAS}

Although of easy culture, Dahlias should be planted in an open position, where they have plenty of air and receive the full benefit of the sun. A deep, rich soil is also necessary. Begin planting early in May and until the latter part of Junc, placing the roots 3 feet apar' and 4 inches below the surface. As the shoots appear, all but two or three of the strongest should be eut-away.

If by parcel post add postage at zone rate. Weight, $1 \mathrm{lb}$. each.

\section{SHOW AND DECORATIVE DAHLIAS}

A. D. Livoni. The plants, while not more than $3 \frac{1}{2}$ feet high, are literally covered with very full-double flowers of clear, soft pink. $20 \mathrm{cts}$. each, \$2 per doz.

Arabella. Large pale primrose, tipped and shaded rose and lavender. Blooms early and profusely. $20 \mathrm{cts}$. cach, $\$ 2$ per doz.

Dorothy Peacock. This fine introduction is considered the most beautiful of all pink Show Dahlias, and we are sure will be admired by all. $35 \mathrm{cts.}$ each, $\$ 4$ per doz.

Jack Rose. This handsome Decorative Dahlia has the rich, dazzling crimson color of the famous General Jacqueminot rose. $25 \mathrm{cts}$. each, $\$ 2.50$ per doz.

Le Grand Manitou. (Dec.) A grand of the very best variegated or fancy varieties. Flowers very large, 5 to 6 inche across, beautifully striped, blotched, and marbled reddish violet on white ground occasionally the flowers are solid reddish violet. 35 cts. each, $\$ 4$ per doz.

Miss Minnie McCullough. A distinct and lovely, fancy Decorative Dahlia. The color is a glorious autumn shade, soft yellow overlaid with bronze arf tipped red. 25 cts. each, $\$ 2.50$ per doz.

Red Hussar. The dazzline crimson-scarlet flowers of medium size are produced abundantly on long, stiff stems. 18 inches to 2 feet in length. Splendid for cutting. 20 cts. each, $\$ 2$ per doz.

\section{Souvenir de Gustave Doazon.}

Considered the largest of all Dahlias, the rich, orange-scarlet flowers often measuring 9 inches across. It is an early and profuse bloomer, good strong grower, and one of the most popular Decorative varieties. 25 cts. each, $\$ 2.50$ per doz.

White Swan. Large, double flowers of purest white. $20 \mathrm{cts}$. each, $\$ 2$ per doz.

W. W. Rawson. The massive, double white, shaded with flowers are pure lavender, of perfect long stems. A very pretty and delicate color and a beautiful Dahlia for cutting. $35 \mathrm{cts}$. each, $\$ 4$ per doz.

Yellow Colosse. The large, showy flowers of pure primrose-yellow are produced freely on long stems. 35 cts. each, $\$ 4$ per doz.

\section{CACTUS DAHLIAS}

Countess of Lonsdale. It is one of the finest of the Cactus varieties, prized for its handsome, salmon-colored flowers, and unequaled for its abundance of bloom. 25 cts. each, $\$ 2.50$ per doz.

General Buller. A charming Cactus Dahlia of rich, velvety crimson, tips of petals pure white. 25 cts. each, $\$ 2.50$ per doz.

Kriemhilde. Very showy flowers of delicate pink changing to white in the center are produced in the greatest profusion. 25 cts. each, $\$ 2.50$ per doz.

Prince of Yellows. Rich canary-yellow petals, rather broad and somewhat fringed at the edges, forming a distinctly pretty flower. 25 cts. each, $\$ 2.50$ per doz.

Ruth Forbes. Strong, vigorous-growing plants, bearing many blooms of mammoth size on long, wiry stems. The color is a beautiful, elear pink. 25 cts. each, $\$ 2.50$ per doz.

Standard Bearer. A very popular, largeflowering variety of true Cactus form, with brilliant, fiery scarlet flowers. $25 \mathrm{cts}$. each, $\$ 2.50$ per doz.

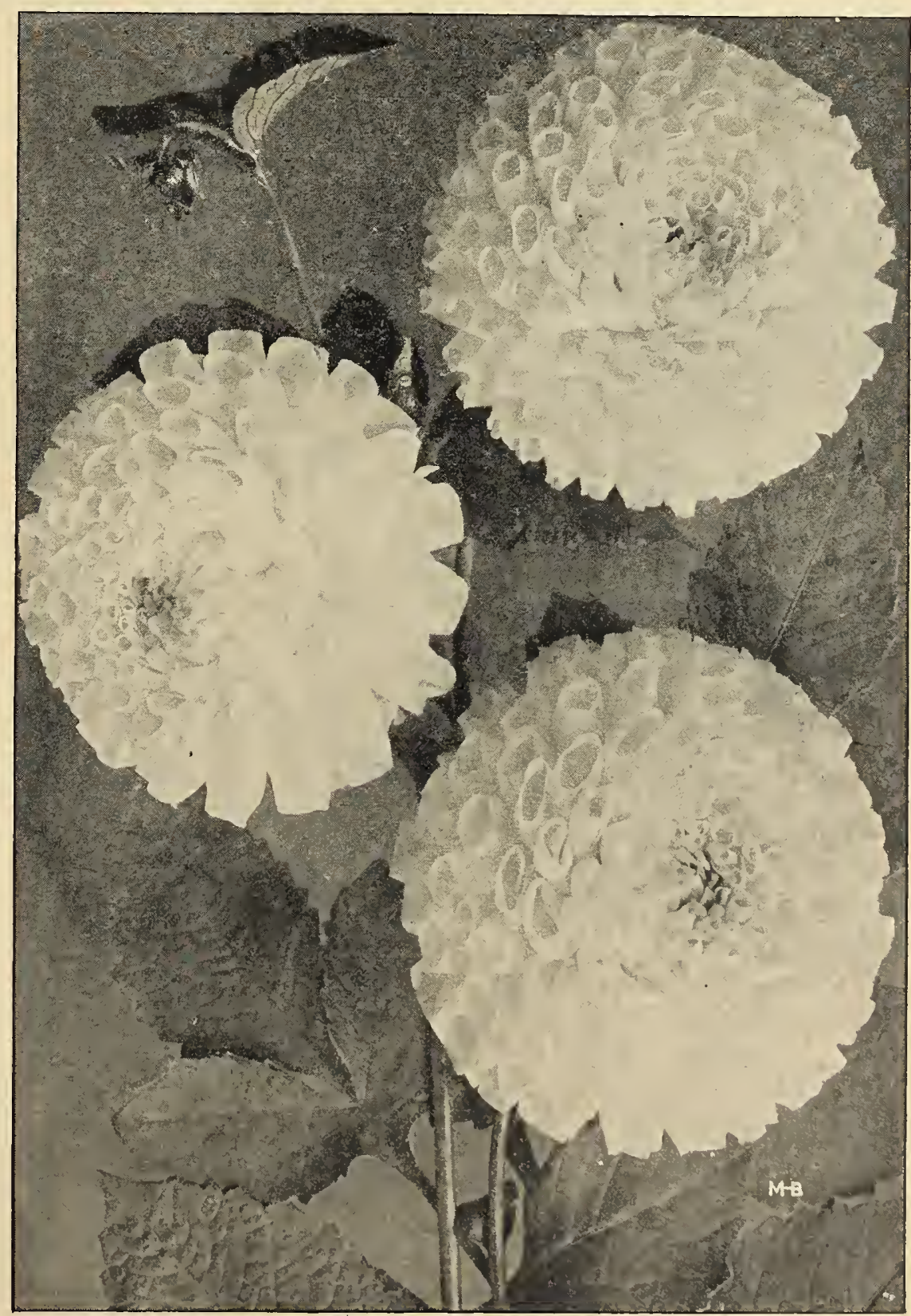

Dahlia, W. W. Rawson reer's White. Aning snow-white flowers The large, glise quite dwarf, only 3 feet high, and noted for their free blooming, being filled with flowers until late fall. 35 cts. each, $\$ 4$ per doz.

Delice. (Dec.) The popular rose-pink Dahlia for eutting. Flowers are of large size, well formed and borne on long stems. A splendid Dahlia and well recommended for the garden. 35 cts. each, $\$ 4$ per doz. 


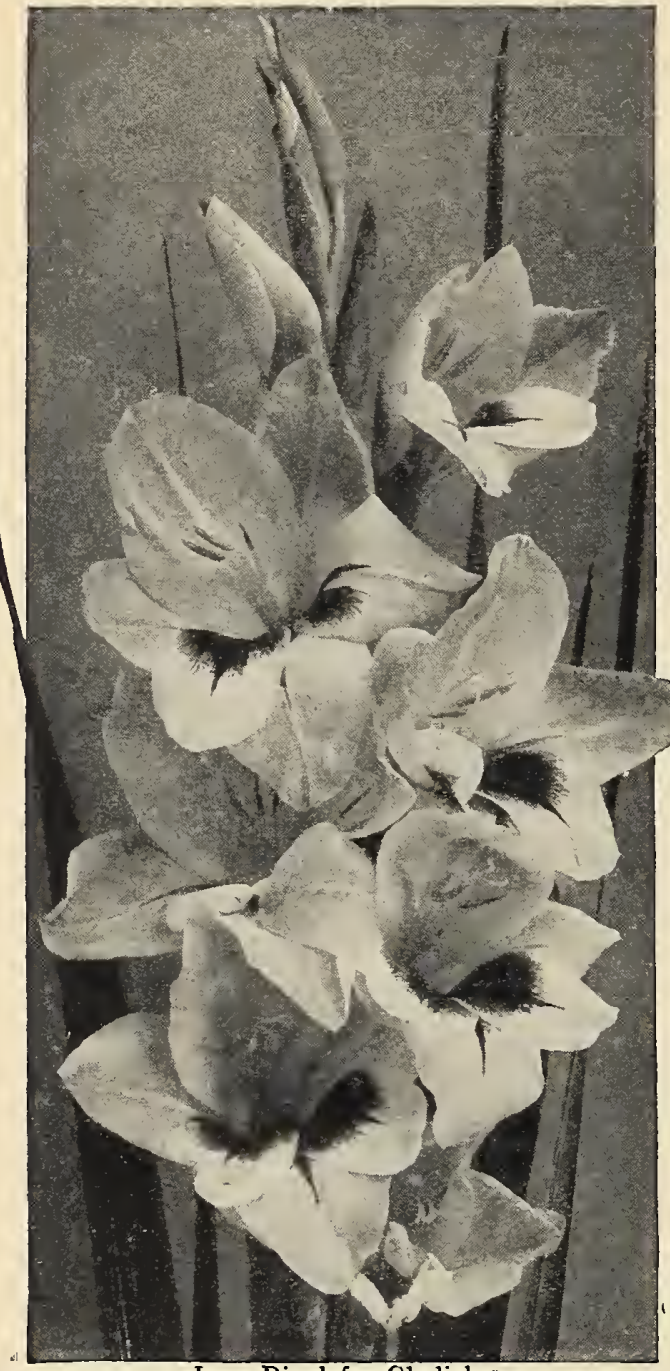

Jane Dieulafoy Gladiolus

\section{PEONIES}

One of the most popular hardy plants in cultivation today. They will stand the severest winter with little or no protection, and during June afford a display that words can hardly describe. Every garden should have one or more of these handsome plants which, year after year, grow more beautiful and often carr from twenty to thirty flowers. The flowers are of enormous size, perfectly double, sweetly scented and borne on long, stiff stems, which render them excellent for cutting. To obtain best results they should be planted in deep, rich soil, to which a liberal amount of well-decayed manure has been added, with a covering of about 3 inches over the top of the roots and left undisturbed.

The following can be sent by express only at the purchaser's expense

Named varieties of Double White, Double Pink and Double Red. $50 \mathrm{cts}$. each.

\section{TUBEROSE}

The pure white double flowers form on long stems 3 feet high and are very fragrant. They usually bloom in September. To obtain best results do not plant bulbs before May 15 .

Double Excelsior Pearl. 75 ets. per doz., $\$ 5.75$ per 100 . Add postage at zone rates. One dozen weigh $1 \frac{1}{2} \mathrm{lbs}$.

Mammoth Bulbs. 90 ets, per doz., $\$ 6.75$ per 100 . Add postage at zone rates. One dozen weigh $2 \frac{1}{2}$ lbs. U1 1 C 10101 IF BY PARCEL POST, ADD POSTAGE AT ZONE RATE. ONE MAILED FREE.

After years of careful improvement, the Gladiolus is today one of the most beauiful of all summer-flowering bulbs. Even in ordinary garden soil few will give such emarkable results with so little eare. Bulbs should be planted 4 to 6 inches apart nd 3 to 5 inches deep according to the size of bulbs, from April 15 to June 15.

\section{TWELVE BEAUTIFUL GLADIOLI}

America. Undoubtedly one of the best and most largely planted pink Gladioli for cutting. Its beautiful, lavender-pink flowers are of the largest size, $75 \mathrm{cts}$. per doz., $\$ 5.75$ per 100 .

Baron Hulot. A rare and lovely shade of dark violet-blue; exceptionally fine and decorative. $10 \mathrm{cts}$. each, $\$ 1$ per doz.

Canary-Bird. In color a clear canary-yellow; one of the best and most pleasing of the yellow varieties; large, well-formed flowers. 12 cts. each, $\$ 1.25$ per doz.

Paul. Giant flowers of deep crimson, slightly stained yellow and spotted

ane Dieula foy. A striking Gladiolus with extra-large, creamy white flowers, the lower petals stained maroon. One of the finest in our list. Kunderdi Glory. A distinct and pretty variety with large, ruffled flowers of 12 cts. each, $\$ 1.25$ per doz.

rs. Francis King. An attractive variety, with light scarlet, wide-open fowers Should be included in every collection. $7 \mathrm{cts}$. each, 75 cts. per doz., $\$ 5.75$ per 100 anama. A seedling of the famous Gladiolus, America, and sure to become just as popular. Large flowers of rose-pink. One of the finest. $10 \mathrm{cts}$. each,

Peace. The beautiful white flowers of this new introduction have pale lilac featherHeavy, rich green foliage. $10 \mathrm{cts}$. each, $\$ 1$ per doz.

Princeps. One of the largest-flowered Gladioli. Rich scarlet-crimson flowers, the Peeps. lower three petals being blotched with white. $10 \mathrm{cts}$. each, $\$ 1$ per doz. Scribe. Both the individual flowers and spike are of enormous size, making a grand Wild Rose. Flowers of good size and a delicate shade of bright rose and blush. A pretty Gladiolus which we are sure will be admired by all. 12 cts. each, $\$ 1.25$ per doz.

COLLECTION: One each of the above 12 named sorts, $\$ 1.10$, postpaid

\section{Mixtures of Gladioli}

Brunjes' Giant Mixed Every shade and color is included in this mixture, remarkable size. $60 \mathrm{cts}$. per doz., $\$ 4$ per $100, \$ 37$ per 1,000

terix's Mixed Hybrids. A superb mixture comprising every shade known in Gladioli. 50 cts. per doz., $\$ 3.50$ per $100, \$ 32$ per 1,000 .

uccess Mixture. Contains a wide range of colors and is the best mixture offered considering the price. 35 cts. per doz., $\$ 2.50$ per $100, \$ 22$ per 1,000 .

\section{OXALIS (Summer-Flowering)}

Pretty free-flowering plants, having clover-like foliage; extensively used for bordering. Bloom early and continuously throughout the summer. Plant bulbs inches apart. osea. Rosy pink; mammoth bulbs, 20 cts. per doz., $\$ 1.25$ per 100

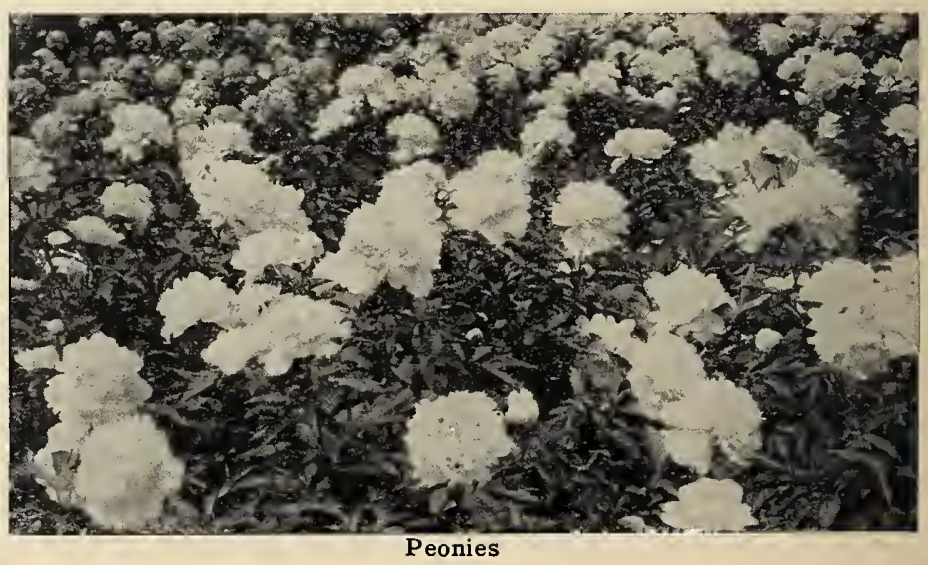




\section{Coldwell's Lawn Mowers}

Imperial Lawn Mower (High Wheel). This high- Each wheel Mower is one of the very best for all purposes, and has been a favorite with our customers for many years.

14-inch, four blades. . . . . . . . . . . . . . . . \$18 00 16-inch, four blades. . . . . . . ........... 1900 18-inch, four blades.................. 2000

Rajah Lawn Mower. Highly recommended as one of the very best high-wheel, ball-bearing Mowers. It cuts evenly, runs smoothly, and leaves the lawn in fine condition after cutting.

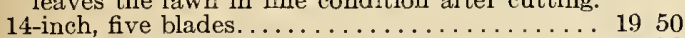
16-inch, five blades. ................... 2050 18-inch, five blades.................... 2150

Colonial Lawn Mower. A $\mathrm{A}$ low-wheel, ball-bearing machine, especially recommended for small lawns.

12-inch, four blades. . . . . . . . . . . . . . . 1000

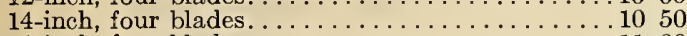

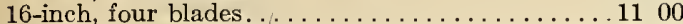

18-inch, four blades.

Cadet Lawn Mower. A popular, low-priced Mower.

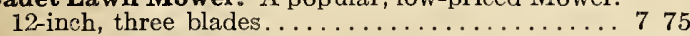

14-inch, three blades................... 800

16-inch, three blades................. 825

18-inch, three blades.................. 850

\section{Lawn Trimmer (Ball-bearinğ)}

A handy and useful machine for trimming the grass close to fences, walls and around trees and shrubbery.10 50

\section{Grass Catchers}

Can be used on ail the above mowers, with the exception of the lawn trimmer.

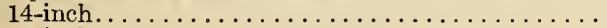

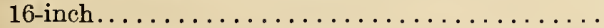

\section{The Dunham Water-Weight}

\section{Roller}

The drum is made of heavy steel plates carefully Each welded together to form a solid one-piece container for the water. The edgings of the drum are nicely rounded and will not cut or mar the lawn or tenniscourt. It is strong, durable, and easy rolling. Weight, empty, 80 pounds; filled with water, 310 pounds...........................\$22 50

\section{Lawn Sprinklers}

Tuxedo. Has a brass top, as shown in the cut, made firm by being screwed down on an iron sled, the base of which is $7 \frac{1}{4} \times 7 \frac{1}{4}$ inches................

Preston. An ideal sprinkler for a small garden. With the exception of the sled it is all brass, and

stands about 6 inches high .......................... Made exactly as the California, but has

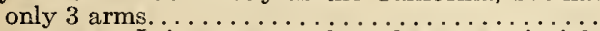

Columbia. It is constructed on the same principle as the Preston, but has 3 legs instead of the sled at the base..................................... arms of which are arranged to cover a large area..

stna. Stands 24 inches high and has 3 arms. The top is made the same as the Preston. The base is formed of 3 legs, each of which terminates in a solid ball....................................... The

Texas. There is no difference between the Texas

eck's Lawn Sprinkler. 4-arm, nickel plated. . . . .

A fountain attachment is included with Peck's Lawu Sprinklers.

Water Witch....................... 65

All items listed above sent by express or freight at purchaser's expense

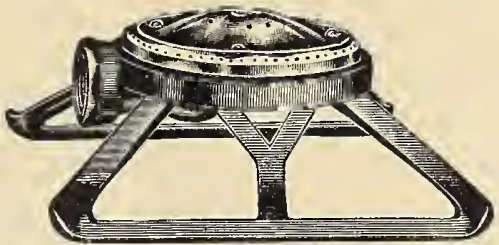

Tuxedo Lawn Sprinkler
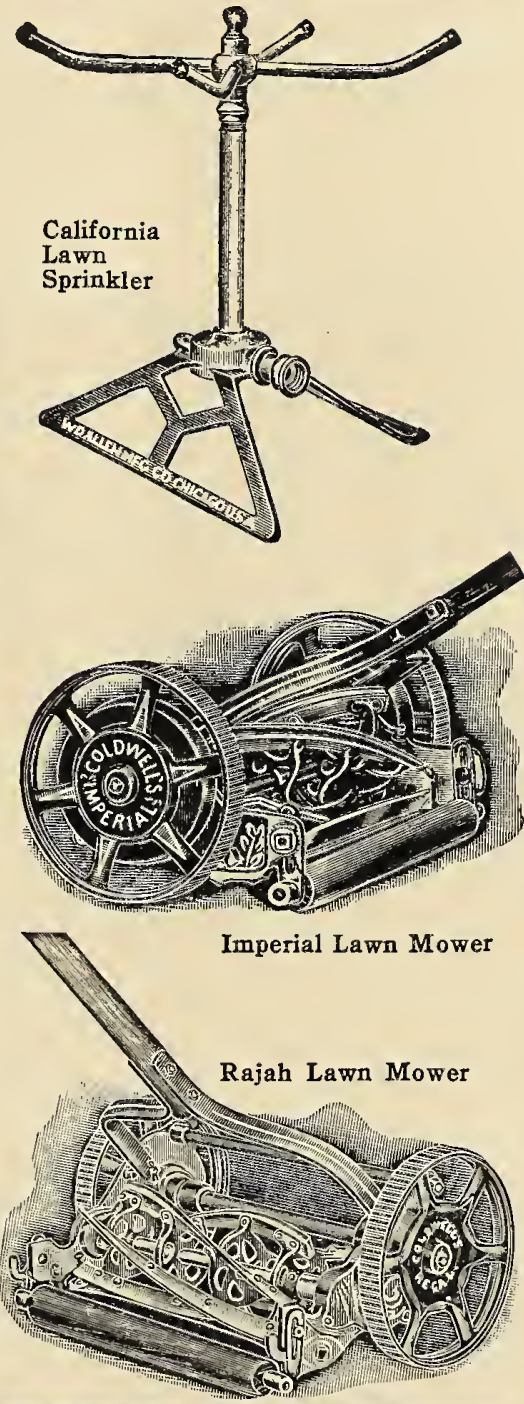

175

175

190

190

200

500

550

65 . |

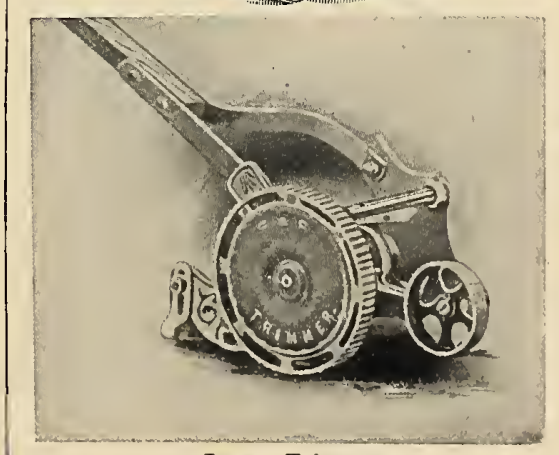

Lawn Trimmer

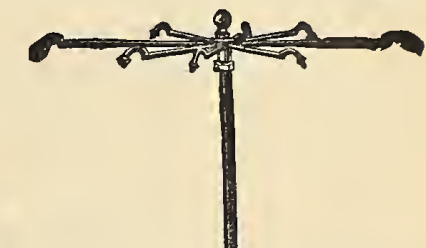

Peck's Lawn Sprinkler

Grass Catcher

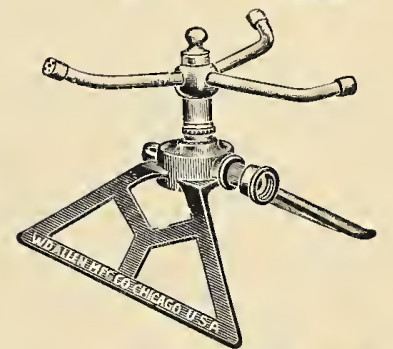

Preston Sprinkler
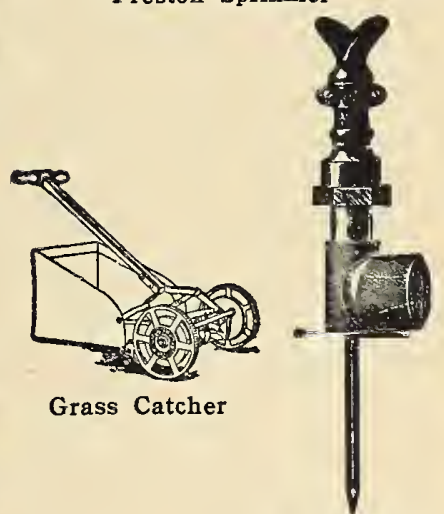

Water Witch

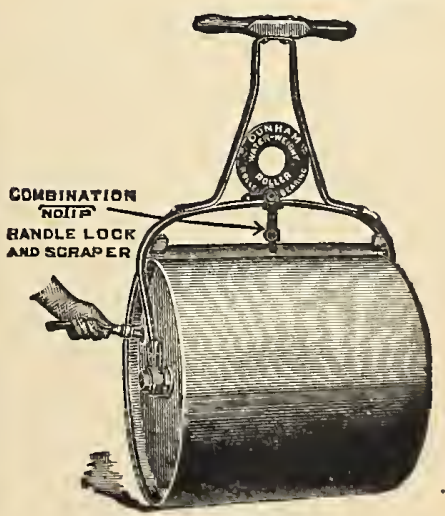

Dunham Roller 


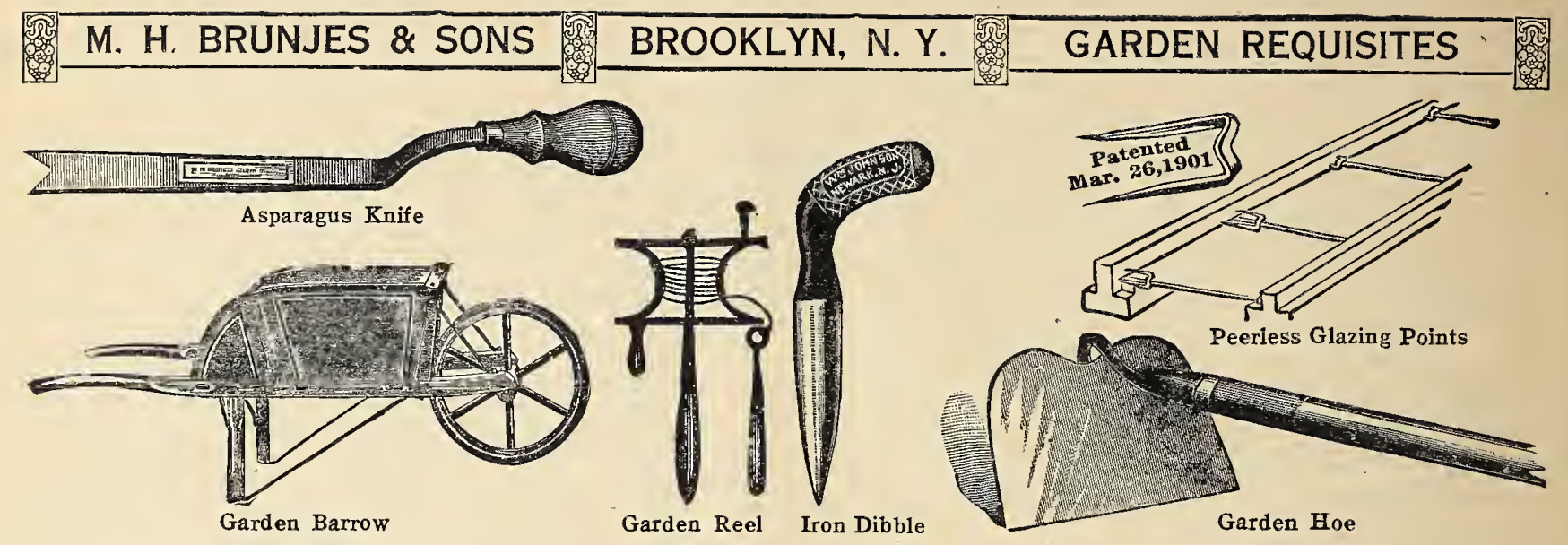

\section{Miscellaneous Garden Requisites}

ASPARAGUS KNIFE, American.............\$ 40

\section{GARDEN BARROWS}

Our Barrows are strong and well made, light but durable, and nicely finisbed. We carry six sizes in stock.

No. 2. Bov's, holding 2 cubic feet.

No. 3. Garden, holding 3 cubic feet...

No. 4. Medrum, holding 4 cubic feet.

No. 4. Hothouse, for greenhouse use.

No. 5. Regular, holding 5 cubic feet

No. 6. Large holding $6 \frac{1}{2}$ cubic feet.

DIBBLES, All-Iron or Wooden Handle. Medium or large.

DIGGER. Post Hole. The blades are 9 inches long and the

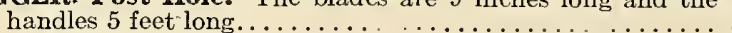

\section{FORKS}

Manure, $\mathrm{D}$ handle, 4 tines, light.

$\mathrm{D}$ handle, 4 tines, regular.

$D$ handle, 5 tines, regular.

$D$ handle, 6 tines, light.

Digging, or Spading. 4 tines, boy's.

4 tines, regular.

4 tines, heavy. .

5 tines.

Hay. Long handle; 2 tines.

3 tines

Stable. Long handle; 4 tines, strapped

FRUIT PICKER, Wire.

GARDEN REELS. .

GARDEN LINE. Best braided....... per $100 \mathrm{ft}$, $\$ 175 \ldots$

GARDEN SETS, For Children (hoe, rake and shovel) $20 \mathrm{c}$. and

For Ladies, well made............................ $\begin{array}{r}35 \\ 75\end{array}$

GLAZING POINTS. Peerless (Improved Van Reyper).

No. 2. For medium double-thick glass. Per box, 1,000, $75 \mathrm{c}$. . by mail, $90 \mathrm{c}$

No. 21/2. For large double-thick glass. Per box, $1,000,75 \mathrm{cts}$. by mail, $90 \mathrm{c}$.

GRAFTING WAX. Per pkg., 15 cts., $25 \mathrm{c}$, and $40 \mathrm{c}$.

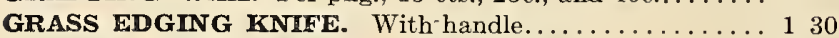

GRASS HOOKS, or SICKLES, FAVORITE. .

English. Riveted back.

Little Giant

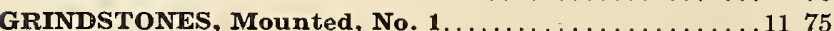

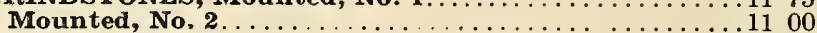

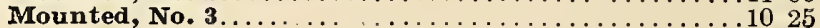

\section{HOES}

Garden, or Field. From 3-inch to 8-inch....... 05 Ladies' 5 -inch........................... 75

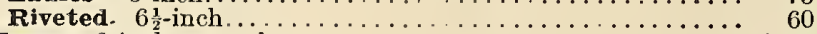

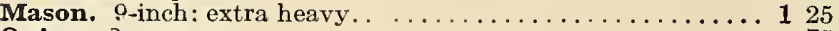

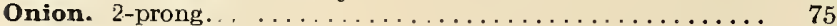

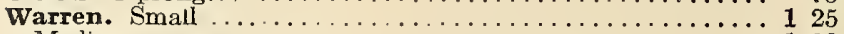
Medium....

Large

Midget. Similar to the above, but with short handle......... 70

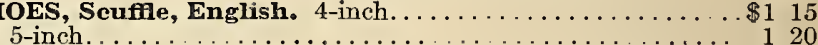

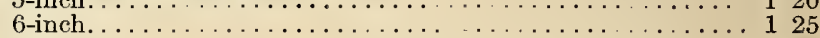

7 -inch........................... 130

HOE and RAKE COMBINED. 4 tine ............ 100

6 tine....................... 110

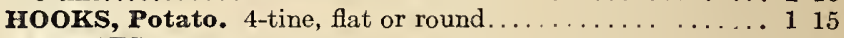

HANDLES, Hoe.

Straight Fork. 5 -foot. . . . . . .

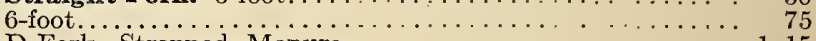

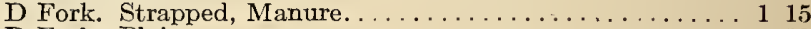

D Fork. Plain........................... 80

\section{RUBBER HOSE}

We can highly recommend the following grades which we have been handling for a good many years. All grades supplied in 25 and 50 -foot lengths and prices include couplings.

Electric. The Electric Hose has corrugated surface, is very light and will not kink. It is largely used by market-Perft. gardeners and florists. $\frac{3}{4}$-inch. 2-ply............. $\$ 022$

Black Snake. $\frac{3}{4}$-inch . . . . . . . . . . . . . . . 19

HOSE COUPLINGS. Brass. $\frac{3}{4}$-inch....... per pair, $30 \mathrm{c} . \ldots$ Each

HOSE ENDS. For attaching to smooth faucets: $\frac{3}{4}$-inch... . . 40

HOSE CLAMP, Bull Dog. Used to fasten around couplings.

Easily applied..................... Doz. $60 \mathrm{c} . \ldots \ldots . \quad 05$

HOSE BANDS. Made of brass wire... Doz. 15c., gross, $\$ 1.35$.

HOSE MENDERS, Cooper's. The best on earth Made of

brass, $\frac{3}{4}$-inch...................... Doz. $\$ 1.25 \ldots$

HOSE WASHERS, Rubber. $\frac{3}{4}$-inch. . . . . . Doz. 8c., lb. $\$ 1 \ldots$

HOSE NOZZLES-

Gem. Throws a spray or solid stream............ 90

Boston. Copper-faced, similar to the rose on a Philadelphia

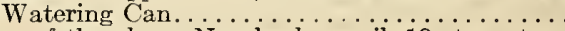

Any of the above Nozzles by mail, 10 ets. extra.

HOSE REELS, Wooden. .

ron. Small; earries 100 feet $\frac{3}{4}$-inch hose $\ldots \ldots \ldots \ldots \ldots \ldots, 500$

Iron. Large; carries 150 feet $\frac{3}{4}$-inch hose.............. 575

JACKS, Wagon, Samson. No. $1 \ldots \ldots \ldots \ldots \ldots \ldots \ldots \ldots 60$

No $2 \ldots \ldots \ldots$

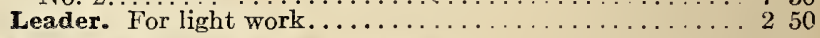

LABELS, Wooden, Pot and Garden- $\quad 100 \quad 1,000$

4 -inch, plain......................\$0 $20 \quad \$ 125$

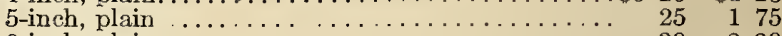

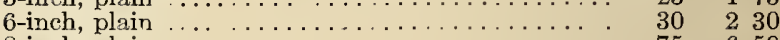

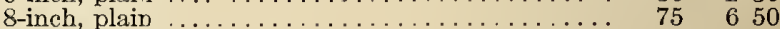

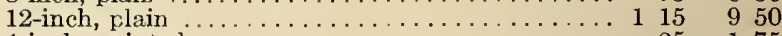

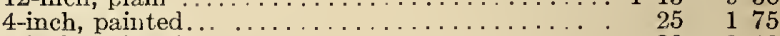

5 -inch, painted $\ldots \ldots \ldots \ldots \ldots \ldots \ldots \ldots \ldots \ldots \ldots \ldots, \quad 30 \quad 2 \quad 10$

6-inch, painted................................ $35 \quad 250$

8-inch, painted......................... $100 \%$

12 -inch, painted................................ $140 \quad 1200$

Copper-Wired. Painted .............. 35 , 300

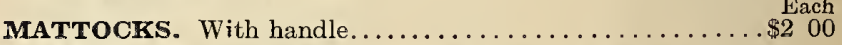

MOLE TRAP, Olmstead. Considered to be the best Mole

Trap on the market today. It is simple and easy to set... 185

OYSTER SHELIS. Crushed......... bag $100 \mathrm{lbs} ., \$ 1.90$. 
Standard Flower Pots, Saucers, Etc. $\begin{array}{llll}\text { Size } & \text { Per doz. } 100 & \text { Size } & \text { Per doz. }\end{array}$ $2 \frac{1}{2}$-inch.......\$0 $30 \$ 200 \mid 8$-inch.............. $\$ 230$ 4 -inch....... $55 \quad 425 \quad 9$-inch............. 370 5 -inch ...... $70 \quad 575 \quad 10$-inch............... 465

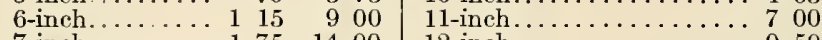

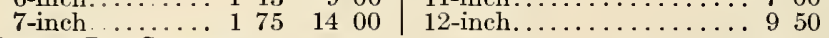

Flower Pot Saucers.

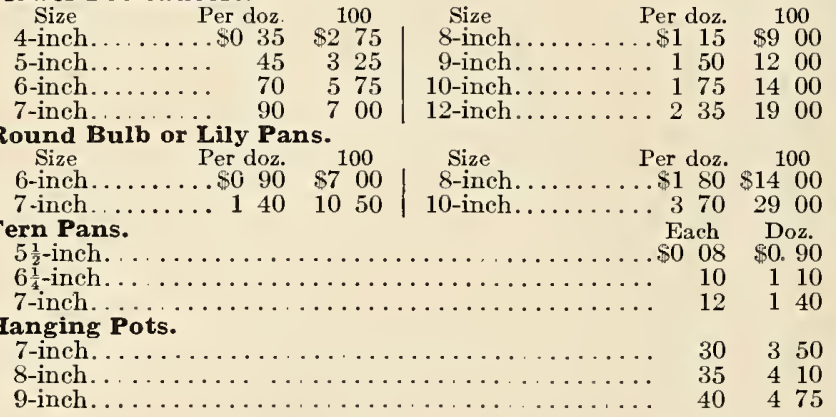

\section{Sprayers and Spray Pumps}

Brunjes' All-Brass Spray Pump. This is one of the strongest Each and most durable bucket pumps for the garden or greenhouse. It has solid brass working parts, a foot rest of malleable iron, 3 feet of hose and combination nozzle which throws a fine or coarse spray and solid stream. It is

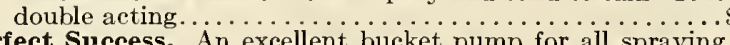

Perfect Success. An excellent bucket pump for all spraying purposes. It is easily operated, may be attached to the pail by means of a patent clamp and is fitted with 3 feet of

hose and Bordeaux Nozzle ........................
Auto-Spray. A simple but well-constructed automatic sprayer, used by innumerable florists, nurserymen and gardeners throughout the country. The auto-pop is a device for controlling the spray. Full directions given with each pump

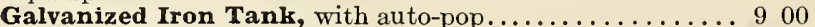

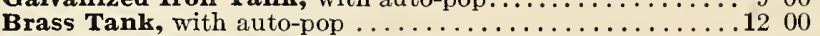

Brass Extension Pipe, 2 feet long..................... 60

Brass Strainer.

Faultless Sprayer. A handy and useful article for small gardens. Holds about one quart. All brass............ 160

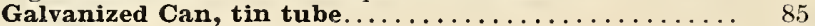

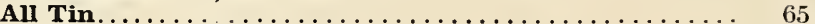

\section{DRY POWDER DUSTERS}

Champion Dry Powder Gun, Leggett's. Each machine is furnished with 4 tubes, 6 nozzles, 2 straps and oil can; will dust two rows of potatoes at a time. Weighs about $6 \mathrm{lbs} . .1300$

Little Giant Powder Gun, Leggett's. Same as the above, only smaller............................ 50 Woodason's. Small single-cone bellows.................. 250

Tin Duster. Used largely for slug shot; holds 2 qts......... 60

Galvanized.

\section{Watering Gans}

6 qts...

8 qts.

Each

$\$ 110 \mid 12$ qts..........

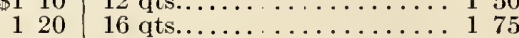

Philadelphia Pattern. Extra heavy, with long spout; each equipped with two copper-faced roses. $6 \mathrm{qts} . \ldots \ldots \ldots \ldots 30$

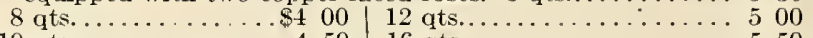
10 qts.......... $450 \quad 16$ qts............ 550

WEEDERS, Eureka. 3 prongs; steel................ 50

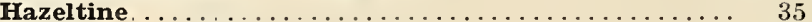

Excelsior. 5 prongs....................... 20

Three-cornered, or Onion................... 55

Forks, Spading...................... 30

Forks. Steel. ...

Daisy. Large or small $\ldots \ldots \ldots \ldots \ldots \ldots \ldots \ldots \ldots \ldots \ldots \ldots \ldots$
Midget. 3 prong. . $\ldots \ldots \ldots \ldots \ldots \ldots \ldots$

WEEDER and CULTIVATOR. One of the easiest-working and most useful hand garden tools on the market. It has 5 prongs and a 4 -foot handle.

All items listed above sent by express or freight at the purchaser's expense

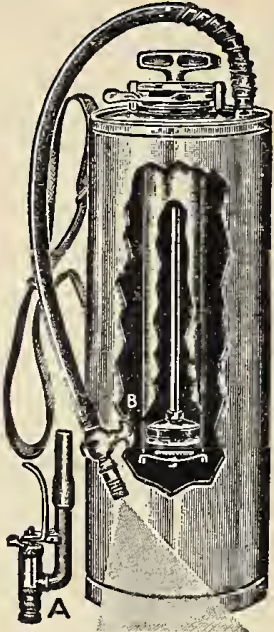

PATENTED.

Auto-Spray

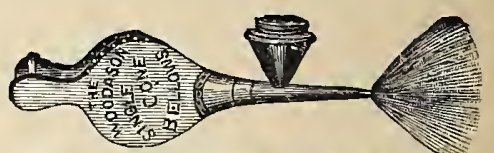

Woodason's Single Cone Bellows
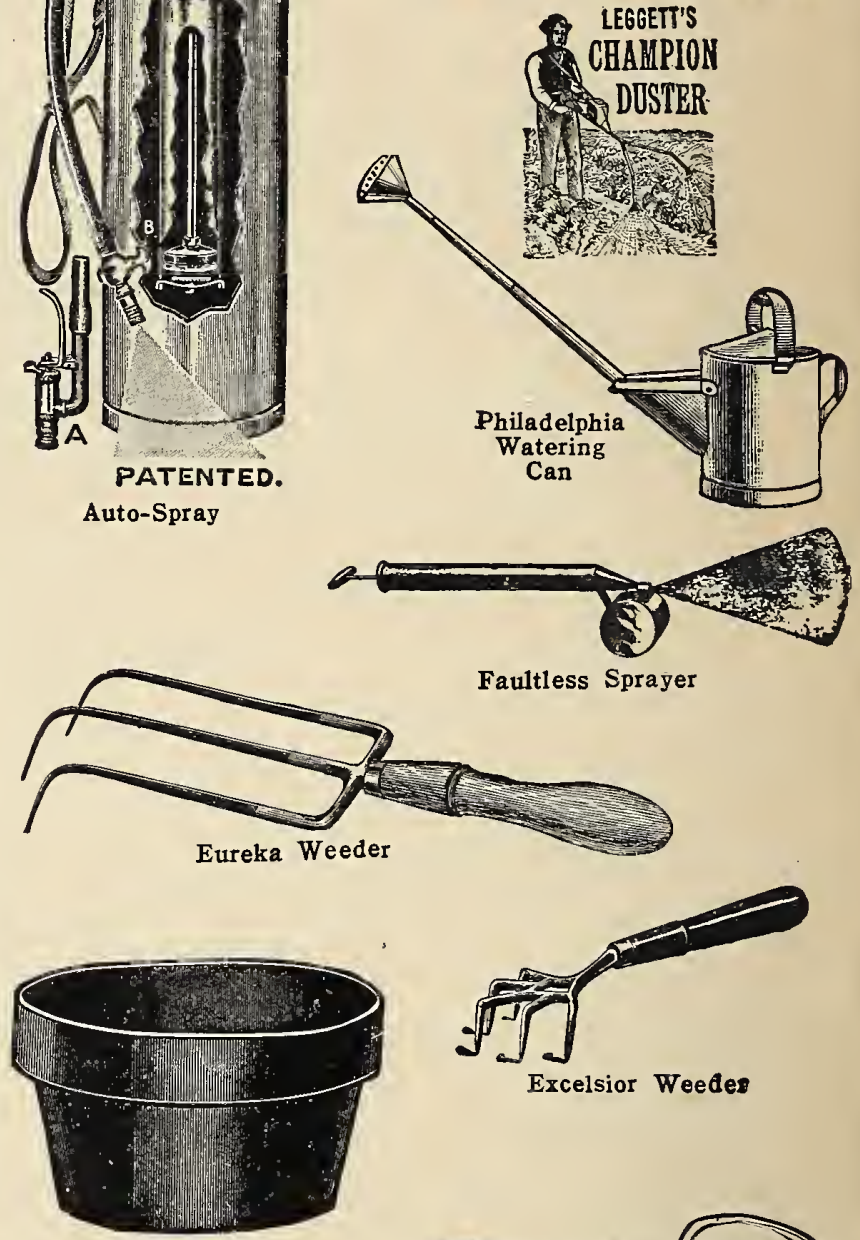

Bulb Pan

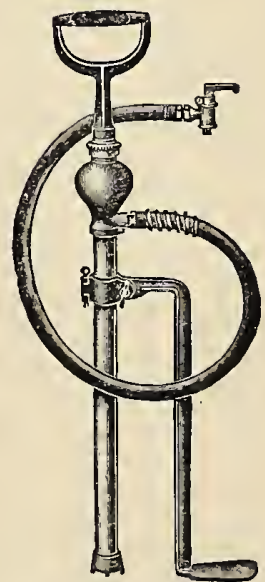

Brunjes' Spray Pump

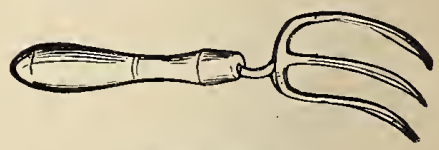

Weeding Fork

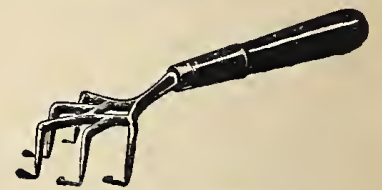

Excelsior Weede?

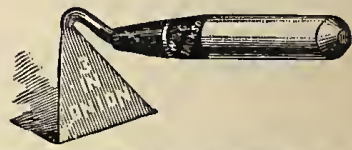

Three-cornered Onion Weeder

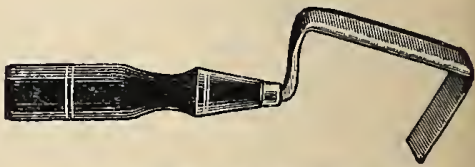

Hazeltine Weeder 


\section{Planet Jr. Farm and Garden Tools}

While there are ever so many users of these well-known labor-saving tools, still there are many gardeners who have yet to know the pleasure of "working with them. They are adapted to all kinds of gardening from the small home garden to the largest and most extensive farm; and, wherever used, the "Planet Jrs." always save time and labor. The tools are strongly made, easily operated, do excellent work, and if not misused will last a long time.

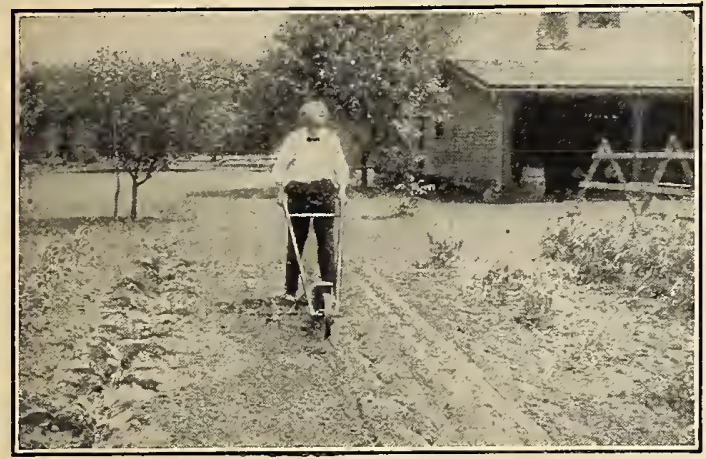

Planet Jr. Seed Drill

\section{"slanet Jr." Hill and Drill Seeders}

No. 3 Hill and Drill Seeder. Similar to but smaller than No. 5. \$21 50 No. 4 Hill and Drill Seeder. One of the best for Market-

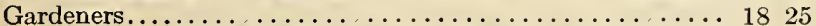

No. 4 Hill and Drill Seeder, Single Wheel Hoe, Cultivator and Plow Combined. In all, this is the handiest and most economical tool for the private or amateur gardener...... 2300

No. 5 Hill and Drill Seeder. Its large size and easy running makes it a favorite with large growers.......... $24 \quad 50$

No. 25 Hill and Drill Seeder, Double Wheel Hoe, Cultivator and Plow Combined. Identical with No. 4 except that this one has a double instead of a single wheel hoe

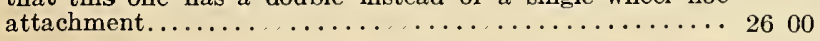

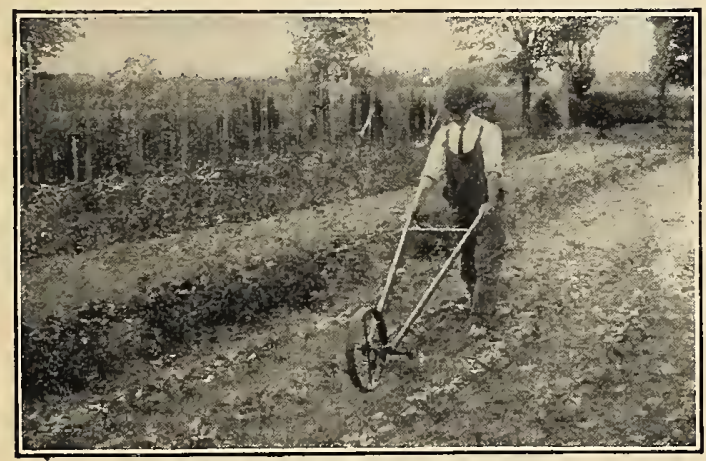

Planet Jr. Single Wheel Hoe

\section{"Planet Jr." Wheel Hoes}

No. 11. Double Wheel Hoe. Highly recommended for private gardens. A complete tool for hoeing, cultivating and

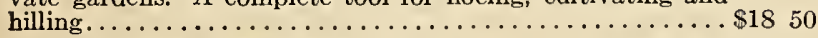

No. 12. Double Wheel Hoe. Has 1 pr. 6 -inch hoes, 2 pr. cultivator teeth, 1 pr. plows, and 1 pr. leaf lifters.........

No. 13. Double Wheel Hoe. Its only attachment is 1 pr.

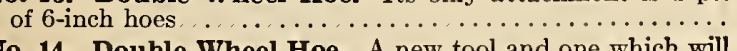
No. 14. Double Wheel Hoe. A new tool and one which will
undoubtedly be found very useful by the market-gardener. undoubtedly be found very useful by the market-gardener.
It has 1 set of disc hoes, 1 pr. 3-prong cultivator teeth, 1 pr. plows and 1 pr. leaf lifters ................... 1650 1500 1050
No. 13 $\frac{1}{2}$. Double Wheel Hoe. Furnished with 1 set of disc hoes and 1 pr. of leaf-lifters. . ................\$13 00

No. 16. Single Wheel Hoe. Attachments include 6-inch hoes, cultivator teeth, rakes, plow and leaf guard........ $12 \quad 25$

No. 17. Single Wheel Hoe. Same as No. 16 but has no rakes

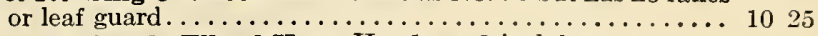
No. 18. Single Wheel Hoe. Has 1 pr. 6 -inch hoes........ 700

No. 19. Farmers' Wheel Hoe, Cultivator and Plow. Distinct from the other single wheel hoes. Has a larger wheel, 3 cultivator steels, 2 shovel steels and a plow ......... 700 "Fire-Fly" Plow $\ldots \ldots \ldots \ldots \ldots \ldots \ldots \ldots \ldots \ldots \ldots, 475$

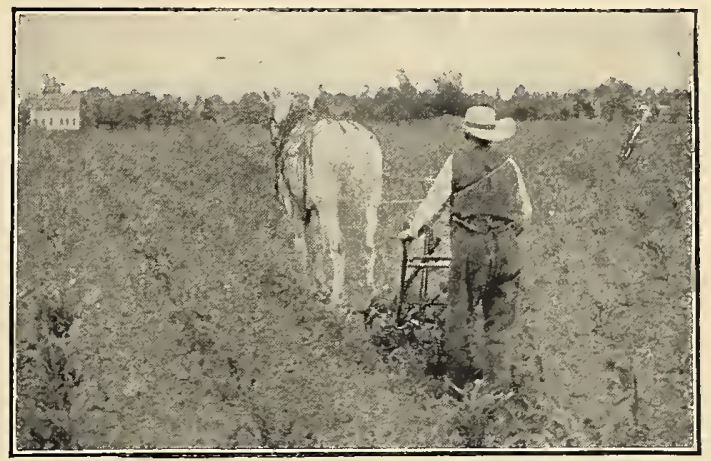

Planet Jr. Horse Hoe and Cu'tivator

\section{"Planet Jr." Horse Hoes and Cultivators}

No. 8 Horse Hoe and Cultivator. This is perhaps the most complete and largely used Horse Hoe .............

No. 7 Horse Hoe and Cultivator. It is practically the same as No. 8 without depth regulator .................. 2325 No. 9 Horse Hoe and Cultivator. The same as No. 7 but has plain wheel instead of lever wheel.................. 2100
Twelve.Tooth Harrow, Cultivator and Pulverizer. Complete. For cultivating and pulverizing it has no equal $\ldots 2450$ Twelve-Tooth Harrow Cultivator. Without pulverizer.... 2075 .

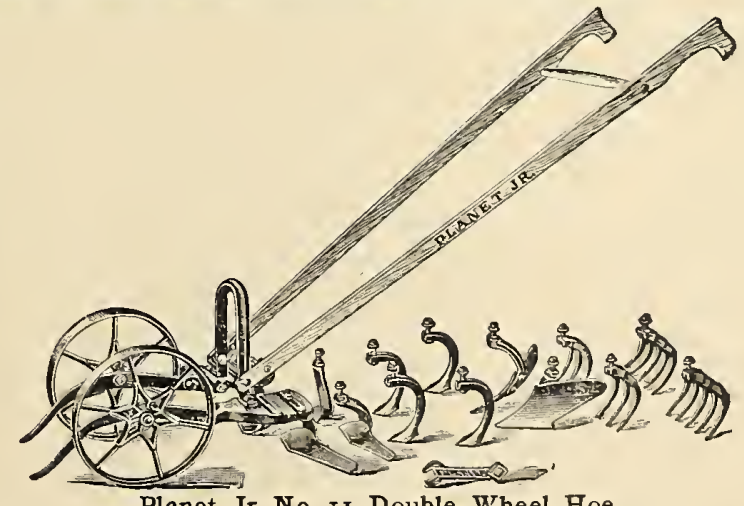

Planet Jr. No. I I Double Wheel Hoe

Planet Jr. Catalogue mailed on request. In sending your orders to us, you can rely on getting bottom prices, and owing to our large stock of their tools shipments can be made promptly. 


\section{Index}

VEGETABLE SEEDS

Artichoke. .

Asparagus . .

Beans

Beet, Spinach

Beet, Sugar. .

Borage.

Broccoli.

Brussels Sprouts

Cabbage

Cabbage, Chinese or Celery, 9, 28

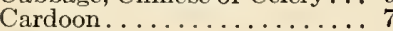

Carrot...

Cauliflower

Celeriac.

Celery

Chard, Swiss

Chervil.

Chicory

Chives.

Citron.

Collards.

Corn Salad.

Corn, Sweet

Cress.

Cress, Water

Cucumber

Dandelion.

Dill

Eggplant.

Endive. .

Fennel.

Garlic. .

Gumbo..................

Herbs, Sweet, Pot and Medic-

inal

Kohlrabi.

Leek.

Lettuce

Mangel-iVurzel

Mushroom Spawn

Muskmelo

Mustard...

Okra.

Onions.

Oyster Plant.

Parsley

Parsnip

Peas..

Pe-Trai .

Potatoes, Seed

Pumpkin.

Radish

Rhubarb.

Romaine.

Rutabaga

Salsify

Scorzonera

Sorrel.

Spinach

Swiss Chard

Tobacco

Tomatoes:

Tirnip

Veretable Plin

Watermelons.............

\section{FARM SEEDS}

Bird Seed

Buckwheat.

Clover.

Corn, Field

Grass Seed

Millet.

14,28

$15,16,28$

.6

17

.16

.19

18,19

.24

20

20,28

9
19

192

.23

.27

24

.24

.24

25

.25

28

28

17

西

.28

.28

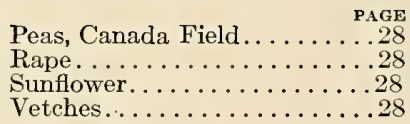

\section{FLOWER SEEDS}

Abronia................. 30

Abutilon................30

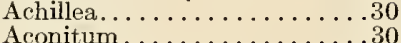

Aconitum............. 30

Adlumia..................30

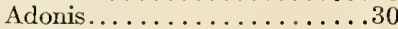

Ageratum.................. 30

Agrostemma..............30

Aloysia . . . . . . . . . . . . 53

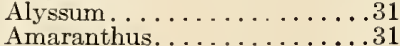

Ammobium. . . . . . . . . . . 31

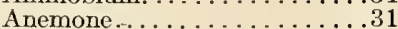

Antirrhinum.......................

Apple, Balsam...........44

Aquilegia................31

Arabis.........................

Arctotis ................

Asparagus..............34

Asters ...........32-34, 52

Baby's Breath ............. 41

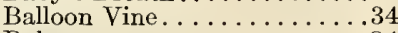

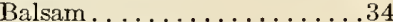

Bean, Hyacinth. . . . . . . . . . 39

Begonia, Fibrous-rooted...... 34

Bellflower.................35

Bellis. ........................

Butterfly Flower..............

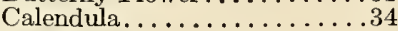

Calceolaria ..............35

Calliopsis.....................

Campanula....................

Campion, Rose.............. 30

Canary-Bird Flower........52

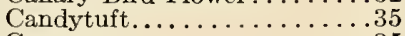

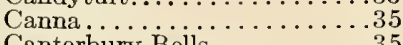

Canterbury Bells..........35

Cardinal Climber........... 38

Carnation ..................

Castor-Oil Bean..............50

Celosia .................. 36

Centaurea............36,52

Cheiranthus .......... 53,58

Cherry, Jerusalem...........52

Chrysanthemum . . . . . . . .36

Cigar Plant.............. 38

Cineraria................... 37

Clarkia.

Cleome.

Cobæa.

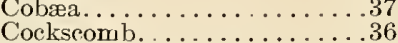

Coleus. ................37

Collection of Popular Flowers. 54

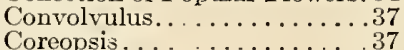

Cornflower..............36

Cosmos ...........................

Cucumber Vine, Wild........41

Cup-and-Saucer...........35

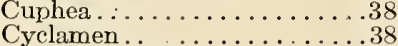

Cypress, Summer...........42

Cypress Vine $\quad \ldots . .33$

Dahlia African Golden..........39 38

Daisy, Double .. . . . . . . 39

Datura

Delphinium

Devil-in-a-Bush. ........45, 50

Dianthus. . . . . . 45, 50

Digitalis

Dimorphothe ${ }^{2} \ldots \ldots \ldots \ldots .39$

Dolichos.

Dracæna.
Dusty Millers............ ${ }^{\text {PAGE }}$

Echinocystis..................

Eschscholtzia...............40

Eschscholtzia, Bush..........42

Euphorbia..............41

Feverfew................. 43

Fire Plant.............51

Flax................ 43

Forget-me-not. . . . . . . . .44

Four-o'Clock. . . . . . . . . .

Foxglove .............. 39

Fringe, Mountain. . . . . . . . 30

Gaillardia..............41

Geranium..................

Globe Amaranth..........41

Godetia................41

Gomphrena................

Gourds...................

Grasses, Ornamental.......41

Gypsophila.............41

Helianthus. . . . . . . . . .

Helichrysum............. 41

Heliotrope..............41

Hesperis . . . . . . . . . . . 52

Hollyhock. . . . . . . . . 42

Hop, Japanese . . . . . . . . . . .42

Horn of Plenty . . . . . . . . . . 39

Humulus...............42

Hunnemannia. . . . . . . . . 42

Iberis............... 35

Ice Plant.............42

Impatiens. . . . . . . . . . 42

Ipomœa............. 38,42

Ivy, Kenilworth. . . . . . . . . 43

Jacobæa . . . . . . . . . . . . 42

Joseph's Coat. ............. 31

Kochia..............42

Lady's Slipper...........34

Lantana ...... Chinese . . . . . . .47

Larkspur............... 39

Lathyrus... . . . . . . . . 46

Linaria . . . . . . . . . . 43

Linum. . . . . . . . . . . . 43

Lobelia. . . . . . . . . . . . 43

Lophospermum . ............43

Love-in-a-Mist ............ $\ldots 45$

Love-Lies-Bleeding . . . . . . . . . 31

Lupinus...............43

Lychnis...................

Malope................43

Marigolds ............ 34, 44

Marvel of Peru. . ........ .44

Matricaria............... . 43

Matthiola. . . ..........43

Mesembryanthemum .... . . 42

Mignonette.............44

Mimosa...................

Mimulus . . . . . . . . . . . . 44

Momordica..............44

Monkey Flower. . . . . . . . . .

Moonflower. . . . . . . . . 42

Morning-Glory...... . . . . . .37

Mourning Bride............ . . .

Musk Plant............... 44

Myosotis..............4. 44

Nasturtiums.... . . . . . . .45

Nemesia.

Nemophila

Nicotizna

Nigella.....

Enothera. .

Pansies

Pansies, Tufted

Peach Bells... .

Pear, Balsam.

Peas, Perennial

Peritstemon.

Periwinkle.

Petunia.

Phlox $\ldots \ldots \ldots \ldots \ldots \ldots \ldots .49$

Physalis...................

Pinks...................

Platycodon.............53

Poppies..............48

Poppy, California . . . . . . 40

Portulaca..............50

Primrose, Evening.........45

Primrose, Chinese . . . . . . . . . . 49

Primula................. 49

Pyrethrum .................

Red-hot Poker Plant. . . . . . .52

Reseda................44

Rhodanthe............... 50

Ricinus...............50

Rose of Heaven. . . . . . . . . 30

Rudbeckia............... . . 50

Salpiglossis. . . . . . . . . . 51

Salvia ................. 51

Sanvitalia.............51

Scabiosa...............

Schizanthus.............

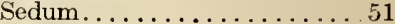

Sensitive Plant..............

Smilax.................52

Snapdragon.............. 31

Snow-on-the-Mountain.......41 


\section{ORDER SHEET FOR SEEDS, BULBS, PLANTS, ETC.}

\section{H. BRUNJES \& SONS}

\section{MYRTLE AVE., BROOKLYN, N. Y.}

M. H. Brunjes \& Sons give no warranty, express or implied, as to description, quality, productivness, or any other matter of any seeds, bulbs or plants we send out, and we will not be in any way responsible for the crop. If the purchaser does not accept the goods on these terms, they are at once to be returned.-M. H. B. \& Sons.

VERY IMPORTANT - Write your name very plainly in black ink, and give your post office, county and state in full every time.

Forward by

Slale on above line whather wanted by Mail, Express or Freight

Name...........

Street Address

Post Office

County

P. O. Box

R.F.D. No.

State

Exp. or Freight Office

\section{AMOUNT ENCLOSED}

P. O. Order . . \$.

Express Order . . \$.

Draft . . . \$.

Cash . . . \$.

Regist'd Letter . \$.

Post. Stamps . .

(2c stamps preferred)

Total . . \$.

\section{QUANTITY}

From

P. 0 .
NAMES OF ARTICLES WANTED

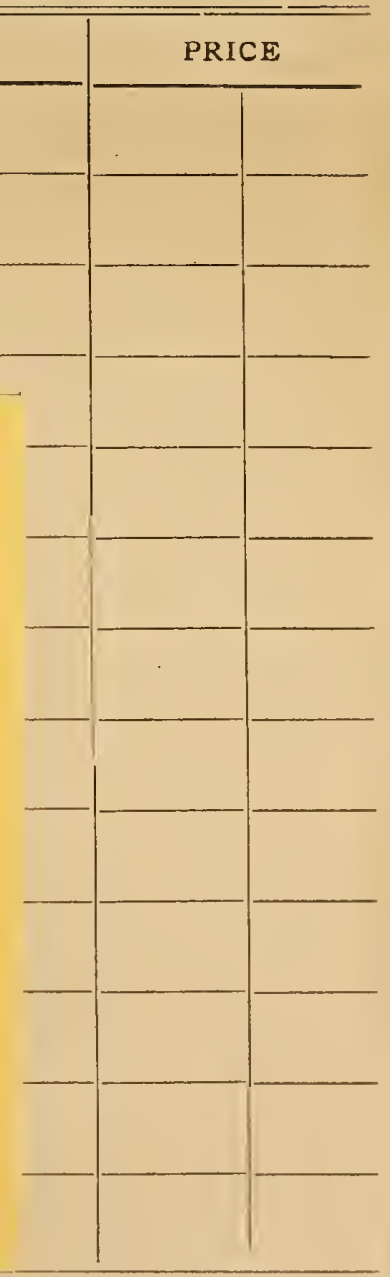

\section{H. BRUNJES \& SONS}

\section{Reliable Seeds, Bulbs, Plants




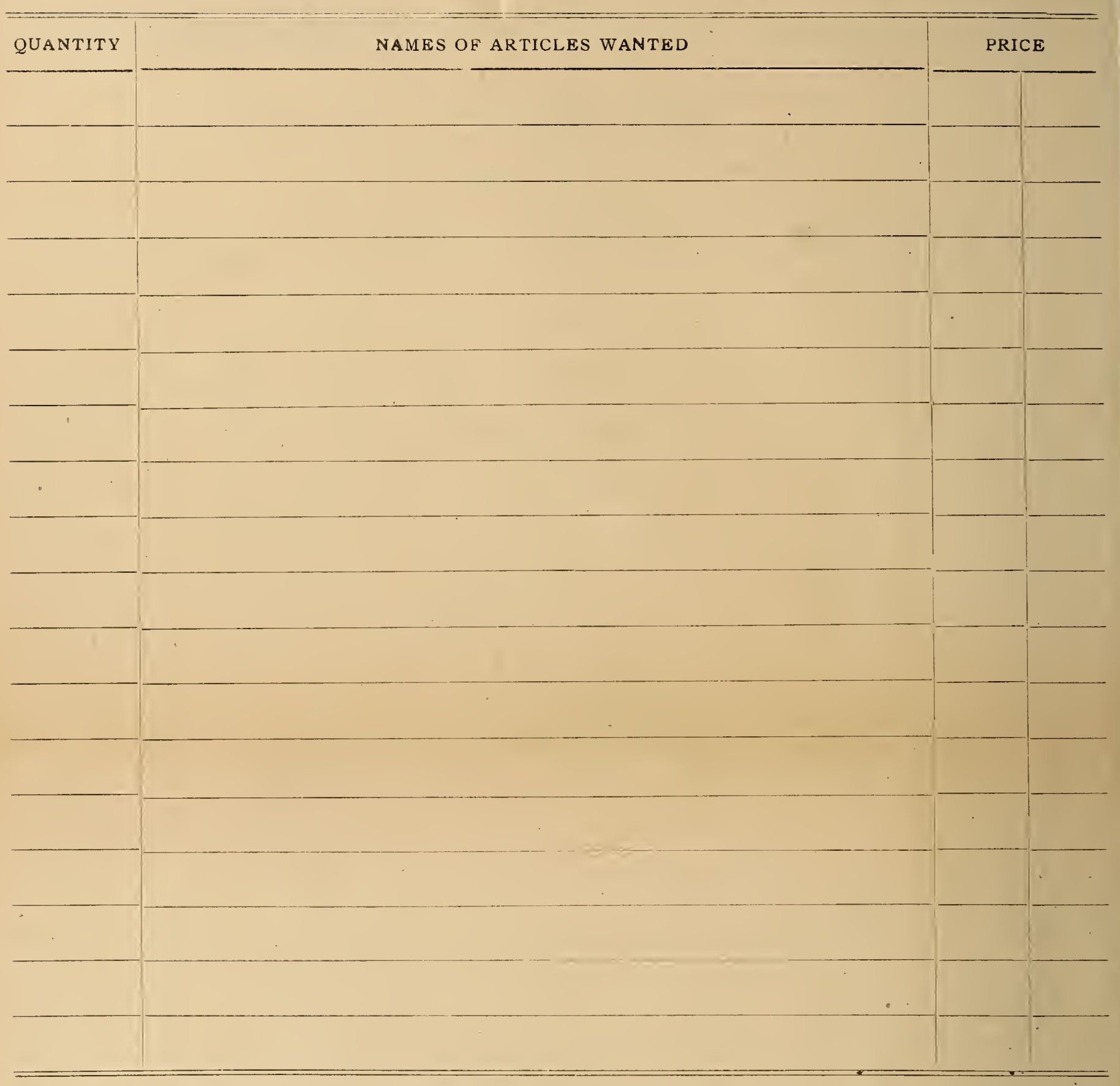

WRITE HERE ANY FURTHER INSTRUCTIONS REGARDING THIS ORDER 
Liquids and poisonous powders are not mailable and can be sent by express only, at purchaser's expense

Ant-I-Cide. A powder to be sprinkled on the ground against square feet. Lb. $30 \mathrm{cts}$.

Arsenate of Lead (Paste). Kills caterpillars and all leafnot wash off or burn the tenderest foliage. Apply at the rate of from 2 to 3 pounds to 50 gallons of water. Lb. 40 cts., 5 lbs. $\$ 1.75$.

Arsenate of Lead (Powdered). Has all the advantages of Arsenate of Lead Arsenate of Lead paste, hut goes twice as far, and is easier to handle. Dilute 1 pound to 50 gallons of water. Lb. 60 ets., 5 lbs. $\$ 2.75,10$ lbs. $\$ 5,25$ lbs. $\$ 11.50$.

Bordeaux Mixture. For all fungous diseases such as rust, Bordeaux Mixture. potato blight,-nildew and various rot of grapes. Use one quart to 49 quarts of water. Pt. 35 ets., qt 65 cts., gal. $\$ 1.85,5$ gals. $\$ 7.50$.

Cut-Worm Killer. A coarse powder for sprinkling near the will plants to be protected. Chickens or birds Grape Dust, Hammond's. Used for mildew and rust on either in the garden or greenhouse. 5 -lb pkg. 85 cts.

Hellebore. One of the best insecticides for the garden, especially cellebore. for roses, currants and other small fruits. Apply with bellows or in water-one ounce of Hellebore to two gallons of water. $\frac{1}{4}$ lb. 20 ets., $\frac{1}{2}$ lb. 35 cts., lb. 65 cts.

Lime-Sulphui Solution. The best mixture for San José ime-Sulphur Solution. and other seale on trees and shrubs. Directions on can. Qt. 40 cts., gal. $\$ 1,5$ gals. $\$ 4.75$

Bordeaux-Arsenate of Lead Mixture. Especially good also good for roses, keeping them free of mildew and insects of all sorts. Spray early in spring. Pt. 40 cts., qt. 75 cts., gal. $\$ 2.25$.

Black Leaf 40. A powerful insecticide and when used as a spray, the attacks of insects. One ounce to 6 gallons of water is the proper
Black Leaf 40, continued

spraying solution. Highly recommended for the rose bug, greenfly, plant lice, aphis, ete. 1 -oz. bottle 25 cts., $\frac{1}{2}$-lb tin $\$ 1,2$ lbs. $\$ 3.25$.

Paris Green. A poisonous powder largely used to kill potato aris Green. bugs, caterpillars, ete. Can be used either dry quarts of water. $\frac{1}{2}$ lb. 40 cts., lb. 70 cts., 5 lbs. $\$ 3,14$-lb. pail $\$ 8$.

Pyrox. A sure remedy for all leaf-eating insects and largely used - for spraying fruit trees, shrubs, grape-vines, curran roses, potatoes, cucumbers, etc. A combined insecticide and fungicide which should be mixed with cold water. Lb. 45 cts. 5 lbs. $\$ 1.90,10$ lbs. $\$ 3.25$.

Scalecide. The best spray for San José scale and all other kinds lon to 20 gailons of cold water and spray either in late fall, winter, or early spring, while the foliage is off. Qt. 65 ets., gal. $\$ 1.60$, 5 gals. $\$ 6.80,10$ gals. $\$ 11.70$.

Slug-Shot, Hammond's, A non-poisonous insecticide used and currant worm, rose and plant lice, good results for the cabbag Lb. 20 cts., 5 lbs. 60 cts., 10 lbs. $\$ 1,25$ lbs. $\$ 2.50,100$ lbs. $\$ 9.50$.

Sulpho-Tobacco Soap. Exterminates all insects on plants also acts as a fertilizer. 3 -oz. box 15 cts., 8 -oz. box. 25 cts.

Tobacco Dust. A sure remedy for plants affected with lice, $5 \mathrm{lbs} .35 \mathrm{cts}, 10 \mathrm{lbs} .60$ ets., $50 \mathrm{lbs} . \$ 2.25,100 \mathrm{lbs}$. $\$ 4$.

Fish-Oil Soap. A reliable insecticide for general use. It is easily Soap. applied to trees, plants and vines whether for scale or other destructive insects. Lb. box 30 cts., 5 lbs. $\$ 1.35$.

Weedicide. For keeping walks, drives and tennis-courts free from from 10 to 20 parts of water. Qt. 50 cts., gal. $\$ 1.50,5$ gals. $\$ 7$.

\section{FERTILIZERS}

\section{Bone Meal}

One of the best fertilizers for the lawn, encouraging a luxuriant dark green growth, especially if applied before a rain. Equally good cither for pot-plants or rose and carnation-culture. Results are obtained quickly from its use. Lb. 10 cts.. $10 \mathrm{lbs} .65 \mathrm{cts}, 20 \mathrm{lbs} . \$ 1.25$, 50 lbs. $\$ 2.25,100$ lbs. $\$ 4,500$ lbs. $\$ 19$, ton $(2,000$ lbs. $) \$ 70$

\section{Bowker's Food for Flowers}

The use of this fertilizer will certainly repay the user many times, hoth in size and number of flowers, besides giving the foliage a rich, green, healthy color. A large package is sufficient for 30 plants for 6 months. Small pkg. 30 cts. (weight $\frac{1}{2} 1 \mathrm{~b}$.); large pkg. 50 ets. (weight $1 \mathrm{lb}$. .). Add postage at zone rates.

\section{Nitrate of Soda}

Should be applied only to crops above ground, and as it is very strong, should not be used carelessly. It acts quickly and hastenis maturity of flowers, fruits, and vegetables at least two weeks. Write for price.

\section{Sheep Manure}

When mixed with soil or used as a liquid fertilizer, it is very beneficial to all plant life, whether in the greenhouse or garden. Although not so quick in action as some fertilizers, it is more lasting and insures a continuous, steady growth. Lb. 15 ets., 5 lbs. 45 ets., 10 lbs. 80 cts., 20 lbs. $\$ 1.25,50$ lbs. $\$ 2.25$, bag (100 lbs.) $\$ 4$, ton $\$ 65$.

\section{Mapes' Fertilizers}

These standard fertilizers have been on the market for a good many years and owing to the good results obtained from their use have become popular everywhere, as all who have used them will do so again. They are composed mainly of ground bone, no rock being used, and can be applied easily by machine or hand.

General Crop. (1916 Brand.) An excellent fertilizer for general use in the vegetable-garden. It will be found a good substitute for stable manure, and is not only cleaner but much easier to handle. If the soil is in fairly good condition, 100 pounds will be sufficient for a plot $25 \times 100$ feet. Lb. 10 cts., 5 lbs. 35 cts., 10 lbs. 65 cts., 20 lbs. $\$ 1.25,50$ lbs. $\$ 2.25$, bag (100 lbs.) $\$ 3.75,500$ lbs. $\$ 17$, ton $(2,000$ lbs. $) \$ 60$.

Potato Manure. This is a complete manure for potatoes, re quiring the addition of neither stable manure nor any other fertilizer. It is also well adapted for all vegetables. For potatoes use from 600 to 1,000 pounc's to the acre, according to the fertility of the soil, and mix thoroughly. Bag (100 lbs.) $\$ 4.75,500$ lbs. $\$ 22$, ton $(2,000$ lbs. $) \$ 80$.

\section{Agricultural Lime}

This is an efficient agent to correct soil acidity. For vegetables, flowers, and grass use about 1 pound of agricultural lime to 20 square feet of soil. Sprinkle evenly over the ground and work it into the surface of the soil with a hand rake. Can be applied any time of the year without danger. 5 lbs. 30 cts., 10 lbs. 45 cts., 25 lbs. 80 ets., 50 lbs. $\$ 1.25,100$ lbs. $\$ 2$. 


\section{Brunjes' Reliable Seeds AND BULBS}

M.H.BRUNJES \& SONS 1581 MYRTLE AVENUE BROOKLYN, N.Y.

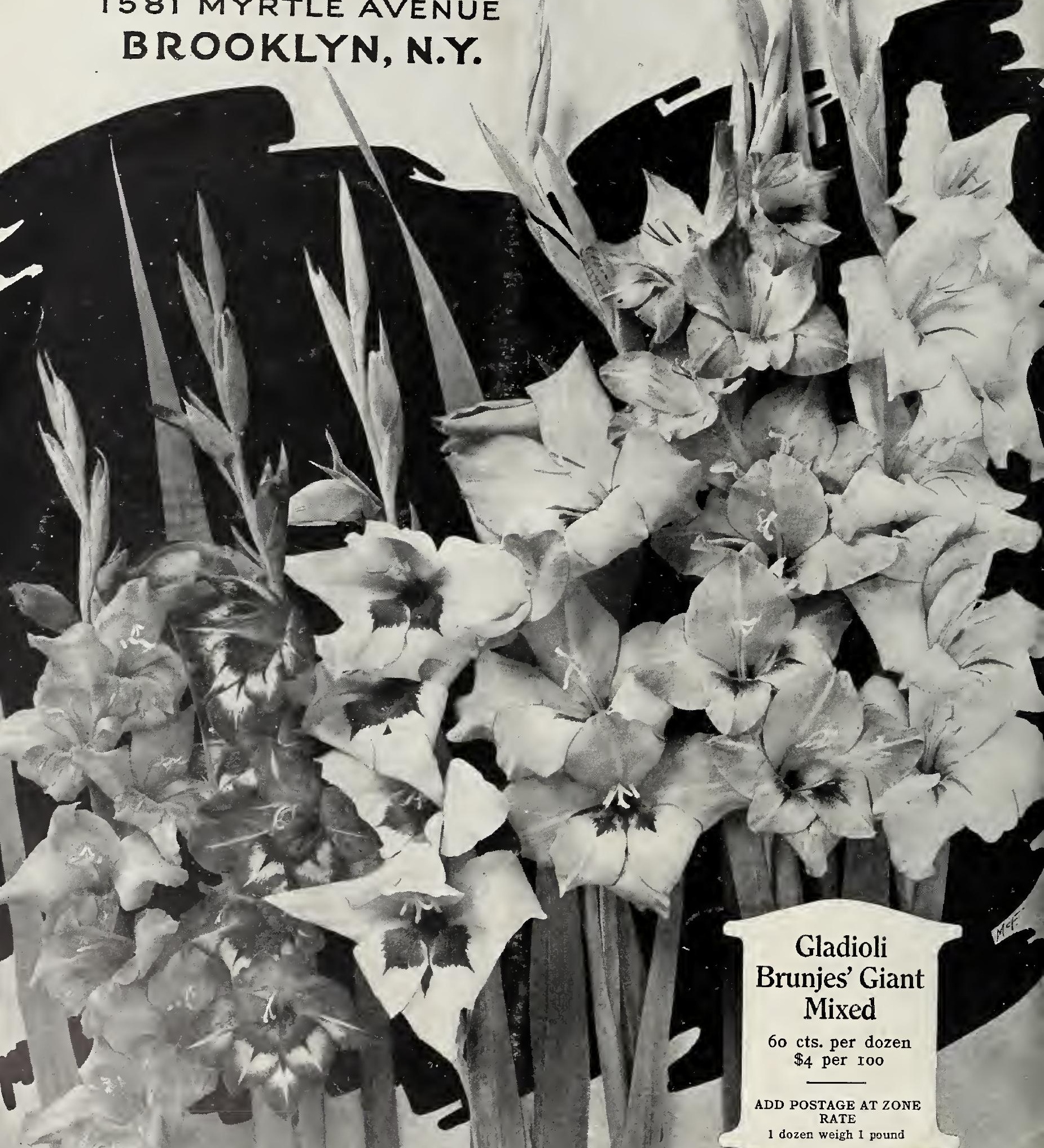

